US Army Corps

of Engineers

Waterways Experiment

Station

\title{
Navigation Conditions at Bonneville Locks and Dam, Columbia River
}

by Ronald T. Wooley 
The contents of this report are not to be used for advertising, publication, or promotional purposes. Citation of trade names does not constitute an official endorsement or approval of the use of such commercial products.

The findings of this report are not to be construed as an official Department of the Army position, unless so designated by other authorized documents. 


\section{Navigation Conditions at Bonneville Locks and Dam, Columbia River}

by Ronald T. Wooley

U.S. Army Corps of Engineers

Waterways Experiment Station

3909 Halls Ferry Road

Vicksburg, MS 39180-6199

Final report

Approved for public release; distribution is unlimited

Prepared for U.S. Army Engineer District, Portland

Portland, OR 97208-2946 


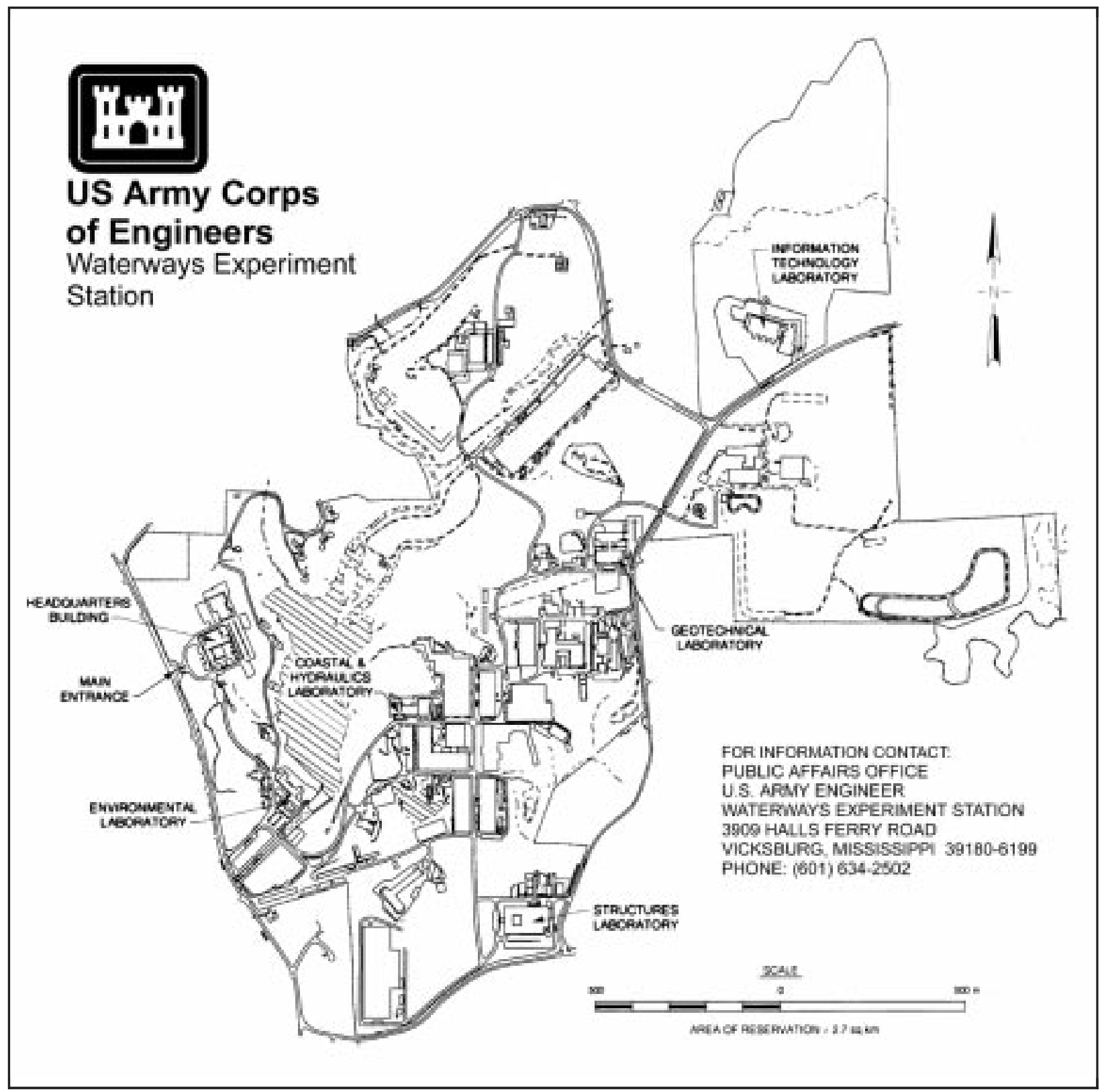

Waterways Experiment Station Cataloging-in-Publication Data

Wooley, Ronald T.

Navigation Conditions at Bonneville Locks and Dam, Columbia River / by Ronald T. Wooley ; prepared for U.S. Army Engineer District, Portland.

207 p. : ill. ; $28 \mathrm{~cm}$. - (Technical report ; CHL-98-6)

Includes bibliographic references.

1. Inland navigation - Columbia River. 2. Locks (Hydraulic engineering) - Columbia River.

3. Navigation - Columbia River. I. United States. Army. Corps of Engineers. Portland District. II. U.S. Army Engineer Waterways Experiment Station. III. Coastal and Hydraulics Laboratory (U.S. Army Engineer Waterways Experiment Station) IV. Title. V. Series: Technical report (U.S. Army Engineer Waterways Experiment Station) ; CHL-98-6. TA7 W34 no.CHL-98-6 


\section{Contents}

Preface ...................... vi

Conversion Factors, Non-SI to SI Units of Measurement . . . . . . . . . . vii

1-Introduction . . . . . . . . . . . . . . . . . . . . . . . 1

Location and Description of Prototype $\ldots \ldots \ldots \ldots$

Existing Conditions $\ldots \ldots \ldots \ldots \ldots \ldots \ldots$

Present Development Plan _. . . . . . . . . . . . . 3

Need for and Purpose of Model Study $\ldots \ldots \ldots$. . . . . . . . 4

2-The Model . . . . . . . . . . . . . . . . . . . 5

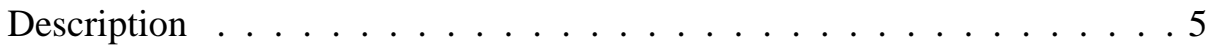

Scale Relations . . . . . . . . . . . . . . . . . 5

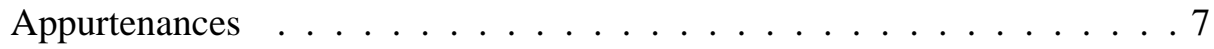

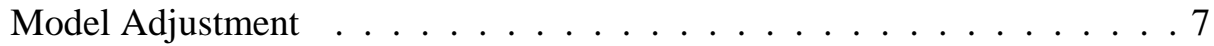

3-Experiments and Results . . . . . . . . . . . . . . . 8

Experiment Procedures . . . . . . . . . . . . . . . . 8

Base Experiments with Existing Conditions . . . . . . . . . . 10

Experiments with Original Design . . . . . . . . . . . . . . . 17

Experiments with Plans A through A-3 . . . . . . . . . . . . . 22

Experiments with Plans B through B-2 . . . . . . . . . . . . . . . . . 29

Experiments with Plans C through C-9 . . . . . . . . . . . . . 34

Experiments with Plan D . . . . . . . . . . . . . . . . . 46

Experiments with Plan D-1 . . . . . . . . . . . . . . . . . . . . . . . 49

Experiments with Plan D-2 . . . . . . . . . . . . . . . 51

Experiments with Plan E . . . . . . . . . . . . . . 53

Experiments with Plan $\mathrm{F} \ldots \ldots \ldots \ldots \ldots$

Experiments with Plan F-1 f . . . . . . . . . . . . . 61

4-Discussion of Results and Conclusions _ . . . . . . . . . . . . 68

Limitation of Model Results . . . . . . . . . . . . . . . . . . 68

Summary of Results and Conclusions _ . . . . . . . . . . . . . 68

Tables 1-18

Photos 1-12 
Plates 1-144

SF 298

\section{List of Figures}

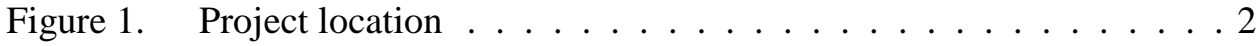

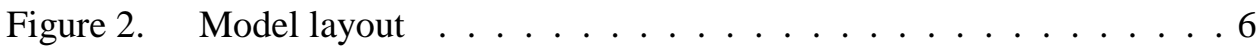

Figure 3. Existing structures, looking upstream from left to right second powerhouse, spillway, first powerhouse, and existing lock . . . . . . . . . . . . . 11

Figure 4. Plan and sections, existing lock and first powerhouse . . . . . 12

Figure 5. Downstream view showing existing lock and first powerhouse ..................... 13

Figure 6. Downstream view showing gated spillway . . . . . . . . . . . 14

Figure 7. Downstream view showing second powerhouse . . . . . . . 15

Figure $8 . \quad$ Original design $\ldots \ldots \ldots \ldots$

Figure 9. Plan and sections, new lock . . . . . . . . . . . . . . . . . 19

Figure $10 . \quad$ Surge stations $\ldots \ldots \ldots . \ldots \ldots$

Figure 11. Plan A . . . . . . . . . . . . . . . . . . . . 24

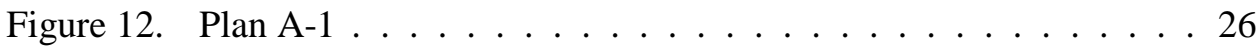

Figure 13. Plan A-2 . . . . . . . . . . . . . . . . 27

Figure 14. Plan A-3 . . . . . . . . . . . . . . 28

Figure 15. Plan B ...................... 30

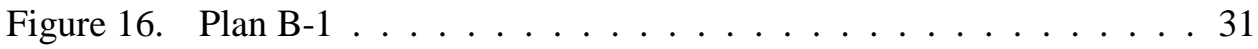

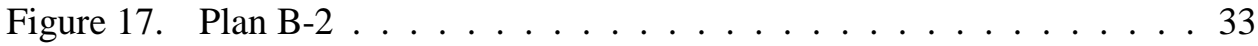

Figure 18. Plan C . . . . . . . . . . . . . . . 35

Figure 19. Plan $\mathrm{C}-1 \ldots \ldots \ldots \ldots$. . . . . . . . . . . . . . . . . .

Figure 20. Plan $\mathrm{C}-2 \ldots \ldots \ldots$. . . . . . . . . . . . . . . . . . . . .

Figure 21. Plan $\mathrm{C}-3 \ldots \ldots \ldots$. . . . . . . . . . . . . . . . . . . . .

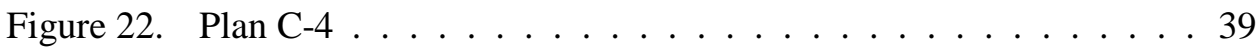

Figure 23. Plan $\mathrm{C}-5 \ldots \ldots \ldots$. . . . . . . . . . . . . . . . . .

Figure 24. Plan C $6 \ldots \ldots$. . . . . . . . . . . . . . . 41

Figure $25 . \quad$ Plan $\mathrm{C}-7 \ldots \ldots \ldots 4 \ldots \ldots \ldots$

Figure $26 . \quad$ Plan $\mathrm{C}-8 \ldots \ldots \ldots \ldots$. . . . . . . . . . . . . . . . . . 
Figure 27. Plan C $-9 \ldots \ldots$. . . . . . . . . . . . . . . . . . . . 44

Figure 28. Plan D . . . . . . . . . . . . . . . . 47

Figure 29. Plan D-1 . . . . . . . . . . . . . . . . . 50

Figure $30 . \quad$ Plan D-2 . . . . . . . . . . . . . . 52

Figure 31. Plan E . . . . . . . . . . . . . . . 54

Figure 32. Plan $\mathrm{F} \ldots \ldots \ldots \ldots 6$

Figure 33. Plan F, plan and section, floating guard wall . . . . . . . 57

Figure 34. Plan F-1 . . . . . . . . . . . . . . . 63

Figure 35. Plan F-1, plan and section of floating guard wall . . . . . . . 64 


\section{Preface}

This model investigation was conducted for the U.S. Army Engineer District, Portland, and authorized by DA Form 2544, Order No. E86820108, dated 8 March 1982, to the U.S. Army Engineer Waterways Experiment Station (WES), Vicksburg, Mississippi. The study was conducted in the Hydraulics Laboratory of WES during the period March 1982 to April 1992.

During the course of the model study, representatives of the Portland District and other navigation interests visited WES at different times to observe special model experiments and to discuss the results of those experiments. The Portland District was informed of the study's progress by monthly reports and special presentations at the conclusion of each experiment.

This report is being published by the WES Coastal and Hydraulics Laboratory (CHL). The CHL was formed in October 1996 with the merger of the WES Coastal Engineering Research Center and the Hydraulics Laboratory. Dr. James R. Houston is the Director of the CHL, and Mr. Charles C. Calhoun, Jr., is Assistant Director.

The first-line review of this report was conducted by Mr. T. J. Pokrefke, Acting Chief of the Navigation Division, CHL. The principal investigator in immediate charge of the model study was Mr. R. T. Wooley, assisted by Messrs. E. Johnson and J. W. Sullivan and Ms. D. P. George, all of CHL. This report was prepared by Mr. Wooley.

Director of WES during preparation and publication of this report was Dr. Robert W. Whalin. COL Robin R. Cababa, EN, was Commander.

The contents of this report are not to be used for advertising, publication, or promotional purposes. Citation of trade names does not constitute an official endorsement or approval for the use of such commercial products. 


\section{Conversion Factors, Non-SI to SI Units of Measurement}

Non-SI units of measurement used in this report can be converted to SI units as follows:

\begin{tabular}{||l|l|l||}
\hline Multiply & By & To Obtain \\
\hline \hline cubic feet per second & 0.02831685 & cubic meters per second \\
\hline degree (angle) & 0.01745329 & radians \\
\hline feet & 0.3048 & meters \\
\hline miles (U.S. Statute) & 1.609344 & kilometers \\
\hline \hline
\end{tabular}




\section{Introduction}

\section{Location and Description of Prototype}

Bonneville Lock and Dam, on the Columbia River between the states of Oregon and Washington, are 145 miles ${ }^{1}$ from the Pacific Ocean and 40 miles from Portland, Oregon (Figure 1). The project consists of a 76-ft-wide by 500-ft-long lock, an adjacent powerhouse with two turbine/generator units, and an 18-bay spillway, which was placed in operation in May 1943. Eight additional turbine/generators were added to the powerhouse and placed in operation in 1943. A second powerhouse with eight turbine/generators was added to the project along the Washington shore and placed in operation in 1981. The Columbia-Snake River navigation system consists of eight locks and dams with Bonneville Dam being the most downstream and the Dalles Dam being the next one upstream. Bonneville Lock and Dam create a 48-mile-long reservoir that provides nearly a slack water pool for navigation from the Bonneville Dam upstream to the Dalles. The river at the dam is presently divided into three channels by two islands, Bradford and Cascade Islands. The tailrace for the first powerhouse forms one channel, the spillway channel the middle channel, and the tailrace channel for the second powerhouse the third channel.

The first powerhouse, with the ten turbine/generator units, has a maximum capacity of approximately 140,000 cfs with the discharge varying depending on the tailwater elevation, upper pool elevation, total riverflow, and the number of units available for use. The second powerhouse, with the eight turbine/generator units, has a maximum capacity of approximately $160,000 \mathrm{cfs}$ with the discharge varying depending on the tailwater elevation, upper pool elevation, total riverflow, and the number of units available for use. The normal operating range for the pool is between elevation (el) 71.5 and el 76.5 as measured at the dam. The tailwater elevation varies in direct relationship to the river flow from about el 7.0 at $70,000 \mathrm{cfs}$ to el 36.3 at a riverflow of $660,000 \mathrm{cfs}$.

The spillway is a concrete, gravity structure with eighteen 50-ft-wide bays separated by 10 -ft-wide piers. The original stilling basin dissipated energy with a hydraulic jump stabilized by two rows of 6-ft-high, trapezoidal-shaped baffles on a deck at el -16. In 1954 the south half of the stilling basin was repaired by replacing the downstream row of baffles by a solid end sill and streamlining the

${ }^{1}$ A table of factors for converting non-SI units of measurement to SI units is presented on page vii. 


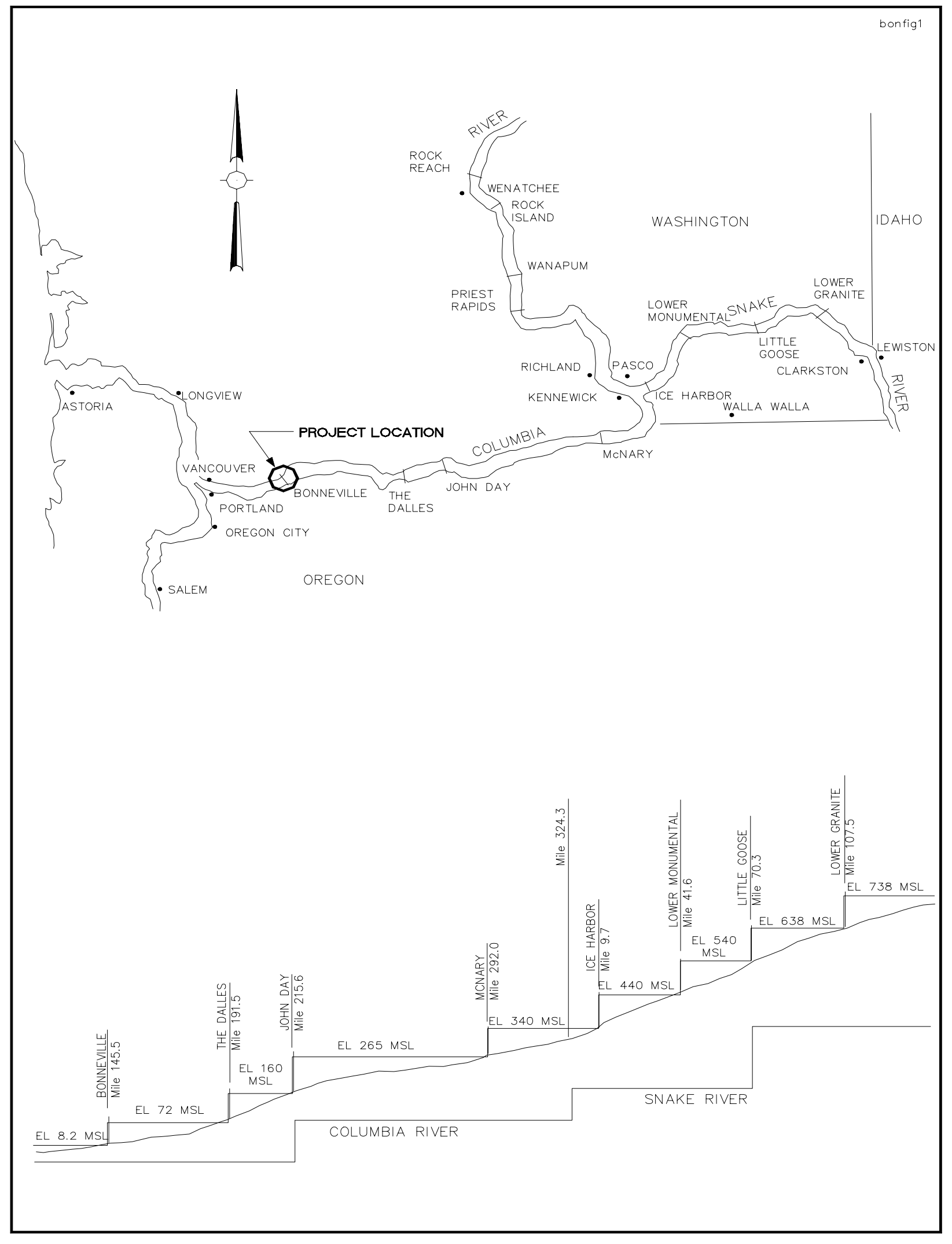

Figure 1. Project location 
upstream row. The design capacity of the spillway is $1,600,000 \mathrm{cfs}$ at pool el 82.5 and 1,170,000 cfs at pool el 75.5. The spillway releases are controlled by eighteen 50 -ft-wide by 60 -ft-high spillway gates. The crest of the spillway is at el 24.0.

Extensive fish passage facilities, both for upstream and downstream migrants, are provided at the Bonneville Project. Bonneville Dam, the first hydroelectric project that upstream-bound adult salmonids encounter on their journey to their spawning areas, is considered most important by the involved State and Federal fishery agencies. The project is also considered critical to the downstream migrants because of the large numbers of juvenile salmonids that enter the pool above Bonneville Dam from both artificial and natural propagation sources.

\section{Existing Conditions}

A decision was made in the mid-1940's to increase the size of the proposed navigation locks from the existing lock size at Bonneville ( $76 \mathrm{ft}$ wide by $500 \mathrm{ft}$ long). As a result, the seven locks in the navigation system upstream from Bonneville were constructed with useable chamber dimensions of $86 \mathrm{ft}$ (width) by $675 \mathrm{ft}$ (length) and they can pass multiple barge tows in a single lockage. Therefore, tows approach Bonneville with four or five barges and the smaller lock at Bonneville has now become the bottleneck of the system. Hazardous conditions exist both upstream and downstream of the lock due to the highvelocity currents and the alignment of the approach channel to the lock. Downbound tows approaching Bonneville stop about a mile upstream of the dam, separate the tow, and enter the channel approaching the lock pushing one or two barges. There are high-velocity currents in the navigation channel where it is constricted between Bradford Island and Eagle Point and approaching the lock and the powerhouse. Downbound tows are required to approach the lock with caution and attempt to maintain proper alignment while reducing speed to enter the lock chamber. The upstream approach to the lock has a landside guide wall which does not provide any protection for the tow from the flow moving toward the powerhouse. Because of the unfavorable currents in the upper approach, downbound tows try to hug the guide wall and enter the lock chamber without stopping. This has caused some damage to the guide wall and the wing wall of the lock. The currents in the navigation channel, the need for multiple lockage for a tow, and the distance upstream of the mooring facility have created delays of as much as $8 \mathrm{hr}$. Some navigation problems exist for upbound tows approaching the lock, although they are not as serious as the upstream approach. Upbound tows approaching the lock are required to navigate into the lower approach at a high speed to maintain control and attempt to stop in the confined approach channel.

\section{Present Development Plan}

The plan selected for refinement through additional experiments was an 86 -ft-wide by 675 -ft-long new lock constructed immediately south of the existing 
lock. The location of the new lock was influenced by the area available and the foundation for the upper gate sill. It was recognized prior to this study that major channel modification could be necessary to develop satisfactory navigation conditions for tows using the new lock. Construction of the project required excavation of the downstream lock canal through the Bonneville project grounds, and relocation of about one-quarter mile of the Union Pacific Railroad's main line and a portion of the North Pacific Division's Hydraulic Laboratory.

\section{Need for and Purpose of Model Study}

The general design of the new lock at Bonneville was based on sound theoretical design practice and experience with similar structures. However, navigation conditions vary with location and flow conditions upstream and downstream of a structure, and an analytical study to determine the hydraulic effects that can reasonably be expected to result from a particular design is both difficult and inconclusive. Since the new lock was to be located in a limited area adjacent to the existing lock and the forebay of the lock would not be parallel with the currents entering the forebay, it was important that the alignment of the channel and design of the guard wall provide satisfactory current patterns for navigation. Therefore, a comprehensive model study was considered necessary to investigate conditions that could be expected with the proposed design and to develop modifications required to ensure satisfactory navigation conditions. The specific purposes of the model study were to:

a. Investigate the proposed location for the new lock.

$b$. Determine optimum channel alignment and channel training structures required.

c. Determine modifications required to provide satisfactory navigation conditions.

$d$. Investigate the impacts of the new lock and any channel modifications on migrants and avoid or minimize any adverse effects on salmonids migrating upstream or downstream through the project.

$e$. Demonstrate to navigation interests the conditions resulting from the proposed design and to satisfy these interests of its acceptability from a navigation standpoint.

f. Design a guard wall that would provide satisfactory navigation conditions and minimize any impacts on migrants.

g. Demonstrate to navigation interests conditions that could exist during construction of the new guard wall and lock approaches. 


\section{The Model}

\section{Description}

The model (Figure 2) reproduced approximately 3.7 miles of the Columbia River channel, extending approximately 5,400 ft upstream of the dam and $14,200 \mathrm{ft}$ downstream of the dam, including the adjacent overbank area. Also included were the 76-ft-wide by 500-ft-long lock, a ten-unit powerhouse adjacent to the lock, a spillway containing eighteen bays, and an eight-unit powerhouse along the right descending bank. The model was of the fixed-bed type, with the channel and overbank areas molded in sand-cement mortar to sheet metal templates. Portions of the model, where changes in bank alignments and channel configurations could be anticipated, were molded in pea gravel to permit modifications that might be required to provide satisfactory conditions. The lock, dam crest, powerhouses, piers, and guard walls were fabricated out of sheet metal and/or Plexiglas. The dam gates were simulated schematically with simple sheet metal, slide-type gates. The model was molded to a recent hydrographic and topographic survey.

\section{Scale Relations}

The model was built to an undistorted scale of 1:100, model to prototype, to effect accurate reproduction of velocities, crosscurrents, and eddies affecting navigation. Other scale ratios resulting from the linear scale ratio are as follows:

\begin{tabular}{||l|l|l||}
\hline Characteristic & Units of Length & Model Prototype \\
\hline \hline Area & $A=$ & $1: 10,000$ \\
\hline Velocity & $V=$ & $1: 10$ \\
\hline Time & $T=$ & $1: 10$ \\
\hline Discharge & $D=$ & $1: 100,000$ \\
\hline Roughness (Manning's $\mathrm{n}$ ) & Manning's $\mathrm{n}=$ & $1: 2.15$ \\
\hline
\end{tabular}




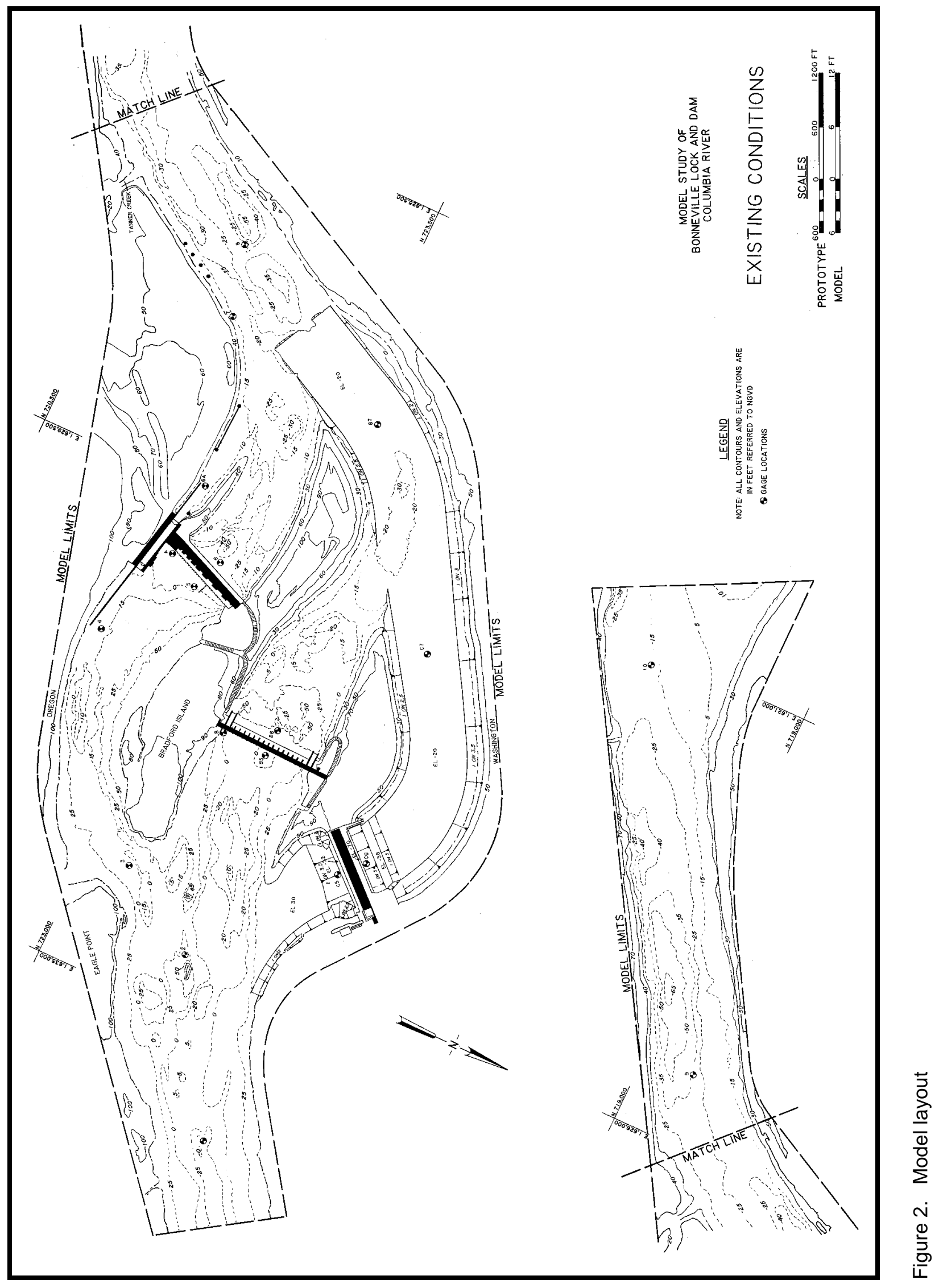


Measurements of discharges, water-surface elevations, and current velocities can be transferred quantitatively from model to prototype equivalents by means of these relations.

\section{Appurtenances}

Water was supplied to the model by means of a 10-cfs pump operating in a recirculating system. The discharge was controlled and measured at the upper end of the model by means of a valve and venturi meter. Water-surface elevations were measured by means of piezometer gauges located in the model channel and connected to a centrally located gauge pit (Figure 2). A movable tailgate was provided at the lower end of the model to control the tailwater elevation downstream of the dam, and the slide-type gates in the spillway were used to maintain the upper pool elevation during controlled riverflows.

\section{Model Adjustment}

The model was constructed with a brushed-cement mortar finish to provide a roughness factor (Manning's n) of about 0.0135 , which corresponds to a prototype of about 0.029. Based on experience with other models of this type, brushed concrete gives a close approximation of the roughness required to reproduce prototype conditions. With the model reproducing existing conditions, the model was checked against available prototype data, previous model data, and the constant discharge design tailwater and headwater rating curves. The results indicated the model reproduced with a reasonable degree of accuracy conditions in the prototype based on available data. 


\section{Experiments and Results}

Experiments were concerned primarily with the study of flow patterns, measurements of velocities and water-surface elevations, and the effects of currents on the movement of the model tow into the lock approaches during navigable riverflows. Many of the modifications were developed during preliminary experiments. Data obtained during these experiments were sufficient to assist in the development of the plan that appeared to provide satisfactory results. Results of the preliminary experiments are not included in this report.

\section{Experiment Procedures}

Experiments were conducted by introducing the proper discharges and maintaining the upper pool elevation by releasing the proper discharge through the powerhouses and the spillway. The lower pool elevation was maintained by rasing or lowering the tailgate. A selection of representative riverflows were used for the experiments based on information furnished by the U.S. Army Engineer District, Portland, as follows:

a. 70,400-cfs total riverflow (first powerhouse discharge $=28,000 \mathrm{cfs}$, spillway bays $=2,400 \mathrm{cfs}$, and second powerhouse $=40,000 \mathrm{cfs}$ ) with upper pool el 74.0 and tailwater el 7.4.

b. 118,400-cfs total riverflow (first powerhouse discharge $=56,000 \mathrm{cfs}$, spillway bays $=2,400 \mathrm{cfs}$, and second powerhouse $=60,000 \mathrm{cfs}$ ) with upper pool el 74.0 and tailwater el 11.3.

c. 200,400-cfs total riverflow (first powerhouse discharge $=98,000 \mathrm{cfs}$, spillway bays $=2,400 \mathrm{cfs}$, and second powerhouse $=100,000 \mathrm{cfs}$ ) with upper pool el 74.0 and tailwater el 16.6.

d. 335,000-cfs total riverflow (first powerhouse discharge $=140,000 \mathrm{cfs}$, spillway bays $=35,000 \mathrm{cfs}$, and second powerhouse $=160,000 \mathrm{cfs}$ ) with upper pool el 74.0 and tailwater el 16.6 (annual flow).

e. 485,000-cfs total riverflow (first powerhouse discharge $=140,000 \mathrm{cfs}$, spillway bays $=185,000 \mathrm{cfs}$, and second powerhouse $=160,000 \mathrm{cfs}$ ) with upper pool el 74.0 and tailwater el 30.7 (10-year frequency flow). 
f. 660,000 -cfs total riverflow (first powerhouse discharge $=140,000 \mathrm{cfs}$, spillway bays $=360,000 \mathrm{cfs}$, and second powerhouse $=160,000 \mathrm{cfs})$ with upper pool el 74.0 and tailwater el 36.3 (100-year frequency flow).

The upper pool elevation was controlled at Gauge B, which was located immediately upstream of the spillway in approximately the same location as the prototype gauge. The tailwater elevation was controlled to a tailwater-versusdischarge rating curve developed by the Portland District at Gauge 10, which was located near the downstream end of the model.

The river is separated into three channels through the Bonneville reach by two islands; Bradford and Cascade Islands. The channel approaching the first powerhouse and the lock forms the first channel, the main river approaching the spillway forms the middle channel, and the forebay and tailrace channel for the second powerhouse forms the third channel. The primary purpose of this study was to develop satisfactory navigation conditions with the new lock while minimizing any adverse effects of modifications on the migration of salmonids. Therefore, during the early stages of the study, the 335,000-cfs riverflow was selected as the design flow. The 335,000-cfs river flow was selected because it is an annual event, and during the event both powerhouses could be operating at maximum discharge with some flow though the spillway. This would tend to create the maximum velocities in the navigation channel approaching the existing and new locks and high velocities near the confluence of the lock canal and the river channel downstream of the dam.

Velocities and current directions were measured in the model by means of wooden cylindrical floats weighted on one end to simulate the maximum permissible draft for loaded barges using the waterway (14-ft prototype). The paths of floats were plotted with respect to ranges established for that purpose, and velocities were measured by timing the travel of the floats over measured distances. In turbulent areas or where eddies or crosscurrents exist, only the main trends are shown. Point velocities were measured with a miniature magnetic velocity meter that measured both the velocity and direction of the current. Confetti was used to illustrate the surface current pattern and time-lapse photography was used to record the pattern for comparison to other plans. Dye was also introduced into the model to illustrate the current pattern and these patterns were recorded with time-lapse photography. Surges in water-surface elevation were measured with sonic water-level gauges and surges in the velocity of the current were measured with a miniature velocity meter.

With existing conditions, downbound tows using the Bonneville Lock must break or reduce the size of their tow to one or two barges before entering the channel between Bradford Island and the Oregon shore. Therefore, a model tow representing a towboat and two barges was used to demonstrate, document, and evaluate navigation conditions with the model simulating existing conditions. With the new lock in place, a model tow, consisting of a towboat and four barges, was used to demonstrate, document, and evaluate the effects of currents on tows approaching and leaving the new lock and while moving through the river channel upstream and downstream of the lock. The overall size of the 
towboat and tow selected for design of the project was $650 \mathrm{ft}$ long by $84 \mathrm{ft}$ wide loaded to a draft of $14 \mathrm{ft}$. The towing industry indicated there are several barge configurations that would fit these dimensions. However, only one of the configurations would have a significant influence on the maneuvering capabilities of the tow and could influence the overall evaluation of navigation conditions. The towboat could be centered behind the flotilla of barges allowing the tow full maneuvering capabilities or the towboat could be set to one side of the flotilla with a small barge alongside of the towboat. The latter conditions would restrict the maneuvering characteristics of the towboat and increase the difficulty for a tow to maneuver through the reach. It was decided early on that the more maneuverable arrangement would be used in the preliminary design of the project and the final design would be evaluated with the more restricted tow. The tow was equipped with twin screws and propelled by a small electric motor operating from batteries located in the tow; the rudders and speed of the tow were remote controlled. The towboat could be operated in forward or reverse with the power adjusted by means of a rheostat to a maximum speed comparable to that of the towboats expected to use the Columbia River waterway.

\section{Base Experiments with Existing Conditions}

\section{Description}

Base experiments were conducted with the model reproducing existing conditions as shown in Figure 2. The purposes of the experiments were to verify that the model was reproducing known prototype conditions and to provide information and data that could be used to evaluate the effects of the proposed modifications on water-surface elevations, current direction and velocities, and navigation conditions. The principal features reproduced or simulated in the model, as shown in Figures 2 - 9, included:

a. A navigation lock with clear chamber dimensions of $76 \mathrm{ft}$ wide by $500 \mathrm{ft}$ long along the Oregon shore (Figure 5). The top of the lock walls were at el 85.0. A landside 668.6-ft-long guide wall extended upstream of the lock and a 516-ft-long guide wall extended downstream from the lock.

b. A 1,024-ft-long powerhouse with ten generator/turbines extended across the channel from the lock along the Oregon shore to Bradford Island (Figures 3 - 5).

c. A 1,230-ft-long spillway with 18 gate bays extended across the main river channel from Bradford Island to the Washington shore (Figure 6). The crest of the dam is at el 24.0.

d. A second powerhouse with eight generator/turbine units extended from Cascade Island to the Washington shore (Figure 7).

e. Various fish ladder and bypass units. 


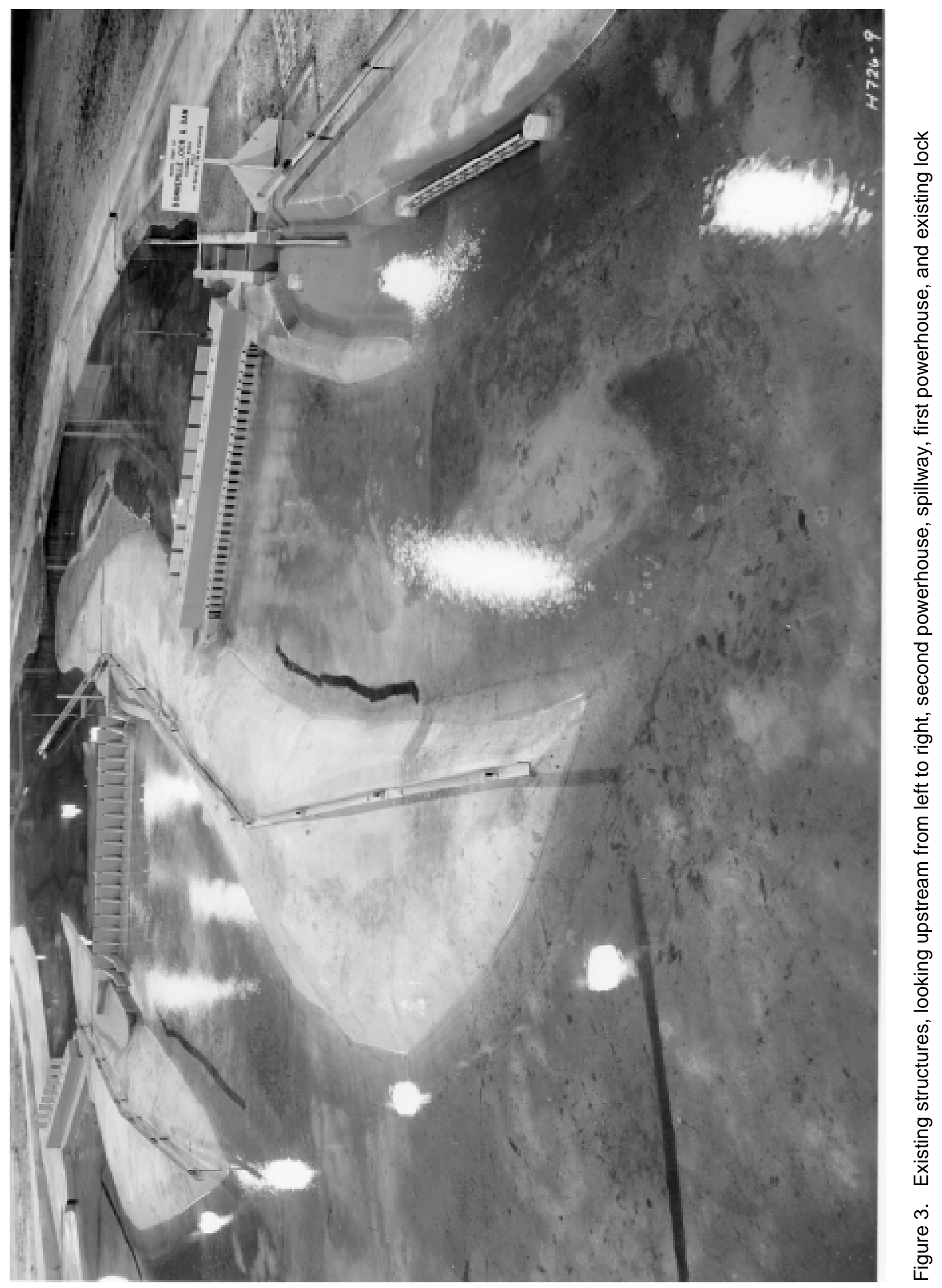

Chapter 3 Experiments and Results 


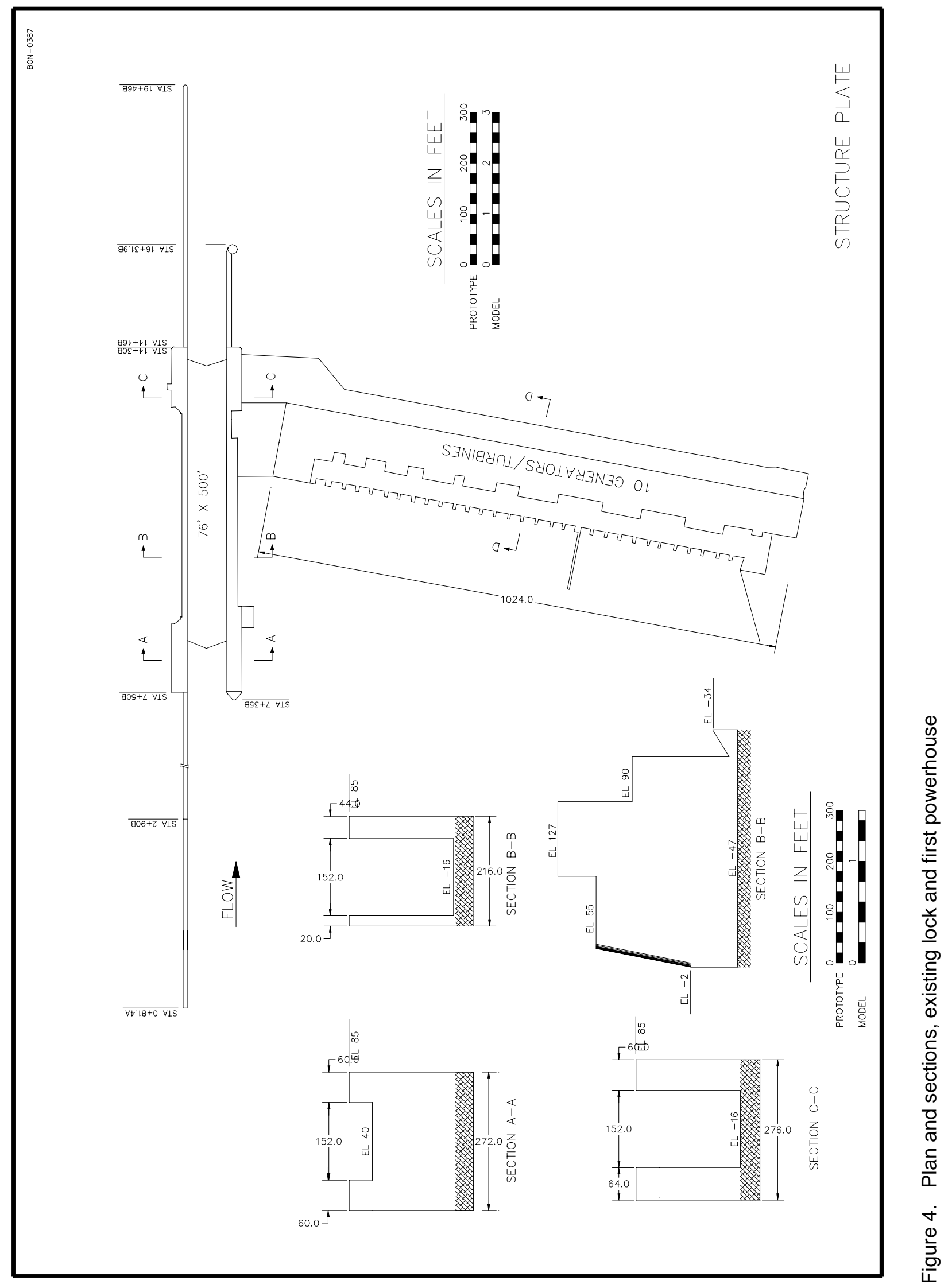




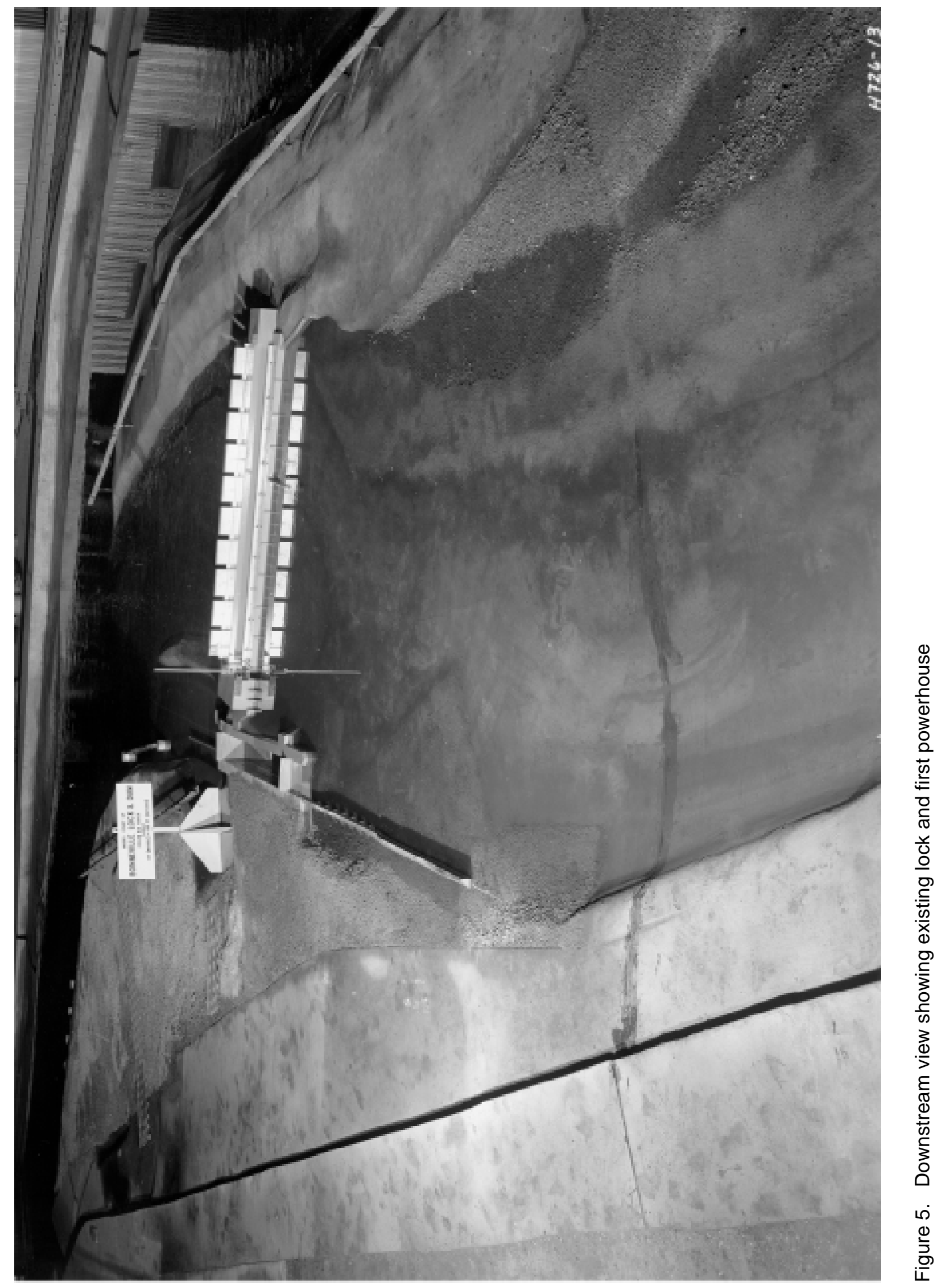




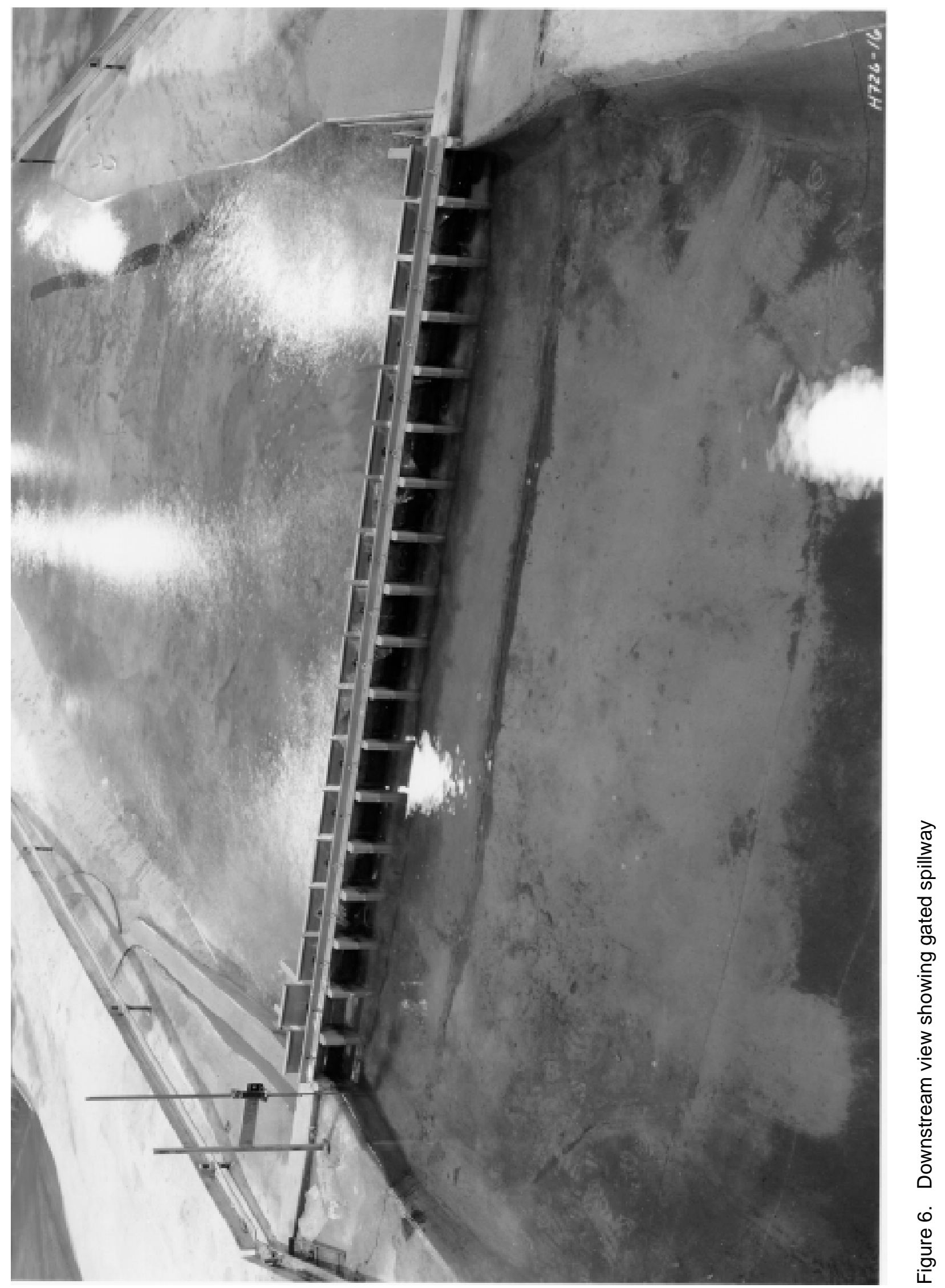




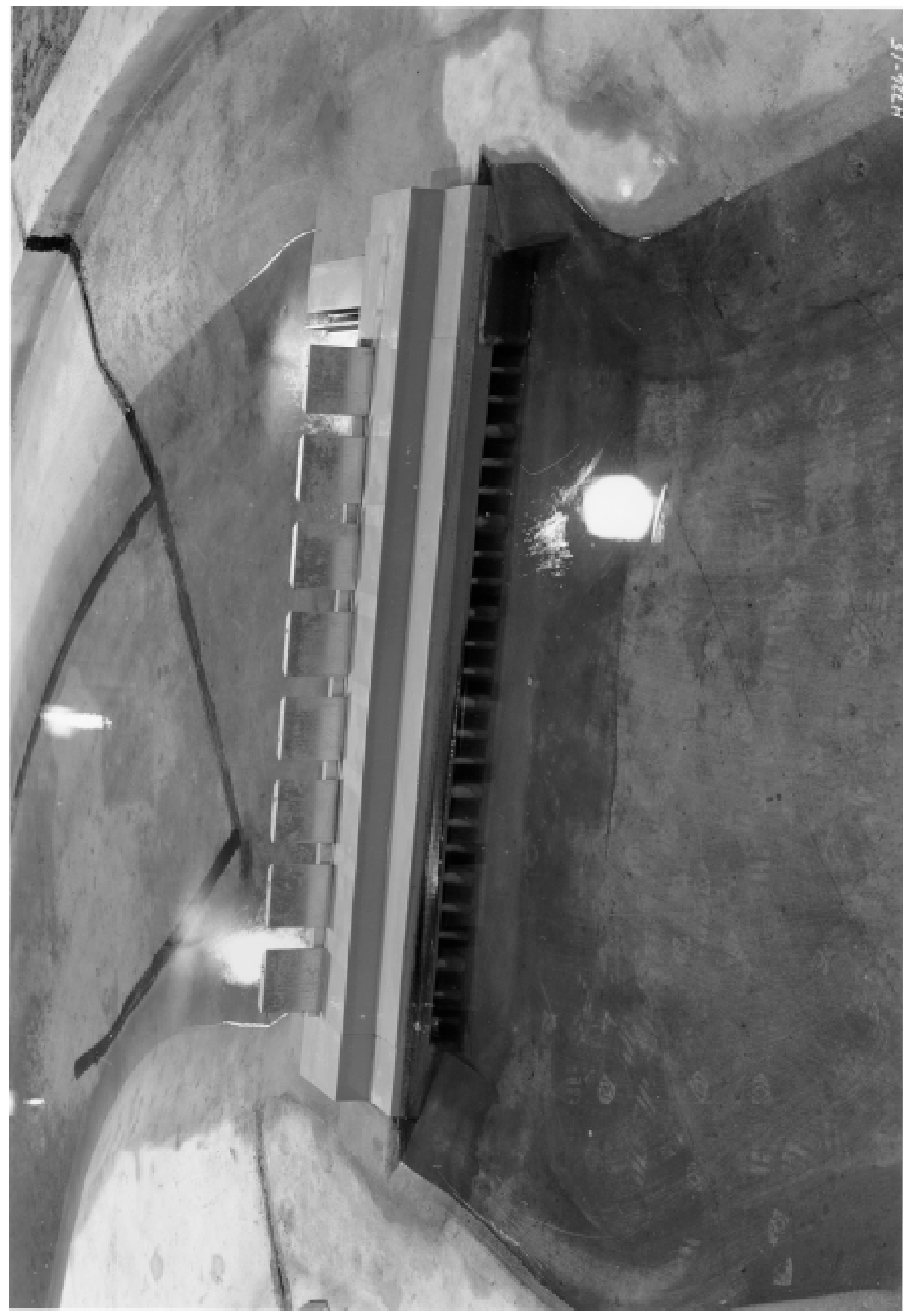

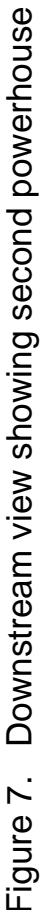




\section{Results of base experiments with existing conditions}

Water-surface elevations. Water-surface elevations obtained with existing conditions are shown in Table 1. These data that show the slope in watersurface elevation along the navigation channel varied from less than 0.1 to $0.1 \mathrm{ft}$ per mile upstream of the dam (Gauges 1-5) with the 70,400- and 485,000-cfs riverflows, respectively, and from about 0.2 to $1.0 \mathrm{ft}$ per mile downstream of the dam (Gauges 6-10) with the 70,400- and 660,000-cfs riverflows, respectively.

Current directions and velocities. Current directions and velocities obtained with existing conditions are shown in Plates 1 - 6. These data show that the currents separate from the left bank as it enters the modeled reach and a large counterclockwise eddy forms along the left bank immediately upstream of Eagle Point. The currents move past Eagle Point and reattach to the left bank about 1,200 ft downstream of Eagle Point and then run parallel to the left bank to the lock. At that point, the current turns toward the powerhouse. With the lower river discharges when the powerhouse discharge was low, a large clockwise eddy formed along the Oregon shore of Bradford Island that extended upstream from the powerhouse to the head of Bradford Island. As the riverflow increased and the powerhouse discharge increased, the eddy reduced in size. The maximum velocity of the currents that influenced tows in the upstream approach to the lock varied from 1.0 to $5.2 \mathrm{fps}$ upstream of Eagle Point, 1.0 to $3.8 \mathrm{fps}$ in the channel between Eagle Point and the head of Bradford Island, and 0.5 to $4.5 \mathrm{fps}$ near the upstream end of the guide wall with the 70,400- and 335,000-cfs (annual event) riverflows, respectively. As the riverflow increased to 660,000 cfs (100-year event) the velocity of the currents in the main channel near Eagle Point and in the channel between Eagle Point and Bradford Island increased, but the velocity of the currents approaching the lock remained about the same because the powerhouse discharge remained the same. Downstream of the lock the flow passing through the powerhouse follows the left bank of the powerhouse tailrace, moves across the lower approach of the lock, and then runs parallel to the left bank from the lock downstream to Tanner Creek. A large low-velocity eddy formed in the mouth of the lock approach. The maximum velocity of the currents that would affect tows entering and leaving the lock ranged from 2.0 to 5.0 fps near the lower lock approach, 3.6 to 10.9 fps near Tanner Creek, and 3.0 to $6.6 \mathrm{fps}$ about $5,000 \mathrm{ft}$ downstream of Tanner Creek with the 70,400 and $335,000 \mathrm{cfs}$ (annual event) riverflows, respectively. As the riverflow increased to $660,000 \mathrm{cfs}$ (100-year event), the velocity of the currents increased somewhat.

Current directions and velocities measured with the magnetic velocity meter are shown in Plates 7 - 12. Measurements were made near the water surface, at mid-depth in the water column, and near the bottom of the channel. These measurements were made along the navigation channel where modifications were expected to be made so a comparison could be made later between base conditions and the recommended plan for the project. As expected, these data show some differences in the direction and velocity of the currents compared to the float velocities and differences between measurements made at different depths through the water column. 
Navigation conditions. Due to the navigation conditions, channel configuration, and lock size, tows were pushing one or two barge tows through the project. Therefore, model experiments were conducted with a 42 -ft-wide by 500 -ft-long tow representing two 42 -ft-wide by $200-\mathrm{ft}$-long barges with a $100-\mathrm{ft}-$ long pusher. These experiments were to verify that the model was reproducing known navigation conditions prior to installation of the new lock and its appurtenances. Downbound tows could drive through the channel between Eagle Point and Bradford Island by favoring the Bradford Island side, drive to the lock guide wall, start reducing speed along the guide wall, and enter the lock chamber. However, if the tow stopped upstream of the lock chamber or reduced speed to a normal approach speed (1.0 - $2.0 \mathrm{mph})$, the head of the tow was moved toward the powerhouse and had great difficulty holding on the guide wall. Upbound tows encountered high-velocity currents in the channel between Bradford Island and the Oregon shore but could move upstream without any major difficulties provided they had sufficient power to push against the currents. An upbound tow had some difficulties making the turn from the Bradford Island channel into the main river channel due to the alignment of the channel and the alignment and velocity of the currents in the reach.

\section{Experiments with Original Design}

\section{Description}

The original design (Figures 8 and 9) was the same as existing conditions, except for the following:

a. A navigation lock with clear chamber dimensions of $86 \mathrm{ft}$ wide by $675 \mathrm{ft}$ long with a 900-ft-long floating guard wall was added immediately inland of the existing lock ( Figure 9). The tops of the lock walls were at el 90.

$b$. The new 900-ft-long floating guard wall extended upstream from the riverside lock wall to sta $12+90.43$. The bottom of the guard wall was $15 \mathrm{ft}$ below the water surface or about $1 \mathrm{ft}$ below the normal draft of a loaded barge $(14 \mathrm{ft})$.

c. The existing upper guide wall of the lock was removed and the left bank was excavated to provide a navigation channel approaching the new lock.

$d$. A solid guide wall extended upstream from the landside lock wall about $1,360 \mathrm{ft}$ to sta $8+23.62$. The guide wall was angled about $15 \mathrm{deg}$ landward from the center line of the new lock and extended upstream to tie into the existing bank. The guide wall also served as a retaining wall for the left bank excavation. A 50-ft-wide berm with a top elevation of 45.0 extended along most of the length of the wall to provide stability. The top of the guide wall was at el 81.0. 


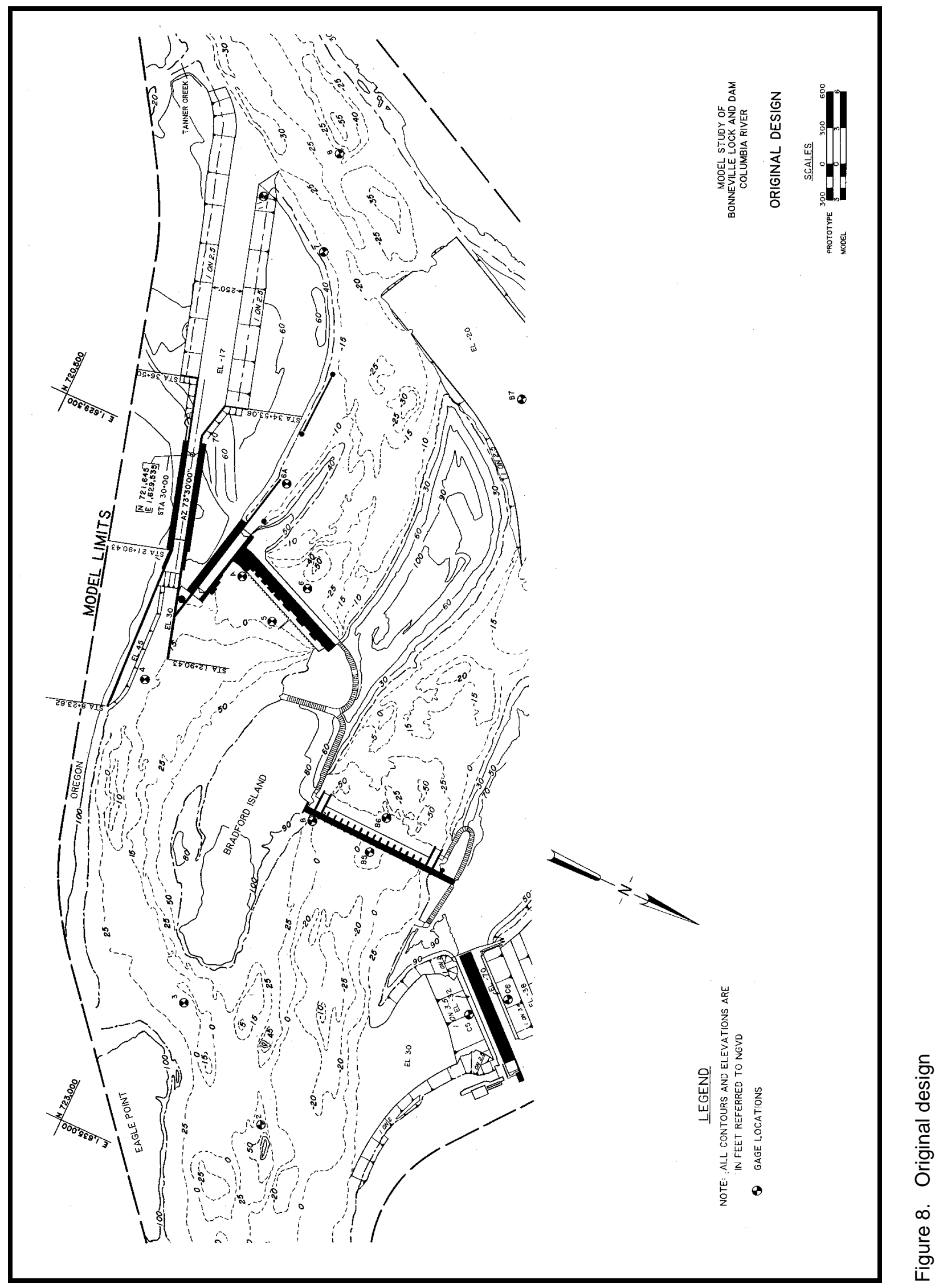




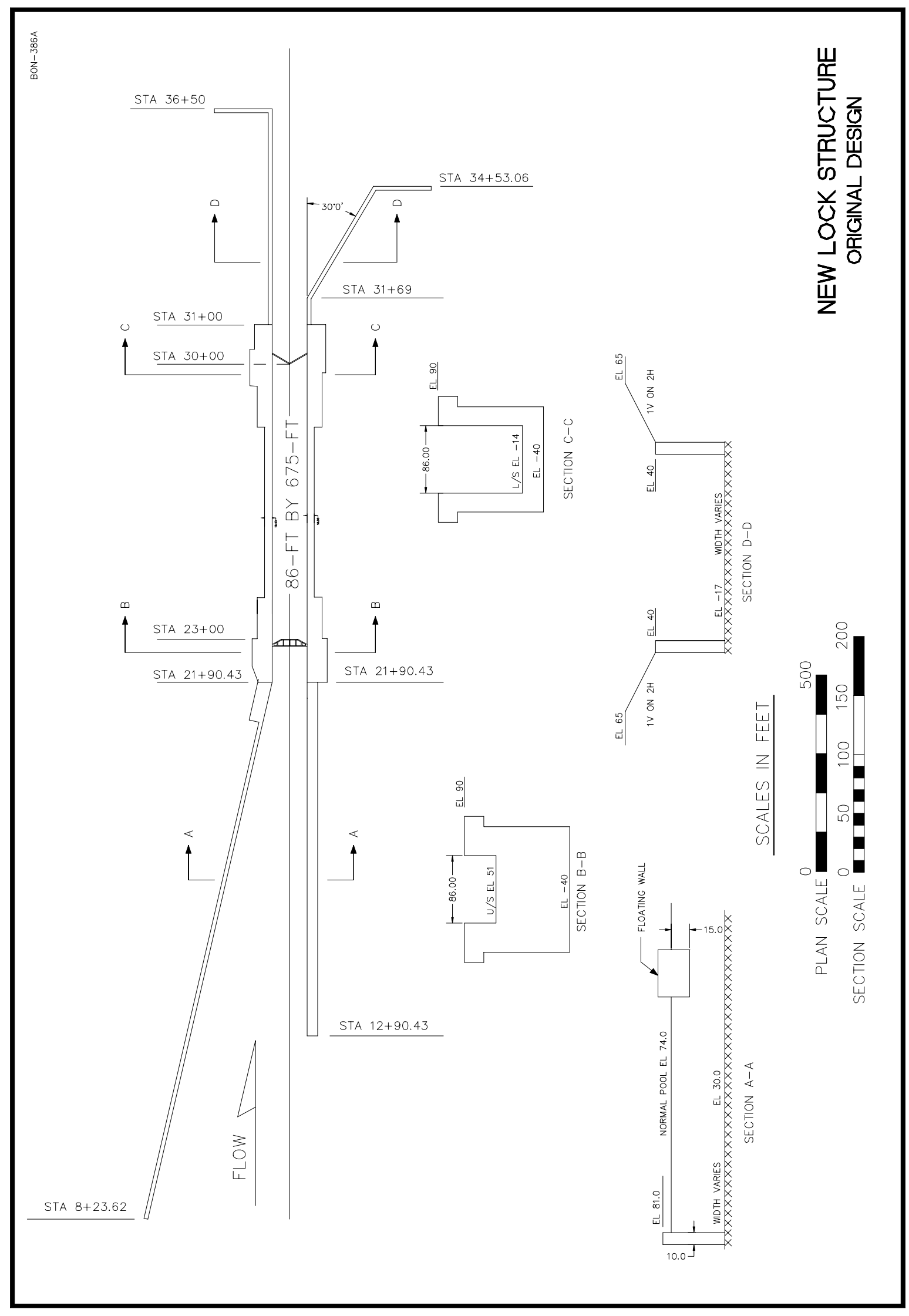

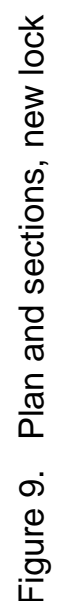

Chapter 3 Experiments and Results 
e. About $400 \mathrm{ft}$ of the upstream end of the existing lock guide wall was removed to allow construction of a guard wall for the new lock.

f. A 50-ft-diam cell was placed in the angle between the old guide wall and the new guard wall to support the floating guard wall.

g. A 550-ft-long guide/retaining wall extended downstream from the landside lock wall and was in line with the lock chamber. A 284.06-ftlong guide/retaining wall extended downstream from the riverside lock wall and was angled toward the river 30 deg relative to the center line of the lock.

$h$. A 250-ft-wide channel extended downstream from the new lock to its confluence with the main river channel. The bottom of the channel was at el -17.0 with side slopes of $1 \mathrm{~V}$ on $2.5 \mathrm{H}$. The channel entered the main river channel at an angle of about $40 \mathrm{deg}$.

\section{Results of experiments with original design}

Water-surface elevations. Water-surface elevations obtained with the original design are shown in Table 2. These data show that the slope in watersurface elevations was generally the same as with existing conditions except for minor changes near the new lock approach and the downstream end of the lock canal.

Current directions and velocities. Current directions and velocities obtained with the original design are shown in Plates 13 - 17. Confetti showing current patterns in the upper lock approach with the 335,000-cfs total riverflow and the first powerhouse discharge of 140,000 cfs is shown in Photo 1. These data show that the currents in the main river channel and the first powerhouse channel were generally the same as with existing conditions, except in the immediate vicinity of the new lock. The currents in the first powerhouse channel generally followed the left bank approaching the new lock and moved across the upper lock approach toward the first powerhouse. The guard wall of the new lock extended upstream into the navigation channel at an angle to the currents. The currents approached the upper end of the new guard wall at an angle of about $25 \mathrm{deg}$ and the velocity of the currents varied from about 1.0 to $3.4 \mathrm{fps}$ with flows ranging from 70,000 to $660,000 \mathrm{cfs}$. These data show a large lowvelocity counterclockwise eddy formed in the downstream entrance of the lock canal. The velocity of the currents moving across the entrance of the canal varied from about 1.3 to $6.2 \mathrm{fps}$. Upbound tows approaching the lock would navigate along the right bank to a point opposite the canal entrance, move across the river, and turn into the canal. The velocity of the current they would encounter varied from about 3.3 to $16.8 \mathrm{fps}$ along the right bank opposite Tanner Creek, 3.4 to $12.3 \mathrm{fps}$ at mid-river opposite the canal entrance, and 1.3 to $6.2 \mathrm{fps}$ at the canal entrance with the 70,400- and 660,000-cfs riverflows, respectively. 
Navigation conditions. With the new lock in place, navigation experiments were conducted using the 650 -ft-long by 84 -ft-wide design size tow loaded to a draft of $14 \mathrm{ft}$. The more maneuverable configuration ( towboat centered behind the barges) was used for the initial evaluation and design. These experiments indicate navigation conditions could be hazardous for tows entering and leaving the upper lock approach with riverflows of 200,400 cfs and above. Downbound tows had major difficulties navigating through the channel between the upstream end of Bradford Island and Eagle Point due to the alignment and the velocity of the currents. The large eddy that formed along the left bank immediately upstream of Eagle Point increased the maneuvering required for the tow to exit the main river channel and enter the first powerhouse channel. A downbound tow, moving close along the left bank upstream of Eagle Point, was moved into the eddy and out of alignment with the channel entrance. The tow was then required to make additional maneuvers to navigate around Eagle Point with a possibility of being grounded on the point. With the higher riverflows when the spillway was in operation, tows approaching the entrance to the first powerhouse channel 200 to $300 \mathrm{ft}$ riverward of the left bank had difficulties making the turn into the first powerhouse channel and then turning to align with the lock due to the sharp "S" turn in the navigation channel and the alignment and velocity of the currents. The alignment and velocity of the currents along the left bank in the first powerhouse channel made navigating the channel very difficult. As the tow reduced speed to enter the forebay of the lock, there was a strong tendency for the currents to move the tow riverward of the guard wall and into the powerhouse (Photos 2 and 3). As the tow entered the lock forebay the head of the tow was pulled toward the guard wall with considerable force and the tow approached the guard wall at about a 20-deg angle and had difficulties landing on the wall at a safe speed. There was a tendency for the tow to be pinned on the guard wall by the currents, and upbound tows had major difficulties breaking free of the wall and moving upstream out of the lock forebay. A tow moving upstream out of the lock forebay aligned with the guard wall would be rotated around the upstream end of the guard wall and may not be able to recover before being moved into the powerhouse (Photo 4). Therefore, the tow was required to execute maneuvers to move the head of the tow away from the guard wall and align with the landside guide wall prior to moving out of the forebay. These maneuvers could require considerable time and be very difficult to execute. An upbound tow would also have difficulties making the turn from the powerhouse channel into the main river channel due to the alignment and velocity of the currents.

With the higher riverflows, downbound tows leaving the lower lock approach would have some difficulties moving from the lock canal into the main river channel. As the tow left the lock canal and entered the river channel, there was a tendency for the currents to move the tow into the left bank of the canal at its intersection with the river channel. A normal approach to the new lock for upbound tows would be to navigate along the right bank in the slower velocities to a point opposite the canal entrance, then cribbing or moving across the river, remaining parallel with the currents and the bank, and turn into the canal by allowing the head of the tow to rotate into the canal entrance while maintaining control of the tow. Tows with sufficient power to move upstream against the 
currents could approach the entrance to the canal without any major difficulties. However, when the tow started its turn into the lock canal there was not sufficient clearance for the tow to make the required maneuver. There was a tendency for either the head of the tow to be grounded on the right descending bank of the canal or the stern of the tow to be grounded on the left bank of the canal.

Lock Emptying Experiments. Experiments were conducted to measure surges in water-surface elevations and the velocity of the currents in the downstream lock canal at selected locations (Figure 10). Surges were recorded during lock emptying with various head. Surges in water-surface elevations were measured with head ranging from 66.2 to $36.8 \mathrm{ft}$ with the 70,400 and 660,000 cfs riverflows, respectively (Plates 18 - 23) and surges in velocities were recorded with head differentials ranging from 66.2 to $56.6 \mathrm{ft}$ with the 70,400 and 200,400 cfs riverflows, respectively (Plates 24 - 26). These data show that a maximum change in water-surface elevation of approximately $1.5 \mathrm{ft}$ occurred with the maximum head of $70.2 \mathrm{ft}$. An initial surge of positive $0.8 \mathrm{ft}$ occurred approximately $4 \mathrm{~min}$ after the start of lock emptying and a return surge of about $-0.7 \mathrm{ft}$ occurred approximately $10 \mathrm{~min}$ after start of emptying when the emptying cycle was completed. The largest surge occurred near the lock at sta 3 and decreased in magnitude as the stations approached the river channel. As the riverflow increased, the magnitude of the surges in water-surface elevations decreased due to a decrease in head and increased depth in the lock canal. Emptying the lock created maximum velocities at sta 3 and $4 \mathrm{~A}$ that varied from +3.8 fps to $-0.8 \mathrm{fps}$ with the 70,400 -cfs riverflow and a head of $70.2 \mathrm{ft}$. The maximum positive velocity occurred about $8 \mathrm{~min}$ after start of lock filling and the negative velocity occurred about 5 min later. A change in velocities was still occurring about 25 min after start of lock emptying. As the riverflow increased, the magnitude of the surges in the velocity decreased due to a decrease in head and increase in water depth in the canal.

\section{Experiments with Plans A through A-3}

\section{Description}

These experiments were conducted to develop a system of submerged dikes to improve the alignment of the currents approaching the new lock and to reduce the outdraft near the upstream end of the new guard wall. Plan A was the same as the original design except a system of six submerged dikes was added upstream of the new lock. The dikes were placed in the deep part of the navigation channel along the left descending bank. The dikes were spaced about $300 \mathrm{ft}$ apart with the first dike being placed at sta $8+23.62$. Positions, alignments, and elevations of the dikes are shown in Figure 11.

Plan A-1 was the same as Plan A, except: submerged Dike 1-A was added in the navigation channel approaching the new lock about $300 \mathrm{ft}$ downstream of Dike 1 with top el 45.0, and the top elevation of submerged Dikes 1, 2, and 3 


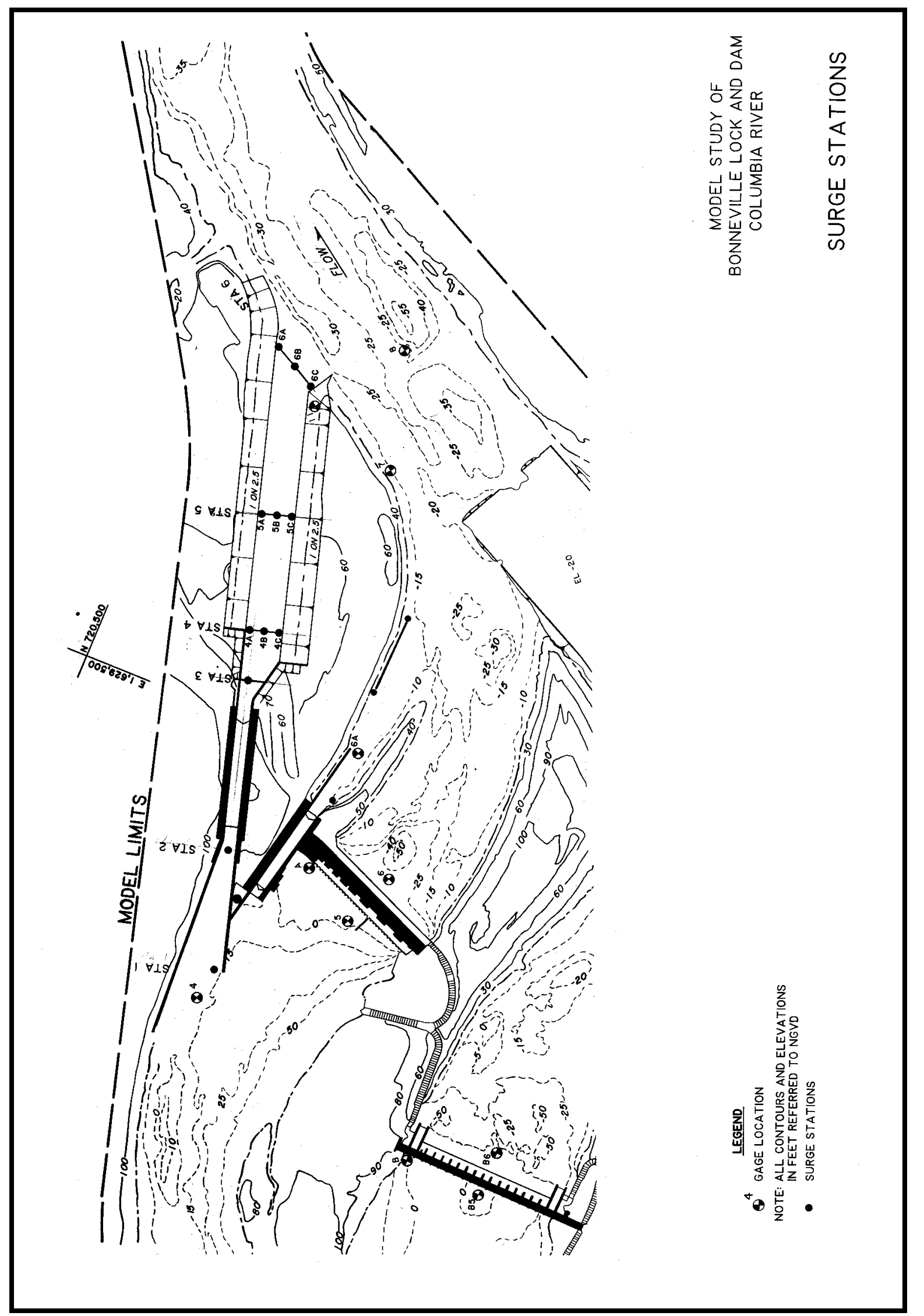

0
0
.0
$\frac{0}{0}$
0
0
0
0
5
0
0

$\frac{0}{0}$
$\stackrel{0}{5}$
은 


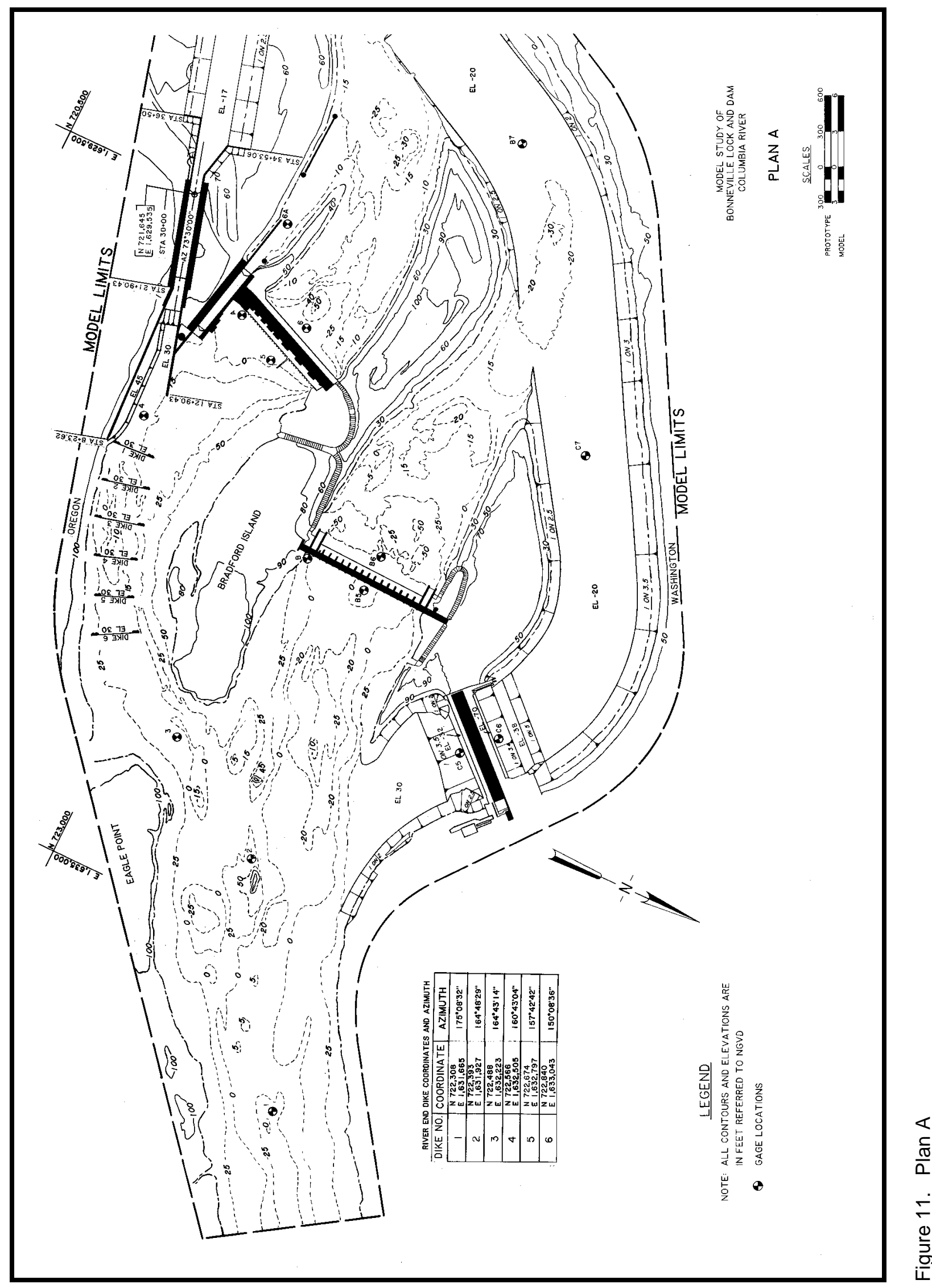


was raised from el 30 to el 45.0, 40.0, and 35.0, respectively. Positions and alignments of the dikes are shown in Figure 12.

Plan A-2 (Figure 13) was the same as Plan A-1 except four submerged dikes spaced $300 \mathrm{ft}$ apart with top el of 40.0 were placed in the channel upstream of Eagle Point along the left bank. Positions and alignments of the dikes are shown in Figure 13.

Plan A-3 (Figure 14) was the same as Plan A-1 except three spur dikes were added along the left descending bank immediately upstream of Eagle Point. The dikes were constructed with side slopes of $1 \mathrm{~V}$ on $2.5 \mathrm{H}$ and a top el of 76.0. Positions and alignments of the dikes are shown in Figure 14.

\section{Results of experiments with Plans A through A-3}

Water-surface elevations. Water-surface elevations obtained with Plans A through A-3 are shown in Table 3. These data show the slope in water-surface elevations increases through the first powerhouse channel compared to the original design. At Gauge 5, in the immediate forebay of the first powerhouse, the decrease in water-surface elevations varied from about $0.4 \mathrm{ft}$ with Plan A to about $0.9 \mathrm{ft}$ with Plan A-3. This can be attributed to reducing the channel area by adding the submerged dikes. Slopes of the water-surface elevations downstream of the dam were generally the same as with the original design.

Current directions and velocities. Current directions and velocities obtained with Plan A are shown in Plate 27. These data show the submerged dikes improved the alignment of the current approaching the new lock. However, the velocity of the currents increases about $1.0 \mathrm{fps}$ compared to the original design. The dikes increased the flow along Bradford Island and the size and intensity of the eddy upstream of the powerhouse decreased considerably. The velocity and alignment of the currents upstream of Eagle Point were generally the same as with the original design.

Current directions and velocities obtained with Plan A-1 are shown in Plate 28. These data show that adding Dike 1-A and raising Dikes 1, 2, and 3 did not significantly influence the currents approaching the new lock compared to Plan A. However, the currents were better aligned with the guide wall.

Current directions and velocities obtained with Plan A-2 are shown in Plate 29. These data show that adding the four submerged dikes along the left bank upstream of Eagle Point improved the alignment of the currents approaching Eagle Point without significantly increasing the velocity of the currents. Downstream of Eagle Point, the currents were generally the same as with Plans A and A-1.

Current directions and velocities obtained with Plan A-3 are shown in Plate 30. These data show that adding four spur dikes along the left bank immediately upstream of Eagle Point eliminated the eddy along the left bank and 


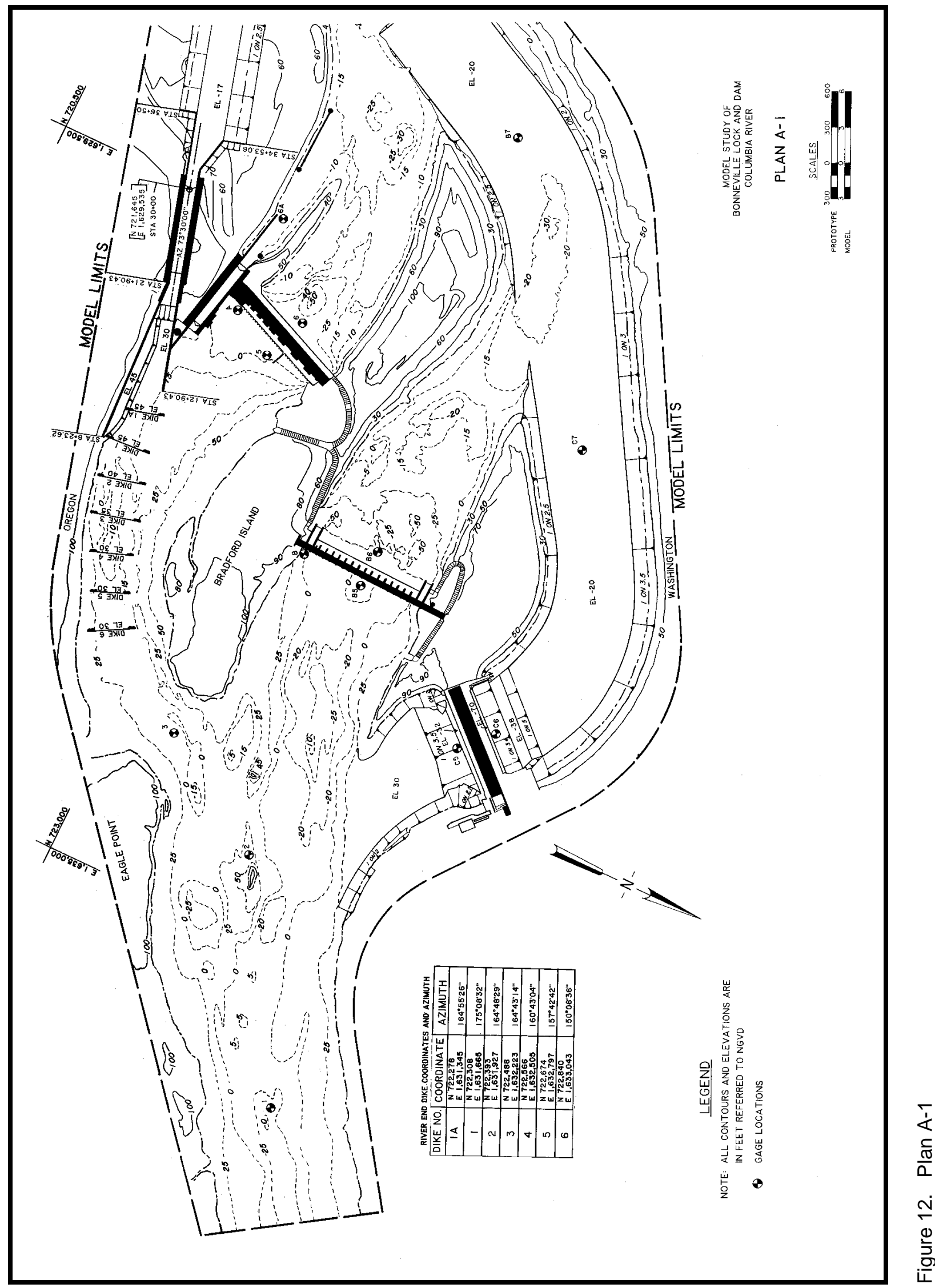




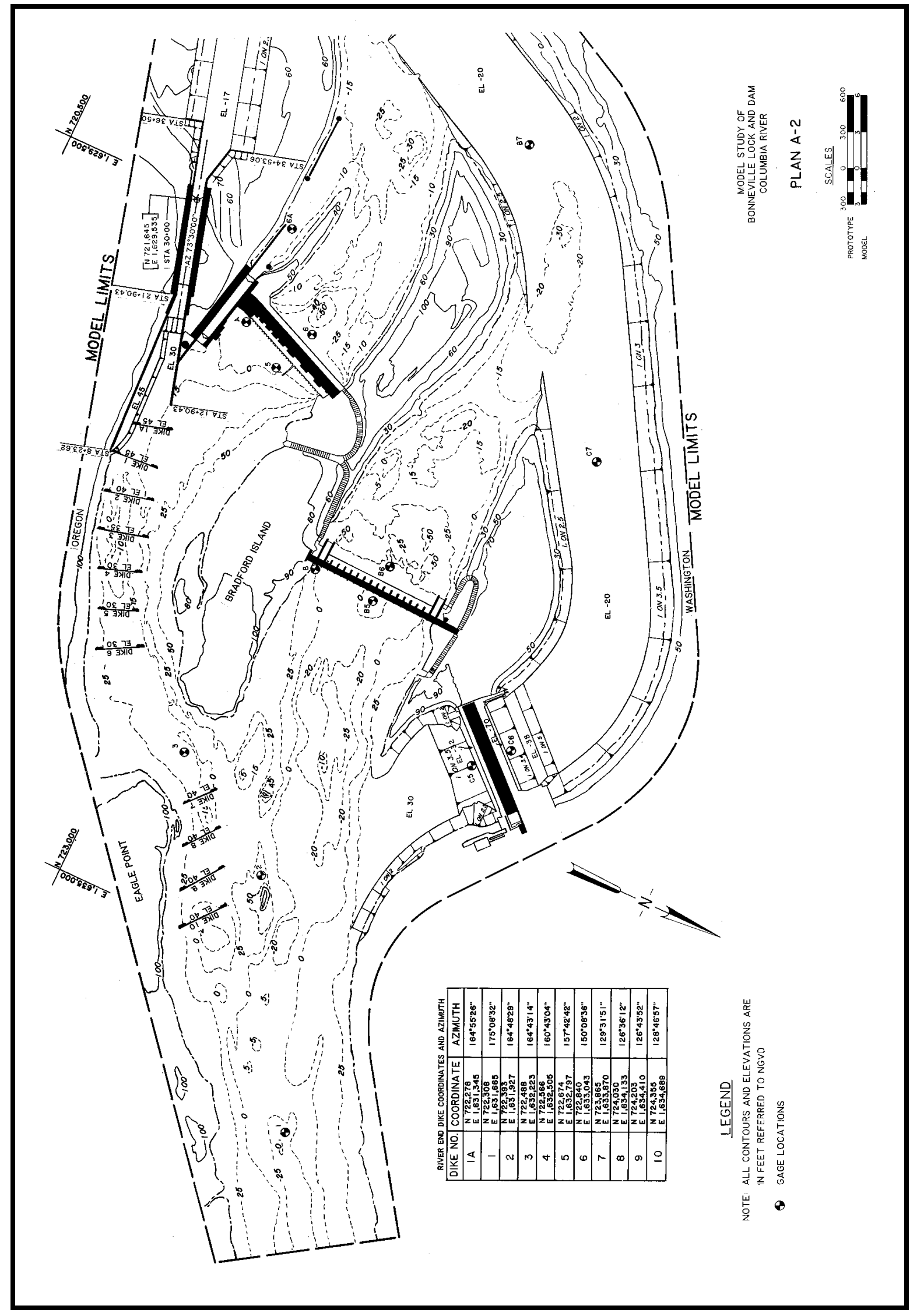

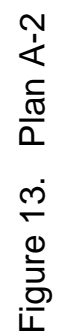




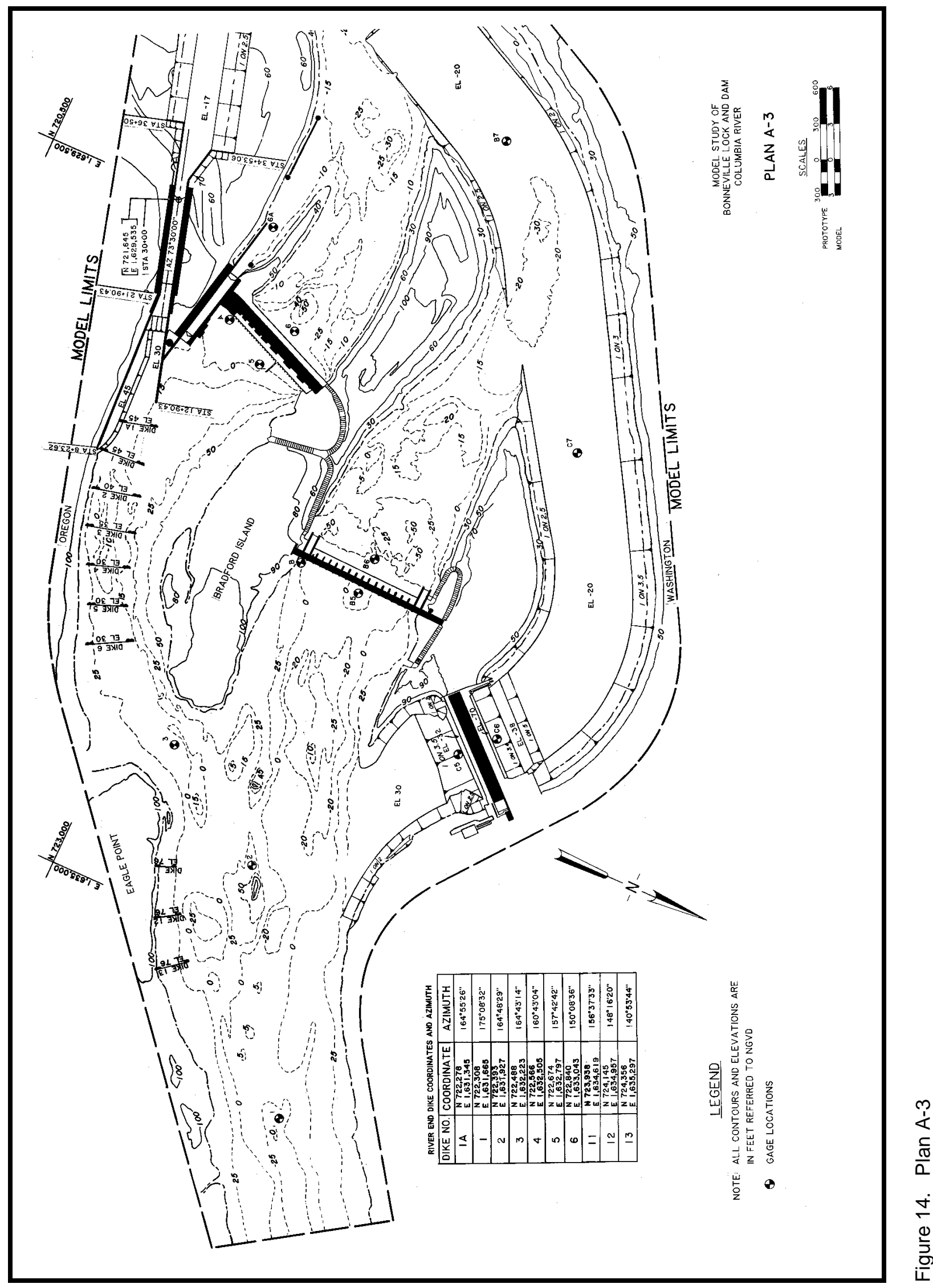


improved the alignment of the currents approaching Eagle Point without increasing the velocity of the currents. The currents were generally the same downstream of Eagle Point as with Plans A, A-1, and A-2.

Navigation conditions. With Plan A, navigation conditions were improved slightly for tows entering and leaving the new lock. However, navigation conditions in the vicinity of Eagle Point were the same as with the original design. Navigation conditions with Plan A-1 were generally the same as with Plan A. With Plan A-2, the submerged dikes installed upstream of Eagle Point improved navigation conditions for downbound tows approaching Eagle Point but the tow would have difficulties making the " $\mathrm{S}$ " turn into the first powerhouse channel and aligning with the new lock. Navigation experiments indicated that an upbound tow would have some difficulties turning out of the first powerhouse channel and moving upstream over the submerged dikes. An upbound tow moving over the dikes near their river end would have difficulties maintaining control and making the turn. With Plan A-3, the spur dikes improved navigation conditions for tows navigating past Eagle Point. Downbound tows could move close along the river ends of the dikes, approach Eagle Point with good alignment and make the turn into the first powerhouse channel with a minimum of maneuvering. However, the tow had difficulties recovering from the turn and aligning with the new lock. There was a tendency for the tow to either strike the left bank or overcompensate and miss the lock approach. Navigation conditions for tows leaving the first powerhouse channel were improved somewhat. If the tow held the head of the tow in close to Eagle Point, it could turn into the main river channel and move upstream along the river ends of the spur dikes without major difficulties. However, if the tow navigated along the center of the channel, it would have some difficulties making the turn into the main river channel.

\section{Experiments with Plans B through B-2}

Series B experiments were an effort to improve the alignment of the currents and navigation conditions for tows turning into the channel between Eagle Point and Bradford Island. Several combinations of dikes and Eagle Point excavations were evaluated with the 335,000-cfs riverflow.

\section{Description}

Plan B (Figure 15) was the same as Plan A-1, except Eagle Point was excavated landward about $100 \mathrm{ft}$ at el 40.0 with a $1 \mathrm{~V}$ on $1 \mathrm{H}$ bank slope. The coordinates of the excavation are shown on Figure 15.

Plan B-1 (Figure 16) was the same as Plan B except four submerged spur dikes with top el 40.0 were placed along the left bank immediately upstream of Eagle Point (same as Plan A-2 submerged dikes). The dikes were angled downstream and spaced about $300 \mathrm{ft}$ apart. Positions and alignments of the dikes are shown in Figure 16. 


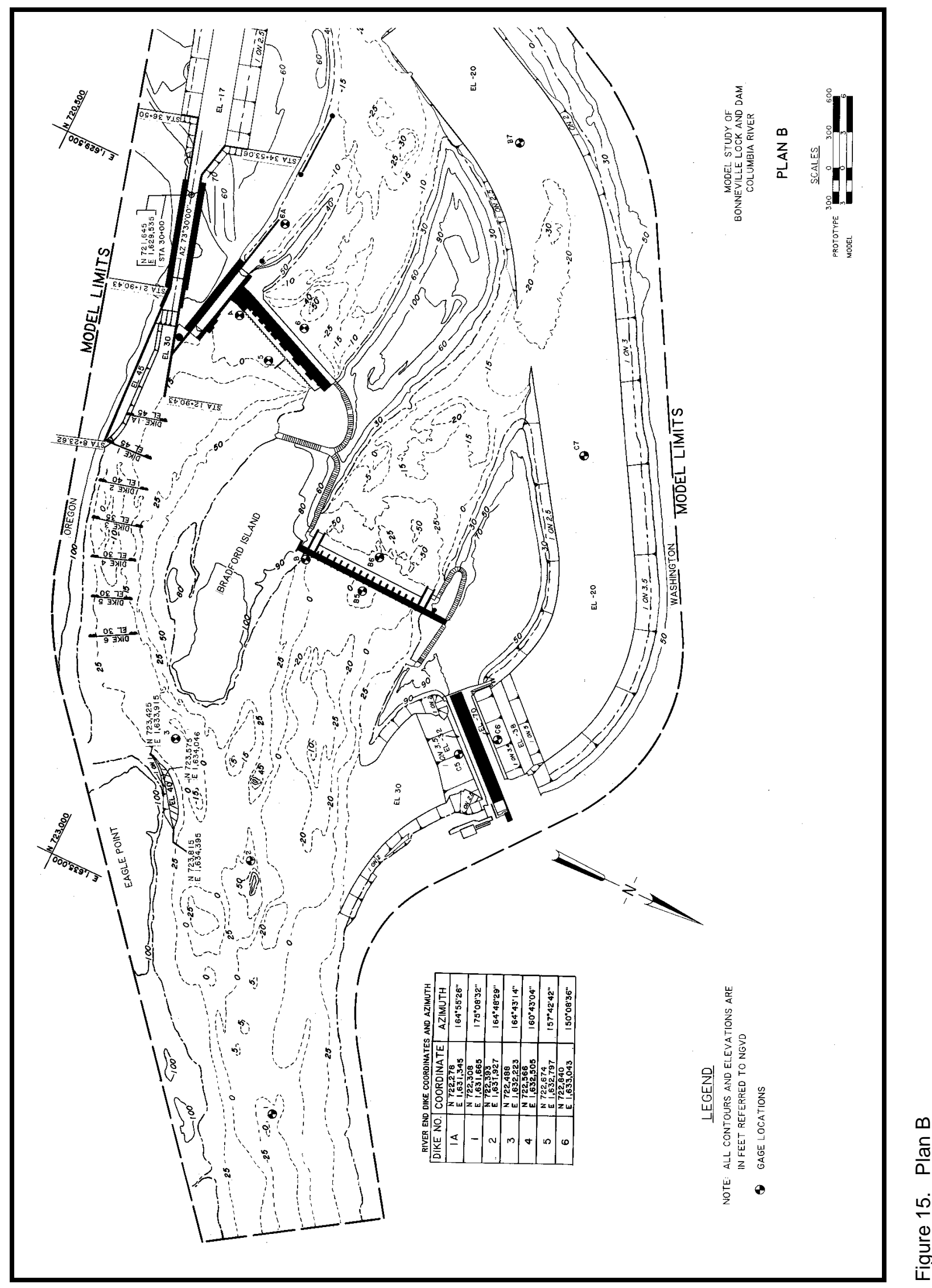




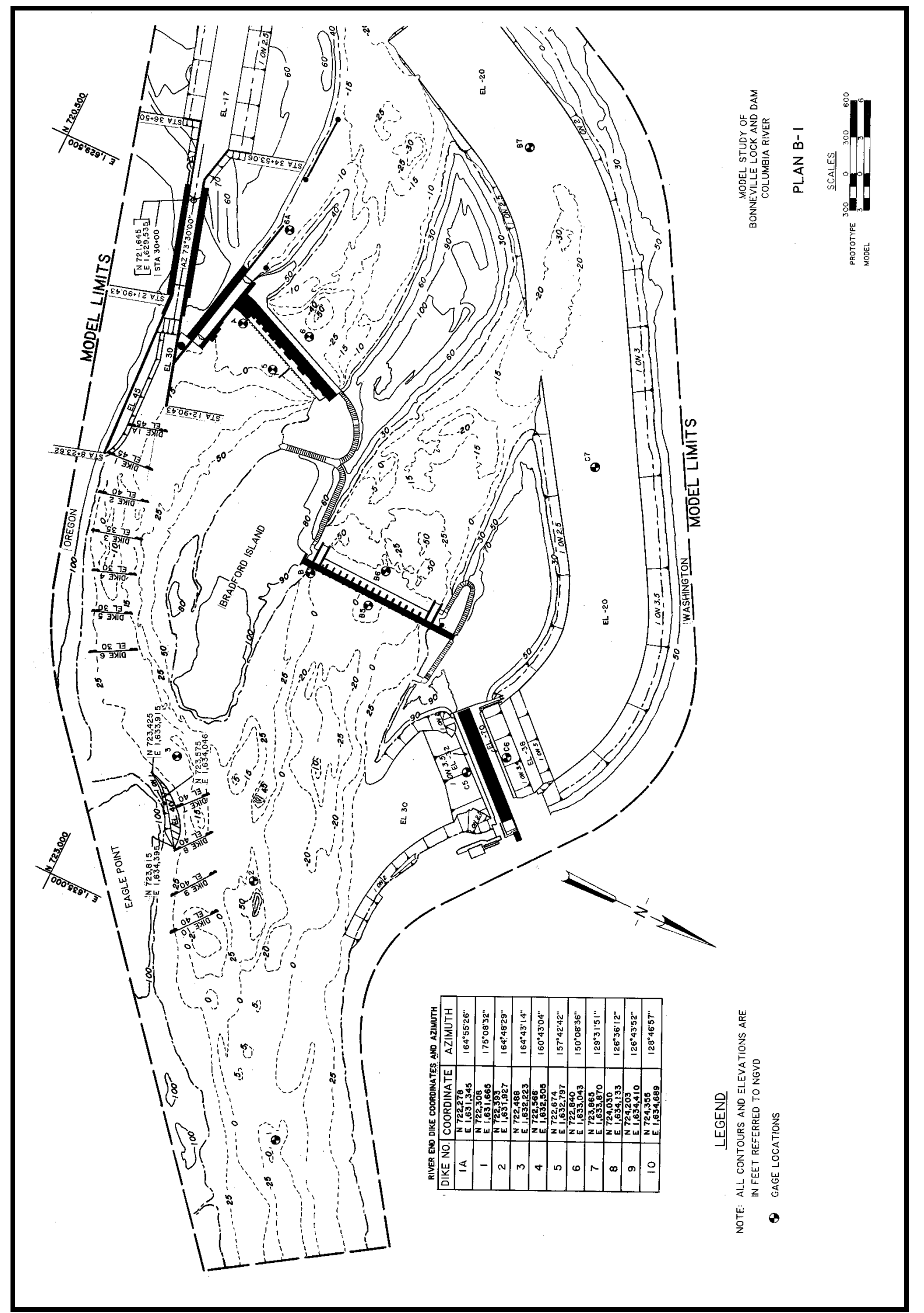

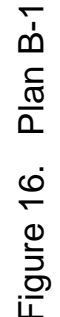


Plan B-2 (Figure 17) was the same as Plan B except three spur dikes with top el 78.0 were added upstream of Eagle Point (same as Plan A-3 spur dikes). The dikes were normal to the flow and spaced about $300 \mathrm{ft}$ apart. Positions and alignments of the dikes are shown in Figure 17.

\section{Results of experiments with Plans B through B-2}

Water-surface elevations. Water-surface elevations obtained with Plans B through B-2 are shown in Table 4. These data show that the slope in watersurface elevation through the first powerhouse channel was generally the same as with the Plan A series experiments.

Current directions and velocities. Current directions and velocities obtained with Plans B through B-2 are shown in Plates 31 - 33. These data show that with Plan B (Plate 31) there was a slight difference in the alignment and velocity of the current in the vicinity of Eagle Point. However, the currents in the first powerhouse channel from Eagle Point to the new lock were generally the same as with Plan A or when compared to the original design, the velocities of the currents were about 1.0 fps greater in the vicinity of the approach of the new lock.

Current directions and velocities obtained with Plan B-1 are shown in Plate 32. These data show that adding the submerged dikes upstream of Eagle Point created unstable currents in the area with the floats moving both landward and riverward of the dikes. Velocities of the currents were generally the same as with Plan B.

Current directions and velocities obtained with Plan B-2 are shown in Plate 33. These data show that adding the spur dikes upstream of Eagle Point improved the alignment of the currents through the reach without increasing the velocity of the currents.

Navigation conditions. Navigation conditions with Plan B for tows entering and leaving the immediate forebay of the new lock were generally the same as with Plan A series experiments. However, excavation of Eagle Point improved navigation conditions slightly by allowing a downbound tow to approach Eagle Point 200 to $300 \mathrm{ft}$ riverward and then steer the head of the tow closer to the point, thereby reducing the maneuvering required for the tow to turn into the first powerhouse channel. There was still a tendency for a downbound tow moving close along the left bank to be pulled landward of Eagle Point by the eddy that forms along the left bank upstream of Eagle Point. The tow was then required to drive riverward around Eagle Point increasing the degree of turn into the first powerhouse channel.

With Plan B-1, upbound and downbound tows had difficulties maintaining course over the submerged dikes. There was a tendency for the tow to be moved either toward the bank or riverward of the dike ends. 


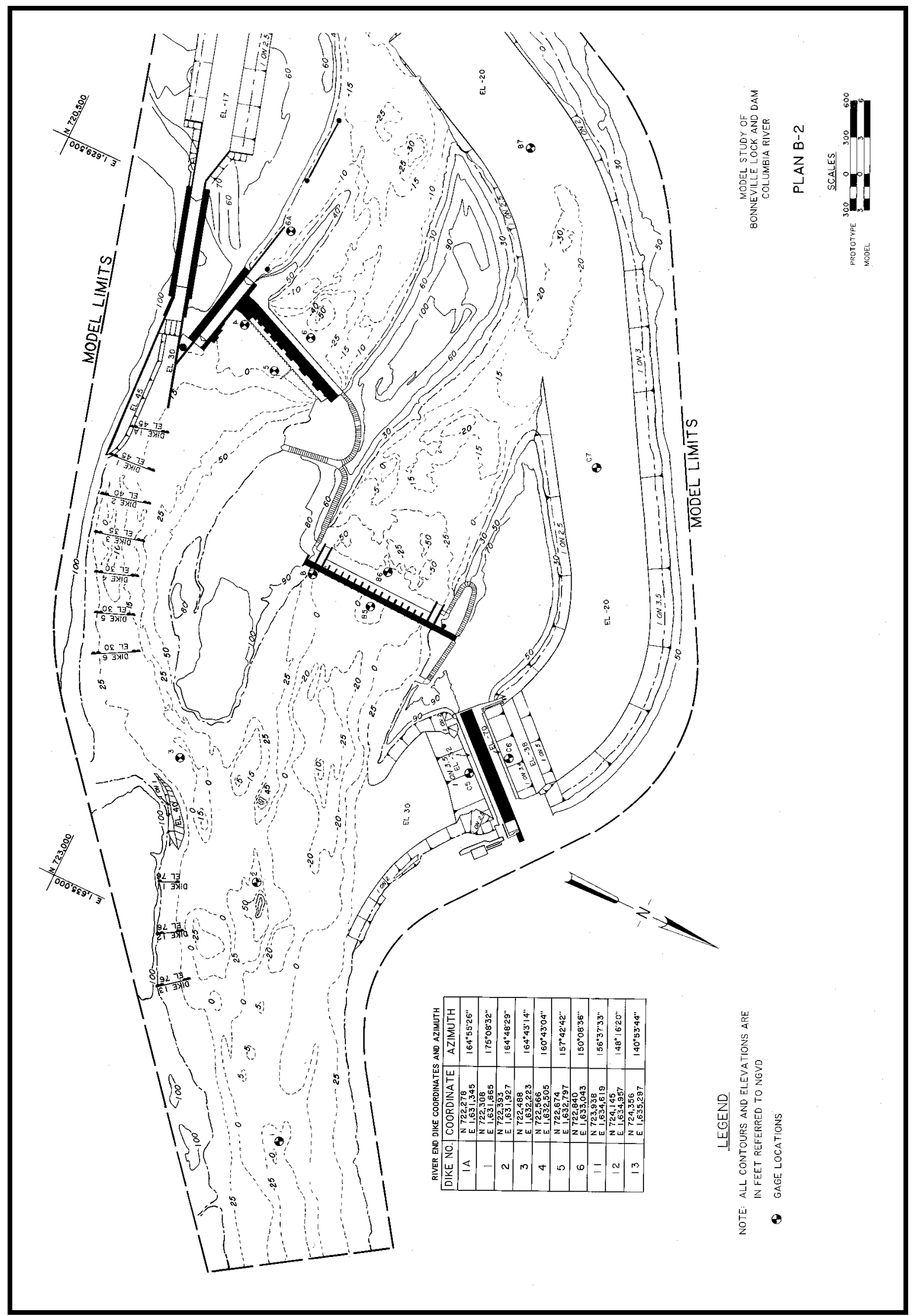

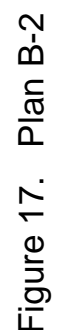


Plan B-2 improved navigation conditions for tows moving past Eagle Point. Downbound tows could drive along the river end of the spur dike, drive the head of the tow close to the Eagle Point excavation, and make the turn into the first powerhouse channel with a minimum of maneuvering. The tow did have some difficulty completing the " $\mathrm{S}$ " turn and aligning with the new lock. There was a tendency for the tow to either strike the left bank or overcompensate and navigate over the ends of the submerged dikes, which in turn would move the tow out of alignment with the new lock. Upbound tows could navigate the reach from the upstream end of the first powerhouse channel past the Eagle Point excavation and the spur dikes without any major difficulties.

\section{Experiments with Plans C through C-9}

The Plan C series were preliminary experiments to improve the alignment of the currents and navigation conditions for tows turning into the channel between Eagle Point and Bradford Island and entering and leaving the new lock. Several combinations of dikes, Eagle Point excavations, and Bradford Island excavations were evaluated with the 335,000-cfs riverflow.

\section{Description}

The Plan C experiments are shown in Figures 18 - 27. The principal features shared by all plans are as follows: a new lock with its guide and guard walls the same as the original design and a system of seven submerged dikes in the deep part of the navigation channel approaching the new lock (same as Plan A-1). The submerged dikes were spaced about $300 \mathrm{ft}$ apart, with Dike 1 placed at sta 8+23.62. Dikes 2 - 5 were placed upstream of Dike 1 and Dike 1-A was placed downstream of Dike 1 . The crests of the dikes were at elevations 45, 45, 40, 35, 30, 30, and 30 for Dikes 1-A, 1, 2, 3, 4, 5, and 6, respectively. Locations, alignments, and elevations of the submerged dikes are shown in the coordinate table in Figure 18. Characteristics of the Plan C experiments are as follows:

Plan C (Figure 18) was the same as A-3, except the left descending bank of Bradford Island was excavated landward about $350 \mathrm{ft}$ at el 30.0. The coordinates of the excavation are shown in Figure 18.

Plan C-1 (Figure 19) was the same as Plan C, except Eagle Point was excavated landward about $100 \mathrm{ft}$ at el 40.0 (same as B-2). The coordinates of the Eagle Point excavation are shown in Figure 19.

Plan C-2 (Figure 20) was the same as Plan C-1, except the Eagle Point excavation was increased to about $150 \mathrm{ft}$ at el 40.0 and the alignment of the excavation was changed slightly. The coordinates of the revised Eagle Point excavation are shown in Figure 20.

Plan C-3 (Figure 21) was the same as Plan C, except the Bradford Island left bank excavation was increased by excavating landward about $350 \mathrm{ft}$ at 


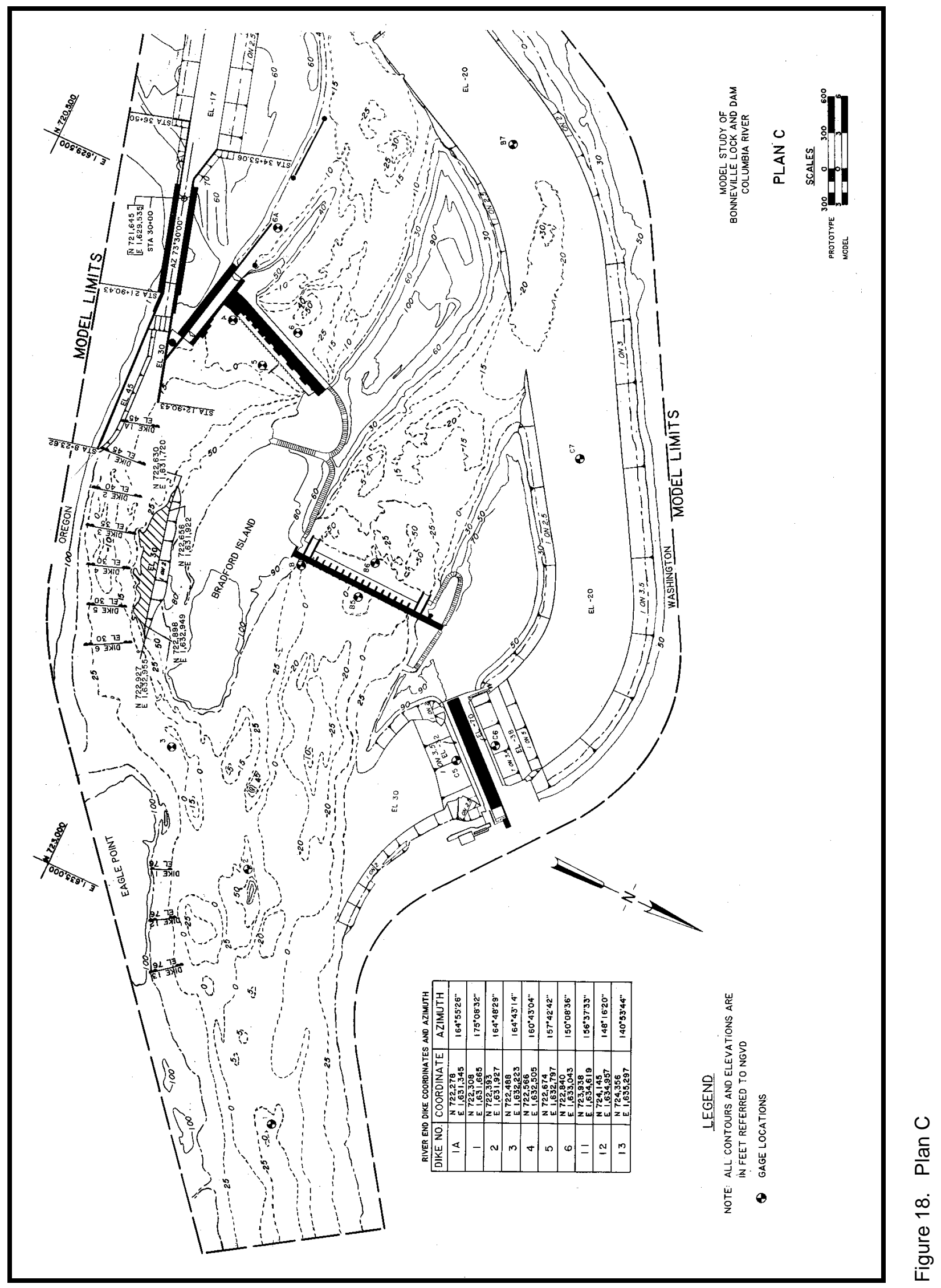

Chapter 3 Experiments and Results 


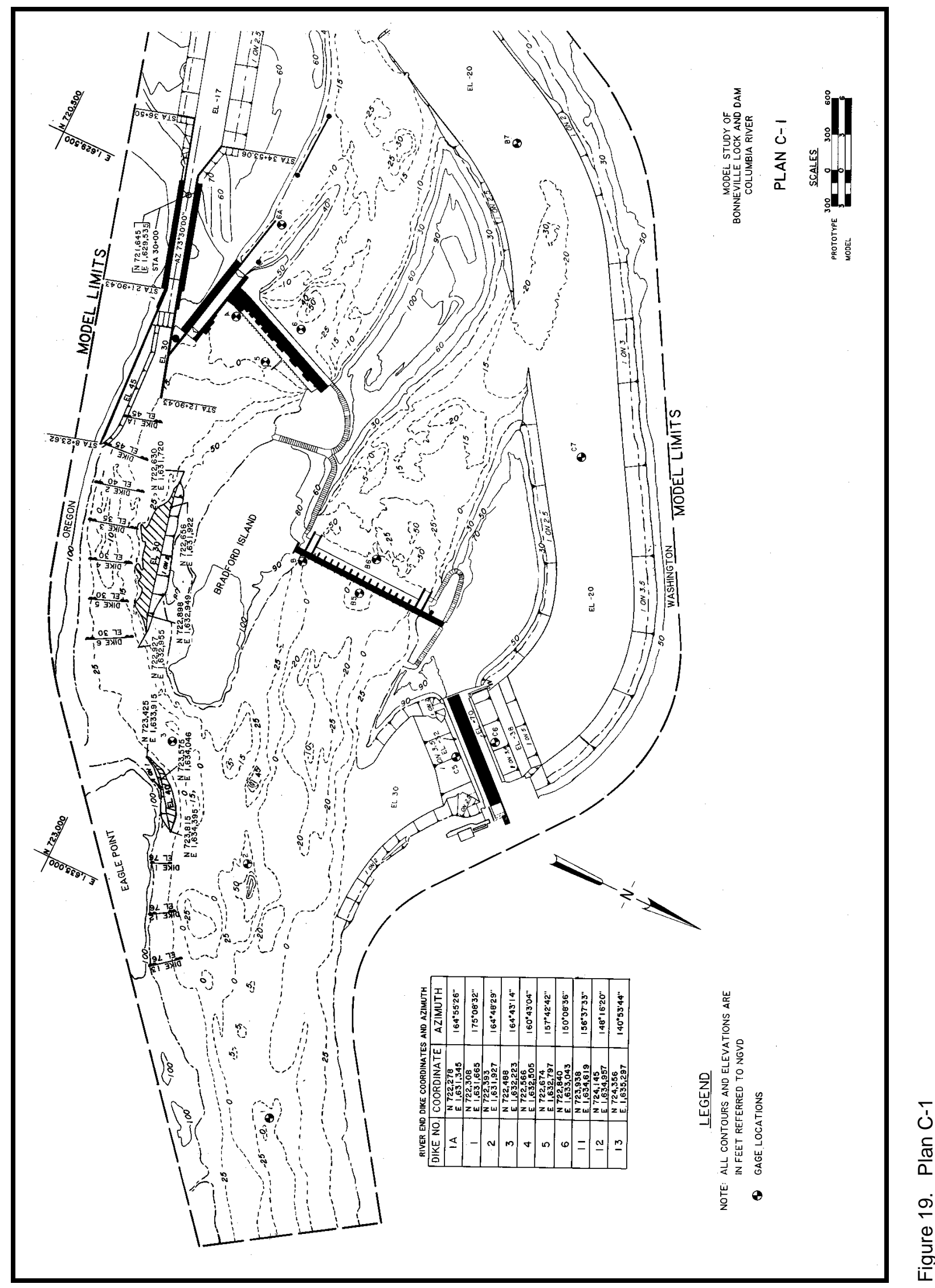




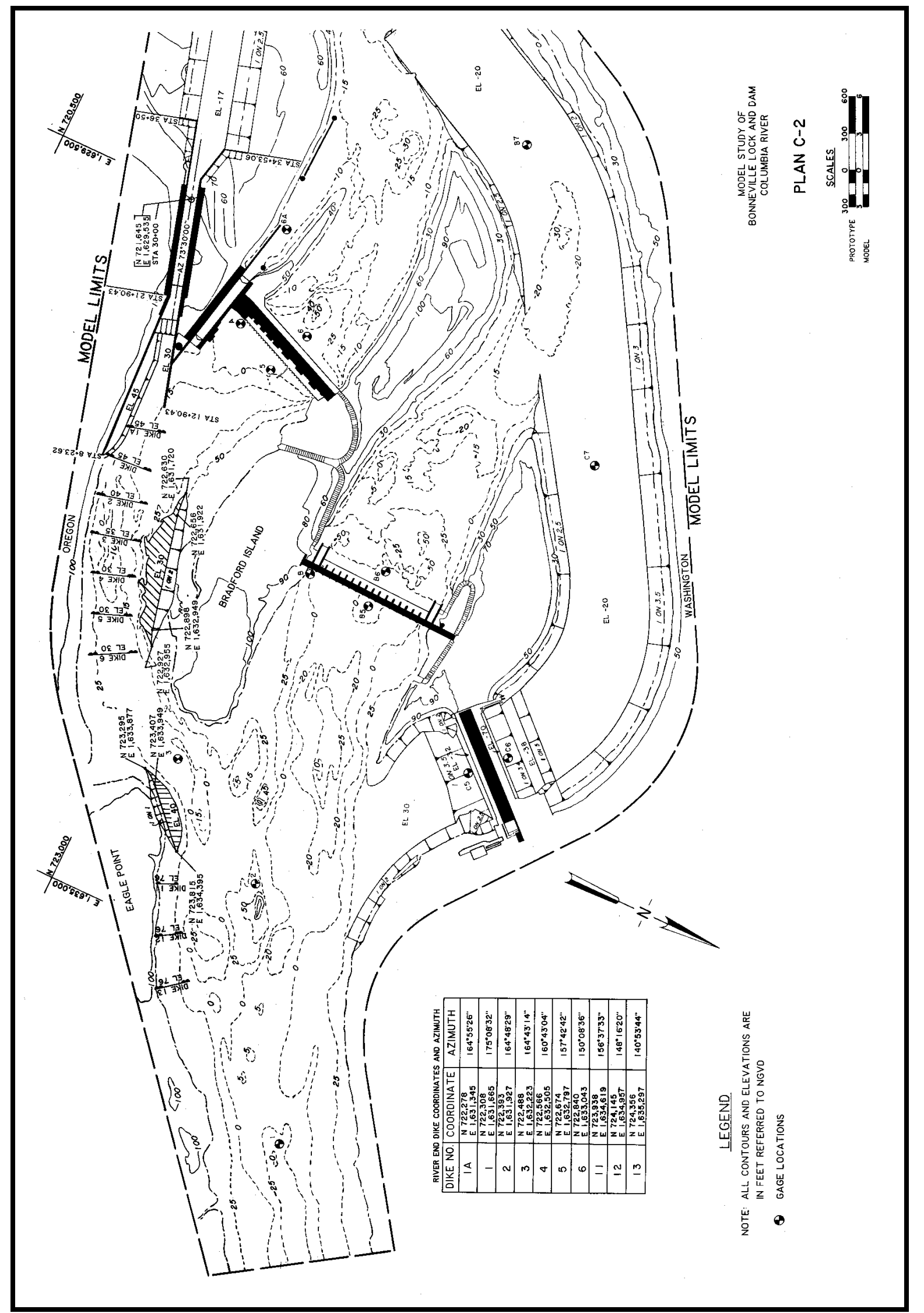

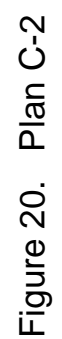




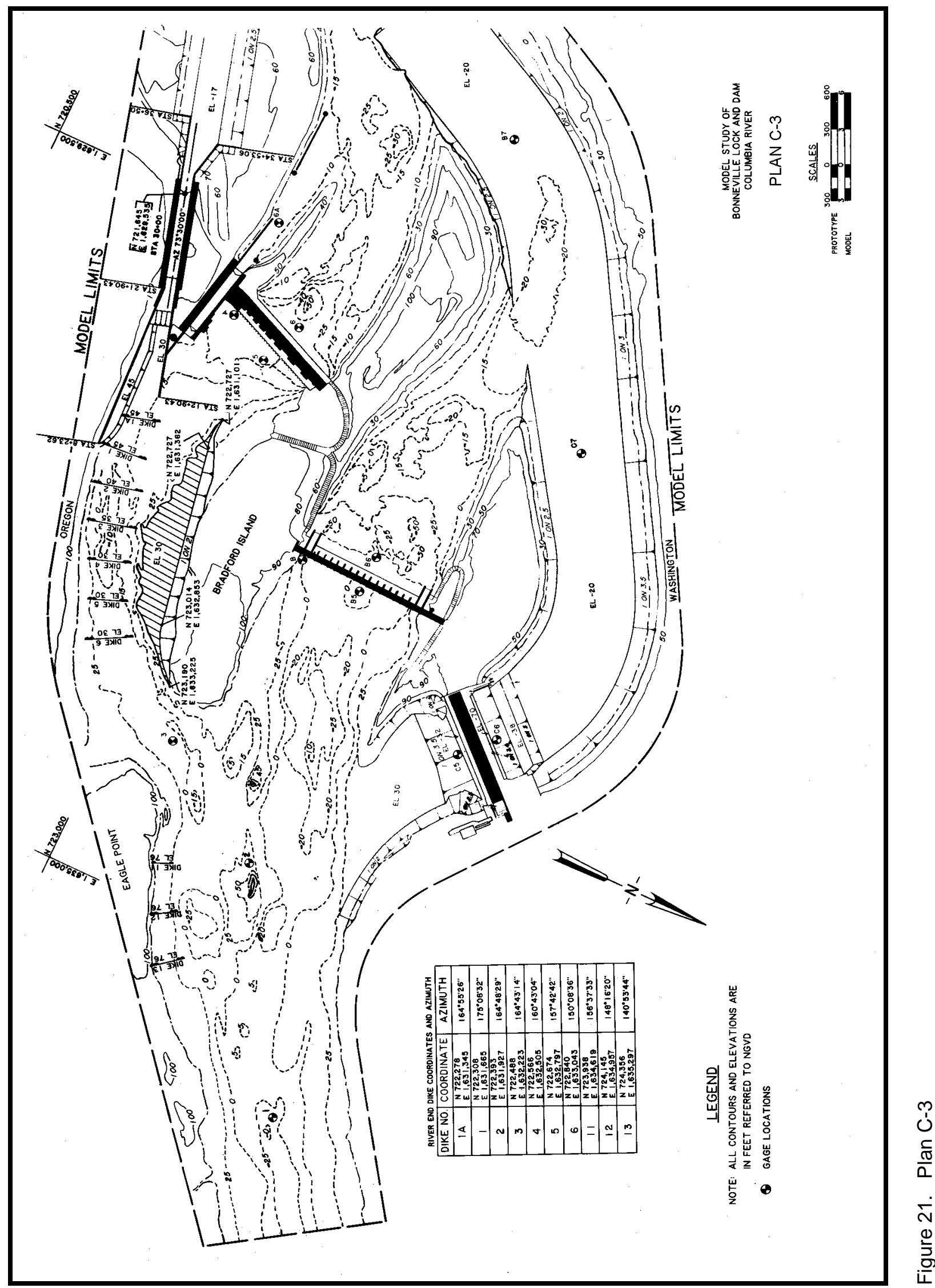




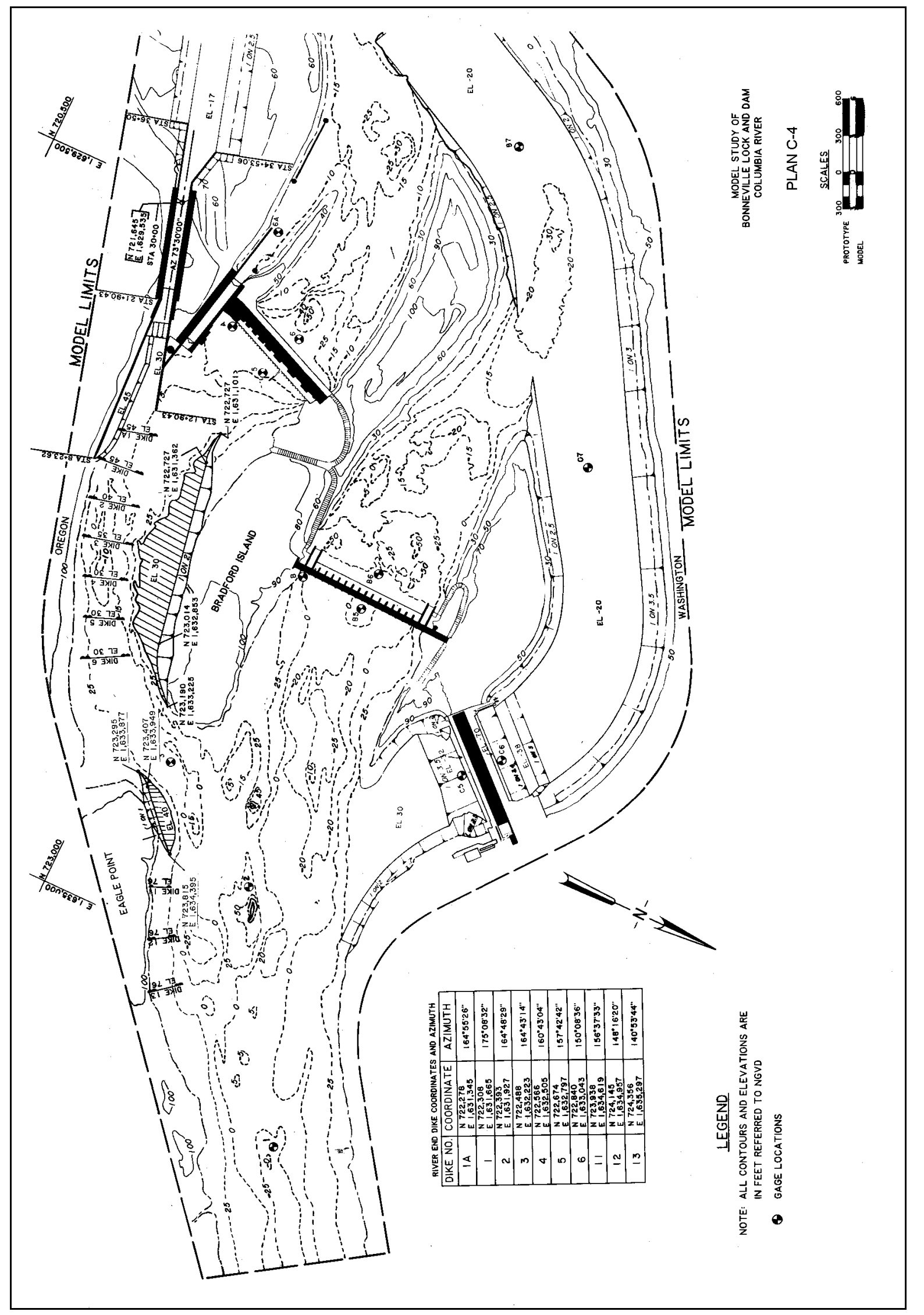

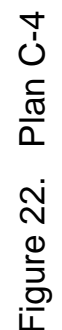




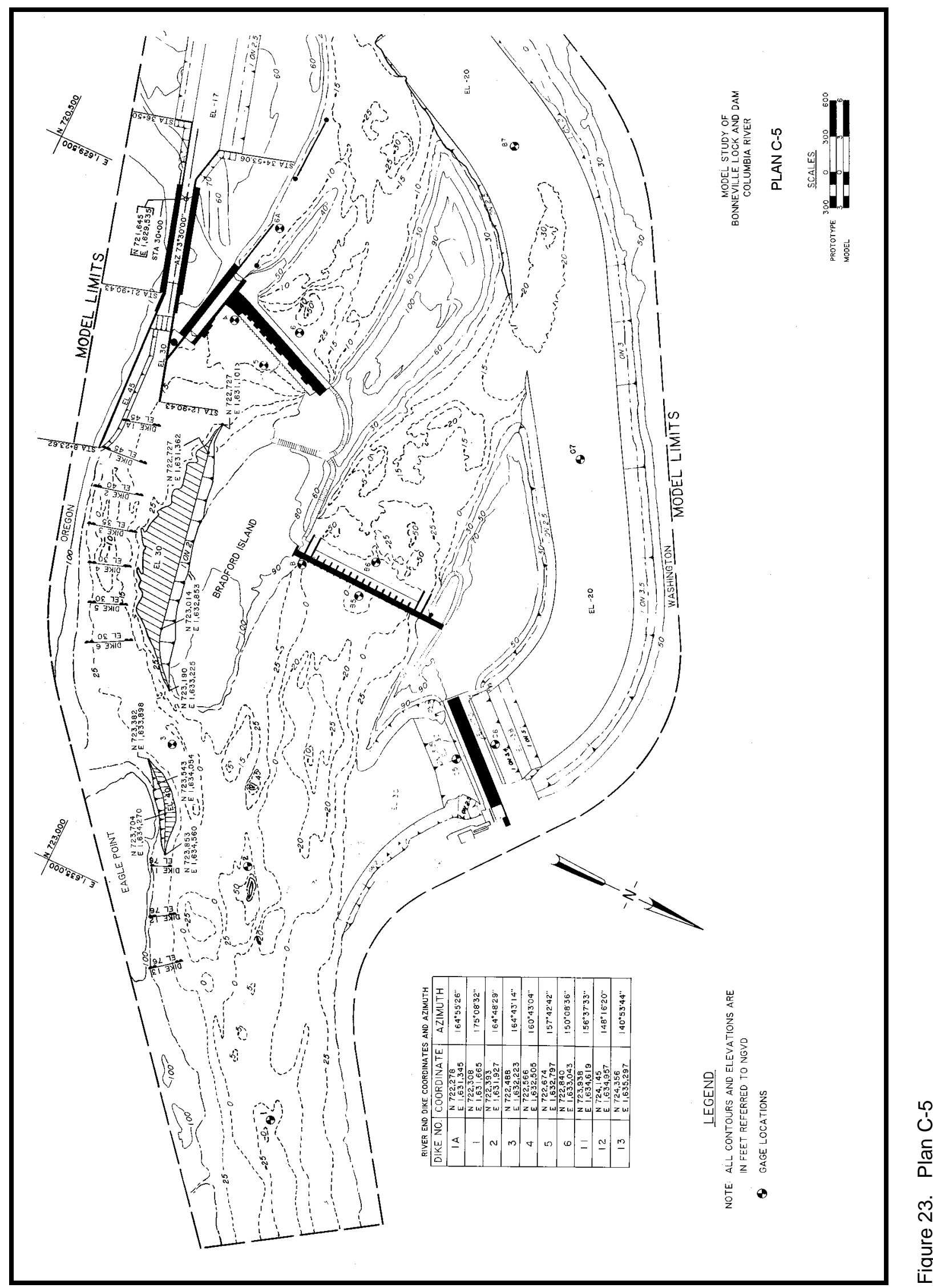




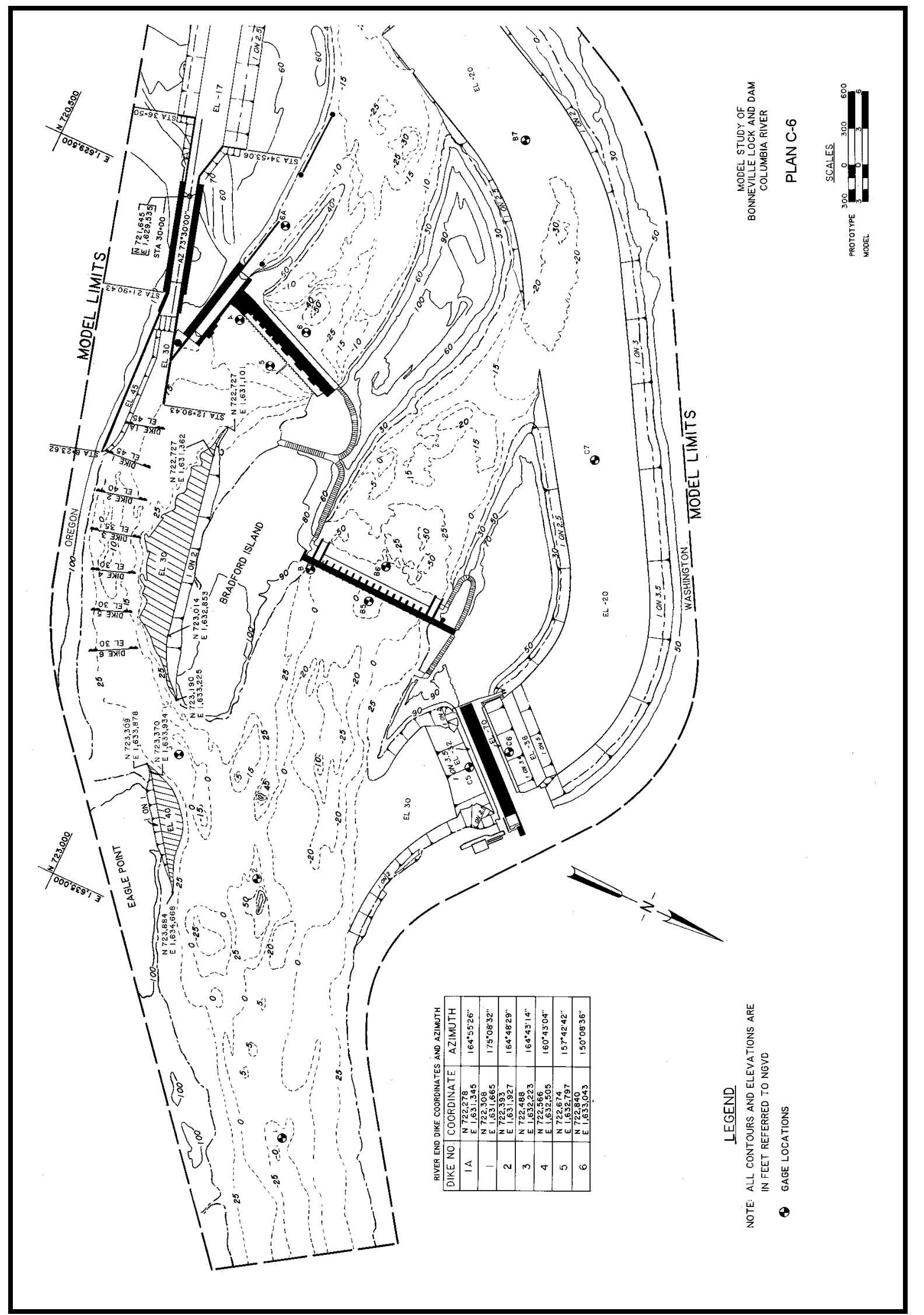

0
0
$\frac{1}{0}$
$\frac{0}{\alpha}$
$\dot{d}$
d
$\frac{0}{5}$
$\frac{0}{4}$ 


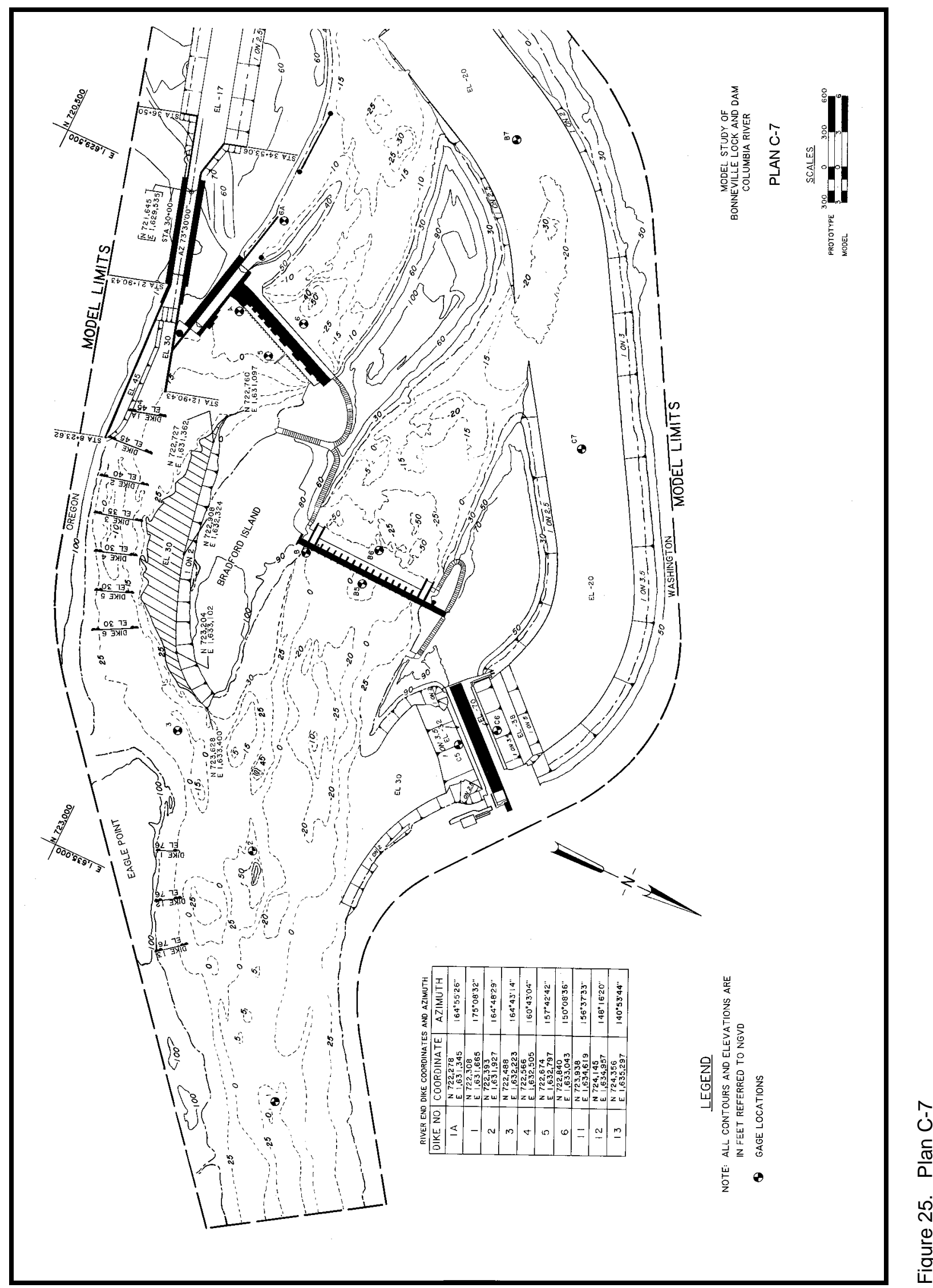




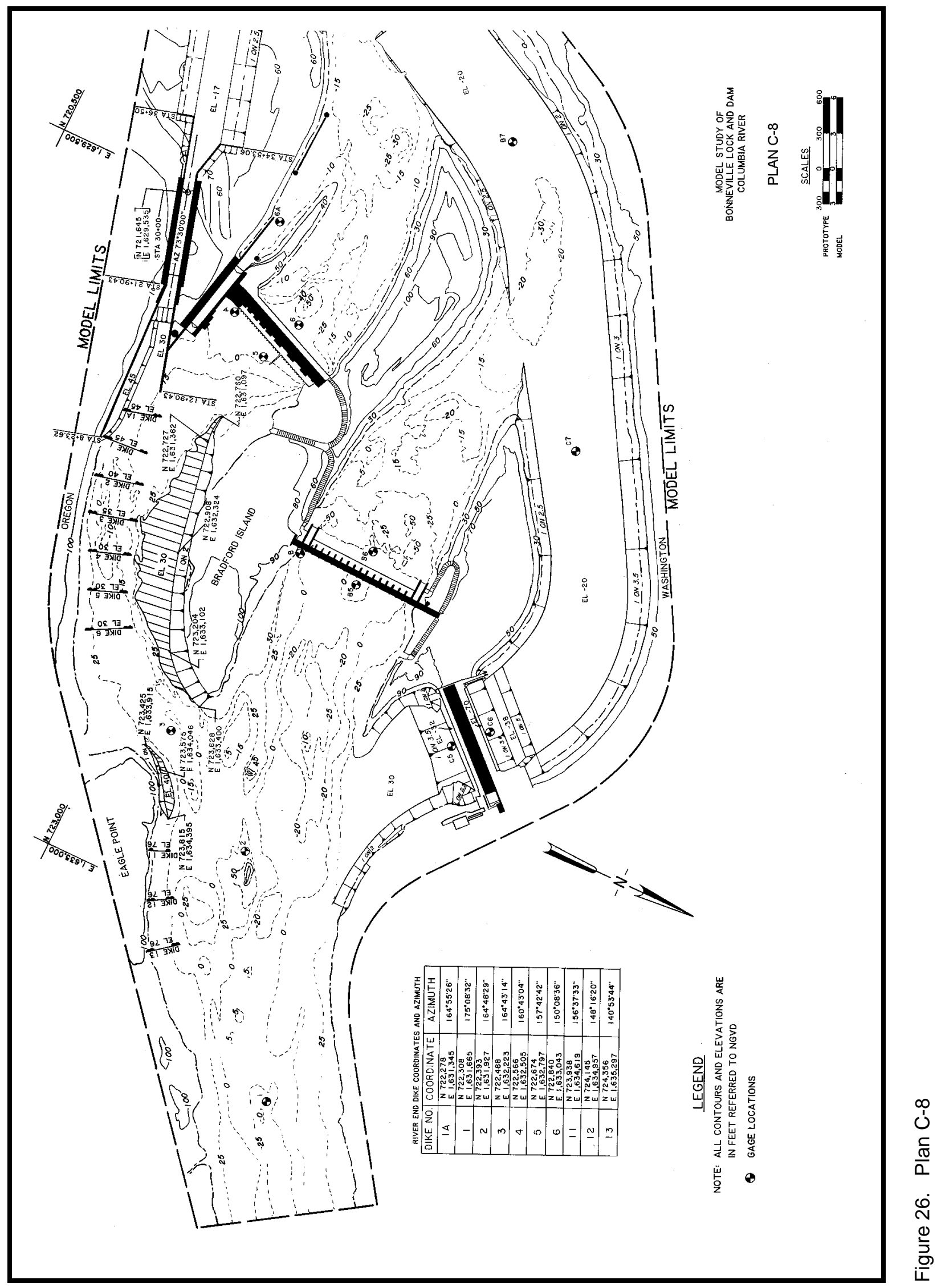

Chapter 3 Experiments and Results 


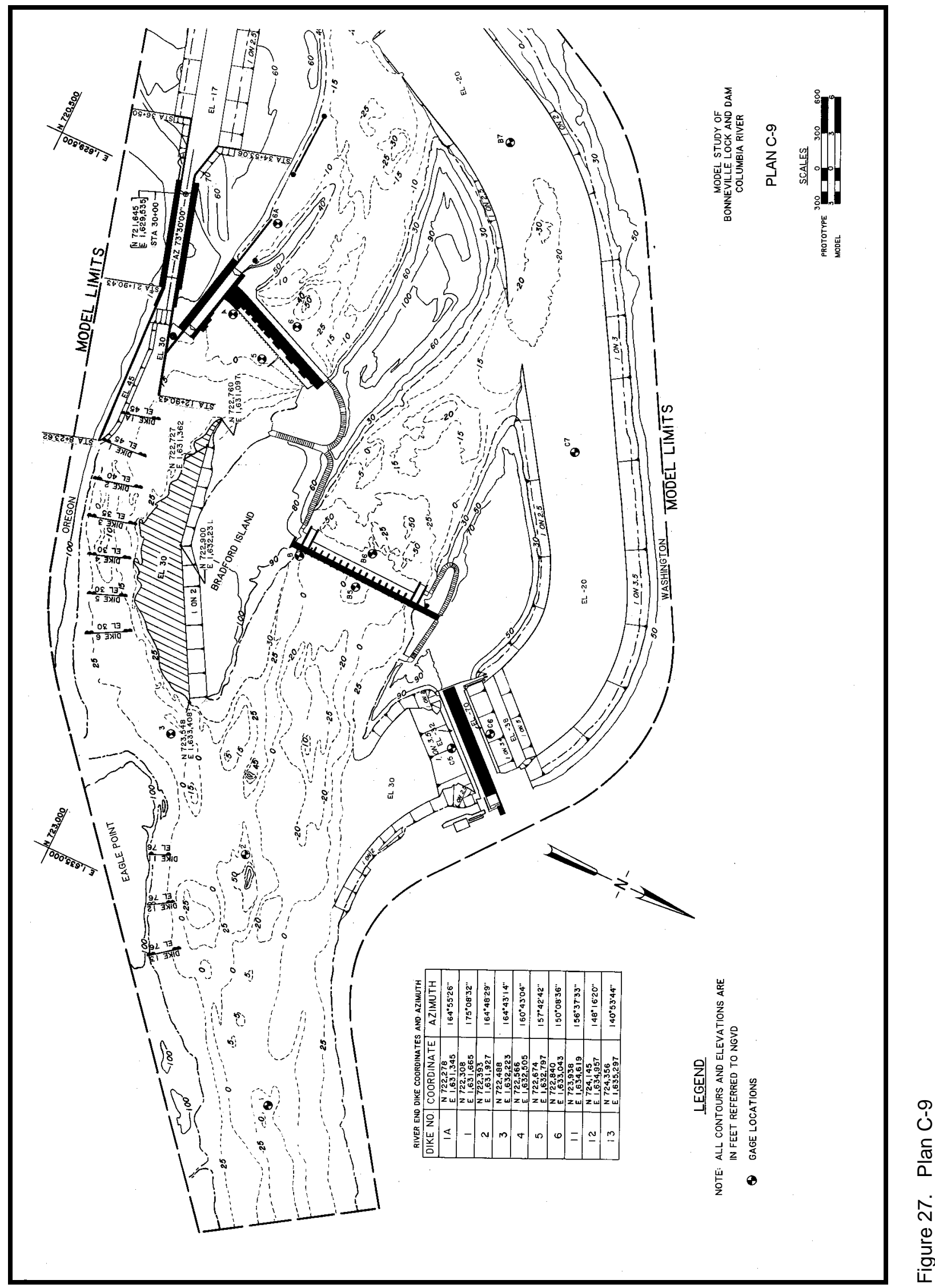


el 30.0. The coordinates of the revised Bradford Island excavation are shown in Figure 21.

Plan C-4 (Figure 22) was the same as Plan C-3, except Eagle Point was excavated landward about $150 \mathrm{ft}$ at el 40.0. The coordinates of the Eagle Point excavation are shown in Figure 22 and were the same as Plan C-2.

Plan C-5 (Figure 23) was the same as Plan C-4, except Eagle Point excavation was reshaped to better align with the river ends of the spur dikes. The coordinates of the realigned excavation are shown in Figure 23.

Plan C-6 (Figure 24) was the same as Plan C-5, except the three spur dikes upstream of Eagle Point were removed and the Eagle Point excavation was increased to about $200 \mathrm{ft}$ at el 40 .

Plan C-7 (Figure 25) was the same as Plan C, except the Bradford Island left bank excavation was increased by extending the excavation around the head of the island.

Plan C-8 (Figure 26) was the same as Plan C-7, except Eagle Point was excavated landward about $100 \mathrm{ft}$ at el 40.0 (same as C-1 and B-2).

Plan C-9 (Figure 27) was the same as Plan C, except the Bradford Island excavation was increased to what was considered the extreme limits at el 30. The coordinates of the excavation are shown in Figure 27.

\section{Results of experiments with Plans C through C-9}

Water-surface elevations. Water-surface elevations obtained with Plans C through C-2 are shown in Table 5. These data show the slope in water-surface elevations downstream of the dam was generally the same with all plans. However, the slope in water-surface elevations through the first powerhouse channel varied somewhat depending on the excavation schemes for Eagle Point and Bradford Island.

Current directions and velocities. Current directions and velocities obtained with Plans C through C-9 are shown in Plates 34-43. These data show the spur dikes upstream of Eagle Point improved the alignment of the currents in the vicinity of Eagle Point and the entrance to the first powerhouse channel while the Eagle Point excavation had little, if any, effect on the alignment of the currents in this area. The excavation of Bradford Island shown in Plans C-3 through C-6 reduced the velocity of the currents approaching the new lock about $1.0 \mathrm{fps}$ and reduced the outdraft near the upstream end of the guard wall. However, there was little effect on the angle of the currents approaching the guard wall. Excavation of the upstream end of Bradford Island, as shown in Plans C-7 and C-8, only influenced the currents in the immediate vicinity of the excavation. Measurements made with Plan C-9 (Plate 43) show a large clockwise eddy formed near the upstream end of Bradford Island and along the 
left bank of the island near the powerhouse. This is an indication that the excavation was oversized.

Navigation conditions. Navigation experiments indicated that a combination of spur dikes upstream of Eagle Point, excavation of Eagle Point, and excavation of Bradford Island would improve navigation conditions for tows entering and leaving the new lock. Plan C- 5 appeared to provide the best overall navigation conditions for tows entering and leaving the new lock. Downbound tows could drive along the river end of the spur dikes, drive the head of the tow close to Eagle Point, complete the "S" turn and align with the new lock without any major difficulties. The tow could start reducing speed about one to two tow lengths upstream of the guard wall and approach the wall at a safe speed. Upbound tows could maneuver the head of the tow away from the guard wall, align with the landside guide wall and drive upstream along the left descending bank. However, considerable time and power were required for the tow to maneuver the head of the tow away from the guard wall.

\section{Experiments with Plan D}

Plan C-5 was selected as the plan that provided the best overall performance within the guidelines for excavation of Eagle Point provided by the Portland District. Therefore, Plan C-5 is designated Plan D for full documentation purposes.

\section{Description}

Plan D (Figure 28) is the same as preliminary experiment Plan C-5 and is the same as the original design, except:

a. A system of seven submerged dikes in the deep part of the navigation channel approaching the new lock. The submerged dikes were spaced about $300 \mathrm{ft}$ apart with Dike 1 placed at sta 8+23.62. Dikes $2-6$ were placed upstream of Dike 1 and Dike 1-A was placed downstream of Dike 1. The crests of the dikes were at elevations 45, 45, 40, 35, 30, 30, and 30 for Dikes 1-A, 1, 2, 3, 4, 5, and 6, respectively. Locations, alignments, and elevations of the submerged dikes are shown in the coordinate table in Figure 28.

$b$. Three spur dikes were added along the left descending bank immediately upstream of Eagle Point. The dikes were constructed with side slopes of $1 \mathrm{~V}$ on $2.5 \mathrm{H}$ and a top elevation of 76.0. The position and alignment of the dikes are shown in the coordinate table in Figure 28.

c. Eagle Point was excavated landward about $100 \mathrm{ft}$ at el 40.0 and aligned with the river ends of the spur dikes. The coordinates of the Eagle Point excavation are shown in Figure 28.

d. Bradford Island was excavated landward about $350 \mathrm{ft}$ at el 30.0. 


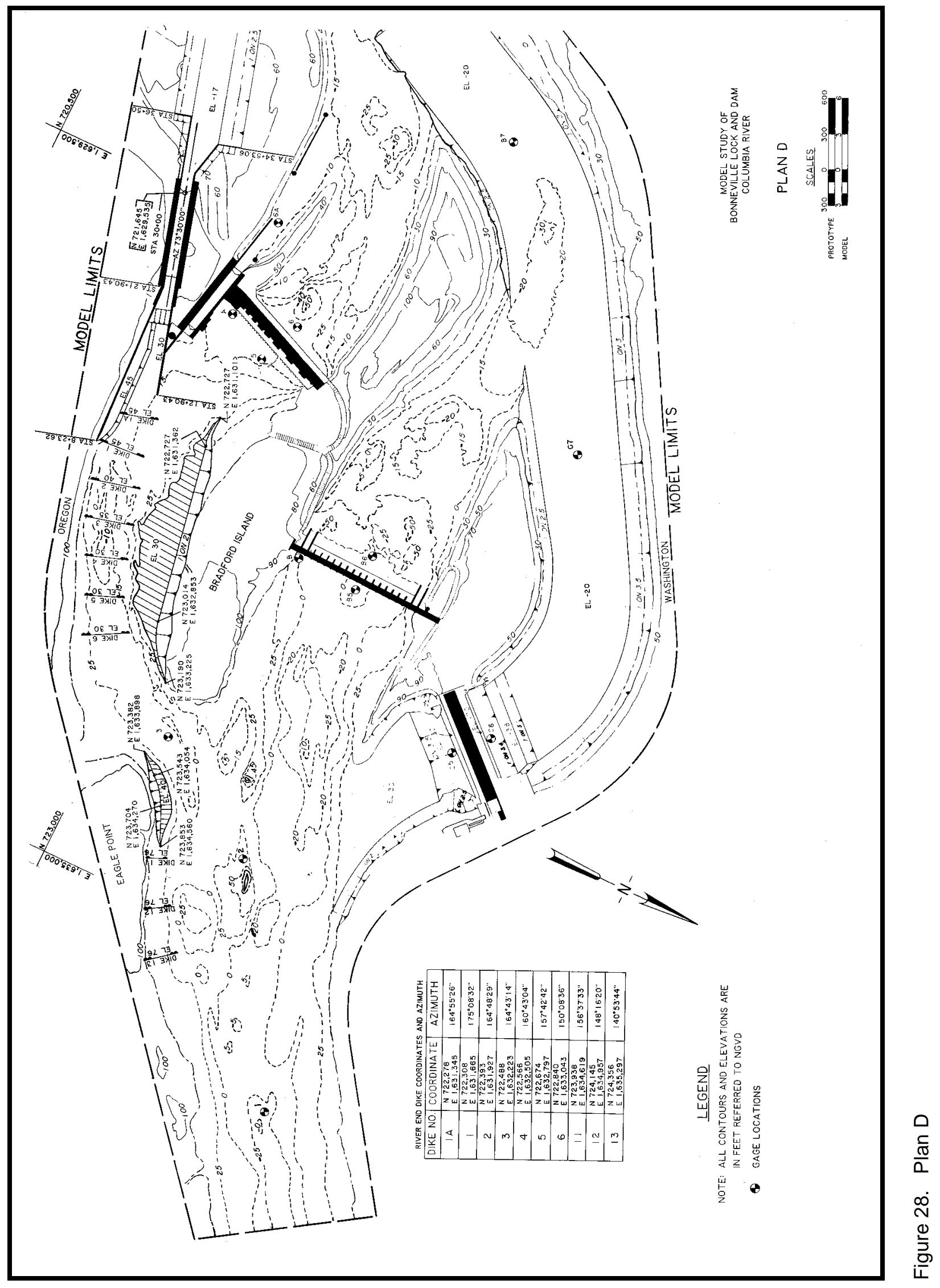

Chapter 3 Experiments and Results 


\section{Results of experiments with Plan D}

Current directions and velocities. Current directions and velocities obtained with Plan D are shown in Plates 44-49. These data show the currents are generally parallel with the left bank with maximum velocities that would affect a tow in the upstream lock approach varying from about 0.8 to $6.4 \mathrm{fps}$ near Eagle Point and about 0.9 to $6.3 \mathrm{fps}$ near the upper end of the guide wall for flows ranging from 70,400 to $660,000 \mathrm{cfs}$. Velocities near the end of the guide wall were highest at $335,000 \mathrm{cfs}$ and decreased somewhat with the higher flows. The submerged dikes in the approach to the lock, along with the excavation of Bradford Island, improved the current alignment into the lock approach, reduced the outdraft near the upper end of the guard wall, and made some reduction in the concentration of flow along the left bank upstream of the lock. The spur dikes reduced the size of the large eddy along the left bank just upstream of Eagle Point and improved flow conditions approaching Eagle Point, particularly during the higher flows.

Current directions and velocities measured with the magnetic velocity meter are shown in Plates 50 - 55. Measurements were made near the water surface, at mid-depth in the water column, and near the bottom of the channel. These measurements were made along the navigation channel where modifications were made so a comparison could be made to base conditions. These data show some difference in the direction and velocity of the currents compared to the float velocities and differences between measurements made at different depths through the water column.

Navigation conditions. Navigation conditions in the upstream approach to the new lock were improved considerably compared to conditions with the original design. Satisfactory and safe navigation conditions were obtained with all flows evaluated up to 485,000 cfs, provided downbound tows exercised caution in approaching Eagle Point. A downbound tow properly aligned with the currents passing within $300 \mathrm{ft}$ of Eagle Point can make the left turn downstream of the Point and approach the lock without difficulty with flows up to 335,000 cfs. With river discharges between 335,000 and 485,000 cfs flows, the distance riverward of Eagle Point from which a downbound tow could safely approach the lock was reduced to about $200 \mathrm{ft}$ or less depending on the angle of the tow with respect to the current alignment approaching Eagle Point. To ensure safe navigation conditions, a downbound tow should move as near to the ends of the spur dikes and Eagle Point as practicable. The greater the distance between Eagle Point and a downbound tow, the greater the angle of turn to the left a tow would have to make just downstream of the Point in order to properly approach the lock. The larger the angle of turn the tow has to make, the greater the exposure of the tow to crosscurrents and the greater the tendency for the tow to be rotated counterclockwise and miss the approach. Due to the relatively short distance between Eagle Point and the lock, it is important for a downbound tow to become properly aligned with the currents and to be close to the left bank as far upstream as possible to safely approach the lock. A tow properly aligned could make the turn, start reducing speed about one to two tow lengths upstream of the guard wall, and approach the wall at a safe speed. However, a tow 
misaligned or too far from the left bank would be in danger of colliding with the guard wall or missing the lock and going into the powerhouse. Due to the general bed configuration and the division of flow in the area approaching Eagle Point, flow conditions were very erratic with the 660,000-cfs flow. This resulted in unstable navigation conditions which would make it hazardous for downbound tows to attempt to approach the lock at this discharge. Upbound tows could maneuver the head of the tow away from the guard wall, align with the landside guide wall and drive upstream along the left descending bank with all flows evaluated provided they passed within $200 \mathrm{ft}$ of Eagle Point at the 660,000-cfs flow. However, considerable time and power were required for the tow to maneuver the head of the tow away from the guard wall.

\section{Experiments with Plan D-1}

\section{Description}

Plan D-1 (Figure 29) was the same as Plan D, except:

a. Three spur dikes upstream of Eagle Point were removed.

b. Excavation of Eagle Point was increased to about $180 \mathrm{ft}$ at el 40.0 .

\section{Results of experiments with Plan D-1}

Current directions and velocities. Current directions and velocities obtained with Plan D-1 are shown in Plates 56 - 61. These data indicate no significant changes in the maximum velocities which could affect navigation in the upstream approach to the lock compared to those obtained with Plan D. However, there was considerable improvement in the current alignment for flows above $200,000 \mathrm{cfs}$. These currents were generally straight from upstream of Eagle Point to some distance downstream of the Point. The maximum velocities which could affect the movement of a tow approaching the lock ranged from about 0.8 to $6.8 \mathrm{fps}$ near Eagle Point and 0.8 to $5.0 \mathrm{fps}$ near the upper end of the guide wall with flows from 70,400 to $660,000 \mathrm{cfs}$. Velocities near the end of the guide wall were highest at 335,000 cfs and decreased somewhat with the higher flows. The additional cut on Eagle Point with this plan further reduced the size of the eddy above the Point.

Navigation conditions. Straightening the currents in the vicinity of Eagle Point produced navigation conditions which were considerably better than results obtained with Plan D. Downbound tows properly aligned upstream of Eagle Point could drift into the lock with the lower flows and could approach the lock with all flows evaluated without difficulty. However, the unstable flow conditions with the 660,000-cfs flow upstream of Eagle Point were not completely eliminated and could still adversely affect a tow moving downstream $300 \mathrm{ft}$ or further from the left bank when approaching Eagle Point. Upbound 


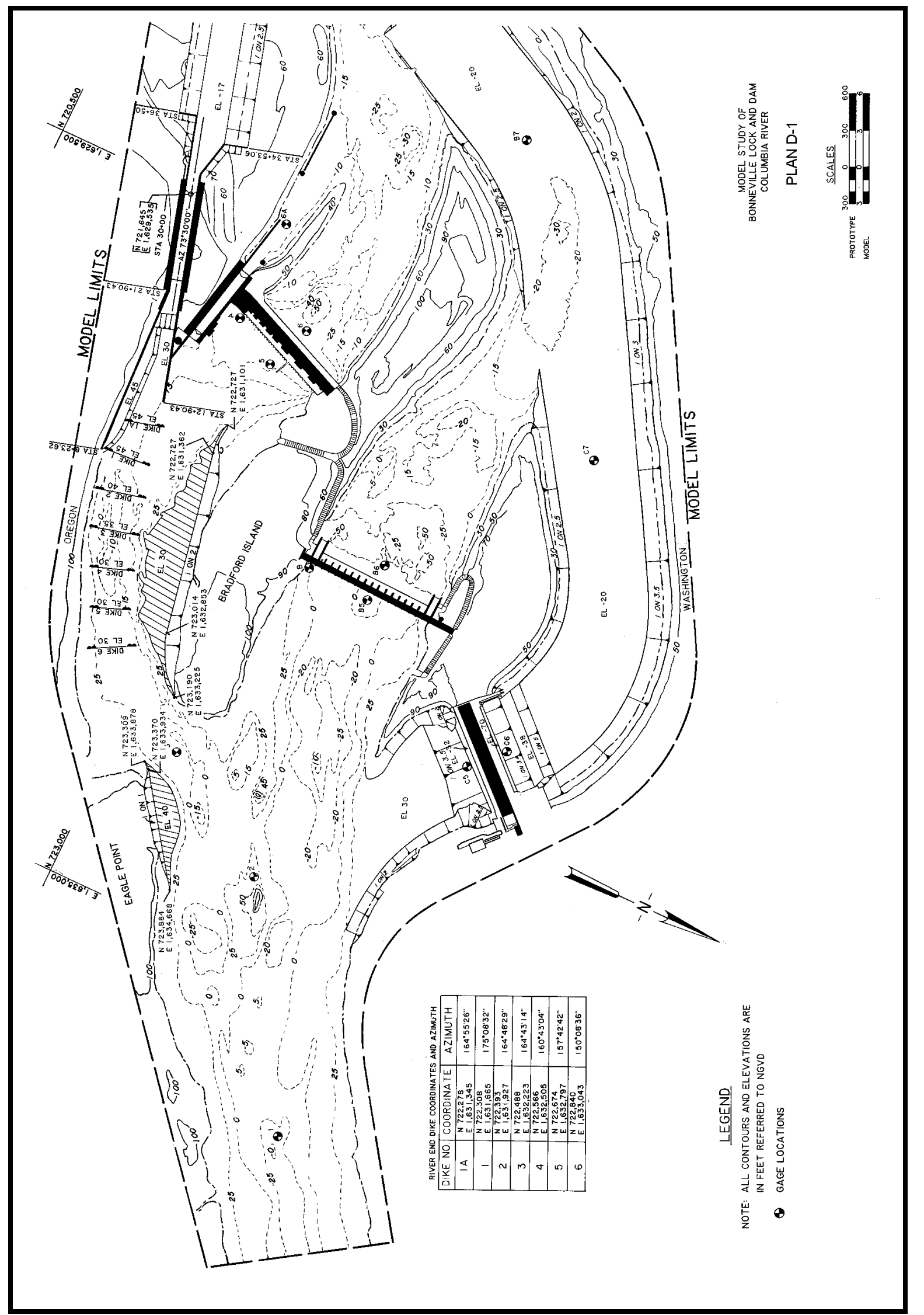

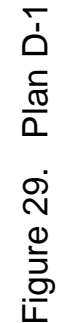


tows with sufficient power to maintain headway and steerage could maneuver the head of the tow away from the guard wall, align with the landside guide wall and drive upstream along the left descending bank without any major difficulty with all flows evaluated. However, considerable time and power were required for the tow to maneuver the head of the tow away from the guard wall.

\section{Experiments with Plan D-2}

\section{Description}

Plan D-2 (Figure 30) was the same as Plan D-1, except :

a. Spur Dike 11, upstream of Eagle Point, was removed.

$b$. The floating guard wall was extended upstream about $100 \mathrm{ft}$ and a 50-ft-diam guard cell was placed at the upstream end of the wall.

c. The berm along the landside guide/retaining wall was raised to el 51.0.

d. A berm with top el 30 was added around the guard wall cell at the upstream end of the wall.

e. The upstream guide/retaining wall was shortened to sta $10+29$ and the upstream end was angled toward the bank to provide a smooth transition into the bank.

\section{Results of experiments with Plan D-2}

Current directions and velocities. Current directions and velocities measured with Plan D-2 are shown in Plates 63 - 67. These data show the current direction and velocities were generally the same as with Plan D. Removing spur Dike 11 had little or no effect on the currents in the vicinity of Eagle Point. The extended guard wall tended to intercept more flow and raising the berm along the guide wall to el 51.0 appeared to reduce the angle at which the current approached the guard wall. Current velocities were generally the same.

Navigation conditions. Navigation conditions were generally the same as with Plan D except downbound tows approaching Eagle Point could start the turn into the first powerhouse channel farther upstream and drive the head of the tow closer to Eagle Point without Dike 11 in place. This improved navigation conditions at Eagle Point slightly. Extending the guard wall provided tows more protection from the currents moving across the approach toward the powerhouse. Downbound tows could land on the guard wall at a safe speed without any major difficulties. The tow could start reducing speed about one to two tow lengths upstream of the guard wall and approach the wall at a safe speed. Due to the 


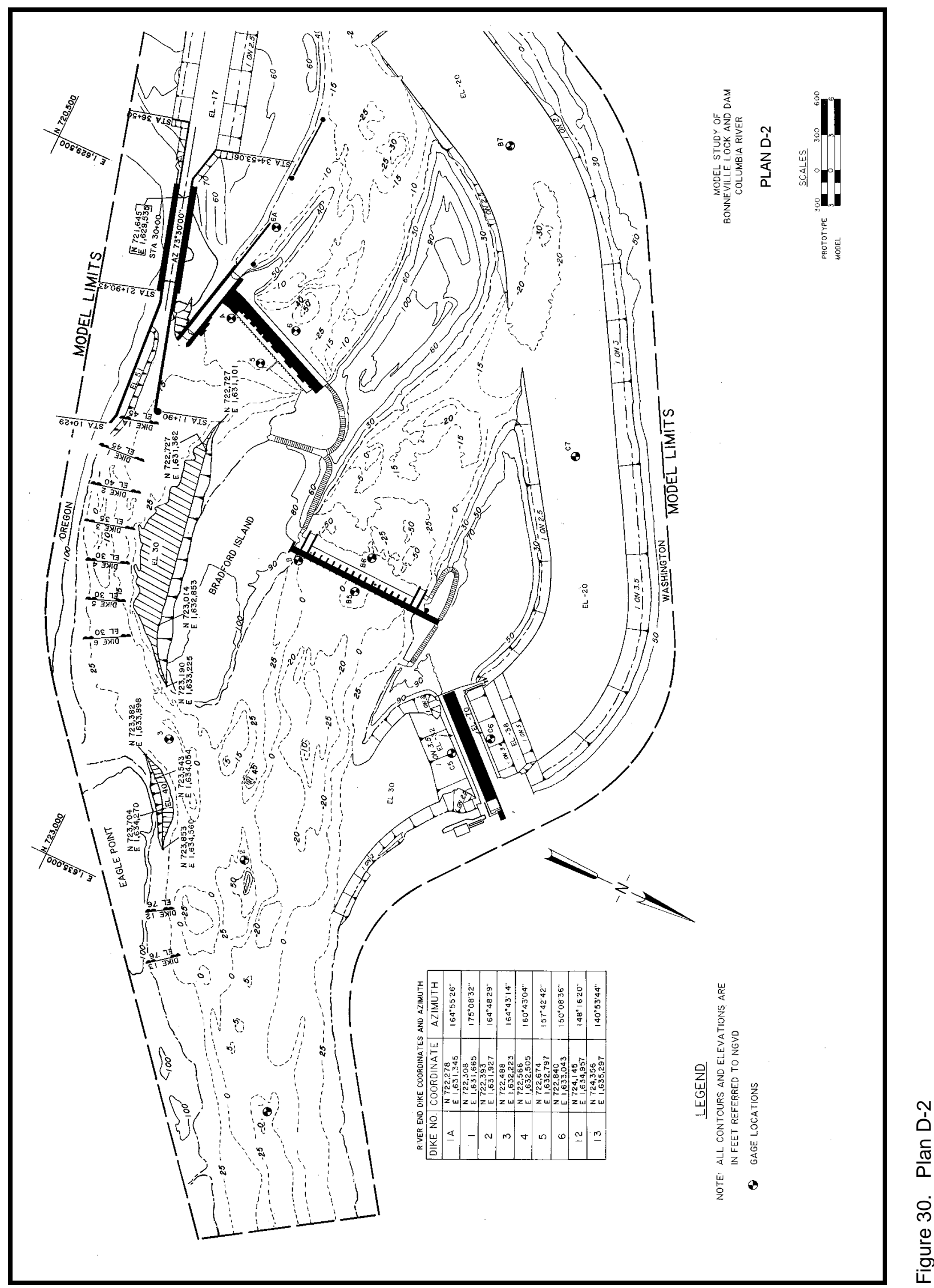


longer guard wall, upbound tows could maneuver the head of the tow away from the guard wall with less effort. However, considerable time and power were still required for the tow to maneuver the head of the tow away from the guard wall.

\section{Experiments with Plan E}

Portland District requested experiments to determine if and at what elevation spoil from the excavation for the new lock could be placed in the submerged dike field upstream of the lock. Preliminary experiments were conducted with various elevations of fill between the dikes and various elevations of dikes. These preliminary experiments showed that changing the elevations of the dikes in the dike field would adversely affect navigation conditions. These experiments also showed that spoil could be placed between the dikes up to el 20 without adversely affecting navigation conditions.

\section{Description}

Plan E (Figure 31) is the same as Plan D-2, except:

a. Fill to el 20 was placed between submerged Dikes 1-A, 1, 2, 3, 4, 5, and 6.

$b$. Fill was placed in the lock forebay to el 43.0 ( $10 \mathrm{ft}$ below the bottom of the floating guard wall at normal pool el 74.0).

c. The upstream $200 \mathrm{ft}$ of the floating guard wall was closed to simulate a solid wall.

\section{Results of experiments with Plan E}

Current directions and velocities. Current directions and velocities obtained with Plan E are shown in Plates 68 - 73. These data indicate the current pattern was generally the same as with Plan D-2. The currents are generally parallel to the left bank, with maximum velocities that would affect a tow in the upstream lock approach varying from about 1.2 to 6.4 fps near Eagle Point and about 0.8 to 4.6 fps near the upper end of the guide wall for flows ranging from 70,400 to $660,000 \mathrm{cfs}$. These data indicate that placing the fill between the submerged dikes improved the alignment of the current slightly in the immediate lock approach. The currents were better aligned with the guard wall compared to Plan D-2 and the currents tended to impact the guard wall closer to the lock chamber.

Navigation conditions. Navigation conditions were generally the same for tows entering and leaving the new lock as with Plan D-2, except for downbound tows approaching the guard wall. Experiments indicated downbound tows could 


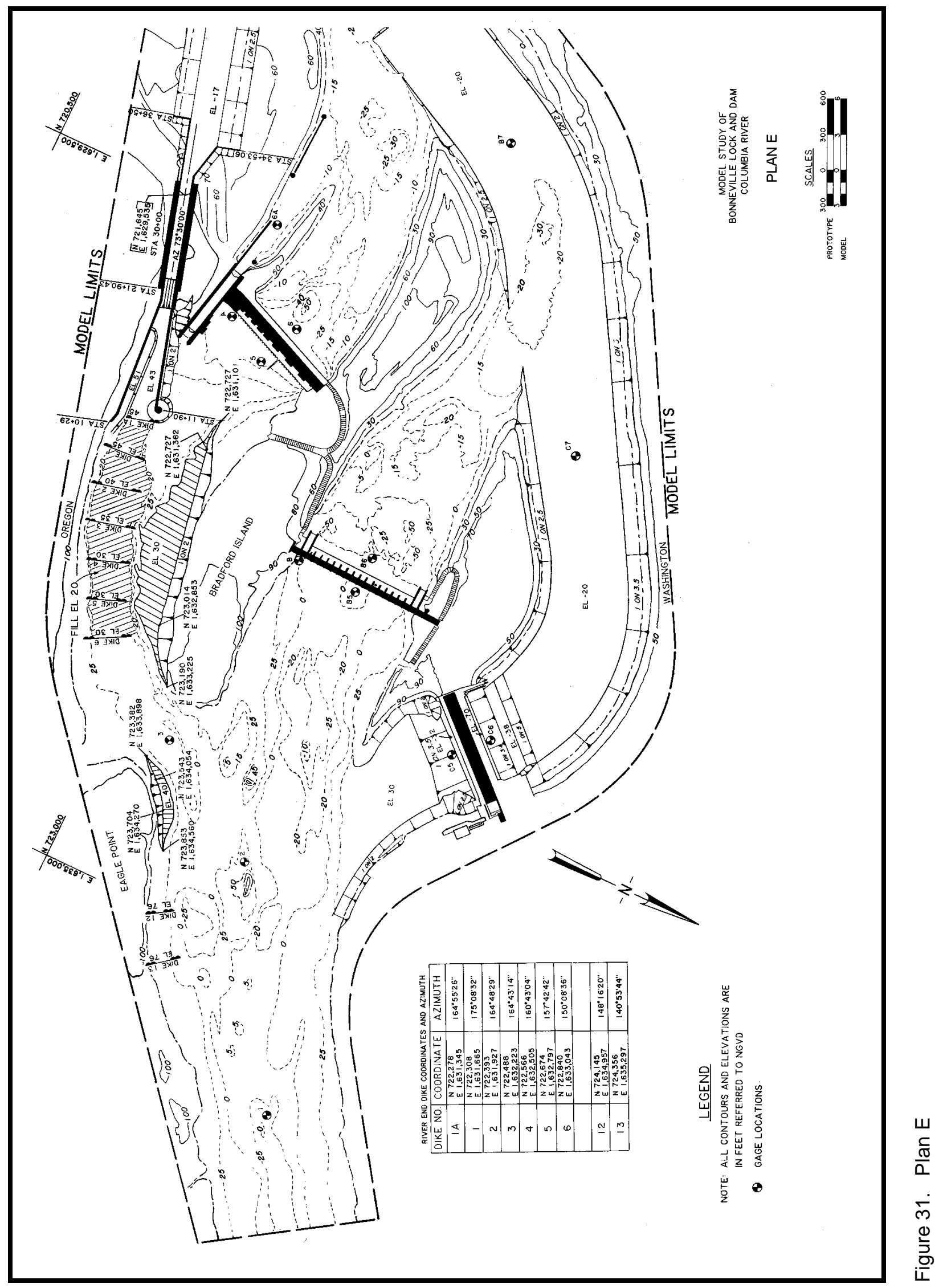


approach the guard wall with a slightly lower angle of approach and land on the wall closer to the lock chamber than with Plan D-2.

\section{Experiments with Plan F}

\section{Description}

Plan F (Figures 32 and 33 and Photos 5 and 6) was similar to Plan D and was the same as existing conditions, except for the following major changes or components:

$a$. The upstream landward wall of the existing lock was removed.

b. An 86-ft-wide by 675-ft-long replacement lock was located landward of the existing lock.

c. An 810 -ft-long floating guard wall drafting $30 \mathrm{ft}$ with 18 -ft-wide by 5 -ftdeep fish ports (Figure 33).

d. A 64-ft by 83-ft clover-leaf cell at the upstream end of the guard wall.

$e$. A landward retaining wall, with a 50-ft-wide berm at el 51, extending about 1,100 ft upstream from the lock and angled about $12 \mathrm{deg}$ landward.

f. The lock forebay at el 34, except in the vicinity of the lock filling ports.

g. A $250-\mathrm{ft}$ bottom width lock canal at el -17 with $1 \mathrm{~V}$ on $2.5 \mathrm{H}$ side slopes; the right descending canal bank was excavated on a $296-\mathrm{ft}$ radius beginning at sta $48+00$ to provide a wider entrance to the canal (see Photo 6).

$h$. A 50-ft-diam protection cell was placed along the left bank of the canal near the river channel.

$i$. A fill with top el 81.0 was placed along the left bank upstream of Eagle Point. A berm located near the upstream end of the fill with top el 51.0 allowed tows to use the existing mooring dolphins. The fill was designated Goose Island (see Photo 5).

j. Eagle Point was excavated landward about $90 \mathrm{ft}$ at el 40.0.

k. Bradford Island was excavated landward about $350 \mathrm{ft}$ at el 30.0 .

1. A system of seven submerged dikes in the deep part of the navigation channel approaching the new lock. The submerged dikes were spaced about $300 \mathrm{ft}$ apart with Dike 1 placed at sta 8+23.62. Dikes 2 - 6 were placed upstream of Dike 1 and Dike 1-A was placed downstream of 


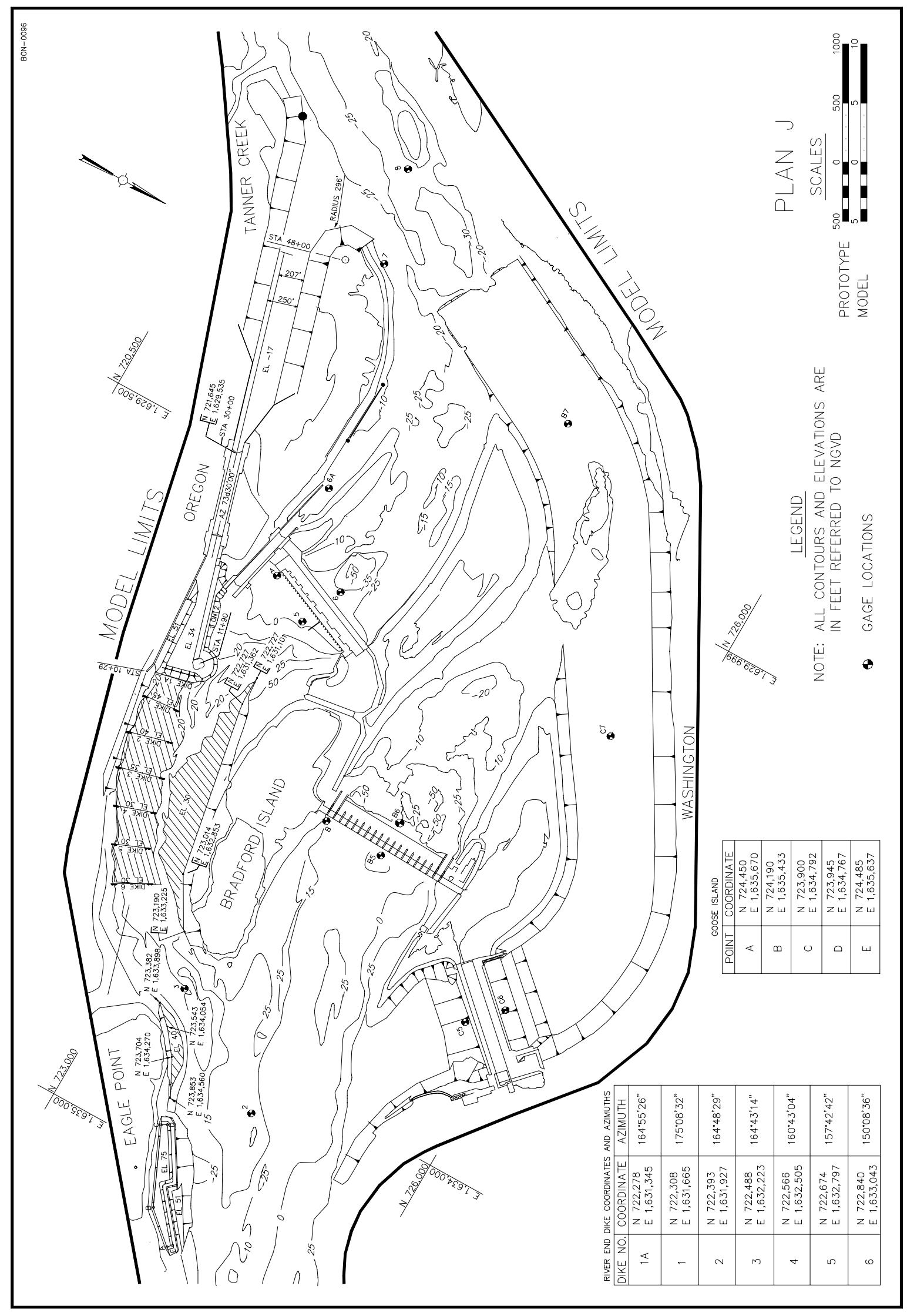

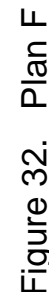




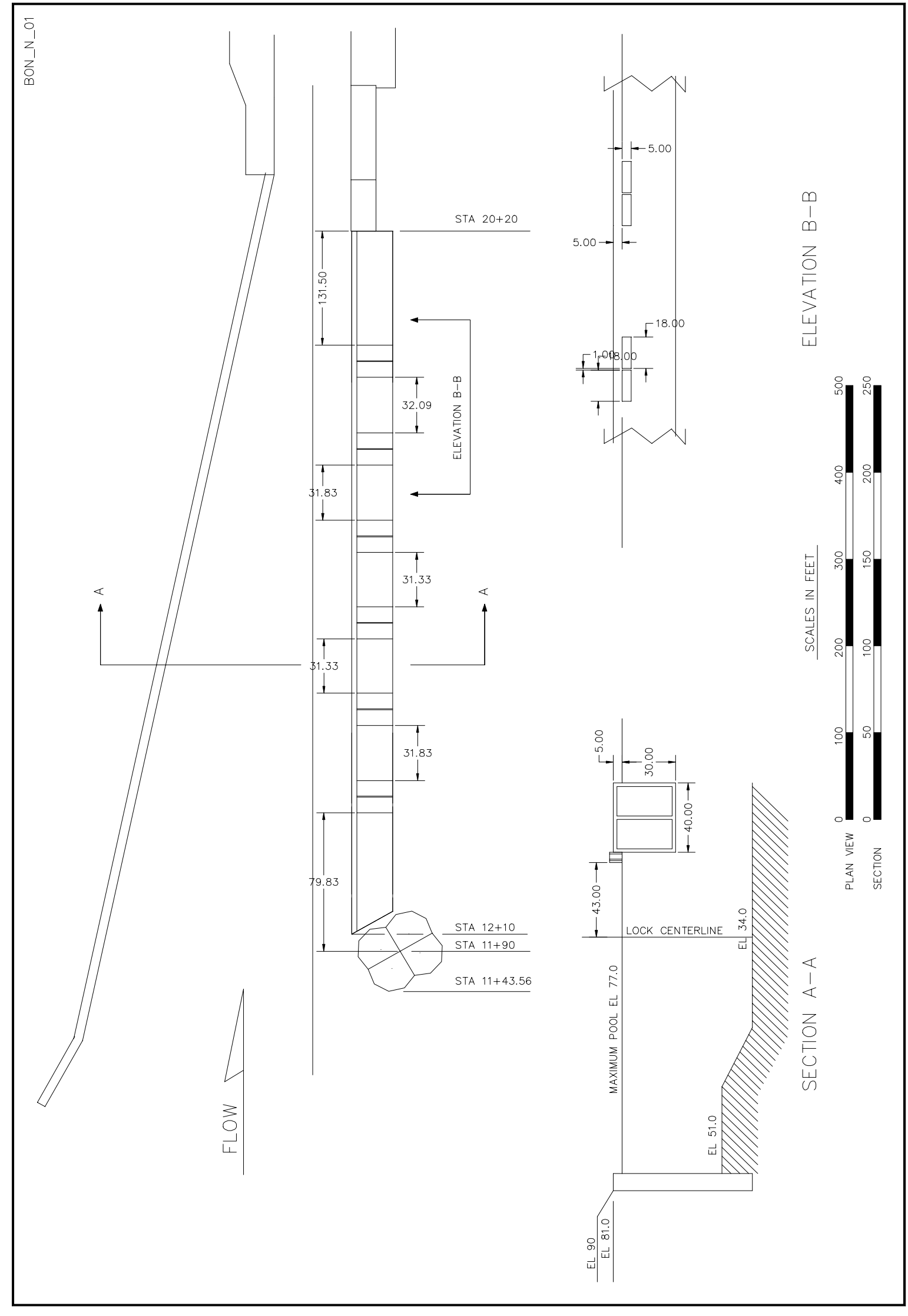

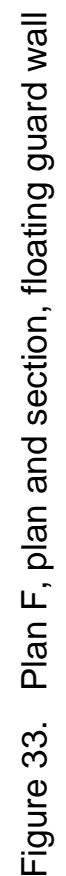


Dike 1. The crests of the dikes were at el 45, 45, 40, 35, 30, 30, and 30 for Dikes 1-A, 1, 2, 3, 4, 5, and 6, respectively.

$m$. A fill with top elevation of 20.0 was placed between the submerged dikes 1 -A, 1, 2, 3, 4, 5, and 6 .

$n$. A fill with top elevation 90.0 was placed along the left bank immediately upstream of the new retaining wall to provide additional area for new railroad tracks.

\section{Results of experiments with Plan F}

Water-surface elevations. Water-surface elevations obtained with Plan F are shown in Table 6. These data show the slope in water-surface elevations was generally the same as with the original design.

Current directions and velocities. Current direction and velocity data shown in Plates 74 - 81 and confetti shown in Photo 7 indicate the current generally parallels the left bank with a separation of flow occurring near the riverward ends of the submerged dikes. The currents approach the floating guard wall at a maximum angle of about $20 \mathrm{deg}$. The maximum velocities that would affect a tow approaching the lock varied from about 0.9 to 6.4 near Goose Island and Eagle Point and about 0.5 to 5.0 near the upper end of the guide wall for riverflows ranging from 70,400 to 660,000 cfs. The submerged dikes in the approach to the lock, along with the excavation of Bradford Island and Eagle Point, improved the alignment of the current in the new lock approach, reduced the outdraft near the upper end of the guard wall, and somewhat reduced the concentration of flow along the left bank upstream of the lock as compared to the original design. Goose Island reduced the size and intensity of the large eddy along the left bank immediately upstream of Eagle Point and improved flow conditions approaching Eagle Point, particularly during the higher riverflows. The currents near the downstream end of the lower lock canal generally align parallel to the left bank of the river channel; however, due to the alignment of the lower lock canal, the currents move past the entrance to the canal at an angle (Photo 8). A large low-velocity eddy formed in the canal entrance with all flows tested. With the 142,400-cfs flow, when the first powerhouse was discharging $140,000 \mathrm{cfs}$, the eddy extended into the river channel and upstream along the bank. The maximum velocity of the currents affecting a tow entering or leaving the canal varied from about 3.2 to $10.6 \mathrm{fps}$ near the entrance of the canal and about 3.8 to 14.2 fps near Tanner Creek with riverflows ranging from 70,400 to 660,000 cfs.

Navigation conditions. Navigation conditions in the upstream approach to the new lock were improved considerably compared to conditions with the original design. Satisfactory and safe navigation conditions were obtained with all riverflows tested up to 485,000 cfs, provided downbound tows exercise caution in approaching Eagle Point and the submerged dikes. A downbound tow properly aligned with the currents passing within $300 \mathrm{ft}$ of Eagle Point can make 
the left turn downstream of the point and approach the lock without difficulty with riverflows up to 335,000 cfs (Photo 9). With riverflows between 335,000 and 485,000 cfs, the distance riverward of Eagle Point from which a downbound tow could safely approach the lock was reduced to about $200 \mathrm{ft}$ or less depending on the angle of the tow with respect to the current alignment as it approached Eagle Point. To ensure safe navigation conditions, a downbound tow should move as near Goose Island and Eagle Point as practicable. The greater the distance between Eagle Point and a downbound tow, the greater the angle of turn to the left a tow would have to make just downstream of the Point in order to properly approach the lock. The larger the angle of turn the tow has to make, the greater the exposure of the tow to crosscurrents and the greater the tendency for the tow to be rotated counterclockwise and miss the approach. Due to the relatively short distance between Eagle Point and the lock, it is important for a downbound tow to become properly aligned with the currents and to be close to the left bank and over the submerged dike field as far upstream as possible to safely approach the lock. A tow misaligned or too far from the left bank would be in danger of colliding with the guard wall or missing the lock and going into the powerhouse. Due to the general bed configuration and the division of flow in the area approaching Eagle Point, flow conditions were very erratic with the 660,000-cfs riverflow. This resulted in unstable navigation conditions which could make it hazardous for downbound tows to attempt to approach the lock at this discharge.

Upbound tows with sufficient power to maintain headway and steerage could leave the lock and move through the reach without any major difficulty with all flows tested, provided they exercise caution passing Eagle Point with the higher riverflows (Photo 10). During periods when the first powerhouse is discharging $140,000 \mathrm{cfs}$, upbound tows should exit the lock forebay along the landward guide wall and the left descending bank. Tows leaving the forebay along the floating guard wall would be in danger of being rotated around the upstream end of the wall. There was some indication that with the higher first powerhouse discharges, tows may experience some difficulties maneuvering in the lock forebay to exit along the landward guide wall.

Satisfactory and safe navigation conditions were obtained in the downstream approach to the new lock with all riverflows tested up to 485,000 cfs, provided tows exercise caution entering and leaving the downstream lock canal. Downbound tows could exit the downstream lock canal without major difficulties with riverflows up to 335,000 cfs (Photo 11). As the riverflow increased to $335,000 \mathrm{cfs}$, there was a tendency for the tow to be moved downstream toward the protection cell along the left bank of the canal as the tow moved into the river channel. However, tows could move along the right bank of the lock canal and enter the river channel well upstream of the protection cell. As the riverflow increased to $660,000 \mathrm{cfs}$, the tendency for a downbound tow to be moved toward the protection cell increased and conditions could become hazardous for tows leaving the lock canal. Navigation conditions for upbound tows approaching the new lock were satisfactory with riverflows up to $335,000 \mathrm{cfs}$, provided the tows exercise some caution maneuvering to enter the lock canal (Photo 12). The right turn from the river channel, where the currents are parallel to the river channel, 
into the slack water lock canal requires the tow to move upstream of the protection cell along the left bank of the river channel, reduce speed, and use the currents to move the head of the tow into the lock canal. The large eddy that formed along the left bank line of the river channel with the 142,400-cfs riverflow, could increase the maneuvering required for the tow to enter the canal. As the riverflow increases to $660,000 \mathrm{cfs}$, the high velocity of the currents makes the turn into the lock canal more difficult, resulting in conditions that could be hazardous for navigation.

Experiments were conducted to evaluate navigation conditions for tows entering and leaving the lock with barges tied up at the mooring facility and approaching the moorage. Experiments were also conducted to determine if barges could be tied up along the right bank between the moorage facility and the entrance of the canal. The video tracking system was used to record the path, angle of the tow relative to the centerline of the canal, and the speed of tows entering and leaving the lock canal. The speed and angle of the tow are reported for selected stations along the canal as shown in Plate 82. Data shown in Plates 83 - 86 indicate tows could enter and leave the lower lock canal with barges tied up at the moorage facility without any major difficulties or increased maneuvering. With a total riverflow of 485,000 cfs, downbound tows were required to drive toward the right bank of the canal and enter the river channel along the right bank of the canal to clear the canal and the protection cell along the left bank of the canal (Plate 87). With the 485,000-cfs total riverflow, upbound tows were required to drive the head of the tow in close to the right bank of the canal, allow the current to move the head of the tow into the canal along the right bank, and drive toward the left bank to align with the lock (Plate 88). This maneuver could not be safely executed with either the 70,000or 485,000-cfs riverflows when barges were moored along the right bank downstream of the moorage facility (Plates 89 and 90). Upbound tows could enter the lock canal, approach the moorage facility at a safe speed, and dock with all riverflows evaluated (Plates 91 - 95).

Point Velocities. Point velocities were measured near the water surface, at mid-depth, and near the channel bottom with a range of riverflows to provide detailed velocity data for determining the effects the changes in current alignment and velocities and eddies may have on the migration of fish (Plates 96 - 101).

Lock Emptying Experiments. Experiments were conducted to measure surges in water-surface elevations and the velocity of the currents in the downstream lock canal at selected locations (Plate 102). The purpose of the experiments was to evaluate the effects of lock emptying on a tow tied off and waiting at the moorage facility immediately downstream of the new lock along the right bank of the canal. Allowing tows to wait at the moorage facility for a downbound tow to clear the new lock would decrease the transit time through the project. Surges were recorded during lock emptying with two heads and with and without barges being moored at the facility. Data measured during the experiments are shown in Plates 103 - 114. These data show surges in watersurface elevations measured without barges at the mooring facility (Plates 103 
and 104) were generally the same as with the original design. These data show that a maximum change in water-surface elevation of approximately $1.5 \mathrm{ft}$ occurred with the maximum head of $70.2 \mathrm{ft}$. An initial surge of positive $0.8 \mathrm{ft}$ occurred approximately 4 min after the start of lock emptying and a return surge of about $-0.7 \mathrm{ft}$ occurred approximately $10 \mathrm{~min}$ after start of emptying when the emptying cycle was completed. The largest surge occurred near the lock at sta 1 and decreased in magnitude as the stations approached the river channel. As the riverflow increased, the magnitude of the surges in water-surface elevations decreased due to a decrease in head and increase in depth of water in the lock canal. Emptying the lock created maximum velocities at sta 1 that varied from +1.4 fps to a -0.3 fps with the 70,400-cfs riverflow and a head of $70.2 \mathrm{ft}$ (Plate 105). The maximum positive velocity occurred about 8 min after start of lock filling and the negative velocity occurred about 10 min later. As the riverflow increased, the magnitude of the surges in the velocity decreased due to a decrease in head and increase in water depth in the canal (Plate 106). Measurements made with barges at the mooring facility are shown in Plates $107-114$. These data indicate that with barges moored at the facility, the surges in watersurface elevation were baffled somewhat, but the surge in the velocity of the current was generally the same as those measured without barges at the facility. With barges at the facility, a maximum surge in water-surface elevation of approximately $1.1 \mathrm{ft}$ occurred with the maximum head (70.2 ft). An initial surge of $+0.7 \mathrm{ft}$ occurred approximately $4 \mathrm{~min}$ after the start of lock emptying and a return surge of about $-0.4 \mathrm{ft}$ occurred approximately 8 min after start of emptying. The largest surge occurred near the lock at sta 1 and decreased in magnitude as the stations approached the river channel. The position of the barges at the facility (located at the upstream end or at the downstream end of the facility) has some influence on the surges in water-surface elevations and velocities of the current.

\section{Experiments with Plan F-1}

Preliminary experiments were conducted with various designs of guard wall to select a design that would enhance the migration of fish through the project without adversely affecting navigation. The Portland District, along with various state and Federal agencies, was involved in the evaluation and selection of the guard wall. Model demonstrations were conducted and dye and confetti were injected in the model to provide information for the agencies to select a guard wall that would provide the best conditions both for the migration of fish and navigation conditions for tows using the project. There were also preliminary experiments with the model tow simulating the design size tow to determine the effects of the currents on tows entering and leaving the new lock. Construction and required strength of the wall were also carefully considered during the evaluations. After careful evaluation, a combination fixed/floating guard wall was selected for full evaluation and documentation. 


\section{Description}

Plan F-1 (Figures 34 and 35) was the same as Plan F except the guard wall of the new lock was modified to an 830-ft-long combination fixed/floating guard wall. The upstream $252 \mathrm{ft}$ of the guard wall was attached to four 52.3-ft-diam cells to provide a rubbing surface for a tow using the wall. A 144-ft-long wall section adjacent to the lock was fixed and spanned from the lock wall to a 52.3-ft-diam cell at sta $18+65$. A floating wall design was used for the 432-ft-long mid section and was anchored between two 52.3-ft-diam cells at sta $18+65$ and 14+10. The fixed part of the wall was $28 \mathrm{ft}$ wide and $13 \mathrm{ft}$ deep with a top elevation of 81.0. The bottom of the fixed walls was at el 68.0. The floating part of the guard wall was $40 \mathrm{ft}$ wide and $26 \mathrm{ft}$ deep and floated with the bottom of the wall $22 \mathrm{ft}$ below the water surface. A skirt with vertical slots was suspended from the fixed part of the guard wall between sta $14+10$ and $12+50$ and from the floating section of the guard wall. The bottom of the skirt attached to the fixed part of the wall was at el 52.0 and the bottom of the skirt attached to the floating part of the wall was $37 \mathrm{ft}$ below the top of the wall or $33 \mathrm{ft}$ below the water surface. The vertical slots were $1 \mathrm{ft}$ wide and extended from the bottom of the wall to the bottom of the skirts. The vertical slots were spaced $6 \mathrm{ft}$ center to center.

\section{Results of experiments with Plan F-1}

Current directions and velocities. Current directions and velocities taken in the immediate vicinity of the new guard wall are shown in Plates $115-117$. The measurements were made with a total riverflow of 335,000 cfs and with the first powerhouse discharging 140,000 cfs. The measurements were made with the upper pool at el $71.5 \mathrm{ft}$ (minimum pool elevation), el $74.0 \mathrm{ft}$ (normal pool elevation), and el $77.0 \mathrm{ft}$ (maximum pool elevation). These data indicate there was no significant change in the direction or velocity of the currents in the vicinity of the guard wall that would adversely affect tows.

Point velocities. Point velocities were measured near the water surface, at mid-depth, and near the channel bottom with the 335,000-cfs total riverflow and a powerhouse discharge of $140,000 \mathrm{cfs}$ to evaluate the effects of the wall on the migration of fish (Plates 118 - 126). The measurements were made with the upper pool at el $71.5 \mathrm{ft}$ (minimum pool elevation), el $74.0 \mathrm{ft}$ (normal pool elevation), and el $77.0 \mathrm{ft}$ (maximum pool elevation). These data provided detailed information to the various agencies for an evaluation of the performance of the guard wall from an environmental standpoint.

Guard wall impact experiments. Experiments were conducted to measure the speed and angle of tows landing on the guard wall both during a normal approach and a loss of power approach. This information was provided to Portland District so the floating guard wall could be designed to withstand normal impacts of tows using the project and for estimating the extent of the damage if a tow were to lose power during its approach to the new lock. These measurements were made using the video tracking system to obtain the angle and 


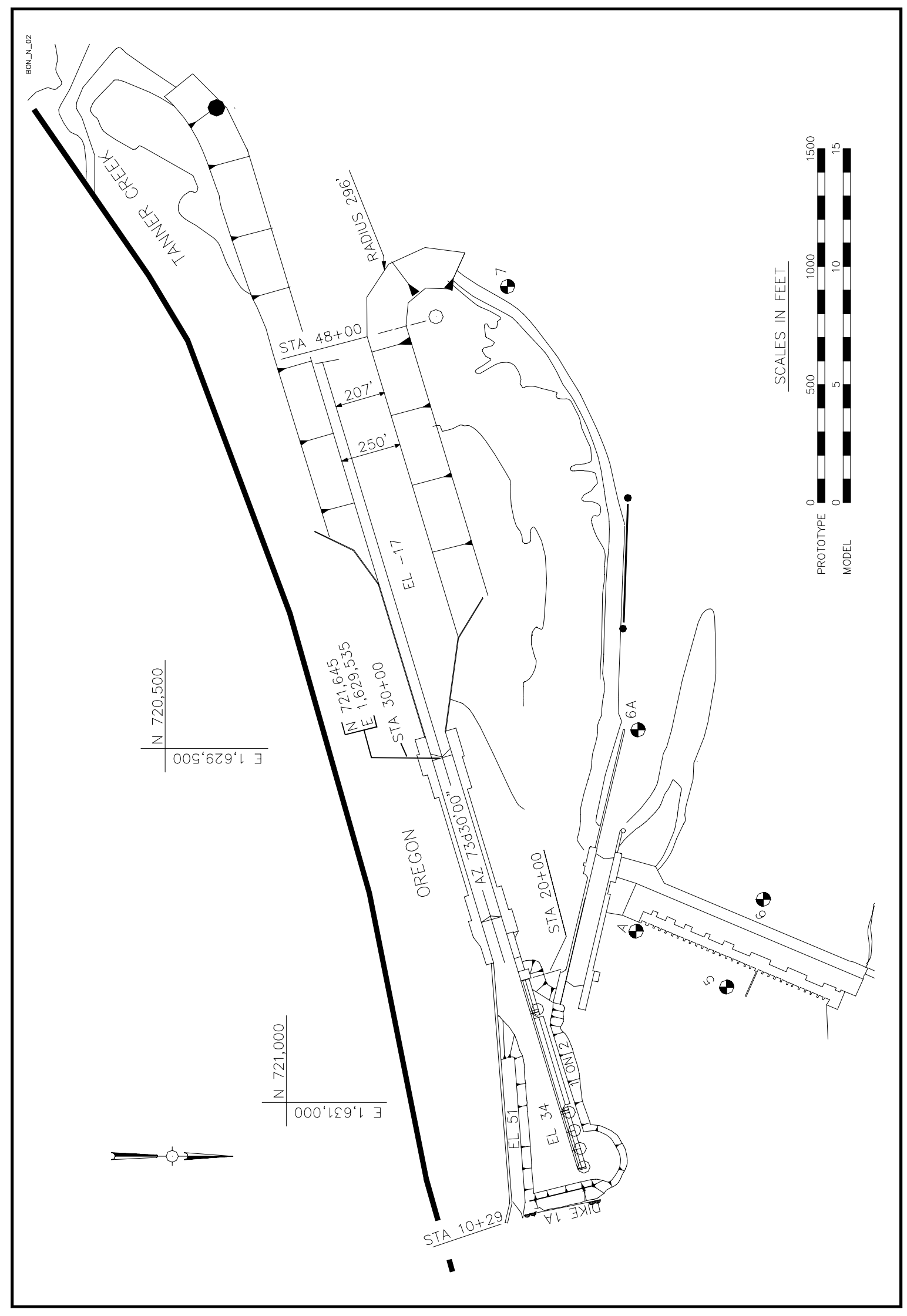

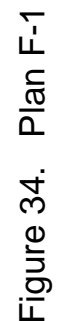




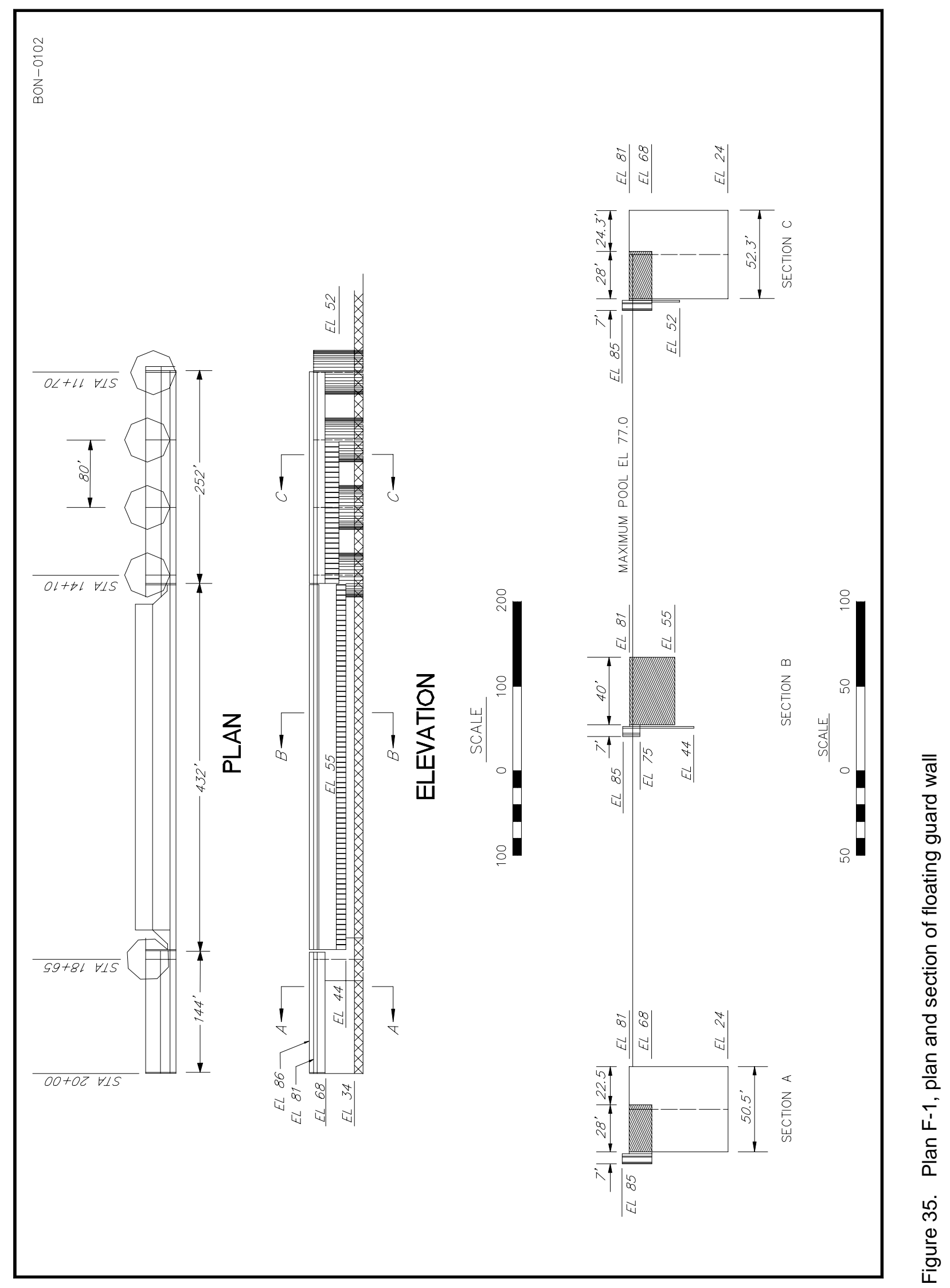


speed of the tow as it landed on the guard wall, either during a normal approach or a loss of power event. Measurements were made during normal approaches (no loss of power) and with a simulated loss of power at five locations in the channel. A loss of power was simulated by cutting all power to the tow and setting the rudders to the center positions when the head of tow was at the selected point. A loss of power was simulated when the head of the tow was at Dike 1-A, Dike 1, Dike 2, Dike 3, and Dike 4. The model simulated a 335,000-cfs total riverflow and 140,000-cfs first powerhouse discharge with the upper pool at el $71.5 \mathrm{ft}$ (minimum pool elevation) and el $74.0 \mathrm{ft}$ (normal pool elevation). Representative runs for each of the experiments are shown in Plates 127 - 132 and the results from all tow runs are tabulated in Tables $7-18$. Data recorded with upper pool el 74.0 (normal pool elevation) indicate the angle of approach for a downbound tow under control (no loss of power) would vary from less than 0.1 to $3.8 \mathrm{deg}$ and its speed would vary from about 1.6 - to $2.3 \mathrm{fps}$ and would land on the wall near the lock in the vicinity of sta $20+00$

(Tables 7 -18). There was a large spread in the angle and velocity of impact that could occur when the tow experienced a loss of power depending on its location when it lost power. Generally the largest angles and speed of impact on the guard wall occurred when the tow lost power at submerged Dike 4, which is the farthest upstream point for loss of power in these experiments. The maximum angle of impact was $22.2 \mathrm{deg}$ and the maximum speed of impact was $6.4 \mathrm{fps}$ (Table 12). This can be attributed to the normal operation of a tow as it approaches the lock. A downbound tow starts reducing speed and aligning with the wall about two tow lengths upstream of the guard wall or about $1,300 \mathrm{ft}$ upstream of the guard wall. Therefore, a tow would still be driving or just starting a flanking maneuver to reduce speed in the vicinity of submerged Dike 4. Impacts recorded with the upper pool at el $71.5 \mathrm{ft}$ (minimum pool elevation) are shown in Tables 13 - 18. These data indicate that the angles and speeds of impact are slightly less than those with the el $74.0 \mathrm{ft}$ pool.

Guard wall construction experiments. Experiments were conducted to demonstrate and evaluate navigation conditions during construction of the new guard wall. During the construction period, tows will continue to use the existing lock to transit the project. The fixed part of the new wall would be constructed in the wet and would be partially in the navigation channel approaching the existing lock. The floating part of the new guard wall will be constructed offsite and floated into place after completion of the new lock. These experiments were designed to provide some guidance for the destruction of the existing guide wall, excavation of the approach to the new lock, construction sequence for the new wall, and when and if some type of assistance should be provided for tows entering and leaving the existing lock. Preliminary experiments indicated tows would not be able to enter and leave the existing lock during construction of the new guard wall if all ten powerhouse units were in operation. Model experiments indicated that the powerhouse should be either completely shut down or, at a minimum, the operation should be reduced to two units. Portland District determined that due to project requirements, the powerhouse would need to operate at least two units or about $28,000 \mathrm{cfs}$ discharge. Therefore, all construction sequence experiments were conducted with powerhouse units 1 and 10 operating, for a total powerhouse discharge of $28,000 \mathrm{cfs}$. Navigation conditions 
were evaluated with a 42 -ft-wide by 320 -ft-long tow (representing a single 42 -ft-wide by 220 -ft-long barge with a 100 -ft-long pusher) and a 42 -ft-wide by 500 -ft-long tow (representing two 42 -ft-wide by 200 -ft-long barges with a 100 -ft-long pusher). Initial experiments indicated construction of the guard wall from the upstream end would provide the best navigation conditions for tows entering and leaving the existing lock for the longest period of time. All experiments were conducted with work barges in place as anticipated by the contractor.

Construction Phase 1 was conducted with guard wall cell No. 1 in place. Work barges were moored along the riverside of the cell for construction of the cell and along the upstream end of the existing guide wall to start destruction of the wall (Plates 133 and 134). These experiments indicate tow size should be limited to one barge and downbound tows could require some assistance moving between the new guard wall cell and the work barges moored along the guide wall. Navigation conditions were satisfactory for upbound tows.

Construction Phase 2 was conducted with guard wall cell Nos. 1 and 2 in place and about $700 \mathrm{ft}$ of the upstream end of the existing guide wall removed. Work barges were moored along the riverside of Cell Nos. 1 and 2 for construction of the cells. During this phase of construction work, barges would be landward of the existing guide wall demolishing the next section of the guide wall. Navigation conditions were satisfactory for a two-barge-tow entering and leaving the existing lock (Plates 135 and 136).

Construction Phase 3 was with guard wall cell Nos. 1, 2, 3, and 4 in place and about $500 \mathrm{ft}$ of the existing guide wall left in place. Work barges were moored riverward of cell Nos. 2 and 3 and landward of the existing guide wall. These experiments indicate tow size should be limited to one barge. Navigation conditions were satisfactory for a one-barge tow entering and leaving the existing lock (Plates 137 and 138).

Construction Phase 4 was the same as Construction Phase 3 except all work barges were landward of the guide wall or along the upstream end of the new guide wall. This restricted the area between the new guard wall cells and the new lock approach. During this phase, tows were required to approach or leave the existing lock by maneuvering riverward of the new guard wall cells (Plates 139 and 140). A downbound tow would be navigating near the river end of the submerged dikes and trying to turn around the new guard wall cells to align with the lock chamber. This would require considerable maneuvering and time or some type of assistance. Navigation conditions for a one-barge tow leaving the existing lock were satisfactory provided the tow exercised due caution. However, an assist towboat should be made available on request.

Construction Phase 5 was the same as Construction Phase 4, except the remainder of the existing guide wall was removed. During this phase of construction work barges may be in the channel between the new guard wall cells and the new lock approach depending on the area being excavated for the new lock approach. Plates 141 and 142 show a scheme where a limited navigation channel is available landward of the new guard wall cells. These experiments 
indicate tows should be limited to one barge during this phase of construction. These data indicate a downbound tow would be required to approach the existing lock riverward of the new guard wall cells (Plate 141). The tow would require some type of assistance or considerable maneuvering and time to enter the lock chamber due to both the maneuvering around the guard wall cells and the absence of a guide wall to aid in aligning with the lock chamber. An upbound tow could either use the channel landward of the guard wall cells or maneuver riverward of the cells (Plate 142). An upbound tow navigating riverward of the guard wall cells would require some type of assistance or considerable time and maneuvering to leave the existing lock. With construction Phase 6, when the channel landward of the guard wall cells was obstructed by work barges, tows would be required to navigate riverward of the cells (Plates 143 and 144).

During this period, upbound and downbound tows would either require some assistance or considerable time and maneuvering to enter and leave the existing lock. 


\section{Discussion of Results and Conclusions}

\section{Limitations of Model Results}

Analysis of this investigation's results is based on a study of : (a) the effects of various plans and modifications on water-surface elevations and current directions and velocities, and (b) the effects of the resulting currents on model towboat and tow behavior. In evaluating the results, it should be taken into consideration that small changes in current directions and velocities are not necessarily changes produced by a modification in the plan since several floats introduced at the same point may follow a different path and move at somewhat different velocities due to pulsating currents and eddies. Current directions and velocities shown in the plates were obtained with floats submerged to the depth of a loaded barge (14-ft prototype) and are more indicative of currents affecting the behavior of tows than those indicated by photographs, which indicate the movement of confetti on the water surface and could be affected by surface tension.

The small scale of the model made it difficult to reproduce accurately the hydraulic characteristics of the prototype structures or to measure water-surface elevation with an accuracy greater than about $\pm 0.1 \mathrm{ft}$ prototype. Also, current directions and velocities were based on steady riverflows and would be somewhat different with varying riverflows. The model was a fixed-bed type and not designed to reproduce overall sediment movement that might occur in the prototype with the various plans. Therefore, changes in channel configuration resulting from scouring and deposition and any resulting changes in current directions and velocities were not evaluated.

\section{Summary of Results and Conclusions}

The following results and conclusions were developed during the investigation:

a. Satisfactory navigation conditions can be established with the new lock positioned landward of the existing lock and rotated relative to the center 
line of the existing lock. However, some modifications to the navigation channel will be required upstream of the lock and the downstream lock canal.

$b$. Adding spur dikes along the left descending bank upstream of Eagle Point will reduce the size of the eddy and improve navigation conditions for tows navigating the reach.

c. Excavation of Eagle Point would further improve navigation conditions for tows turning into the first powerhouse channel.

$d$. Adding submerged dikes in the deep part of the channel approaching the new lock would reduce the outdraft near the upstream end of the new guide wall but increase the velocities somewhat.

e. Excavation of Bradford Island along with adding submerged dikes in the deep part of the channel would improve the alignment of the currents and reduce the velocities. Navigation conditions for tows entering and leaving the new lock would be improved significantly.

f. Plan D-2 provided satisfactory navigation conditions for tows entering and leaving the upstream approach of the new lock.

g. Fill could be placed between the submerged dikes to el 20 without adversely affecting navigation conditions for tows entering and leaving the new lock (Plan E).

$h$. The spur dikes along the left bank upstream of Eagle Point could be replaced with a spoil area without adversely affecting navigation conditions.

i. Plan F provided satisfactory navigation conditions for tows entering and leaving the upstream approach of the new lock with an 810-ft-long floating guard wall. Navigation conditions were satisfactory for tows entering and leaving the downstream lock approach.

j. The fixed/floating guard wall of Plan F-1 provided satisfactory navigation conditions for tows entering and leaving the upper lock approach.

$k$. Navigation can be maintained during construction of the new fixed/ floating guard wall of Plan F-1 and excavation of the approach to the new lock. However, the powerhouse discharge should be limited to $28,000 \mathrm{cfs}$ and the size of the tows should be limited to one or two barges depending on the construction phase. 


\begin{tabular}{|c|c|c|c|c|c|c|}
\hline \multicolumn{7}{|c|}{$\begin{array}{l}\text { Table } 1 \\
\text { Existing Conditions }\end{array}$} \\
\hline \multicolumn{7}{|c|}{ Water-Surface Elevations / Navigation Channel } \\
\hline \multirow[b]{2}{*}{ Gauge No. } & \multicolumn{6}{|c|}{ Discharge in 1,000 Cfs (ft NGVD) } \\
\hline & 70.4 & 118.4 & 200.4 & 335 & 485 & 660 \\
\hline 1 & 74.0 & 74.0 & 74.0 & 74.0 & 74.0 & 74.0 \\
\hline 2 & 74.0 & 74.0 & 73.9 & 73.9 & 74.0 & 74.0 \\
\hline 3 & 74.0 & 74.0 & 73.9 & 73.6 & 73.7 & 73.9 \\
\hline 4 & 73.9 & 74.0 & 73.8 & 73.6 & 73.7 & 74.1 \\
\hline 5 & 73.9 & 74.0 & 73.8 & 73.7 & 73.7 & 74.2 \\
\hline \multicolumn{7}{|c|}{ First Powerhouse } \\
\hline 6 & 7.6 & 11.8 & 17.5 & 25.5 & 32.9 & 38.8 \\
\hline $7^{1}$ & 7.8 & 12.0 & 17.5 & 24.9 & 32.1 & 38.2 \\
\hline 8 & 7.8 & 12.0 & 17.5 & 24.8 & 31.9 & 37.7 \\
\hline 9 & 7.7 & 11.8 & 17.2 & 24.4 & 31.3 & 36.8 \\
\hline 10 & 7.4 & 11.4 & 16.6 & 23.7 & 30.7 & 36.3 \\
\hline \multicolumn{7}{|c|}{ Water-Surface Elevations / Main Channel } \\
\hline 2 & 74.0 & 74.0 & 73.9 & 73.9 & 74.0 & 74.0 \\
\hline$B 5^{1}$ & 74.0 & 74.0 & 74.0 & 74.0 & 74.0 & 74.0 \\
\hline \multicolumn{7}{|c|}{ Axis of Spillway } \\
\hline B6 & 7.9 & 12.2 & 18.0 & 25.7 & 31.9 & 35.6 \\
\hline B7 & 7.8 & 12.1 & 17.9 & 25.6 & 33.1 & 39.1 \\
\hline 8 & 7.8 & 12.0 & 17.5 & 24.8 & 31.9 & 37.7 \\
\hline $\begin{array}{l}\text { Slope 1-5 } \\
\text { (ft/1.2 mi) }\end{array}$ & $<0.1$ & $<0.1$ & $<0.1$ & 0.1 & 0.1 & $<0.1$ \\
\hline $\begin{array}{l}\text { Slope 6-10 } \\
\text { (ft/2.1 mi) }\end{array}$ & 0.2 & 0.3 & 0.4 & 0.6 & 0.7 & 1.0 \\
\hline
\end{tabular}




\begin{tabular}{|c|c|c|c|c|c|c|}
\hline \multicolumn{7}{|c|}{$\begin{array}{l}\text { Table } 2 \\
\text { Original Design }\end{array}$} \\
\hline \multicolumn{7}{|c|}{ Water-Surface Elevations / Navigation Channel } \\
\hline \multirow[b]{2}{*}{ Gauge No. } & \multicolumn{6}{|c|}{ Discharge in 1,000 cfs (ft NGVD) } \\
\hline & 70.4 & 118.4 & 200.4 & 335 & 485 & 660 \\
\hline 1 & 74.0 & 74.0 & 74.0 & 74.0 & 74.0 & 74.0 \\
\hline 2 & 74.0 & 74.0 & 73.9 & 73.8 & 74.0 & 74.0 \\
\hline 3 & 74.0 & 74.0 & 73.9 & 73.8 & 73.7 & 73.9 \\
\hline 4 & 73.9 & 74.0 & 73.8 & 73.8 & 73.7 & 74.1 \\
\hline 5 & 73.9 & 74.0 & 73.8 & 73.9 & 73.7 & 74.2 \\
\hline \multicolumn{7}{|c|}{ First Powerhouse } \\
\hline 6 & 7.6 & 11.6 & 17.5 & 25.6 & 32.9 & 38.7 \\
\hline 7 & 7.8 & 11.8 & 17.4 & 24.9 & 32.1 & 38.1 \\
\hline 8 & 7.8 & 11.8 & 17.4 & 24.9 & 31.9 & 37.8 \\
\hline 9 & 7.7 & 11.7 & 17.2 & 24.5 & 31.3 & 37.0 \\
\hline $10^{1}$ & 7.4 & 11.3 & 16.6 & 23.7 & 30.7 & 36.3 \\
\hline \multicolumn{7}{|c|}{ Water-Surface Elevations / Main Channel } \\
\hline 2 & 74.0 & 73.9 & 73.9 & 74.0 & 74.0 & 74.0 \\
\hline $\mathrm{B}^{1}$ & 74.0 & 74.0 & 74.0 & 74.0 & 74.0 & 74.0 \\
\hline \multicolumn{7}{|c|}{ Axis of Spillway } \\
\hline B6 & 7.8 & 12.0 & 17.8 & 25.7 & 31.9 & 35.7 \\
\hline B7 & 7.8 & 12.0 & 17.8 & 25.7 & 33.1 & 39.1 \\
\hline 8 & 7.7 & 11.8 & 17.4 & 24.9 & 31.9 & 37.8 \\
\hline $\begin{array}{l}\text { Slope 1-5 } \\
\text { (ft/1.2 mi) }\end{array}$ & $<0.1$ & $<0.1$ & $<0.1$ & $<0.1$ & 0.1 & $<0.1$ \\
\hline $\begin{array}{l}\text { Slope 6-10 } \\
\text { (ft/2.1 mi) }\end{array}$ & 0.1 & 0.1 & 0.4 & 0.9 & 0.7 & 1.1 \\
\hline
\end{tabular}




\begin{tabular}{|c|c|c|c|c|}
\hline \multicolumn{5}{|c|}{$\begin{array}{l}\text { Table } 3 \\
\text { Plans A Through A-3, Discharge } 335,000 \text { cfs }\end{array}$} \\
\hline \multicolumn{5}{|c|}{ Water-Surface Elevations / Navigation Channel } \\
\hline \multirow[b]{2}{*}{ Gauge No. } & \multicolumn{4}{|c|}{ Plans } \\
\hline & A & $A-1$ & A-2 & A-3 \\
\hline 1 & 74.0 & 74.0 & 74.0 & 74.0 \\
\hline 2 & 73.7 & 73.7 & 73.7 & 73.6 \\
\hline 3 & 73.5 & 73.5 & 73.5 & 73.5 \\
\hline 4 & 73.3 & 73.1 & 73.1 & 73.0 \\
\hline 5 & 73.4 & 73.2 & 73.1 & 73.0 \\
\hline \multicolumn{5}{|c|}{ First Powerhouse /Dam } \\
\hline 6 & 25.6 & 25.5 & 25.5 & 25.4 \\
\hline 7 & 24.8 & 24.9 & 24.9 & 24.9 \\
\hline 8 & 24.8 & 24.8 & 24.9 & 24.7 \\
\hline 9 & 24.4 & 24.4 & 24.5 & 24.3 \\
\hline $10^{1}$ & 23.7 & 23.7 & 23.7 & 23.7 \\
\hline $\begin{array}{l}\text { Slope 1-5 } \\
\text { (ft/1.2 mi) }\end{array}$ & 0.5 & 0.7 & 0.7 & 0.8 \\
\hline $\begin{array}{l}\text { Slope 6-10 } \\
\text { (ft/2.1 mi) }\end{array}$ & 0.9 & 0.9 & 0.9 & 0.8 \\
\hline
\end{tabular}




\begin{tabular}{|c|c|c|c|}
\hline \multicolumn{4}{|c|}{$\begin{array}{l}\text { Table } 4 \\
\text { Plans B Through B-2, Discharge } 335,000 \text { cfs }\end{array}$} \\
\hline \multicolumn{4}{|c|}{ Water-Surface Elevations / Navigation Channel } \\
\hline \multirow[b]{2}{*}{ Gauge No. } & \multicolumn{3}{|c|}{ Plans } \\
\hline & B & B-1 & B-2 \\
\hline 1 & 74.0 & 74.0 & 74.0 \\
\hline 2 & 73.8 & 73.8 & 73.7 \\
\hline 3 & 73.6 & 73.5 & 73.6 \\
\hline 4 & 73.2 & 73.2 & 73.1 \\
\hline 5 & 73.3 & 73.2 & 73.1 \\
\hline \multicolumn{4}{|c|}{ First Powerhouse /Dam } \\
\hline 6 & 25.5 & 25.4 & 25.5 \\
\hline 7 & 24.9 & 24.8 & 24.8 \\
\hline 8 & 24.8 & 24.8 & 24.8 \\
\hline 9 & 24.4 & 24.4 & 24.4 \\
\hline $10^{1}$ & 23.7 & 23.7 & 23.7 \\
\hline $\begin{array}{l}\text { Slope 1-5 } \\
\text { (ft/1.2 mi) }\end{array}$ & 0.6 & 0.7 & 0.7 \\
\hline $\begin{array}{l}\text { Slope 6-10 } \\
\text { (ft/2.1 mi) }\end{array}$ & 0.9 & 0.8 & 0.9 \\
\hline
\end{tabular}




\begin{tabular}{|c|c|c|c|}
\hline \multicolumn{4}{|c|}{$\begin{array}{l}\text { Table } 5 \\
\text { Plans C Through C-2, Discharge } 335,000 \text { cfs }\end{array}$} \\
\hline \multicolumn{4}{|c|}{ Water-Surface Elevations / Navigation Channel } \\
\hline \multirow[b]{2}{*}{ Gauge No. } & \multicolumn{3}{|c|}{ Plans } \\
\hline & C & C-1 & C-2 \\
\hline 1 & 74.0 & 74.0 & 74.0 \\
\hline 2 & 73.8 & 73.9 & 73.8 \\
\hline 3 & 73.6 & 73.7 & 73.7 \\
\hline 4 & 73.3 & 73.4 & 73.4 \\
\hline 5 & 73.4 & 73.4 & 73.3 \\
\hline \multicolumn{4}{|c|}{ First Powerhouse /Dam } \\
\hline 6 & 25.5 & 25.5 & 25.5 \\
\hline 7 & 25.0 & 24.9 & 24.9 \\
\hline 8 & 24.8 & 24.8 & 24.8 \\
\hline 9 & 24.4 & 24.4 & 24.4 \\
\hline $10^{1}$ & 23.7 & 23.7 & 23.7 \\
\hline $\begin{array}{l}\text { Slope 1-5 } \\
\text { (ft/1.2 mi) }\end{array}$ & 0.5 & 0.5 & 0.6 \\
\hline $\begin{array}{l}\text { Slope 6-10 } \\
\text { (ft/2.1 mi) }\end{array}$ & 0.9 & 0.9 & 0.9 \\
\hline
\end{tabular}




\begin{tabular}{|c|c|c|c|c|c|c|}
\hline \multicolumn{7}{|l|}{$\begin{array}{l}\text { Table } 6 \\
\text { Plan F }\end{array}$} \\
\hline \multicolumn{7}{|c|}{ Water-Surface Elevations / Navigation Channel } \\
\hline \multirow[b]{2}{*}{ Gauge No. } & \multicolumn{6}{|c|}{ Discharge in $1,000 \mathrm{cfs}$ (ft NGVD) } \\
\hline & 70.4 & 118.4 & 200.4 & 335 & 485 & 660 \\
\hline 1 & 74.0 & 74.0 & 74.0 & 74.0 & 74.0 & 74.0 \\
\hline 2 & 74.0 & 74.0 & 73.9 & 73.8 & 74.0 & 74.0 \\
\hline 3 & 74.0 & 74.0 & 73.9 & 73.8 & 73.7 & 73.9 \\
\hline 4 & 73.9 & 74.0 & 73.8 & 73.8 & 73.7 & 74.1 \\
\hline 5 & 73.9 & 74.0 & 73.8 & 73.9 & 73.7 & 74.2 \\
\hline \multicolumn{7}{|c|}{ First Powerhouse } \\
\hline 6 & 7.6 & 11.6 & 17.5 & 25.6 & 32.9 & 38.7 \\
\hline 7 & 7.8 & 11.8 & 17.4 & 24.9 & 32.1 & 38.1 \\
\hline 8 & 7.8 & 11.8 & 17.4 & 24.9 & 31.9 & 37.8 \\
\hline 9 & 7.7 & 11.7 & 17.2 & 24.5 & 31.3 & 37.0 \\
\hline $10^{1}$ & 7.4 & 11.3 & 16.6 & 23.7 & 30.7 & 36.3 \\
\hline \multicolumn{7}{|c|}{ Water-Surface Elevations / Main Channel } \\
\hline 2 & 74.0 & 73.9 & 73.9 & 74.0 & 74.0 & 74.0 \\
\hline$B 5^{1}$ & 74.0 & 74.0 & 74.0 & 74.0 & 74.0 & 74.0 \\
\hline \multicolumn{7}{|c|}{ Axis of Spillway } \\
\hline B6 & 7.8 & 12.0 & 17.8 & 25.7 & 31.9 & 35.7 \\
\hline B7 & 7.8 & 12.0 & 17.8 & 25.7 & 33.1 & 39.1 \\
\hline 8 & 7.7 & 11.8 & 17.4 & 24.9 & 31.9 & 37.8 \\
\hline $\begin{array}{l}\text { Slope 1-5 } \\
\text { (ft/1.2 mi) }\end{array}$ & $<0.1$ & $<0.1$ & $<0.1$ & $<0.1$ & 0.1 & $<0.1$ \\
\hline $\begin{array}{l}\text { Slope 6-10 } \\
\text { (ft/2.1 mi) }\end{array}$ & 0.1 & 0.1 & 0.4 & 0.9 & 0.7 & 1.1 \\
\hline
\end{tabular}




\begin{tabular}{|c|c|c|c|c|c|c|c|}
\hline \multicolumn{8}{|c|}{$\begin{array}{l}\text { Table } 7 \\
\text { Plan F-1, Guard Wall Impact Experiments }\end{array}$} \\
\hline \multicolumn{8}{|c|}{ Total Riverflow $=335,000$ cfs, First Powerhouse $Q=140,000$ cfs, Upper Pool el 74.0} \\
\hline \multirow[b]{2}{*}{$\begin{array}{l}\text { Run } \\
\text { No. }\end{array}$} & \multicolumn{7}{|c|}{ No Loss of Power } \\
\hline & Dike 4 & Dike 3 & Dike 2 & Dike 1 & Dike 1-A & Guidewall & $\begin{array}{l}\text { Impact @ } \\
\text { Station }\end{array}$ \\
\hline $1^{1}$ & $6.3 /-16.0$ & $5.2 /-10.3$ & $3.8 /-4.6$ & $3.4 / 2.9$ & $4.6 / 3.2$ & $1.8 / 1.9$ & $20+29$ \\
\hline 2 & $7.1 /-16.5$ & $7.1 /-7.9$ & $6.2 /-1.5$ & $5.3 / 3.6$ & $5.0 / 5.5$ & $2.2 / 1.2$ & $20+27$ \\
\hline 3 & $7.3 /-12.2$ & $7.3 /-5.36$ & $6.2 / 0.0$ & $4.6 / 5.5$ & $4.2 / 6.8$ & 2.3/3.8 & $16+56$ \\
\hline 4 & $6.9 /-10.1$ & $7.1 /-5.2$ & $5.8 /-7.0$ & $4.3 / 1.8$ & $3.6 / 2.3$ & $1.6 / 2.0$ & $20+16$ \\
\hline 5 & $6.0 /-16.1$ & $5.2 /-10.5$ & $3.7 /-6.5$ & $3.8 / 0.3$ & $4.9 / 1.0$ & $2.1 / 1.7$ & $20+08$ \\
\hline 6 & $6.5 /-6.1$ & $6.9 /-2.6$ & $5.7 / 0.0$ & $4.3 / 2.3$ & $3.8 / 3.6$ & $1.4 / 0.8$ & $20+02$ \\
\hline 7 & $6.4 /-13.0$ & $5.6 /-7.7$ & $3.8 /-5.2$ & $3.1 /-1.0$ & $4.1 / 0.2$ & $2.0 / 1.8$ & $20+17$ \\
\hline 8 & $6.8 /-14.9$ & $7.1 /-11.8$ & $6.9 /-8.6$ & $6.1 /-6.2$ & $6.7 /-4.6$ & $1.9 / 1.8$ & $19+97$ \\
\hline 9 & $7.7 /-26.2$ & $7.9 /-28.9$ & $7.8 /-27.5$ & $7.1 /-22.9$ & $6.9 /-21.1$ & $1.9 / 0.0$ & $20+03$ \\
\hline $10^{1}$ & $6.4 /-5.1$ & $6.6 / 0.3$ & $5.9 / 2.4$ & $4.9 / 5.4$ & $4.8 / 6.1$ & $1.6 / 1.0$ & $20+21$ \\
\hline
\end{tabular}

\section{Table 8 \\ Plan F-1, Guard Wall Impact Experiments}

\begin{tabular}{|c|c|c|c|c|c|c|c|}
\hline \multicolumn{8}{|c|}{ Total Riverflow $=335,000$ cfs, First Powerhouse $Q=140,000$ cfs, Upper Pool el 74.0} \\
\hline \multirow[b]{2}{*}{$\begin{array}{l}\text { Run } \\
\text { No. }\end{array}$} & \multicolumn{7}{|c|}{ Loss of Power at Dike 1-A } \\
\hline & Dike 4 & Dike 3 & Dike 2 & Dike 1 & Dike 1-A & Guidewall & $\begin{array}{l}\text { Impact @ } \\
\text { Station }\end{array}$ \\
\hline $1^{1}$ & $5.7 /-15.1$ & $5.4 /-7.0$ & $4.2 / 0.0$ & $4.2 / 6.7$ & $4.9 / 6.1$ & $2.1 /-2.7$ & NO HIT \\
\hline 2 & $5.7 /-14.9$ & $5.4 /-8.2$ & $4.7 /-2.1$ & $4.3 /-1.1$ & $4.5 / 1.3$ & $3.8 / 10.5$ & $17+00$ \\
\hline 3 & $7.6 /-20.1$ & $8.0 /-12.2$ & $7.2 /-6.7$ & $6.1 /-2.8$ & $5.8 /-1.1$ & $4.6 / 7.7$ & $15+89$ \\
\hline 4 & $8.3 /-30.7$ & 8.3/-21.8 & $6.8 /-16.0$ & $4.9 /-11.4$ & $3.7 /-6.5$ & $2.0 /-5.6$ & NO HIT \\
\hline 5 & $5.7 /-14.9$ & $5.4 /-8.2$ & $4.7 /-2.1$ & $4.3 /-1.1$ & $4.5 / 1.3$ & $3.8 / 10.5$ & $16+98$ \\
\hline 6 & $7.1 /-18.4$ & $6.8 /-12.2$ & $6.0 /-8.1$ & $5.3 /-3.2$ & $4.7 /-0.2$ & $1.6 / 0.2$ & $20+23$ \\
\hline 7 & $5.1 /-17.7$ & $4.0 /-12.8$ & $3.6 /-8.5$ & $4.5 /-4.9$ & $4.5 /-4.2$ & $0.9 /-4.6$ & $19+00$ \\
\hline 8 & $7.0 /-10.6$ & $7.5 /-6.3$ & $5.8 /-2.0$ & $4.3 / 2.1$ & $4.3 / 1.7$ & $1.9 /-3.1$ & $20+12$ \\
\hline 9 & $7.8 /-18.7$ & $7.7 /-12.8$ & $6.0 /-9.1$ & $5.0 /-7.4$ & $4.6 /-4.4$ & $1.8 /-07$ & $20+10$ \\
\hline $10^{1}$ & $6.7 /-19.0$ & $7.0 /-9.2$ & $5.5 /-2.3$ & $4.6 / 3.3$ & $4.5 / 4.1$ & $0.6 /-4.3$ & $18+83$ \\
\hline
\end{tabular}

17.2/9.0 represents $7.2 \mathrm{fps}$ velocity and 9.0 deg rotation of tow relative to the center line of lock when head of tow is at selected point. Positive angle is rotation toward the guard wall. 


\begin{tabular}{|c|c|c|c|c|c|c|c|}
\hline \multicolumn{8}{|c|}{$\begin{array}{l}\text { Table } 9 \\
\text { Plan F-1, Guard Wall Impact Experiments }\end{array}$} \\
\hline \multicolumn{8}{|c|}{ Total Riverflow $=335,000$ cfs, First Powerhouse $Q=140,000$ cfs, Upper Pool el 74.0} \\
\hline \multirow[b]{2}{*}{$\begin{array}{l}\text { Run } \\
\text { No. }\end{array}$} & \multicolumn{7}{|c|}{ Loss of Power at Dike 1} \\
\hline & Dike 4 & Dike 3 & Dike 2 & Dike 1 & Dike 1-A & Guidewall & $\begin{array}{l}\text { Impact @ } \\
\text { Station }\end{array}$ \\
\hline $1^{1}$ & $6.5 /-10.6$ & $6.0 /-6.5$ & $4.9 /-1.4$ & $4.3 /$ & $4.7 / 2.6$ & $4.0 / 0.0$ & $20+34$ \\
\hline 2 & $7.0 /-9.8$ & $7.0 /-7.4$ & $6.1 /-4.4$ & $4.8 /$ & $5.2 / 0.4$ & $2.4 / 1.6$ & $20+26$ \\
\hline 3 & $6.8 /-14.4$ & $7.0 /-9.3$ & $5.6 /-4.2$ & $4.3 /$ & $4.8 /-0.9$ & $1.3 /-3.5$ & $19+11$ \\
\hline 4 & $6.7 /-10.3$ & $6.1 /-6.7$ & $4.5 /-2.1$ & $4.4 /$ & $4.8 / 3.4$ & $4.2 / 14.8$ & $15+70$ \\
\hline 5 & $7.5 /-13.2$ & $7.0 /-7.6$ & $5.5 /-2.2$ & $4.8 /$ & $4.9 / 5.5$ & $2.7 / 2.7$ & $20+28$ \\
\hline 6 & $6.8 /-16.3$ & $6.4 /-10.9$ & $4.8 /-7.3$ & $4.6 /$ & $4.8 /-1.6$ & $3.3 / 9.5$ & $20+21$ \\
\hline 7 & $6.7 /-9.9$ & $6.2 /-5.9$ & $5.1 /-3.7$ & $4.8 /$ & $5.5 / 3.4$ & $5.1 / 11.2$ & $14+96$ \\
\hline 8 & $8.1 /-31.2$ & $7.6 /-25.1$ & $6.0 /-22.2$ & $4.0 /$ & $4.1 /-5.2$ & $3.8 / 6.1$ & $16+81$ \\
\hline 9 & $6.8 /-16.3$ & $6.4 /-10.9$ & $4.8 /-7.3$ & $4.6 /$ & $4.8 /-1.6$ & $3.3 / 9.5$ & $20+21$ \\
\hline $10^{1}$ & $6.4 /-18.3$ & $6.0 /-12.5$ & $4.8 /-8.1$ & $4.5 /$ & $4.9 / 2.3$ & $4.2 / 3.1$ & $16+77$ \\
\hline
\end{tabular}

\section{Table 10 \\ Plan F-1, Guard Wall Impact Experiments}

Total Riverflow $=335,000$ cfs, First Powerhouse $Q=140,000$ cfs, Upper Pool el 74.0.

\begin{tabular}{|c|c|c|c|c|c|c|c|}
\hline \multirow[b]{2}{*}{$\begin{array}{l}\text { Run } \\
\text { No. }\end{array}$} & \multicolumn{7}{|c|}{ Loss of Power at Dike 2} \\
\hline & Dike 4 & Dike 3 & Dike 2 & Dike 1 & Dike 1-A & Guidewall & $\begin{array}{l}\text { Impact @ } \\
\text { Station }\end{array}$ \\
\hline $1^{1}$ & $6.6 /-16.3$ & $6.2 /-11.5$ & $5.0 /-4.8$ & $4.7 /-0.3$ & $5.2 / 3.2$ & $4.1 / 12.7$ & $17+24$ \\
\hline 2 & $7.3 /-15.3$ & $6.1 /-10.0$ & $4.7 /-7.0$ & $4.7 /-5.9$ & $5.2 /-4.8$ & $0.9 /-1.1$ & $19+81$ \\
\hline 3 & $6.9 /-10.7$ & $5.9 /-6.5$ & $5.0 /-3.4$ & $4.7 /-0.3$ & $5.2 / 3.2$ & $4.8 / 12.3$ & $14+53$ \\
\hline 4 & $6.7 /-11.4$ & $6.3 /-8.0$ & $5.7 /-5.3$ & $5.3 /-2.1$ & $5.5 / 1.8$ & $2.5 / 5.8$ & $20+16$ \\
\hline 5 & $7.8 /-16.9$ & $7.4 /-11.7$ & $6.4 /-7.3$ & $5.7 /-3.3$ & $6.0 / 0.7$ & $4.5 / 10.5$ & $17+90$ \\
\hline 6 & $7.2 /-12.0$ & 7.3/-7.2 & $6.6 /-2.8$ & $6.1 / 0.5$ & $6.4 / 2.9$ & $3.1 / 9.1$ & $20+25$ \\
\hline 7 & $6.4 /-14.3$ & $5.9 /-9.3$ & $5.2 /-5.9$ & $5.0 /-2.3$ & $5.3 / 0.8$ & $2.4 / 4.3$ & $20+02$ \\
\hline 8 & $7.0 /-14.5$ & $6.2 /-8.9$ & $5.1 /-3.4$ & $4.6 / 1.4$ & $5.2 / 4.6$ & $4.4 / 14.6$ & $16+30$ \\
\hline 9 & $7.2 /-13.5$ & $5.5 /-8.7$ & $4.3 /-1.5$ & $4.2 / 5.4$ & $4.5 / 7.4$ & $4.3 / 15.5$ & $16+05$ \\
\hline $10^{1}$ & $6.6 /-13.0$ & $5.8 /-5.8$ & $5.1 / 0.3$ & $4.7 / 6.3$ & $5.2 / 7.8$ & $4.5 / 16.3$ & $16+46$ \\
\hline
\end{tabular}

17.2/9.0 represents $7.2 \mathrm{fps}$ velocity and 9.0 deg rotation of tow relative to the center line of lock when head of tow is at selected point. Positive angle is rotation toward the guard wall. 


\begin{tabular}{|c|c|c|c|c|c|c|c|}
\hline \multicolumn{8}{|c|}{$\begin{array}{l}\text { Table } 11 \\
\text { Plan F-1, Guard Wall Impact Experiments }\end{array}$} \\
\hline \multicolumn{8}{|c|}{ Total Riverflow $=335,000$ cfs, First Powerhouse $Q=140,000$ cfs, Upper Pool el 74.0. } \\
\hline \multirow[b]{2}{*}{$\begin{array}{l}\text { Run } \\
\text { No. }\end{array}$} & \multicolumn{7}{|c|}{ Loss of Power at Dike 3} \\
\hline & Dike 4 & Dike 3 & Dike 2 & Dike 1 & Dike 1-A & Guidewall & $\begin{array}{l}\text { Impact @ } \\
\text { Station }\end{array}$ \\
\hline $1^{1}$ & $7.2 /-15.2$ & $6.4 /-9.1$ & $6.1 /-3.4$ & $5.4 / 2.8$ & $5.7 / 6.6$ & $5.3 / 17.9$ & $14+86$ \\
\hline 2 & $6.5 /-15.3$ & $5.9 /-6.9$ & $5.7 / 1.0$ & $5.2 / 7.0$ & $5.6 / 10.2$ & $4.9 / 7.4$ & $15+71$ \\
\hline 3 & $6.9 /-15.9$ & $6.6 /-9.8$ & $6.0 /-4.7$ & $5.7 / 5.0$ & $5.9 / 4.2$ & $4.8 / 16.4$ & $16+67$ \\
\hline 4 & $5.0 /-13.8$ & $4.4 /-6.9$ & $4.3 /-4.3$ & $4.2 / 0.3$ & $4.6 / 2.3$ & $1.0 / 1.2$ & $19+72$ \\
\hline 5 & $6.5 /-11.1$ & $6.1 /-5.5$ & $5.6 /-0.4$ & $5.3 / 6.2$ & $5.6 / 8.8$ & $5.0 / 18.6$ & $15+80$ \\
\hline 6 & $5.3 /-8.6$ & $5.2 /-3.2$ & $4.9 / 2.7$ & $4.6 / 8.6$ & $4.9 / 11.2$ & $4.9 / 18.8$ & $14+90$ \\
\hline 7 & $6.3 /-15.2$ & $6.0 /-11.7$ & $5.8 /-7.4$ & $5.3 /-4.2$ & $5.6 /-1.1$ & $2.3 / 4.4$ & $19+88$ \\
\hline 8 & $5.7 /-8.0$ & $5.5 /-2.6$ & $5.2 / 1.0$ & $5.0 / 5.0$ & $5.3 / 7.4$ & $2.9 / 4.8$ & $20+08$ \\
\hline 9 & $6.3 /-10.3$ & $6.1 /-6.1$ & $5.8 /-2.2$ & $5.2 / 1.2$ & $5.5 / 4.2$ & $5.0 / 6.1$ & $15+75$ \\
\hline $10^{1}$ & & & & & & & \\
\hline
\end{tabular}

\section{Table 12 \\ Plan F-1, Guard Wall Impact Experiments}

\begin{tabular}{|c|c|c|c|c|c|c|c|}
\hline \multirow[b]{2}{*}{$\begin{array}{l}\text { Run } \\
\text { No. }\end{array}$} & \multicolumn{7}{|c|}{ Loss of Power at Dike 4} \\
\hline & Dike 4 & Dike 3 & Dike 2 & Dike 1 & Dike 1-A & Guidewall & $\begin{array}{l}\text { Impact @ } \\
\text { Station }\end{array}$ \\
\hline $1^{1}$ & $7.2 /-8.4$ & $7.0 /-1.7$ & $6.5 / 6.4$ & $6.0 / 9.1$ & $6.2 / 8.6$ & $4.4 / 10.3$ & $18+25$ \\
\hline 2 & 7.3/-9.3 & $7.1 /-3.5$ & $6.7 / 3.5$ & $5.9 / 10.4$ & $6.0 / 15.5$ & $5.5 / 22.2$ & $14+15$ \\
\hline 3 & $6.2 /-10.2$ & $6.3 /-4.2$ & $6.0 / 1.8$ & $5.5 / 6.5$ & $5.7 / 10.7$ & $5.3 / 21.9$ & $14+43$ \\
\hline 4 & $7.0 /-9.1$ & $6.7 /-0.5$ & $6.3 / 7.3$ & $5.6 / 13.8$ & $5.8 / 15.7$ & $5.3 / 21.6$ & $14+69$ \\
\hline 5 & $7.6 /-27.1$ & 7.4/-23.6 & 6.8/-22.1 & \multicolumn{4}{|c|}{ HIT BANK BETWEEN DIKES 1 AND 2} \\
\hline 6 & $7.1 /-11.9$ & $7.1 /-0.9$ & $6.4 / 6.8$ & $5.6 / 13.7$ & $6.0 / 15.4$ & $5.4 / 20.5$ & $14+67$ \\
\hline 7 & $7.5 /-8.0$ & $7.7 /-2.2$ & 6.7/3.3 & $6.2 / 9.4$ & $6.4 / 13.0$ & $6.4 / 16.3$ & $12+03$ \\
\hline 8 & $6.8 /-26.6$ & 6.6/-22.9 & 4.0/-19.3 & $3.8 /-11.9$ & $4.4 /-10.1$ & $3.6 /-12.0$ & $14+67$ \\
\hline 9 & $7.4 /-16.4$ & $7.4 /-10.2$ & $6.7 /-4.2$ & $6.3 /-0.3$ & $6.5 / 2.0$ & $6.0 / 7.4$ & $15+67$ \\
\hline $10^{1}$ & $7.4 /-18.5$ & $7.2 /-11.4$ & $6.5 /-5.3$ & $6.2 / 2.4$ & $6.0 / 5.2$ & $2.5 / 10.3$ & $20+00$ \\
\hline
\end{tabular}

1 7.2/9.0 represents $7.2 \mathrm{fps}$ velocity and 9.0 deg rotation of tow relative to the center line of lock when head flow is at selected point. Positive angle is rotation toward the guard wall. 


\begin{tabular}{|c|c|c|c|c|c|c|c|}
\hline \multicolumn{8}{|c|}{$\begin{array}{l}\text { Table } 13 \\
\text { Plan F-1, Guard Wall Impact Experiments }\end{array}$} \\
\hline \multicolumn{8}{|c|}{ Total Riverflow $=335,000$ cfs, First Powerhouse $Q=140,000$ cfs, Upper Pool el 71.5} \\
\hline \multirow[b]{2}{*}{$\begin{array}{l}\text { Run } \\
\text { No. }\end{array}$} & \multicolumn{7}{|c|}{ No Loss of Power } \\
\hline & Dike 4 & Dike 3 & Dike 2 & Dike 1 & Dike 1-A & Guidewall & $\begin{array}{l}\text { Impact @ } \\
\text { Station }\end{array}$ \\
\hline $1^{1}$ & $8.1 /-11.5$ & 8.1/-3.6 & $5.0 / 0.0$ & $4.3 / 2.0$ & $4.8 / 2.2$ & $2.3 / 2.3$ & $20+31$ \\
\hline 2 & $7.8 /-16.2$ & 7.3/-9.5 & $5.7 /-7.5$ & $5.1 /-5.2$ & $5.2 /-4.1$ & $1.4 /-0.4$ & $20+31$ \\
\hline 3 & $7.7 /-15.8$ & $8.5 /-9.6$ & $6.8 /-5.1$ & $5.9 /-3.7$ & $5.7 /-2.3$ & $3.6 / 0.9$ & $15+98$ \\
\hline 4 & $7.9 /-16.3$ & $7.4 /-9.4$ & $6.3 /-4.6$ & $4.9 / 1.3$ & $4.4 / 3.0$ & $1.6 / 1.3$ & $20+13$ \\
\hline 5 & $9.0 /-25.3$ & $9.9 /-19.6$ & 8.3/-12.3 & $7.8 /-5.6$ & $7.6 /-2.9$ & $5.1 / 0.6$ & $20+23$ \\
\hline 6 & $7.9 /-11.9$ & 7.3/-5.7 & $5.5 /-2.5$ & $5.0 /-0.2$ & $5.9 /-0.3$ & $1.3 / 0.8$ & $20+15$ \\
\hline 7 & $8.9 /-14.8$ & $8.8 /-7.7$ & $7.7 /-3.0$ & $7.3 / 2.0$ & $7.2 / 4.7$ & $3.7 / 6.4$ & $16+12$ \\
\hline 8 & 8.6/-23.7 & $9.4 /-14.5$ & $7.2 /-8.5$ & $5.2 /-3.0$ & $3.3 /-1.3$ & $3.1 / 1.3$ & $20+31$ \\
\hline 9 & $7.6 /-13.5$ & $8.2 /-10.3$ & $6.5 /-6.8$ & $5.6 /-4.9$ & $5.5 /-3.6$ & $1.4 /-1.0$ & $20+09$ \\
\hline $10^{1}$ & $7.8 /-11.5$ & $7.0 /-7.6$ & $5.9 /-4.1$ & $4.9 /-1.5$ & $5.0 / 1.4$ & $2.5 / 8.6$ & $16+77$ \\
\hline
\end{tabular}

17.2/9.0 represents $7.2 \mathrm{fps}$ velocity and 9.0 deg rotation of tow relative to the center line of lock when head of tow is at selected point. Positive angle is rotation toward the guard wall.

\section{Table 14 \\ Plan F-1, Guard Wall Impact Experiments}

Total Riverflow $=335,000$ cfs, First Powerhouse $Q=140,000$ cfs, Upper Pool el 71.5

\begin{tabular}{||l|l|l|l|l|l|l|l||}
\hline \multirow{3}{*}{$\begin{array}{l}\text { Run } \\
\text { No. }\end{array}$} & \multicolumn{7}{|c||}{ Loss of Power at Dike 1-A } \\
\cline { 2 - 8 } & Dike 4 & Dike 3 & Dike 2 & Dike 1 & Dike 1-A & Guidewall & $\begin{array}{l}\text { Impact @ } \\
\text { Station }\end{array}$ \\
\hline \hline 11 & $7.4 /-14.2$ & $6.9 /-7.0$ & $5.9 /-1.9$ & $5.0 / 0.6$ & $4.8 / 0.7$ & $1.7 / 0.7$ & $20+31$ \\
\hline 2 & $7.4 /-12.7$ & $7.5 /-6.4$ & $6.5 /-2.5$ & $5.3 /-1.0$ & $4.8 /-0.4$ & $3.8 / 13.4$ & $16+08$ \\
\hline 3 & $7.5 /-18.2$ & $6.9 /-11.5$ & $5.8 /-7.5$ & $4.8 /-5.8$ & $4.6 /-5.0$ & $1.1 / 1.1$ & $20+31$ \\
\hline 4 & $8.0 /-21.6$ & $8.3 /-13.8$ & $7.2 /-8.5$ & $6.4 /-6.4$ & $6.1 /-5.6$ & $1.0 /-4.3$ & $19+41$ \\
\hline 5 & $7.4 /-16.1$ & $6.8 /-10.7$ & $5.9 /-7.0$ & $4.8 /-6.6$ & $4.9 /-6.3$ & & NO HIT \\
\hline 6 & $7.4 /-16.6$ & $7.8 /-13.4$ & $6.8 /-11.7$ & $6.0 /-10.1$ & $5.2 /-7.8$ & $4.1 /-3.5$ & $12+81$ \\
\hline 7 & $8.9 /-17.6$ & $8.7 /-12.4$ & $7.0 /-9.4$ & $6.2 /-6.7$ & $6.2 /-5.7$ & $2.3 / 0.4$ & $16+82$ \\
\hline 8 & $8.3 /-18.3$ & $8.9 /-13.5$ & $7.9 /-9.1$ & $7.3 /-4.8$ & $7.0 / 2.9$ & $4.4 /-1.2$ & $16+80$ \\
\hline 9 & $8.4 /-16.4$ & $8.6 /-11.3$ & $7.0 /-7.2$ & $5.7 /-5.7$ & $5.2 /-4.2$ & $2.9 /-1.8$ & $16+80$ \\
\hline 10 & $5.8 /-15.5$ & $5.4 /-8.6$ & $3.9 /-4.7$ & $4.1 /-0.9$ & $4.4 / 0.3$ & $4.2 / 10.8$ & $13+78$ \\
\hline \hline 7
\end{tabular}

17.2/9.0 represents $7.2 \mathrm{fps}$ velocity and 9.0 deg rotation of tow relative to the center line of lock when head of tow is at selected point. Positive angle is rotation toward the guard wall. 


\begin{tabular}{|c|c|c|c|c|c|c|c|}
\hline \multicolumn{8}{|c|}{$\begin{array}{l}\text { Table } 15 \\
\text { Plan F-1, Guard Wall Impact Experiments }\end{array}$} \\
\hline \multicolumn{8}{|c|}{ Total Riverflow $=335,000$ cfs, First Powerhouse $Q=140,000$ cfs, Upper Pool el 71.5} \\
\hline \multirow[b]{2}{*}{$\begin{array}{l}\text { Run } \\
\text { No. }\end{array}$} & \multicolumn{7}{|c|}{ Loss of Power at Dike 1} \\
\hline & Dike 4 & Dike 3 & Dike 2 & Dike 1 & Dike 1-A & Guidewall & $\begin{array}{l}\text { Impact @ } \\
\text { Station }\end{array}$ \\
\hline $1^{1}$ & $7.0 /-12.6$ & $6.1 /-5.8$ & $5.3 /-.08$ & $4.6 / 2.0$ & $5.1 / 3.8$ & $3.6 / 13.1$ & $15+49$ \\
\hline 2 & $6.2 /-18.6$ & $5.9 /-12.5$ & $4.9 /-8.4$ & $5.0 /-5.0$ & $5.2 /-1.9$ & $3.4 / 7.1$ & $15+79$ \\
\hline 3 & $8.0 /-15.6$ & $8.2 /-11.6$ & $7.2 /-8.5$ & $5.9 /-6.2$ & $6.1 /-4.6$ & $3.7 /-0.3$ & $14+78$ \\
\hline 4 & $8.0 /-15.1$ & $8.0 /-10.6$ & $7.2 /-6.7$ & $6.2 /-3.7$ & $6.5 /-1.8$ & $4.1 / 5.6$ & $16+69$ \\
\hline 5 & $8.3 /-20.3$ & $8.4 /-13.5$ & $6.7 /-8.6$ & $6.1 /-4.7$ & $6.5 /-1.8$ & $4.4 / 7.6$ & $14+79$ \\
\hline 6 & $8.4 /-16.9$ & $8.1 /-11.3$ & $6.9 /-5.3$ & $6.1 /-2.4$ & $6.4 /-0.6$ & $3.5 / 2.9$ & $19+12$ \\
\hline 7 & $7.6 /-15.7$ & $7.6 /-10.6$ & $6.6 /-6.9$ & $5.7 /-4.9$ & $6.0 /-2.5$ & $3.8 / 6.1$ & $16+79$ \\
\hline 8 & 8.0/-19.0 & $7.1 /-13.2$ & $6.0 /-7.3$ & $5.2 /-4.2$ & $5.7 /-1.4$ & $2.0 / 0.9$ & $17+78$ \\
\hline 9 & $8.1 /-12.1$ & $8.3 /-7.1$ & $7.8 /-3.4$ & $6.1 /-1.4$ & $6.5 / 0.0$ & $3.1 / 5.9$ & $16+77$ \\
\hline 10 & $7.7 /-16.4$ & $8.0 /-12.5$ & $6.5 /-10.2$ & $5.6 /-9.1$ & $5.7 /-8.5$ & $2.5 /-4.2$ & $16+79$ \\
\hline
\end{tabular}

7.2/9.0 represents $7.2 \mathrm{fps}$ velocity and 9.0 deg rotation of tow relative to the center line of lock when head of tow is at selected point. Positive angle is rotation toward the guard wall.

\section{Table 16 \\ Plan F-1, Guard Wall Impact Experiments}

Total Riverflow $=335,000$ cfs, First Powerhouse $Q=140,000$ cfs, Upper Pool el 71.5

\begin{tabular}{||l|l|l|l|l|l|l|l||}
\hline \multirow{3}{*}{$\begin{array}{l}\text { Run } \\
\text { No. }\end{array}$} & \multicolumn{7}{|c||}{ Loss of Power at Dike 2 } \\
\cline { 2 - 8 } & Dike 4 & Dike 3 & Dike 2 & Dike 1 & Dike 1-A & Guidewall & $\begin{array}{l}\text { Impact @ } \\
\text { Station }\end{array}$ \\
\hline \hline 11 & $6.2 /-20.8$ & $4.1 /-16.4$ & $3.3 /-11.1$ & $4.0 /-6.3$ & $4.2 /-5.6$ & $1.0 /-3.7$ & $17+93$ \\
\hline 2 & $8.4 /-19.0$ & $7.2 /-13.8$ & $5.6 /-9.0$ & $5.5 /-7.7$ & $5.8 /-7.2$ & $1.1 /-2.7$ & $19+26$ \\
\hline 3 & $5.8 /-11.9$ & $4.7 /-5.9$ & $3.8 /-1.5$ & $4.0 / 4.5$ & $4.5 / 5.9$ & $3.4 / 14.8$ & $15+76$ \\
\hline 4 & $7.4 /-5.7$ & $8.2 /-4.7$ & $6.8 /-4.9$ & $6.7 /-5.3$ & $6.5 /-5.9$ & $1.6 /-2.3$ & $19+88$ \\
\hline 5 & $7.8 /-15.4$ & $7.9 /-11.1$ & $6.8 /-7.1$ & $6.3 /-2.7$ & $6.8 /-0.6$ & $3.9 / 6.2$ & $16+21$ \\
\hline 6 & $7.7 /-17.5$ & $7.4 /-10.5$ & $6.0 /-7.1$ & $5.9 /-2.1$ & $5.9 / 1.0$ & $3.8 / 11.3$ & $17+10$ \\
\hline 7 & $7.9 /-19.8$ & $7.6 /-12.9$ & $6.3 /-8.1$ & $5.9 /-3.8$ & $6.4 /-1.1$ & $4.4 / 11.1$ & $17+48$ \\
\hline 8 & $6.1 /-15.9$ & $5.5 /-11.3$ & $4.3 /-7.1$ & $4.6 /-2.4$ & $5.2 / 0.0$ & $1.2 / 2.4$ & $20+28$ \\
\hline 9 & $7.7 /-14.8$ & $6.4 /-10.0$ & $5.5 /-7.1$ & $5.5 /-3.2$ & $5.6 /-0.7$ & $2.3 / 2.0$ & $20+37$ \\
\hline 10 & $7.0 /-16.0$ & $6.3 /-11.7$ & $5.7 /-9.5$ & $5.4 /-7.9$ & $5.8 /-7.5$ & $1.4 /-4.2$ & $18+25$ \\
\hline \hline 7
\end{tabular}

7.2/9.0 represents 7.2 fps velocity and 9.0 deg rotation of tow relative to the center line of lock when head of tow is at selected point. Positive angle is rotation toward the guard wall. 


\begin{tabular}{|c|c|c|c|c|c|c|c|}
\hline \multicolumn{8}{|c|}{$\begin{array}{l}\text { Table } 17 \\
\text { Plan F-1, Guard Wall Impact Experiments }\end{array}$} \\
\hline \multicolumn{8}{|c|}{ Total Riverflow $=335,000$ cfs, First Powerhouse $Q=140,000$ cfs, Upper Pool el 71.5} \\
\hline \multirow[b]{2}{*}{$\begin{array}{l}\text { Run } \\
\text { No. }\end{array}$} & \multicolumn{7}{|c|}{ Loss of Power at Dike 3} \\
\hline & Dike 4 & Dike 3 & Dike 2 & Dike 1 & Dike 1-A & Guidewall & $\begin{array}{l}\text { Impact @ } \\
\text { Station }\end{array}$ \\
\hline $1^{1}$ & $7.1 /-19.6$ & $6.8 /-13.2$ & $6.0 /-7.9$ & $6.0 /-3.3$ & $5.9 /-0.2$ & $2.3 / 8.4$ & $20+27$ \\
\hline 2 & $6.9 /-15.9$ & $6.8 /-9.7$ & $6.4 /-5.5$ & $6.2 /-1.3$ & $6.2 / 0.9$ & $4.4 / 11.6$ & $17+08$ \\
\hline 3 & $7.2 /-17.3$ & $7.2 /-11.1$ & $6.6 /-5.8$ & $6.1 /-0.3$ & $6.5 / 3.1$ & $4.7 / 15.5$ & $16+26$ \\
\hline 4 & $7.9 /-13.4$ & $7.2 /-9.2$ & $6.7 /-6.1$ & $6.3 /-4.2$ & 6.3/-3.3 & $1.4 / 4.9$ & $20+27$ \\
\hline 5 & $7.2 /-12.8$ & $6.5 /-8.6$ & $6.2 /-5.2$ & $5.8 /-3.1$ & $6.0 /-1.8$ & $1.7 / 5.1$ & $20+25$ \\
\hline 6 & 7.3/-17.8 & $6.8 /-11.7$ & $6.1 /-6.9$ & $6.0 /-3.2$ & $6.2 /-1.5$ & $4.9 / 7.1$ & $16+44$ \\
\hline 7 & $6.4 /-12.1$ & $6.3 /-9.0$ & $5.8 /-5.0$ & $5.4 /-1.2$ & $5.7 / 0.2$ & $1.2 / 7.1$ & $20+22$ \\
\hline 8 & $8.9 /-16.7$ & $7.4 /-10.2$ & $6.6 /-5.9$ & $5.9 /-2.2$ & $6.5 /-0.2$ & $1.6 / 6.8$ & $20+28$ \\
\hline 9 & $7.9 /-12.5$ & 8.0/-9.1 & $7.3 /-6.7$ & $6.5 /-3.6$ & $7.1 /-0.8$ & $1.9 / 10.6$ & $20+16$ \\
\hline 10 & $7.3 /-16.0$ & $7.3 /-10.1$ & $6.7 /-6.0$ & 6.3/-3.0 & $6.6 /-1.4$ & $4.6 / 5.6$ & $17+05$ \\
\hline
\end{tabular}

17.2/9.0 represents $7.2 \mathrm{fps}$ velocity and 9.0 deg rotation of tow relative to the center line of lock when head of tow is at selected point. Positive angle is rotation toward the guard wall.

\section{Table 18 \\ Plan F-1, Guard Wall Impact Experiments}

\begin{tabular}{|c|c|c|c|c|c|c|c|}
\hline \multicolumn{8}{|c|}{ Total Riverflow $=335,000$ cfs, First Powerhouse $Q=140,000$ cfs, Upper Pool el 71.5} \\
\hline \multirow[b]{2}{*}{$\begin{array}{l}\text { Run } \\
\text { No. }\end{array}$} & \multicolumn{7}{|c|}{ Loss of Power at Dike 4} \\
\hline & Dike 4 & Dike 3 & Dike 2 & Dike 1 & Dike 1-A & Guidewall & $\begin{array}{l}\text { Impact @ } \\
\text { Station }\end{array}$ \\
\hline $1^{1}$ & 7.8/-13.6 & 7.5/-3.7 & 7.1/4.1 & $6.1 / 9.8$ & $6.6 / 9.1$ & $3.3 / 7.8$ & $20+19$ \\
\hline 2 & 7.3/-12.8 & $6.9 /-5.3$ & $6.5 /-1.7$ & 6.0/8.3 & $5.9 / 12.1$ & $4.3 / 21.5$ & $14+22$ \\
\hline 3 & $6.9 /-12.5$ & $6.8 /-4.9$ & $6.1 / 2.7$ & $5.9 / 10.6$ & $6.1 / 14.0$ & $5.4 / 21.7$ & $14+21$ \\
\hline 4 & $6.4 /-13.3$ & $6.5 /-5.9$ & $5.9 / 0.2$ & $5.8 / 6.9$ & $5.9 / 9.9$ & $4.7 / 20.2$ & $14+95$ \\
\hline 5 & $5.5 /-13.1$ & $5.6 /-8.5$ & $5.4 /-3.7$ & $5.1 / 0.3$ & $5.5 / 2.2$ & $4.0 / 10.9$ & $17+18$ \\
\hline 6 & 7.8/-15.0 & $7.5 /-9.5$ & $6.5 /-5.5$ & $5.6 /-1.5$ & $5.7 / 0.2$ & $2.8 / 7.9$ & $17+80$ \\
\hline 7 & 7.6/-15.4 & 7.1/-9.6 & $5.8 /-5.1$ & $5.2 /-2.6$ & $5.2 /-0.2$ & $1.3 /-4.0$ & $19+00$ \\
\hline 8 & $7.7 /-12.4$ & $7.7 /-4.5$ & 6.8/3.3 & $6.6 / 12.1$ & 6.4/16.3 & $3.3 / 21.4$ & $14+63$ \\
\hline 9 & $5.4 /-10.2$ & $5.8 /-3.9$ & $5.3 / 2.5$ & $5.1 / 10.5$ & $5.3 / 13.7$ & $1.7 / 4.6$ & $18+00$ \\
\hline 10 & $8.1 /-18.4$ & $7.7 /-10.4$ & $6.9 /-2.9$ & $6.4 / 5.0$ & $6.6 / 8.5$ & $3.8 / 10.6$ & $18+50$ \\
\hline
\end{tabular}

1 7.2/9.0 represents $7.2 \mathrm{fps}$ velocity and 9.0 deg rotation of tow relative to the center line of lock when head of tow is at selected point. Positive angle is rotation toward the guard wall. 


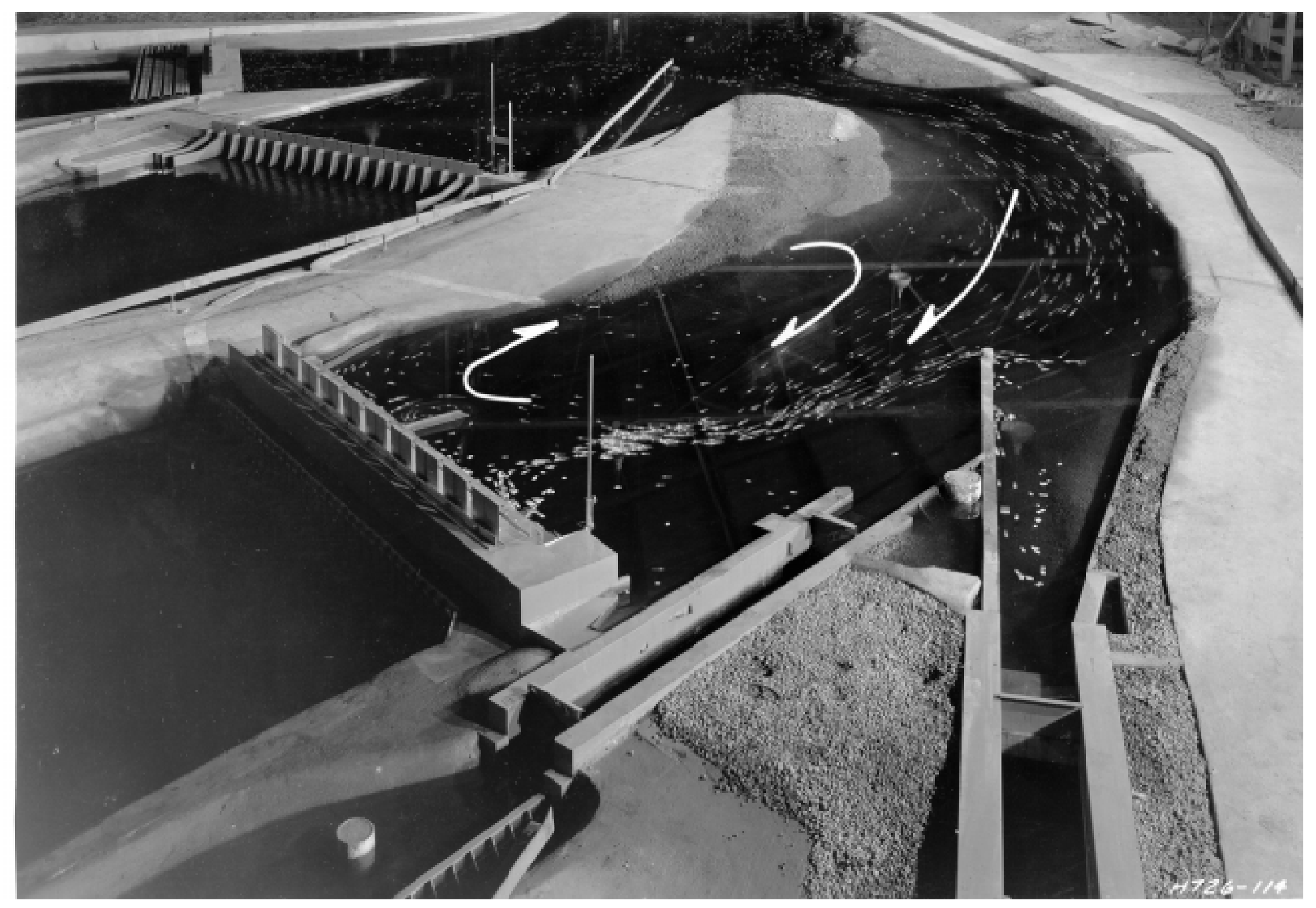

Photo 1. Original design, looking upstream, confetti showing current pattern in lock approach 


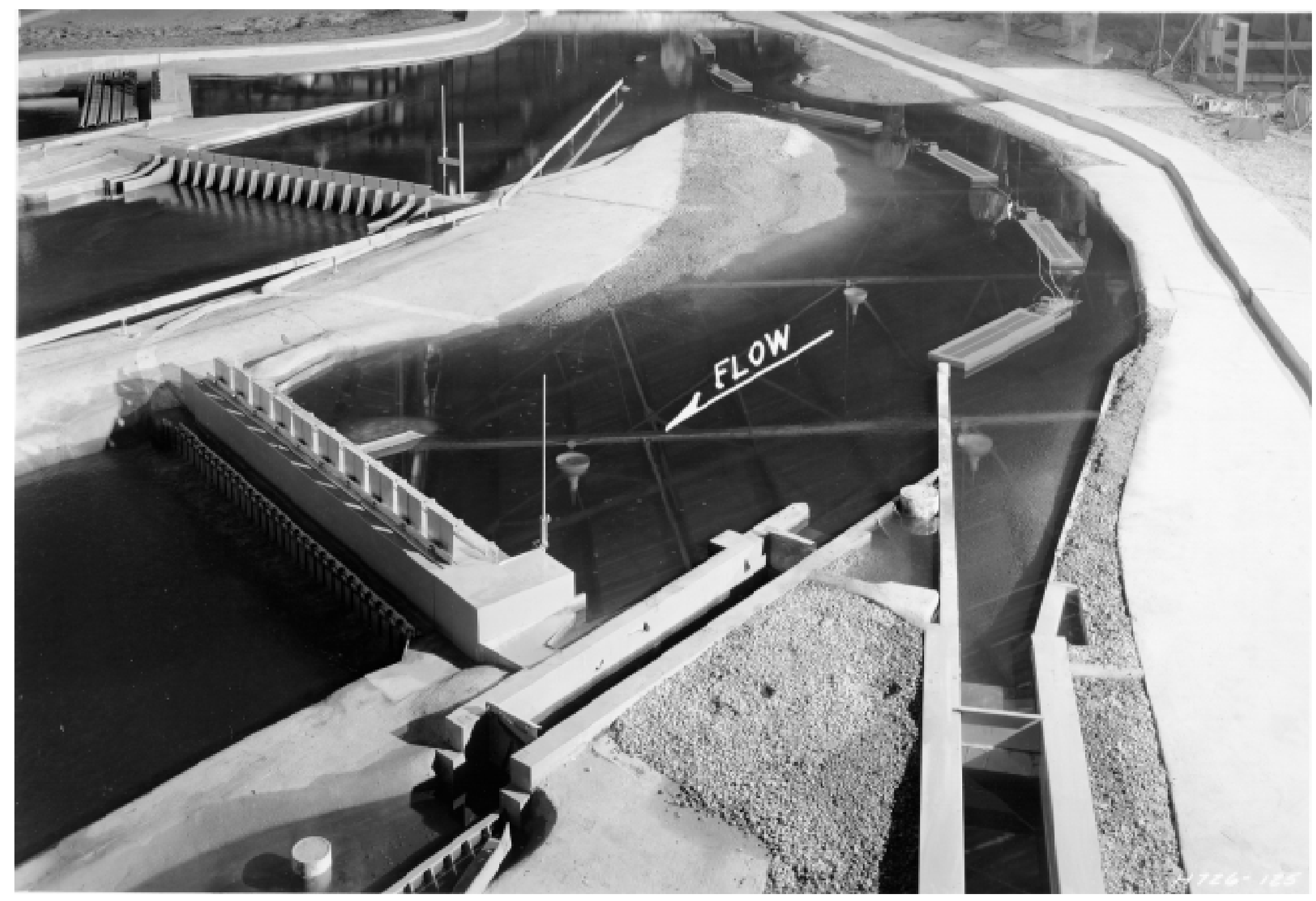

Photo 2. Original design, looking upstream, showing path of downbound tow approaching lock 


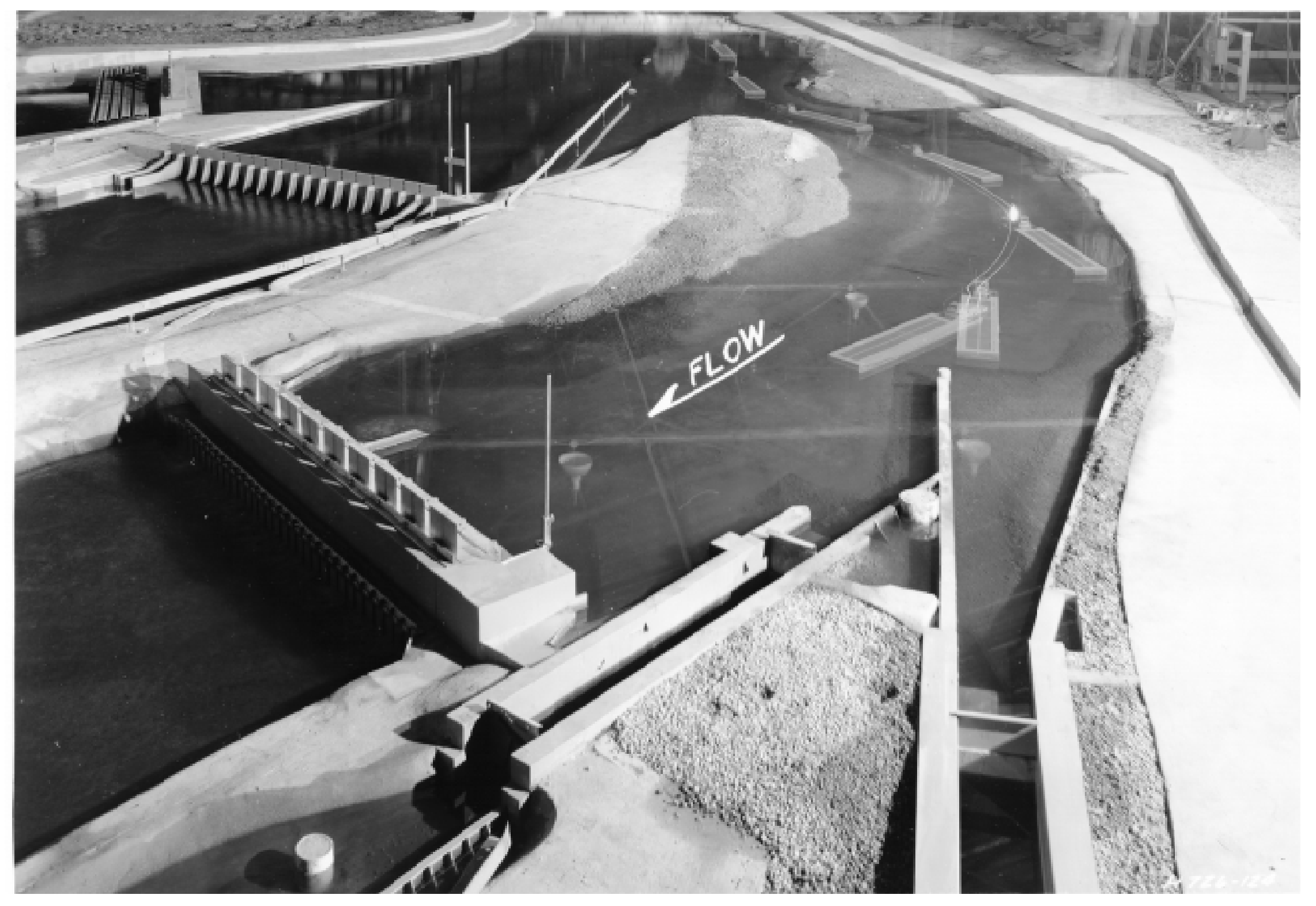

Photo 3. Original design, looking upstream, showing path of downbound tow approaching new lock 


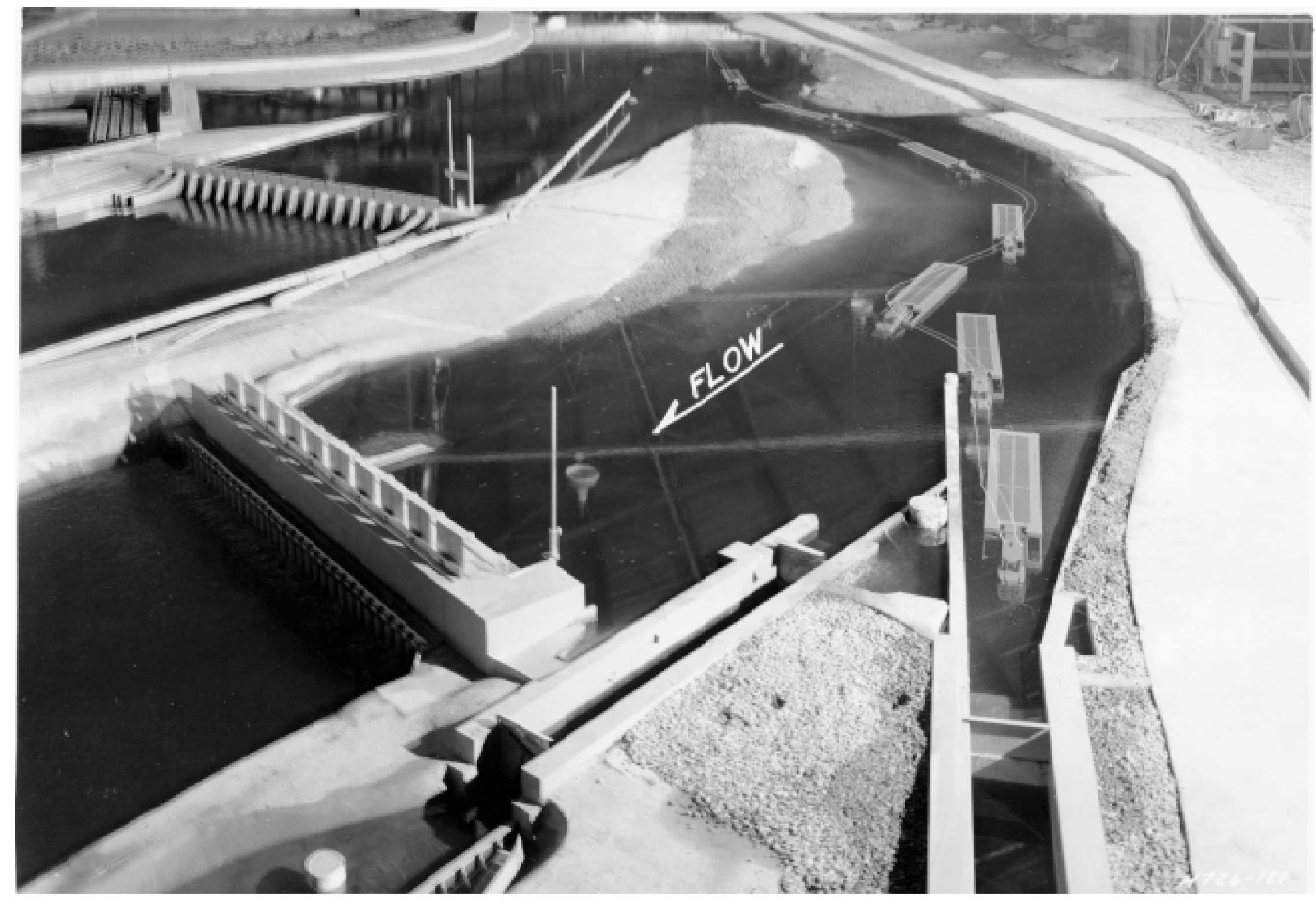

Photo 4. Original design, looking upstream, showing path of tow leaving new lock 


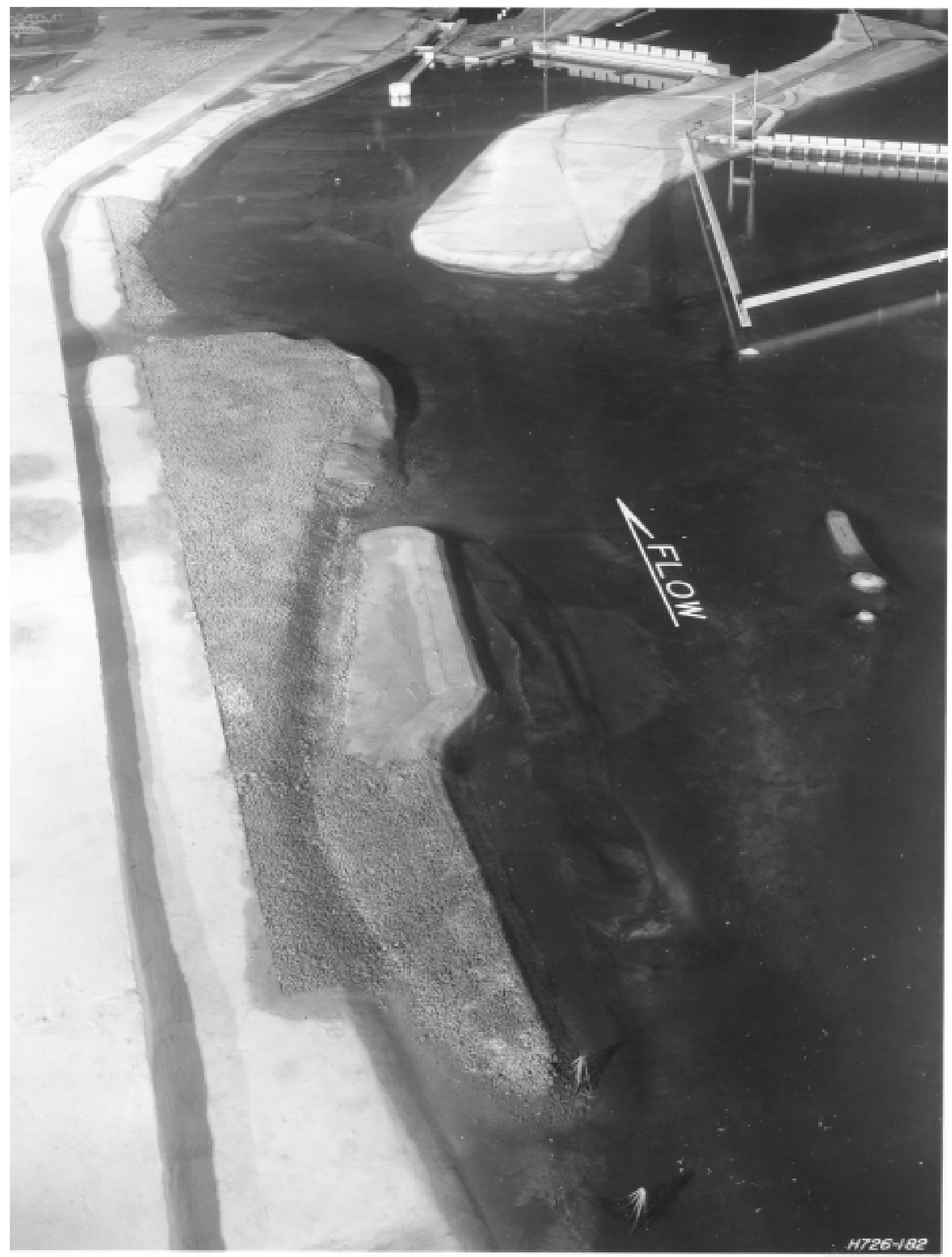

Photo 5. Plan F, looking downstream showing channel alignment 


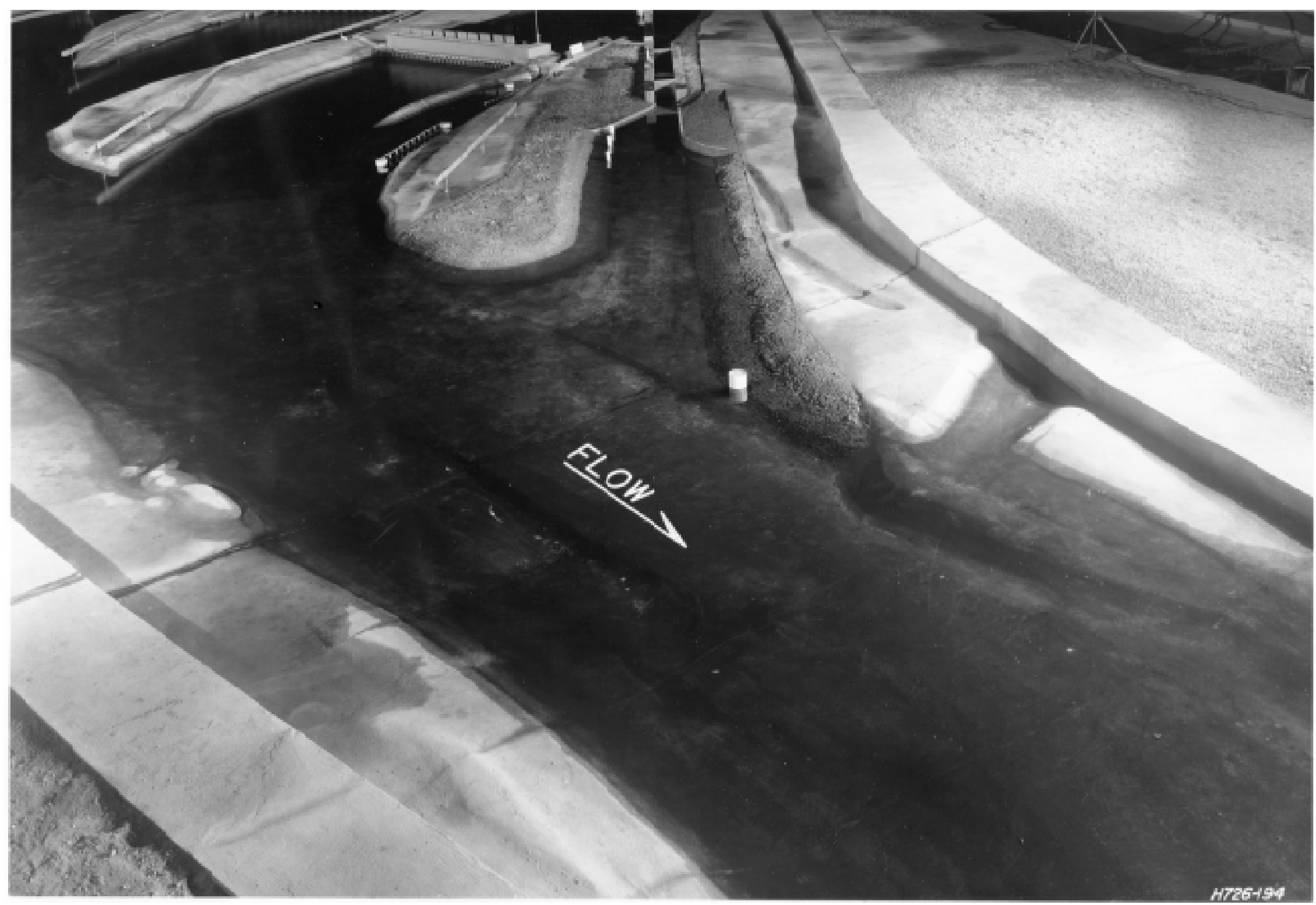

Photo 6. Plan F, looking upstream, showing lower approach of new lock 


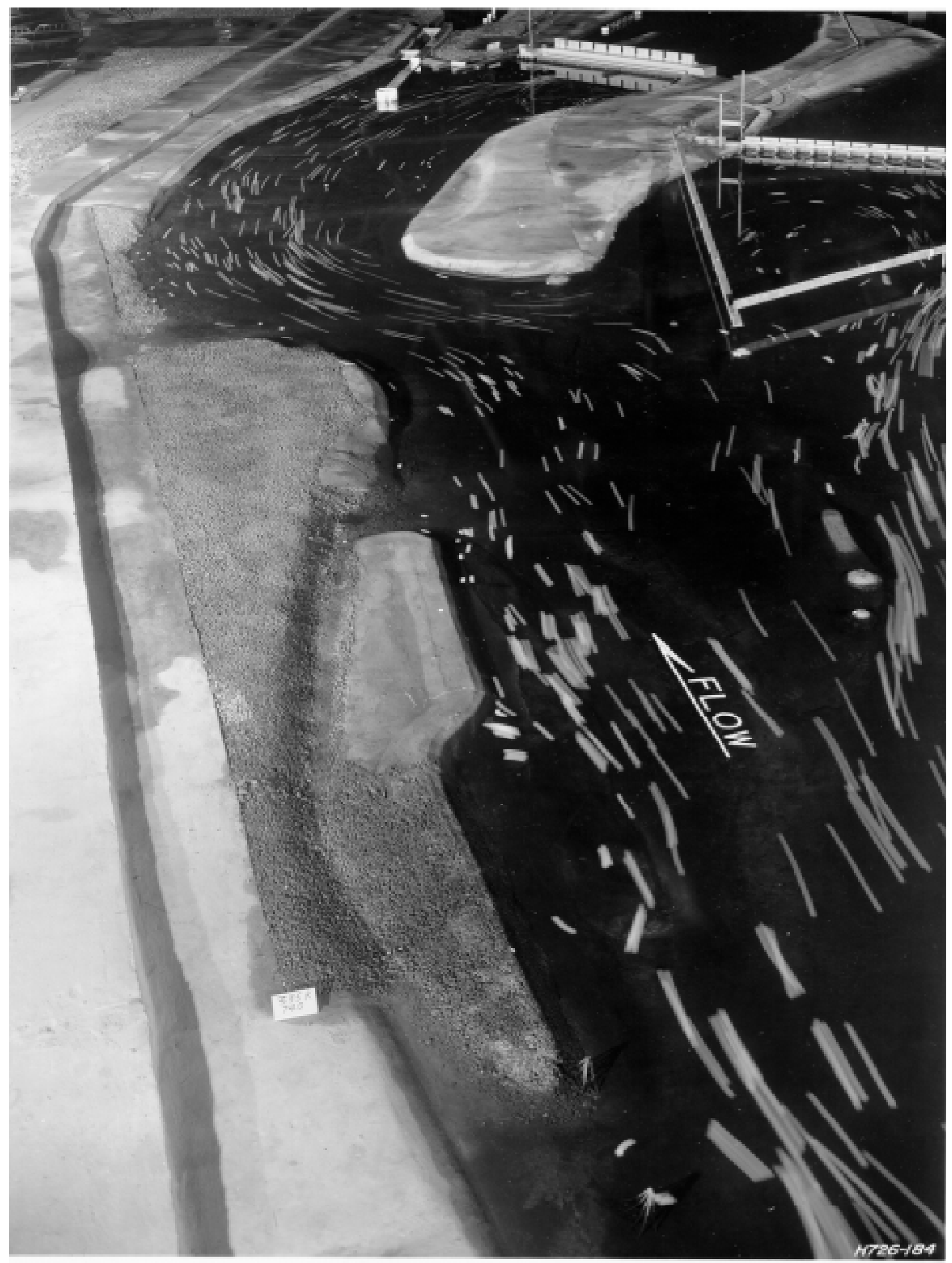

Photo 7. Plan F, 335,000 cfs, looking downstream, confetti showing current pattern 


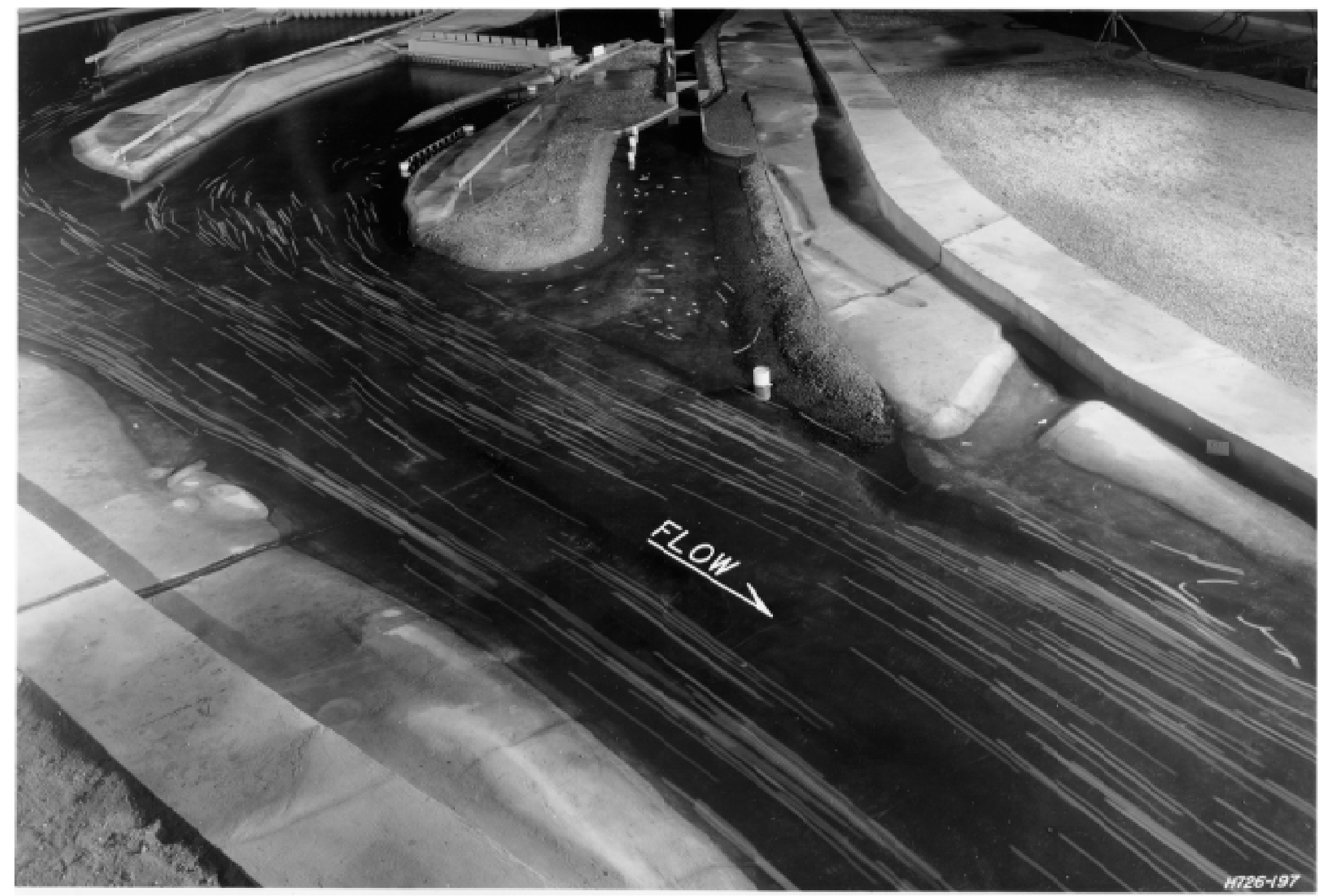

Photo 8. Plan F, looking upstream, 335,000 cfs total riverflow, confetti showing current pattern in vicinity of lock canal 


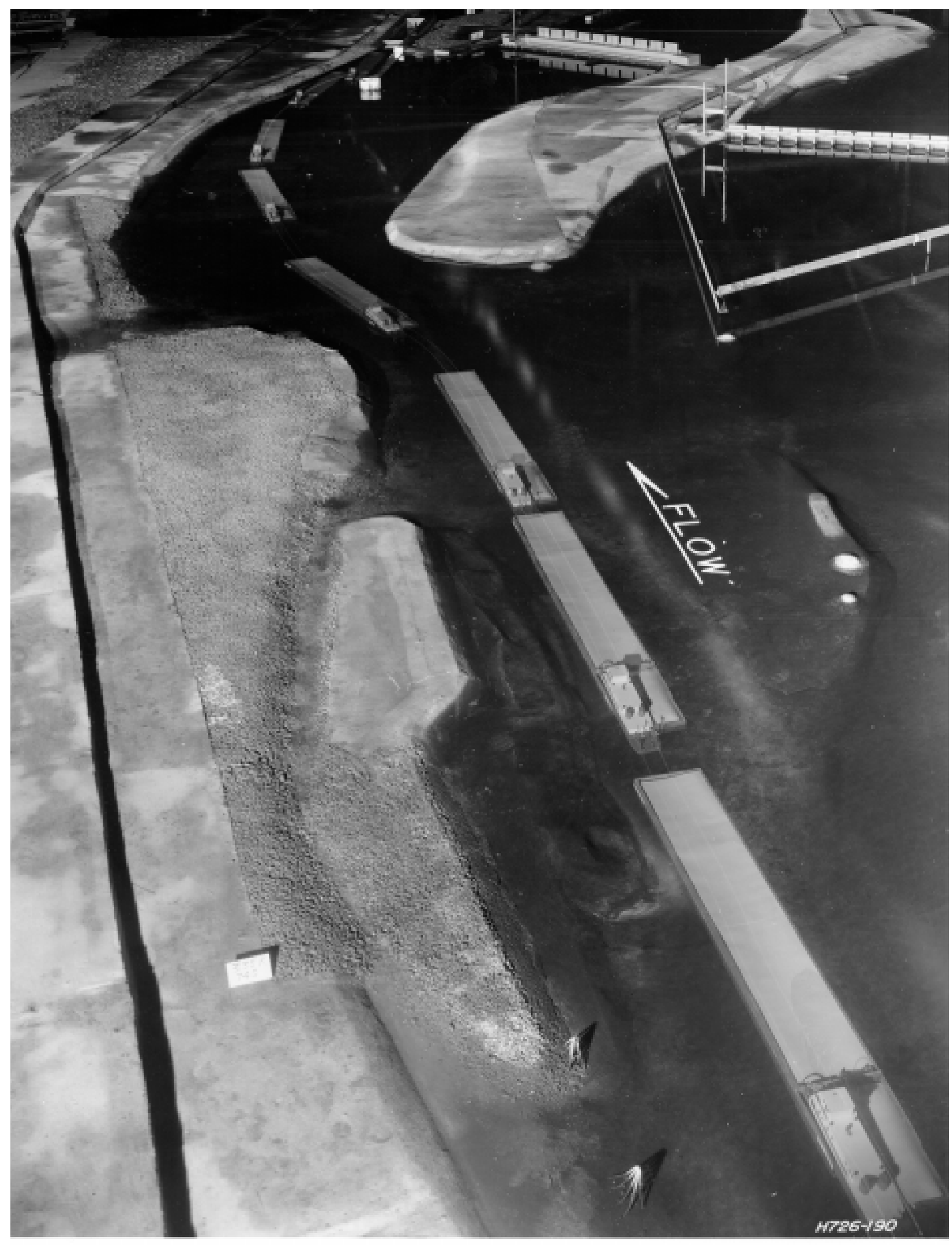

Photo 9. Plan F, 335,000 cfs total riverflow, 140,000 cfs first powerhouse discharge, looking downstream, showing path of downbound tow approaching lock 


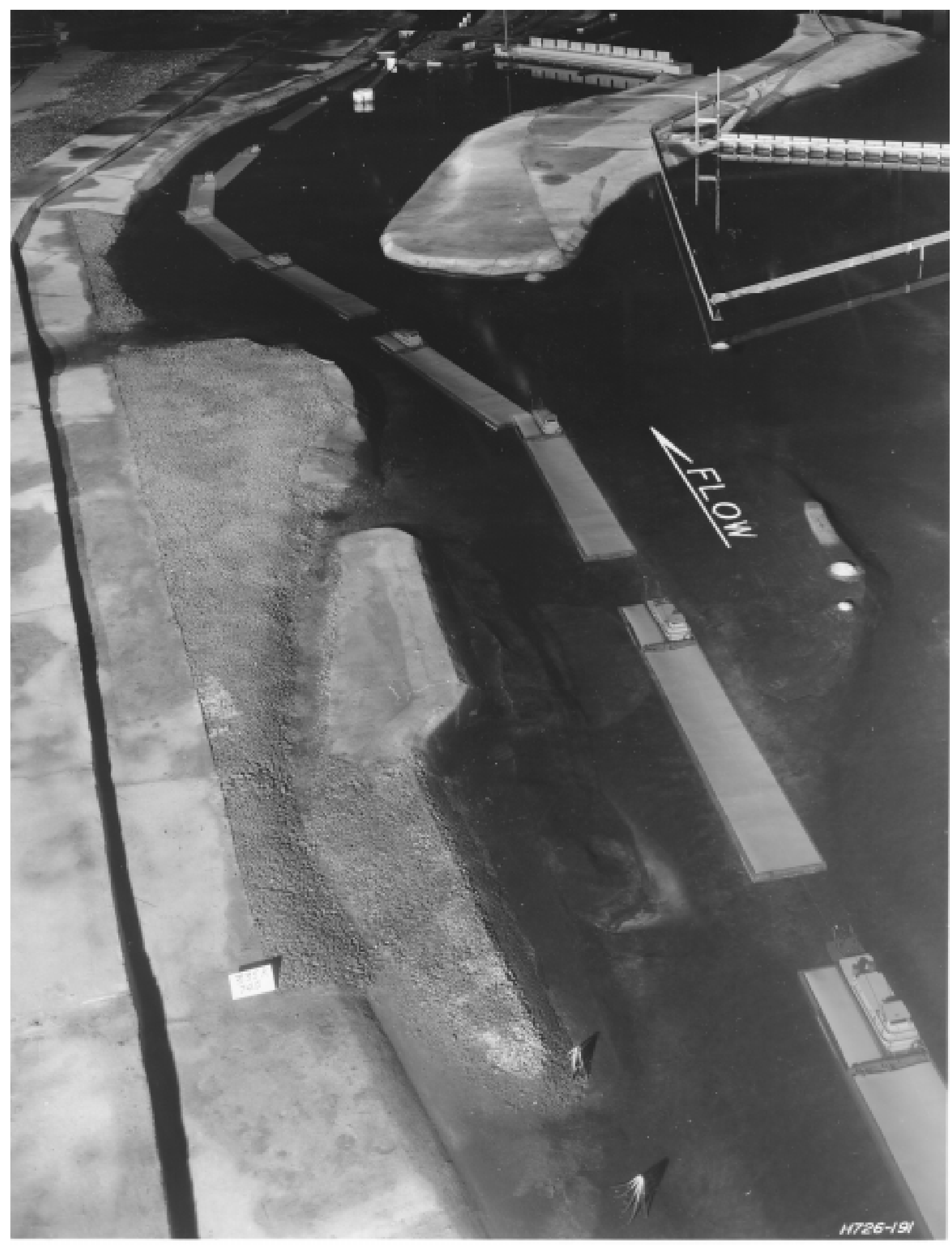

Photo 10. Plan F, 335,000 cfs total riverflow, 140,000 cfs first powerhouse discharge, looking downstream, showing path of upbound tow leaving the new lock 


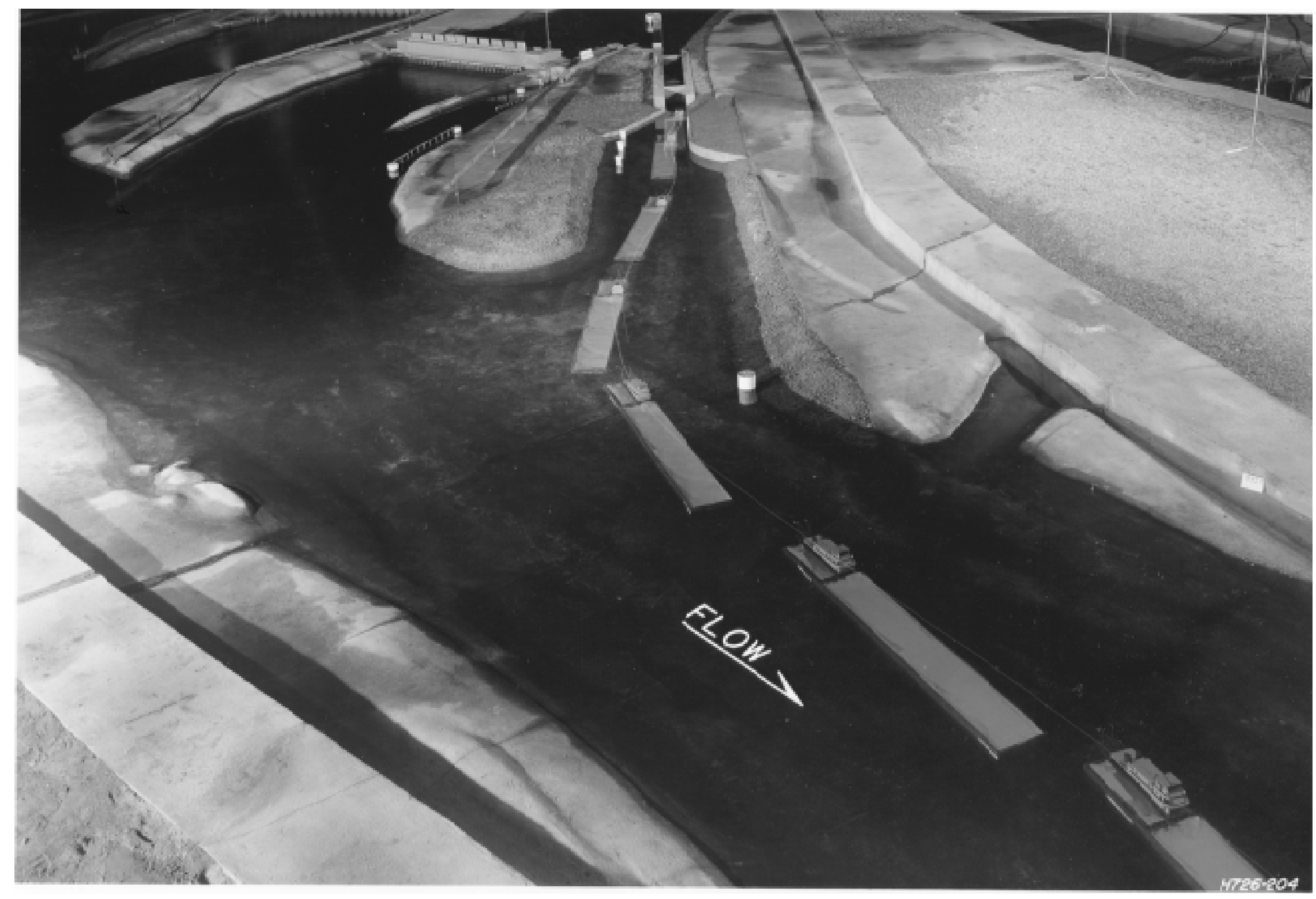

Photo 11. Plan F, looking upstream, 335,000 cfs total riverflow, showing path of downbound tow leaving new lock 


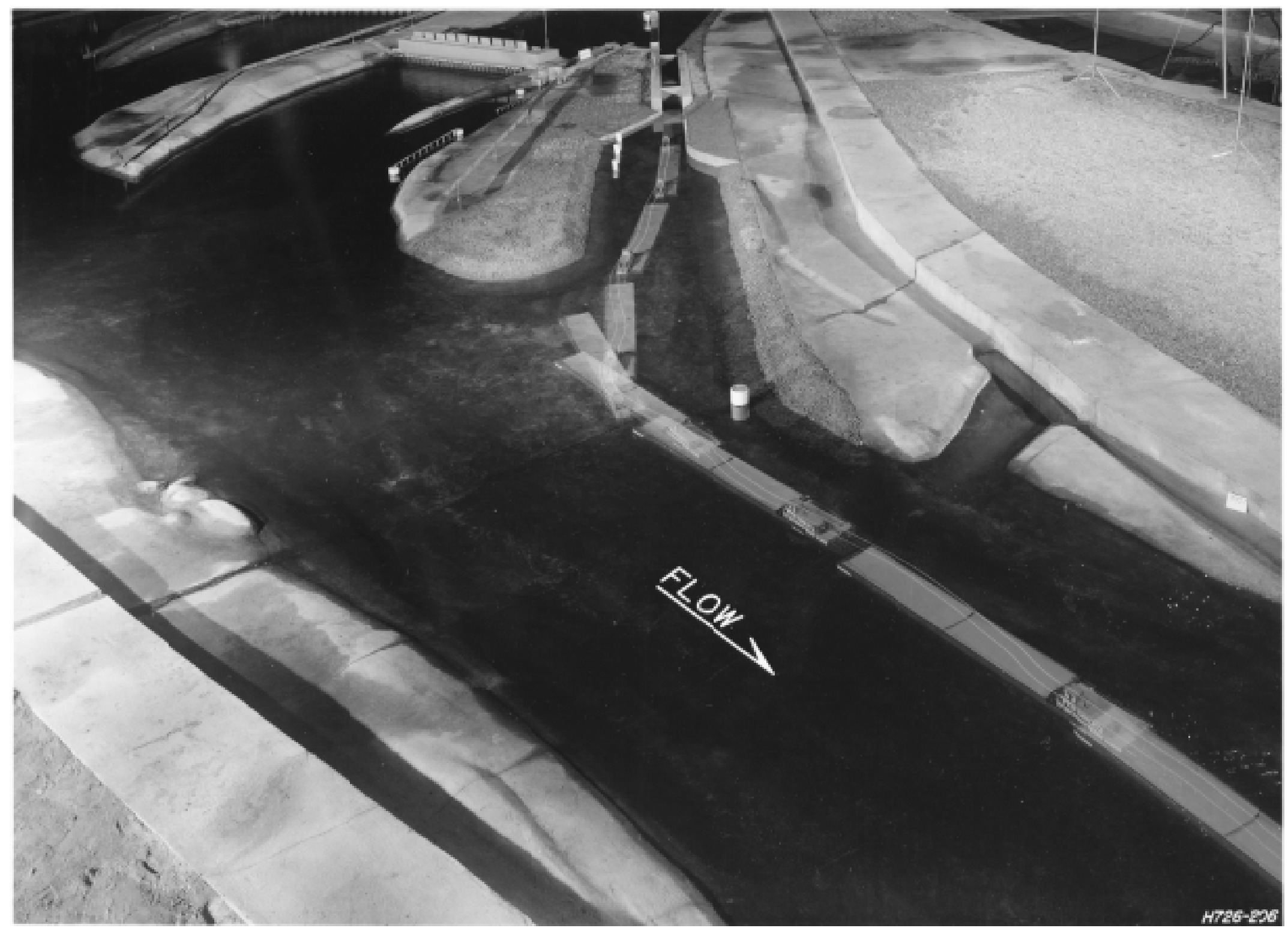

Photo 12. Plan F, looking upstream, 335,000 cfs total riverflow, showing path of upbound tow approaching the new lock 


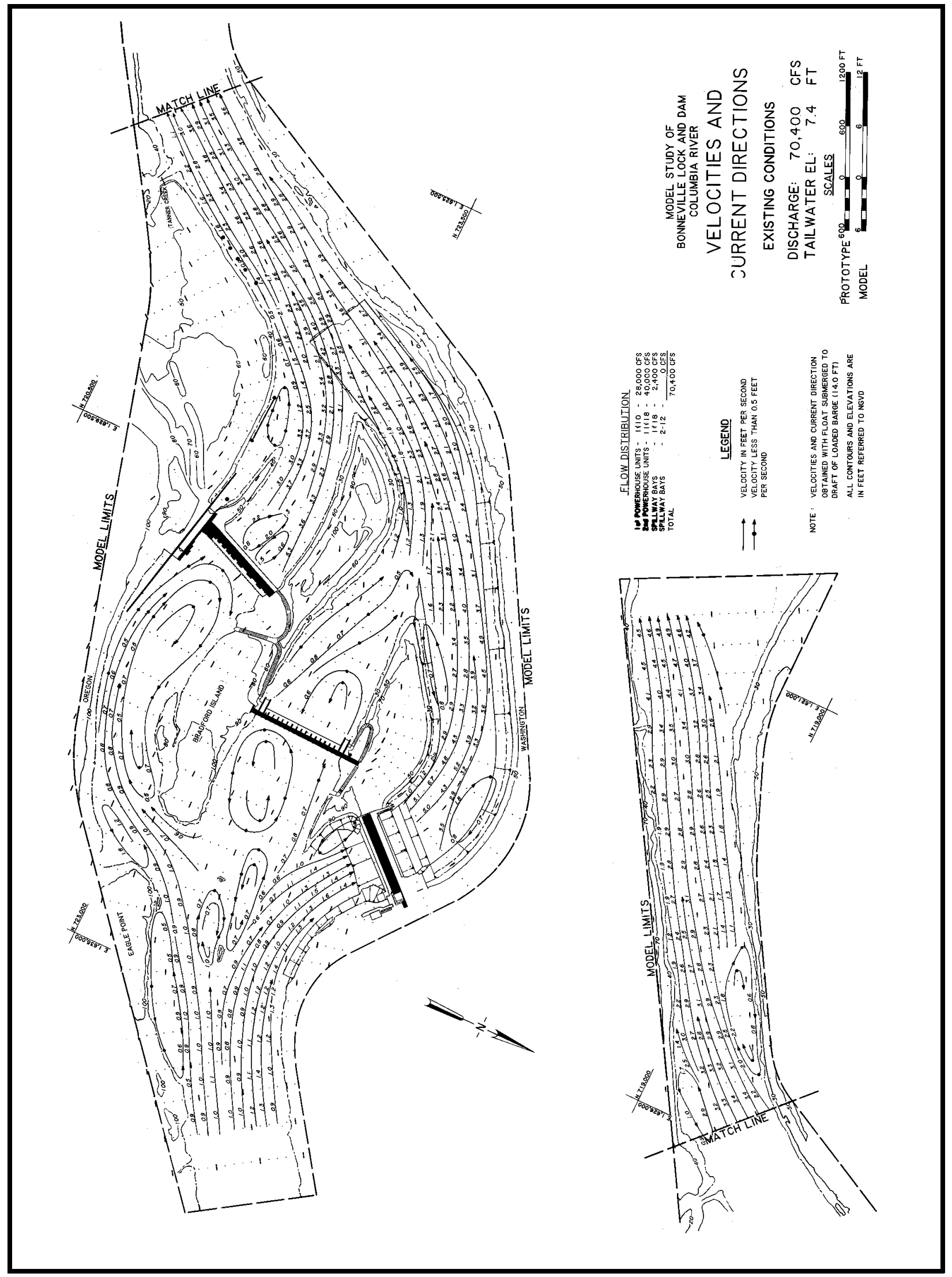

Plate 1 


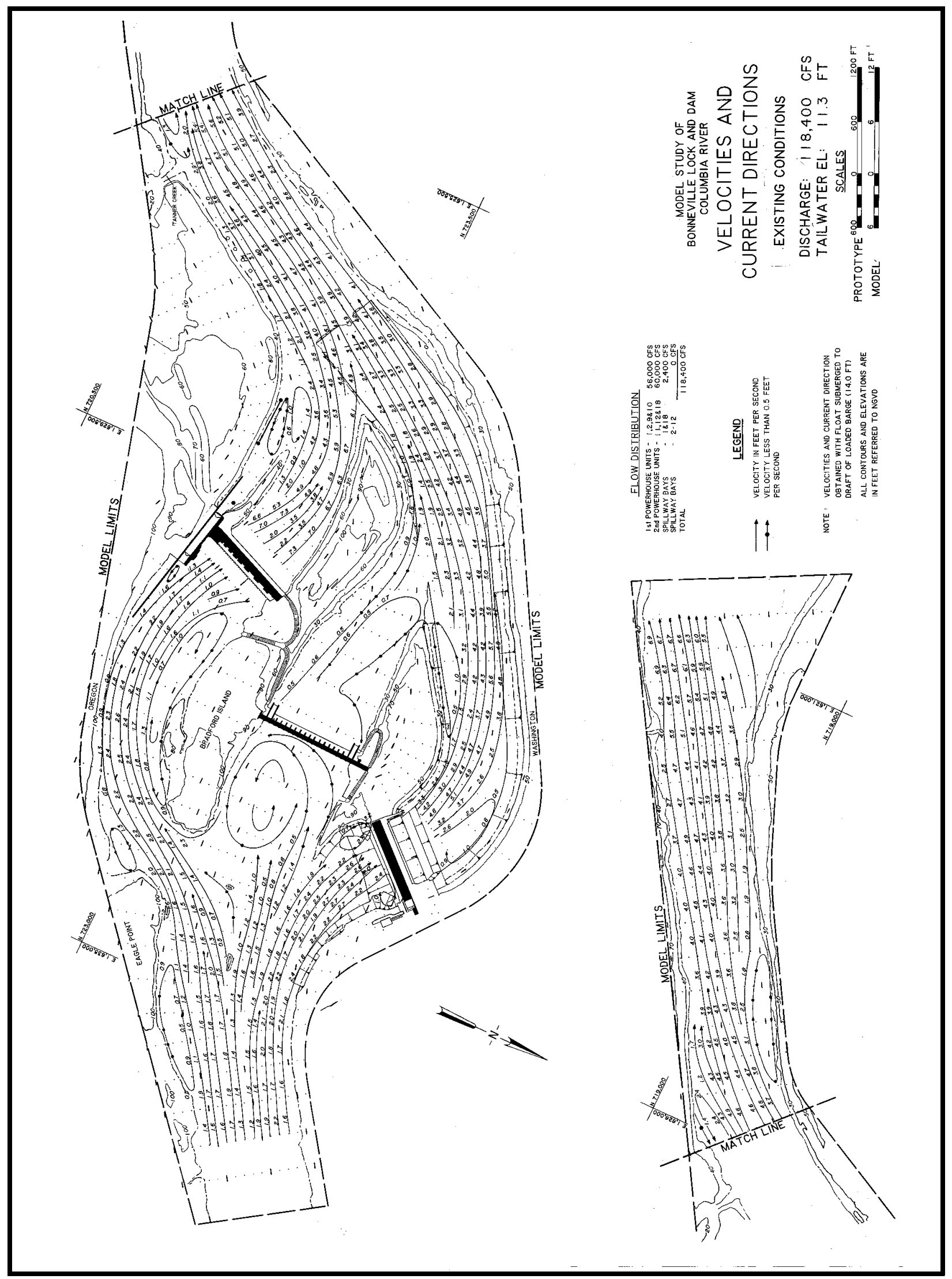

Plate 2 


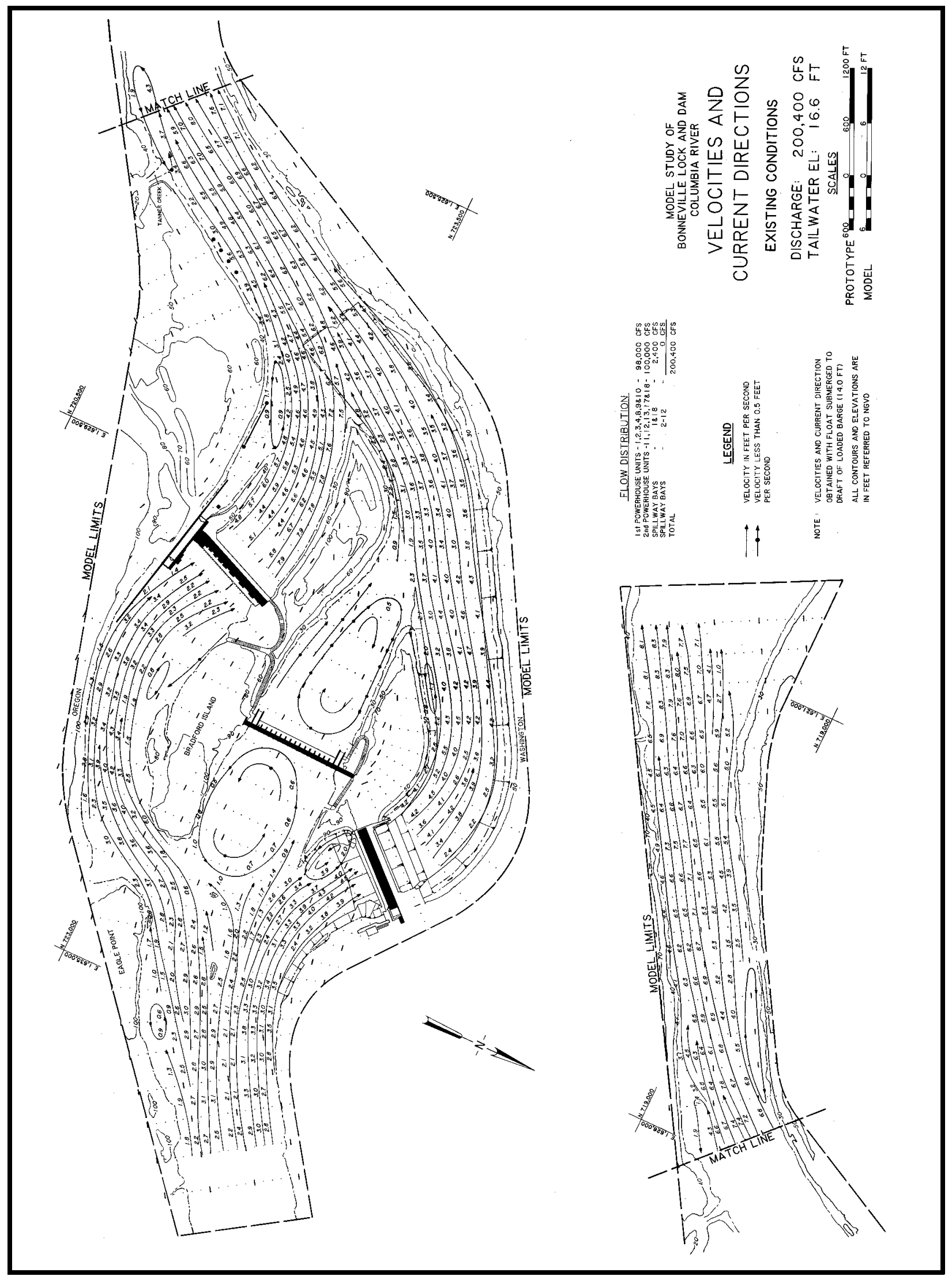

Plate 3 


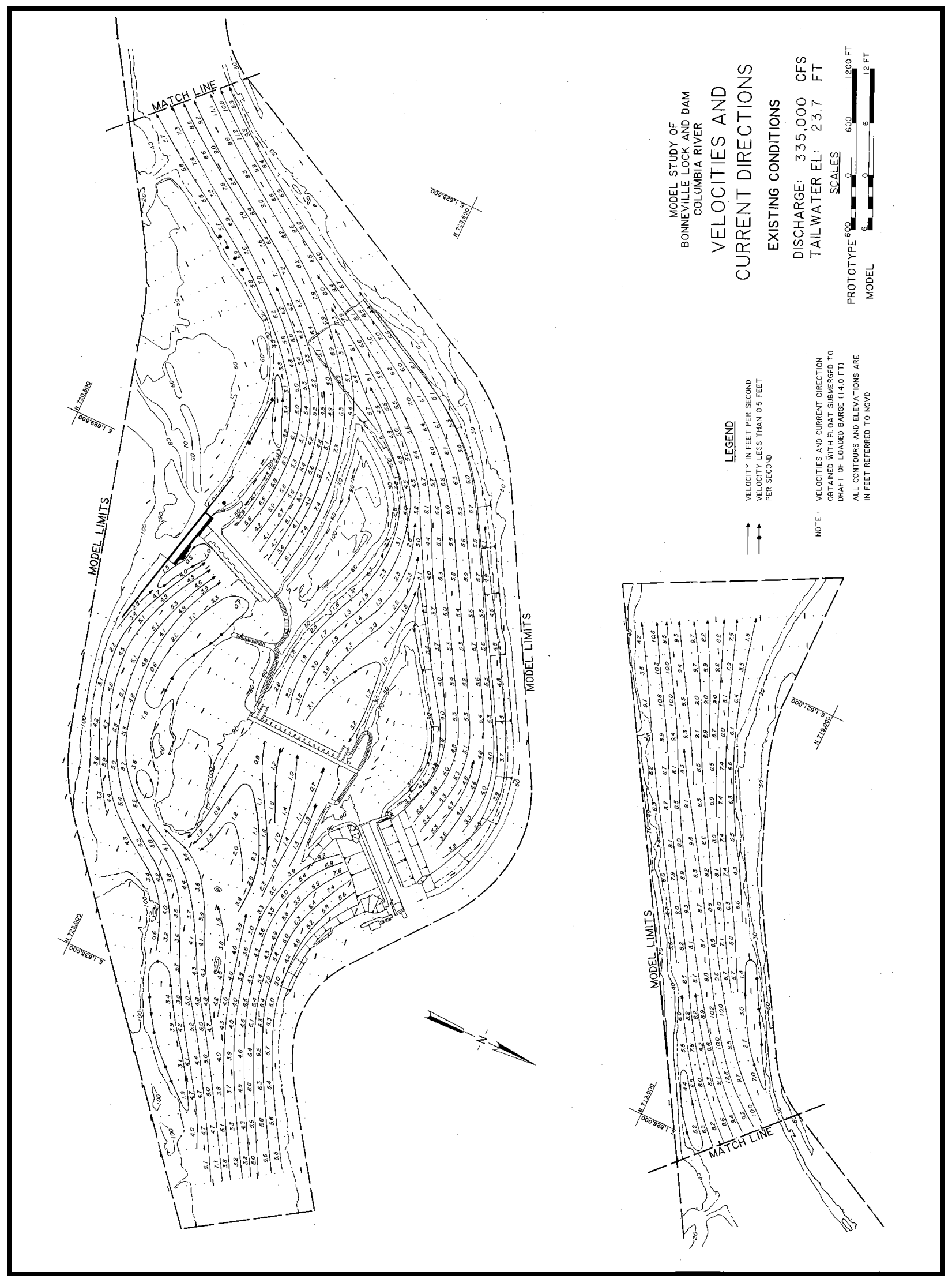

Plate 4 


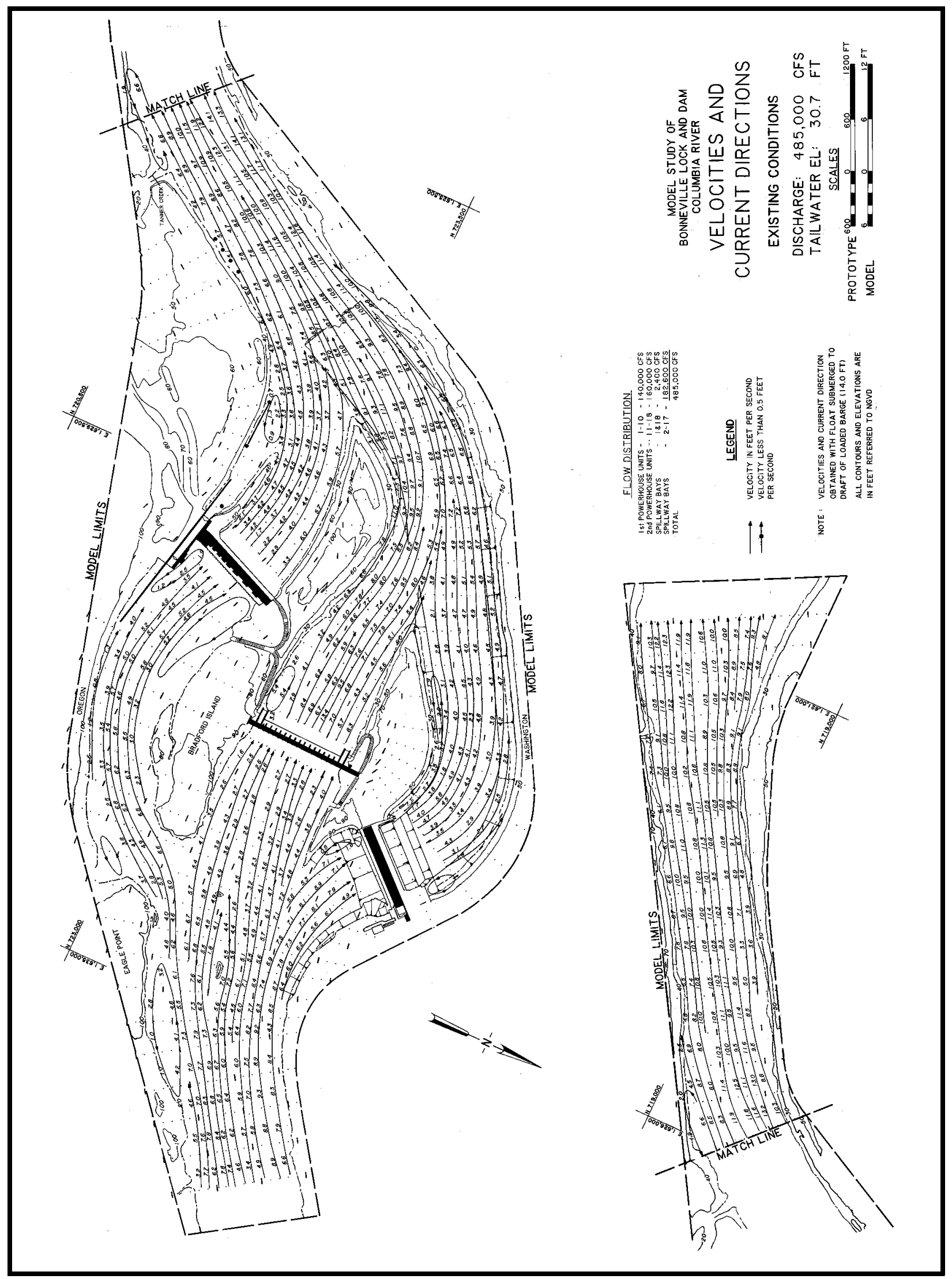

Plate 5 


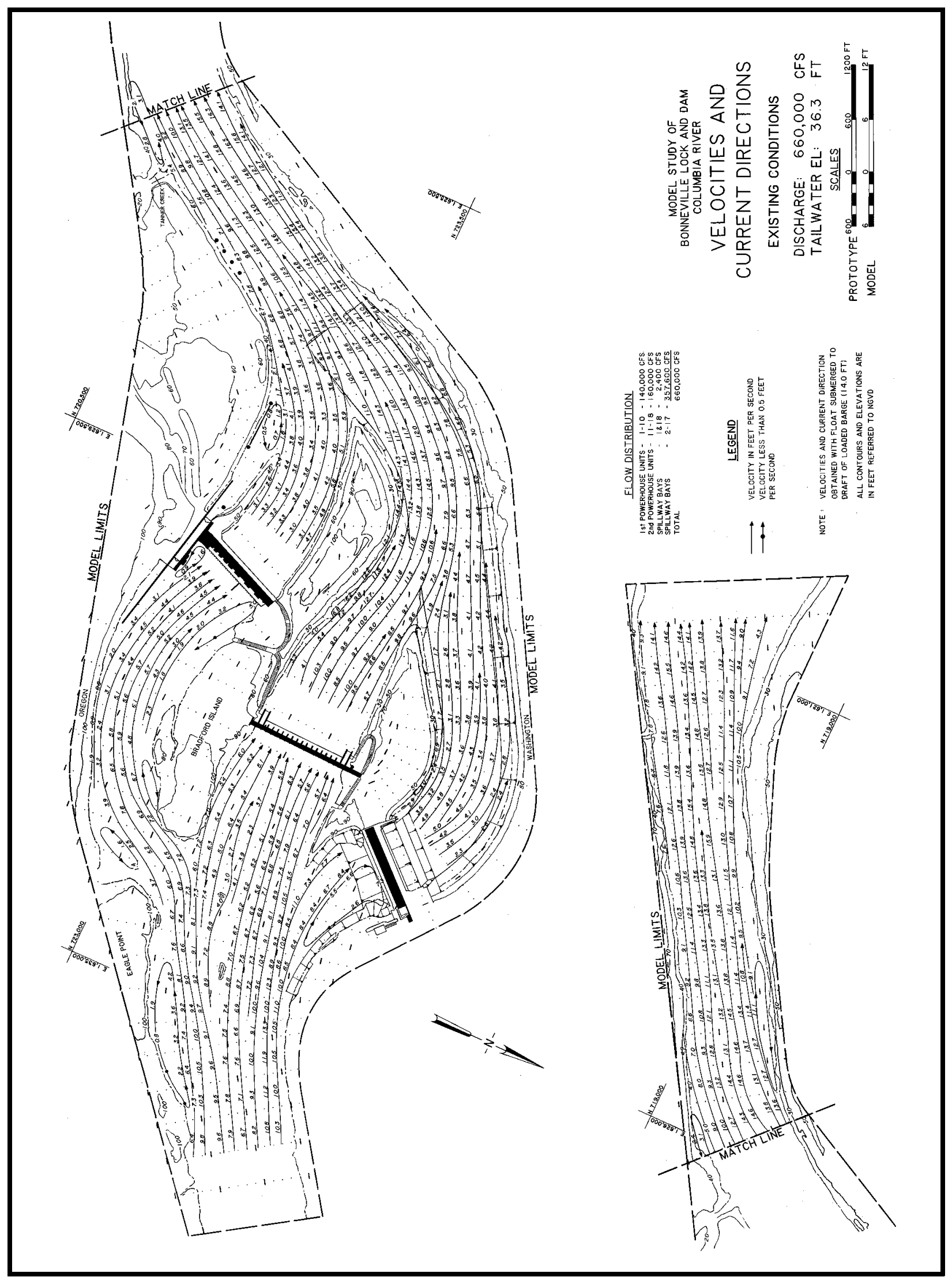

Plate 6 


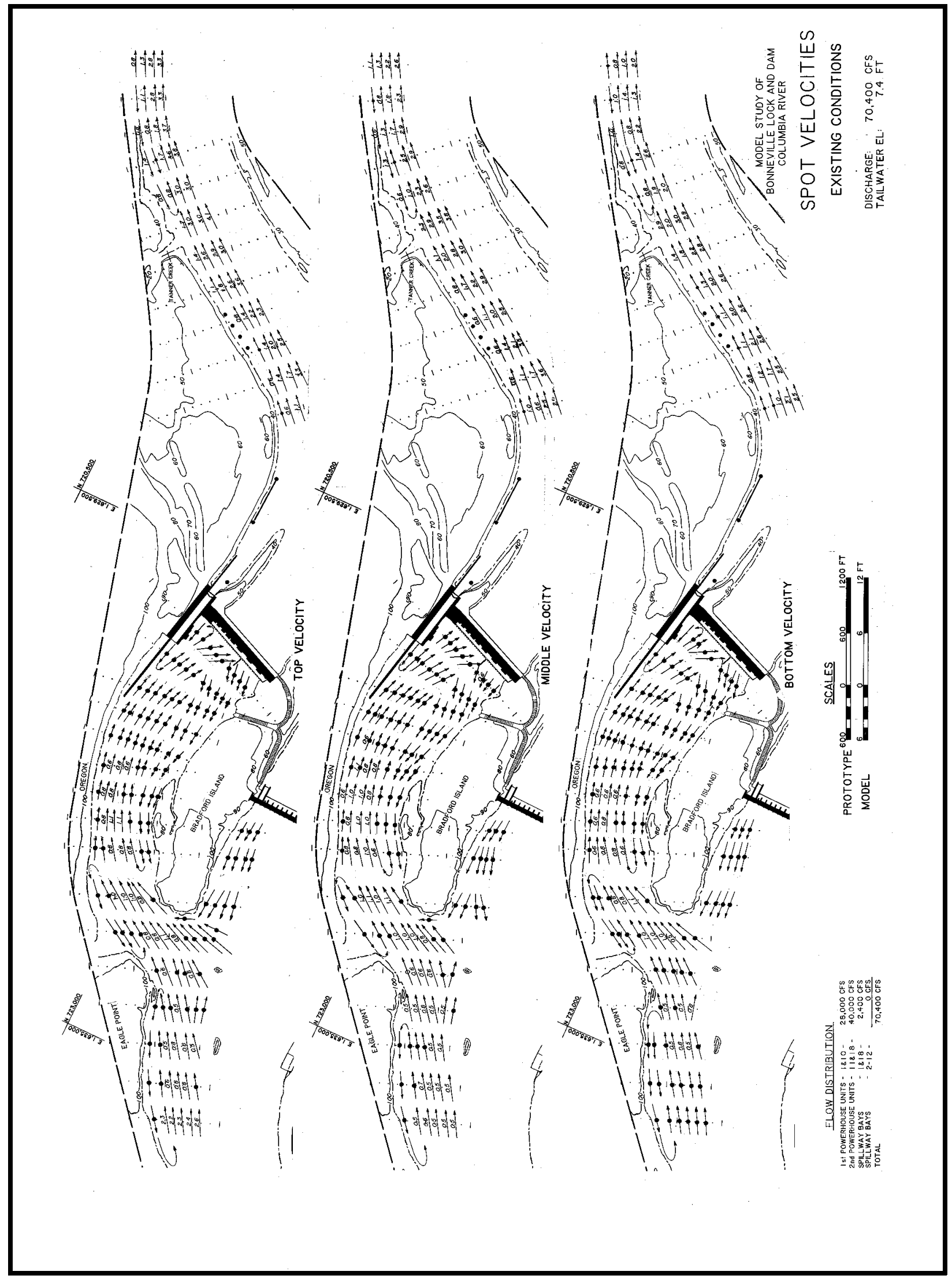

Plate 7 


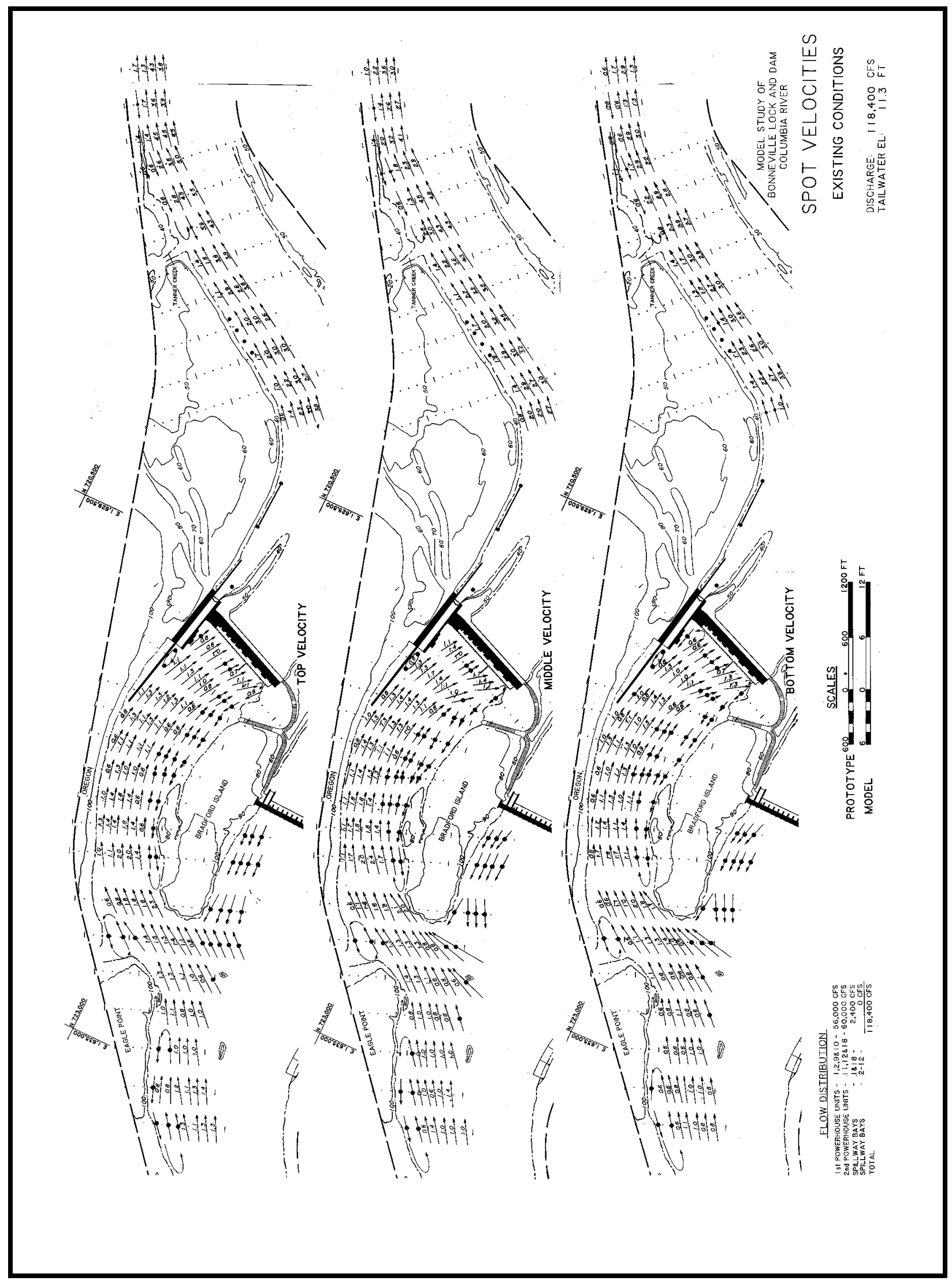

Plate 8 


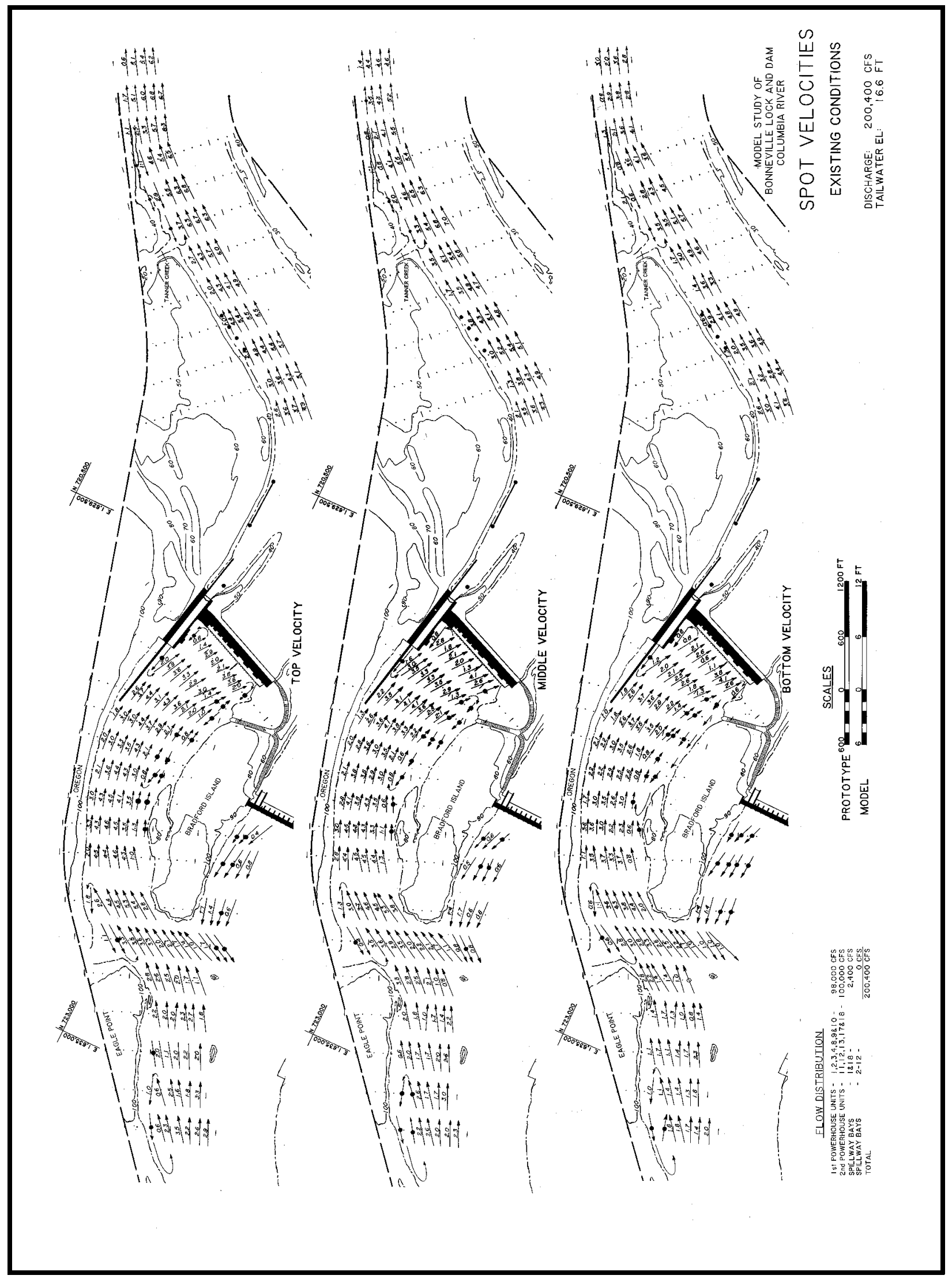

Plate 9 


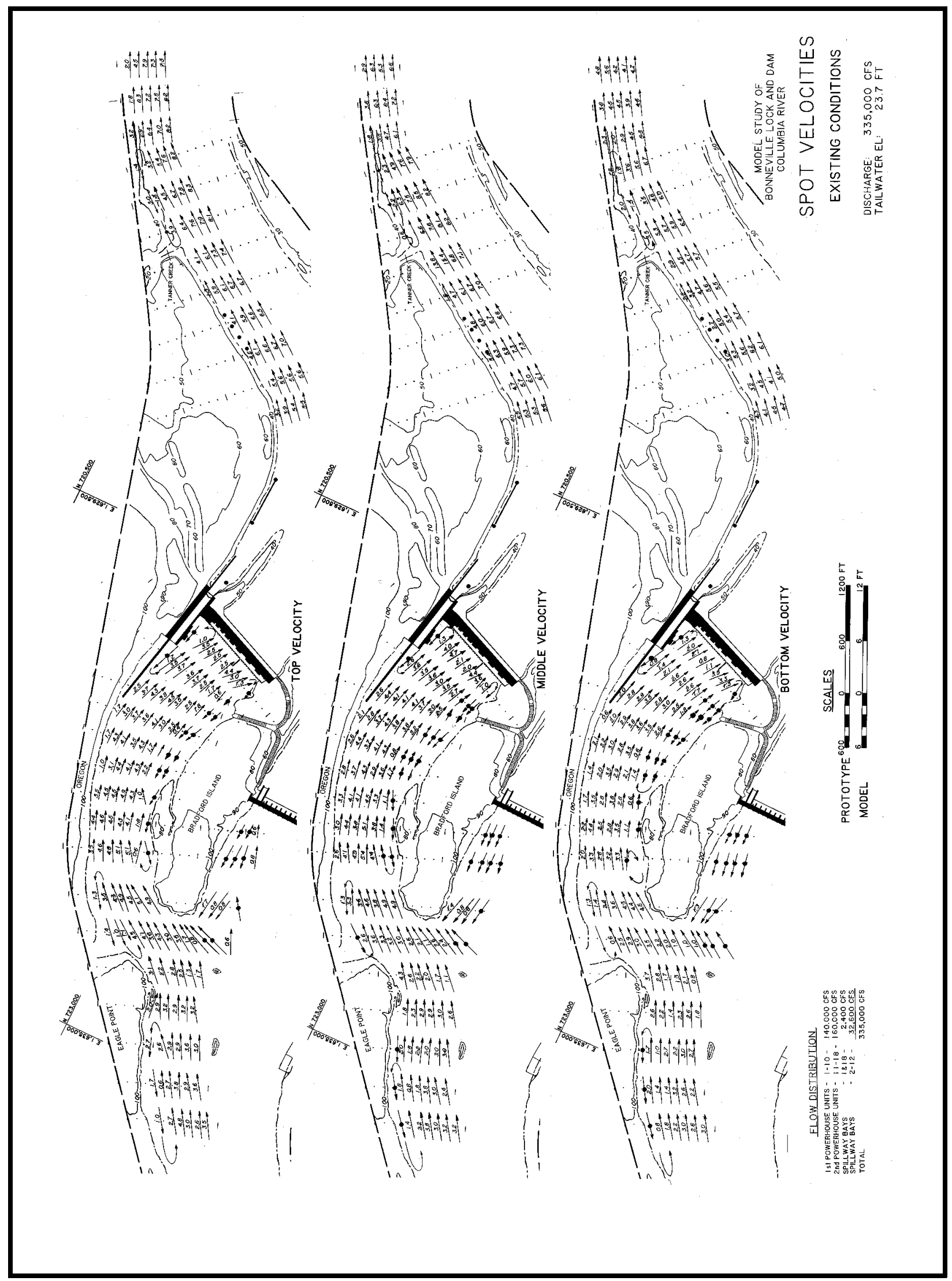

Plate 10 


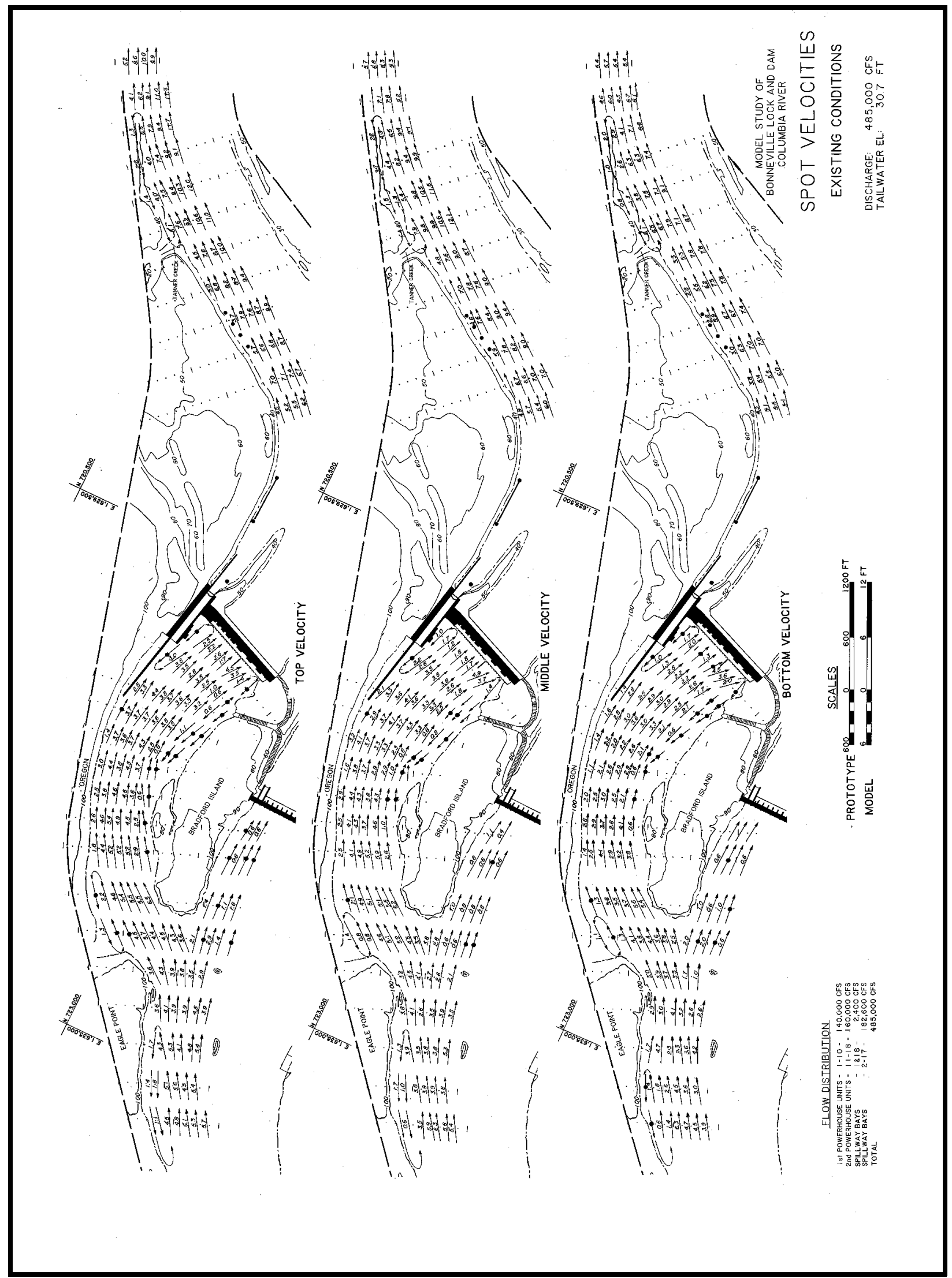

Plate 11 


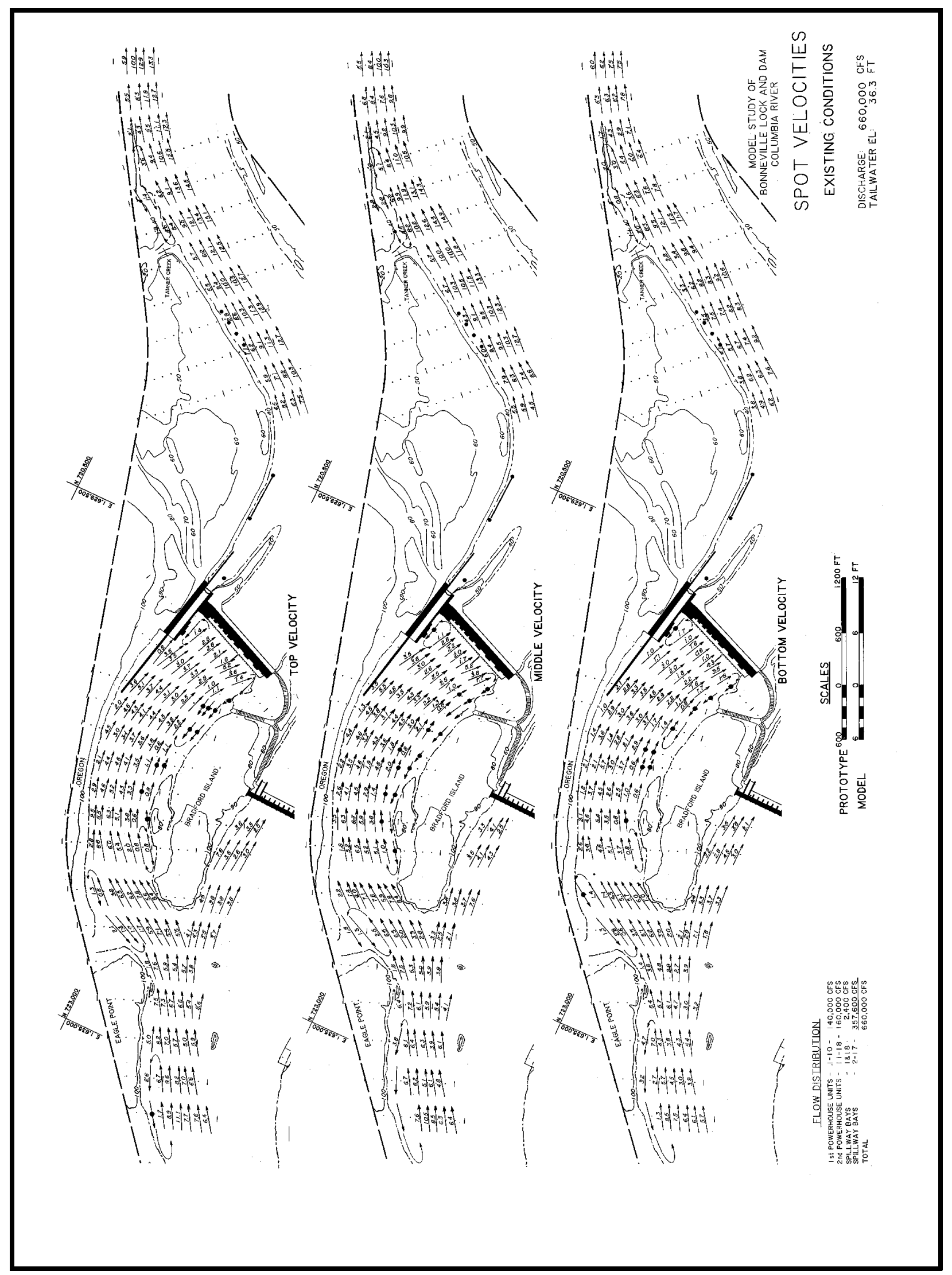

Plate 12 


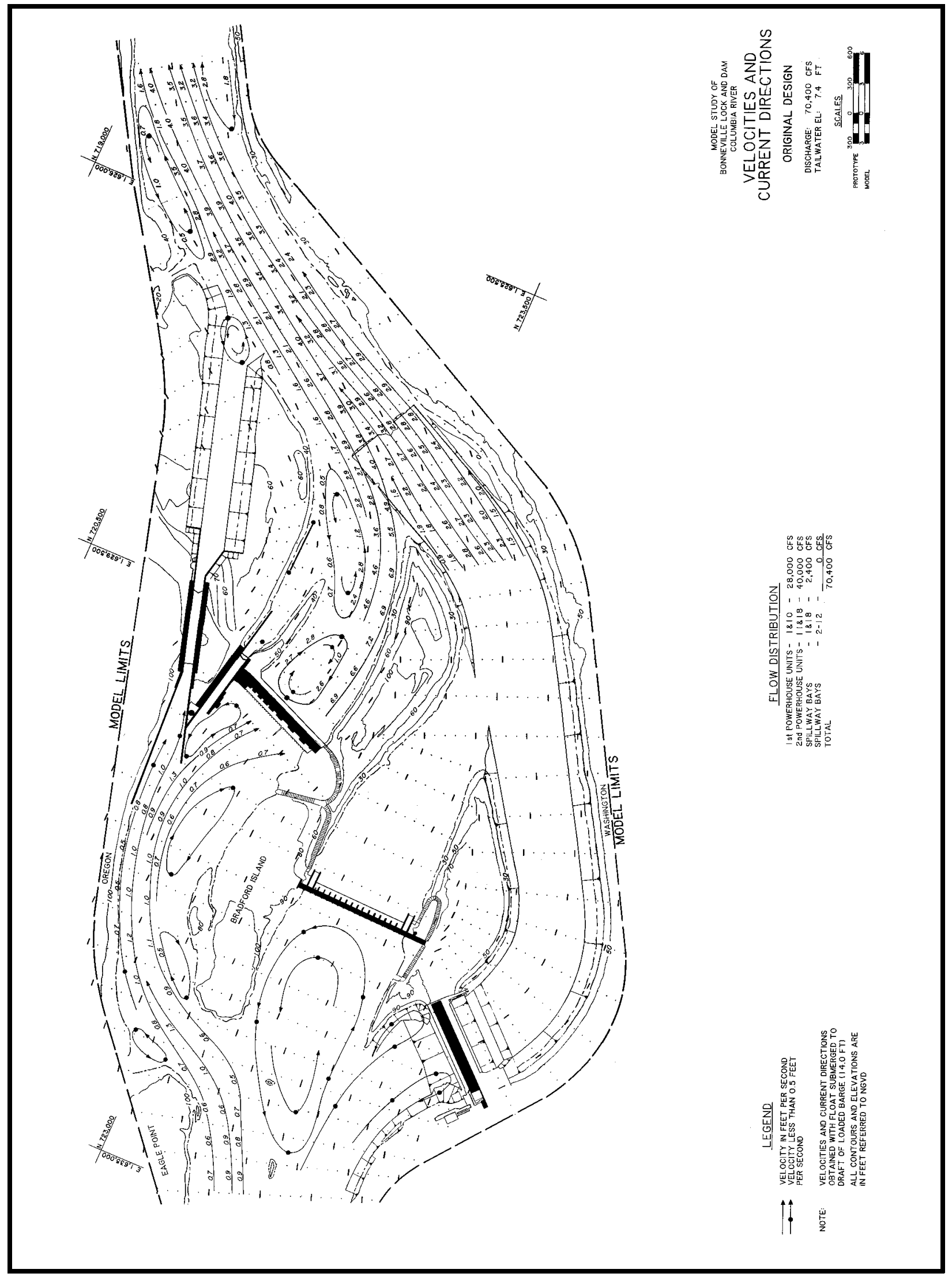

Plate 13 


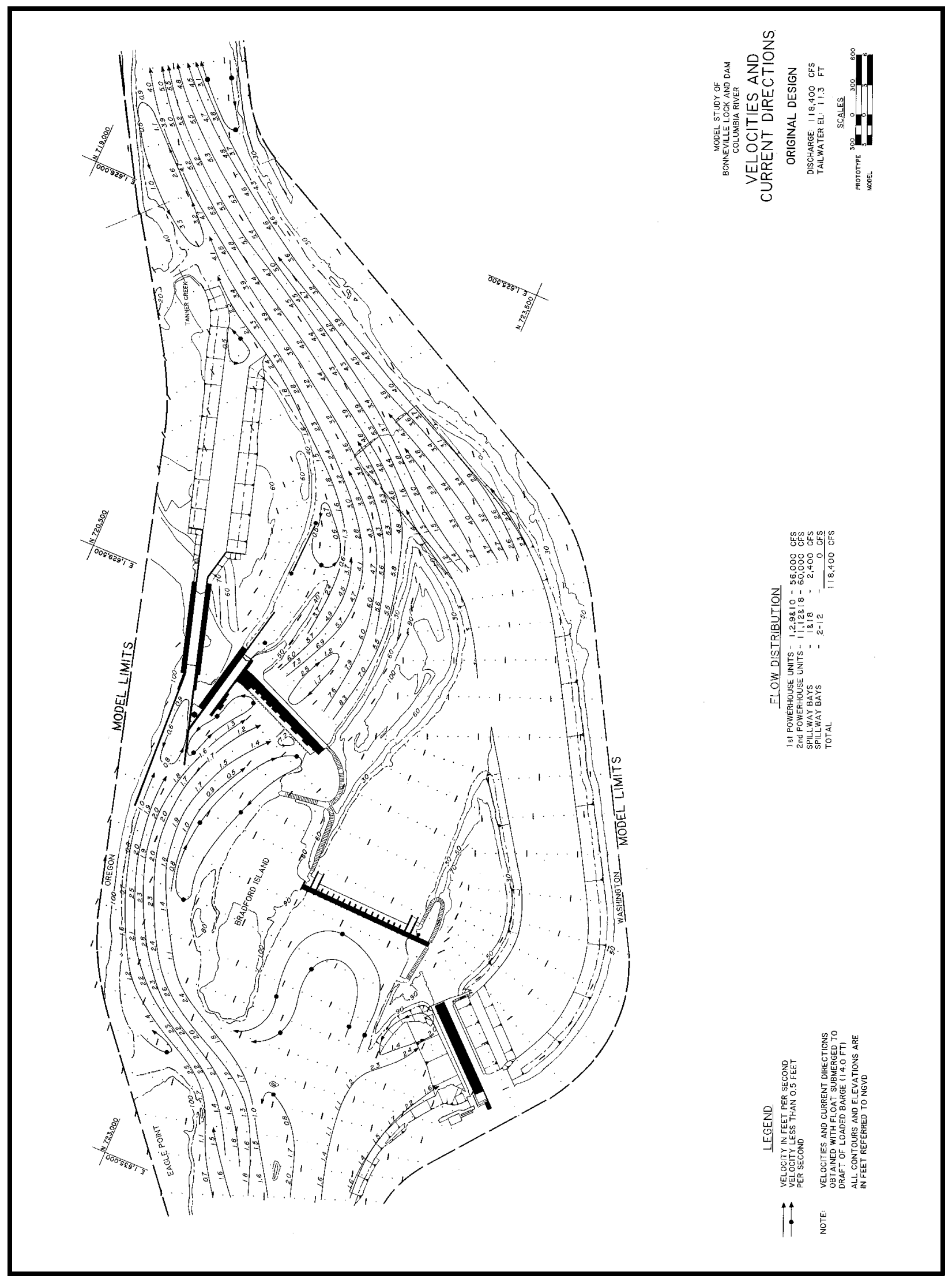

Plate 14 


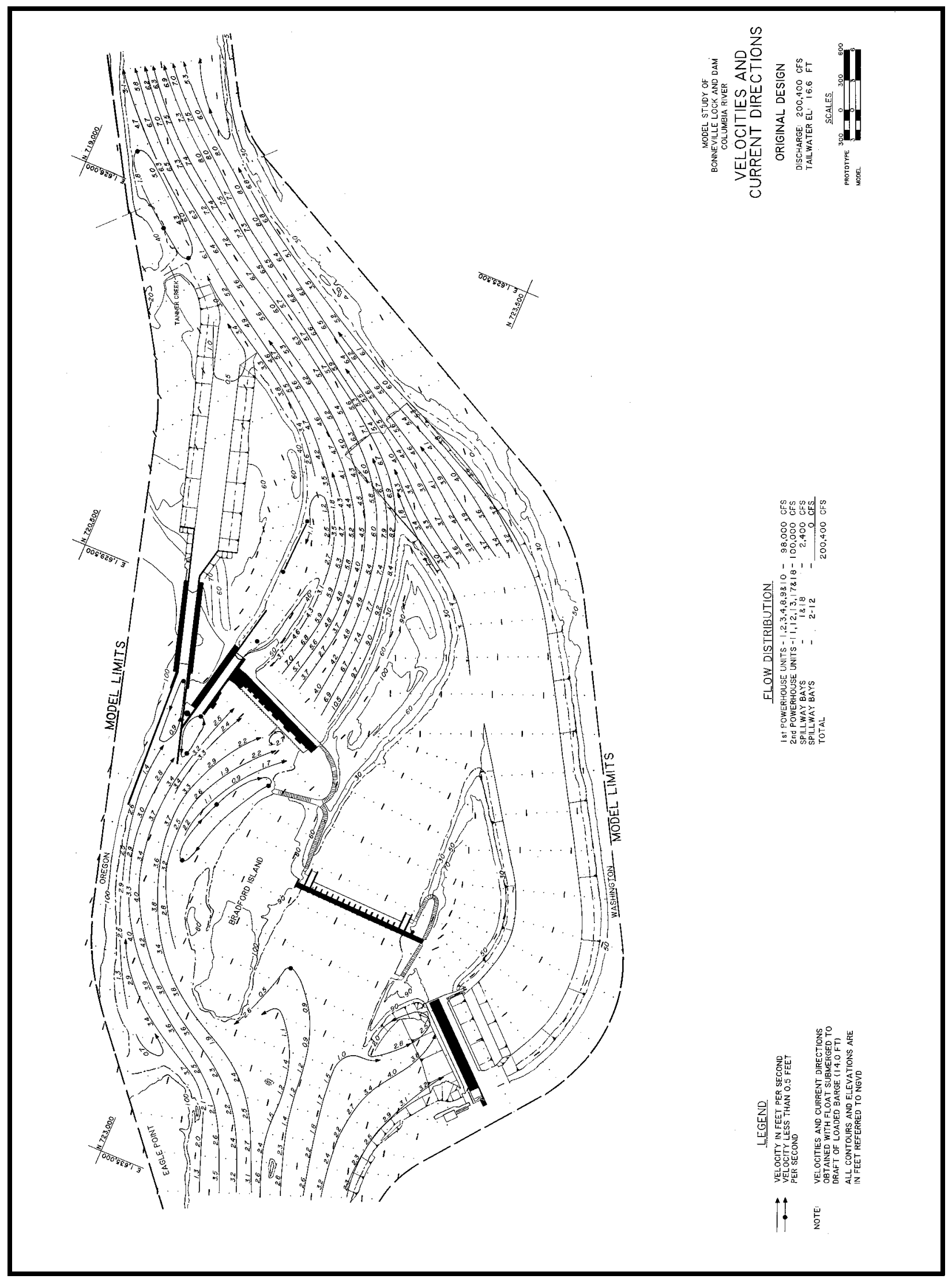

Plate 15 


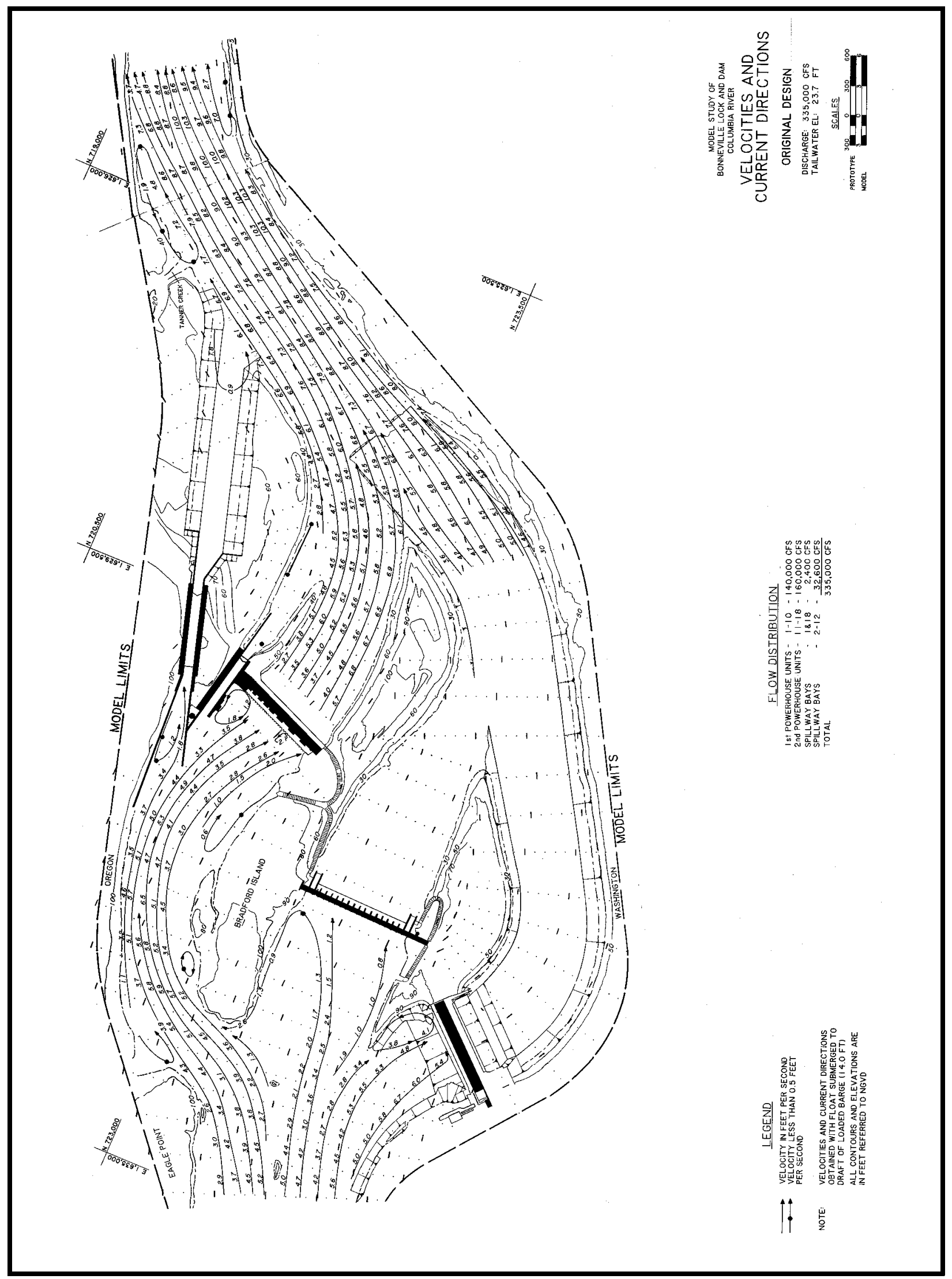

Plate 16 


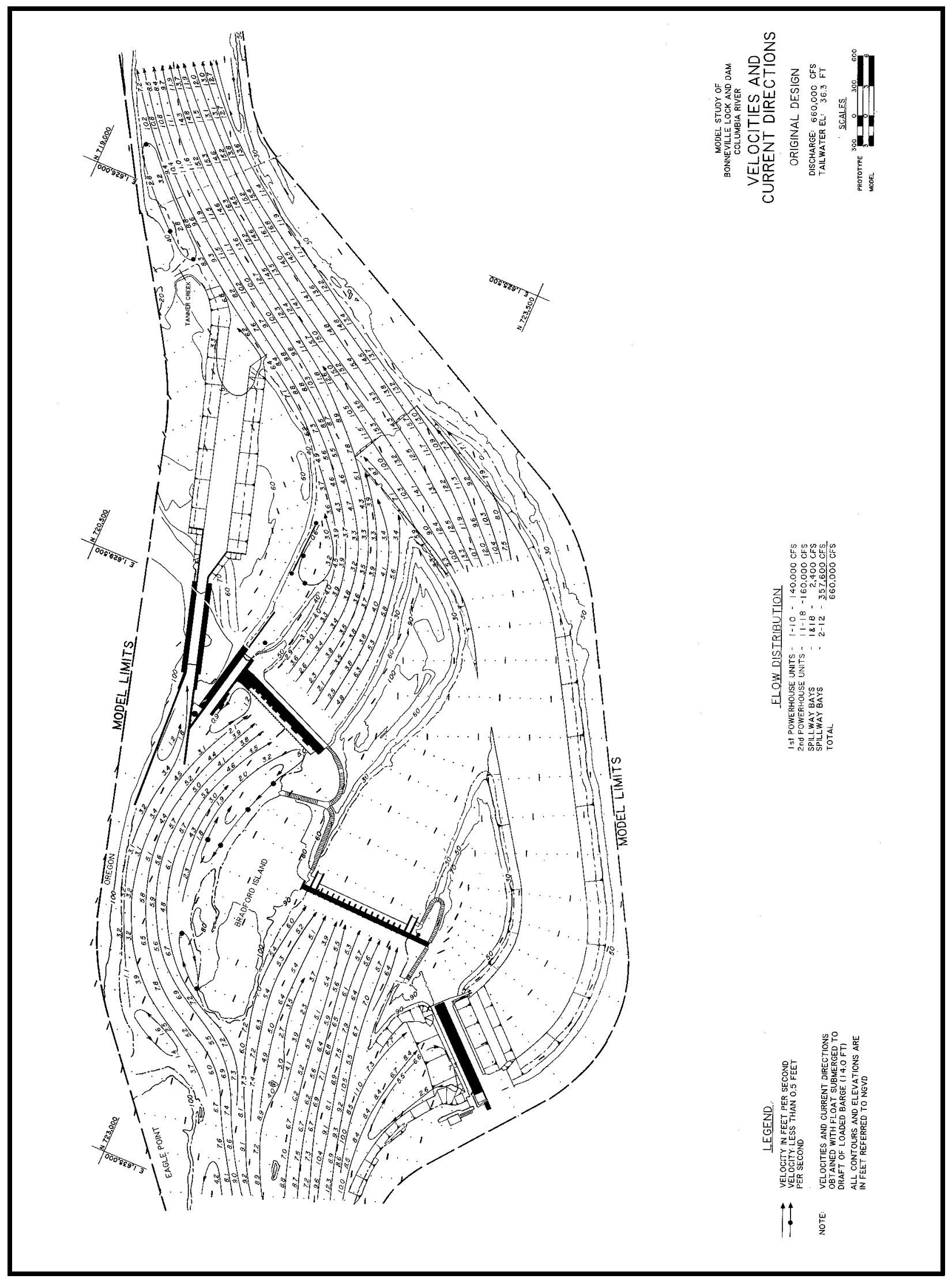

Plate 17 


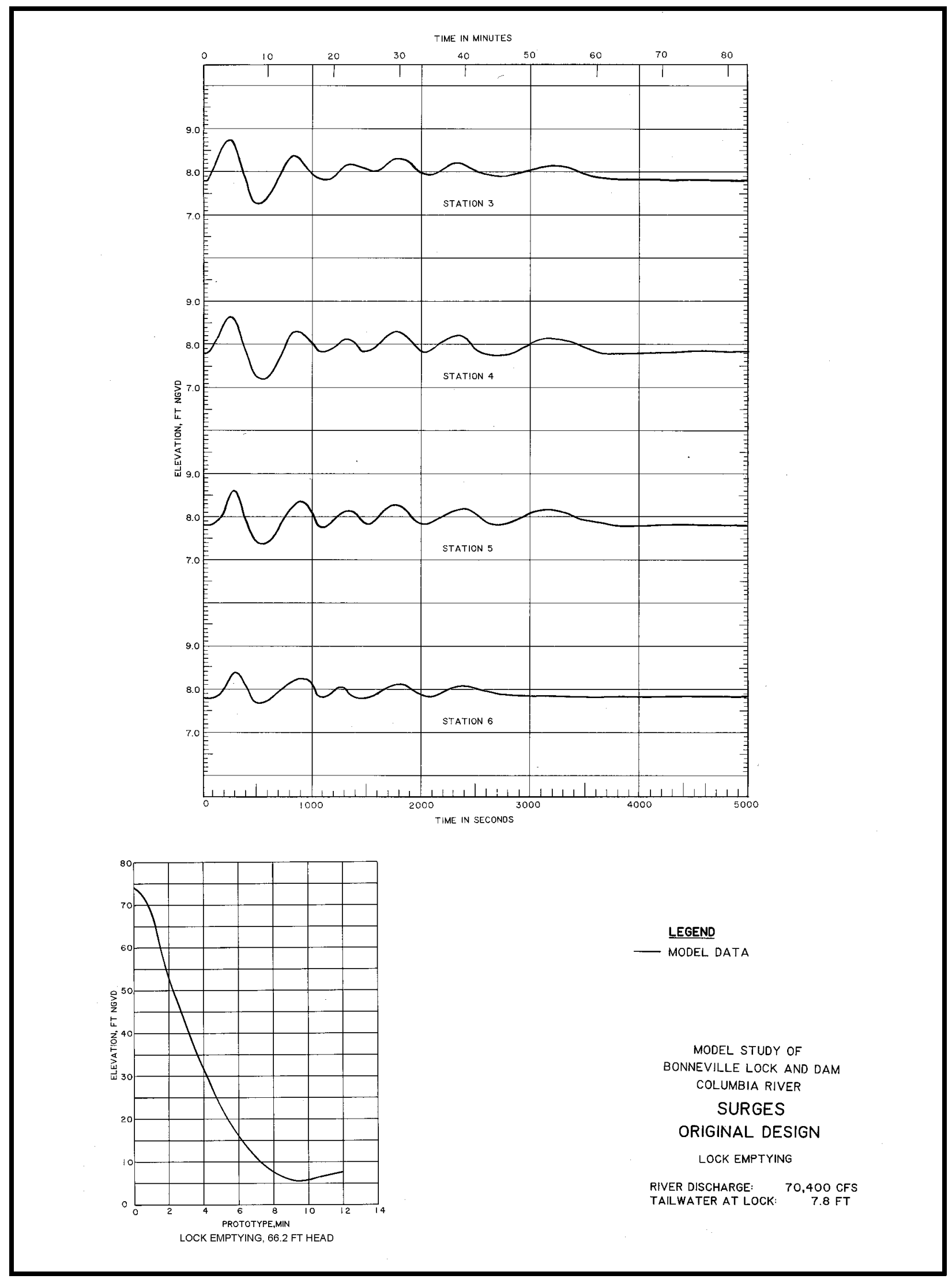

Plate 18 


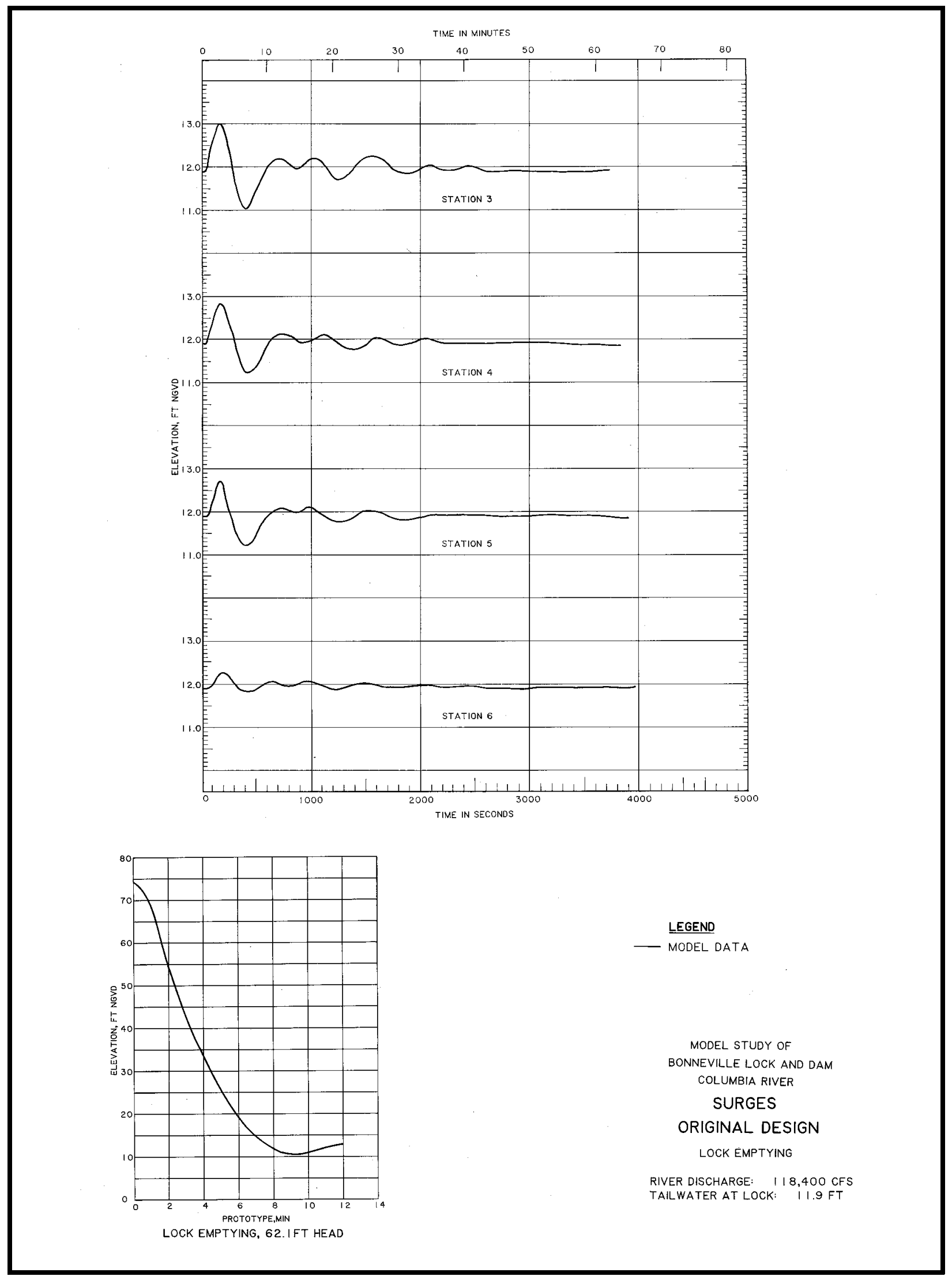

Plate 19 


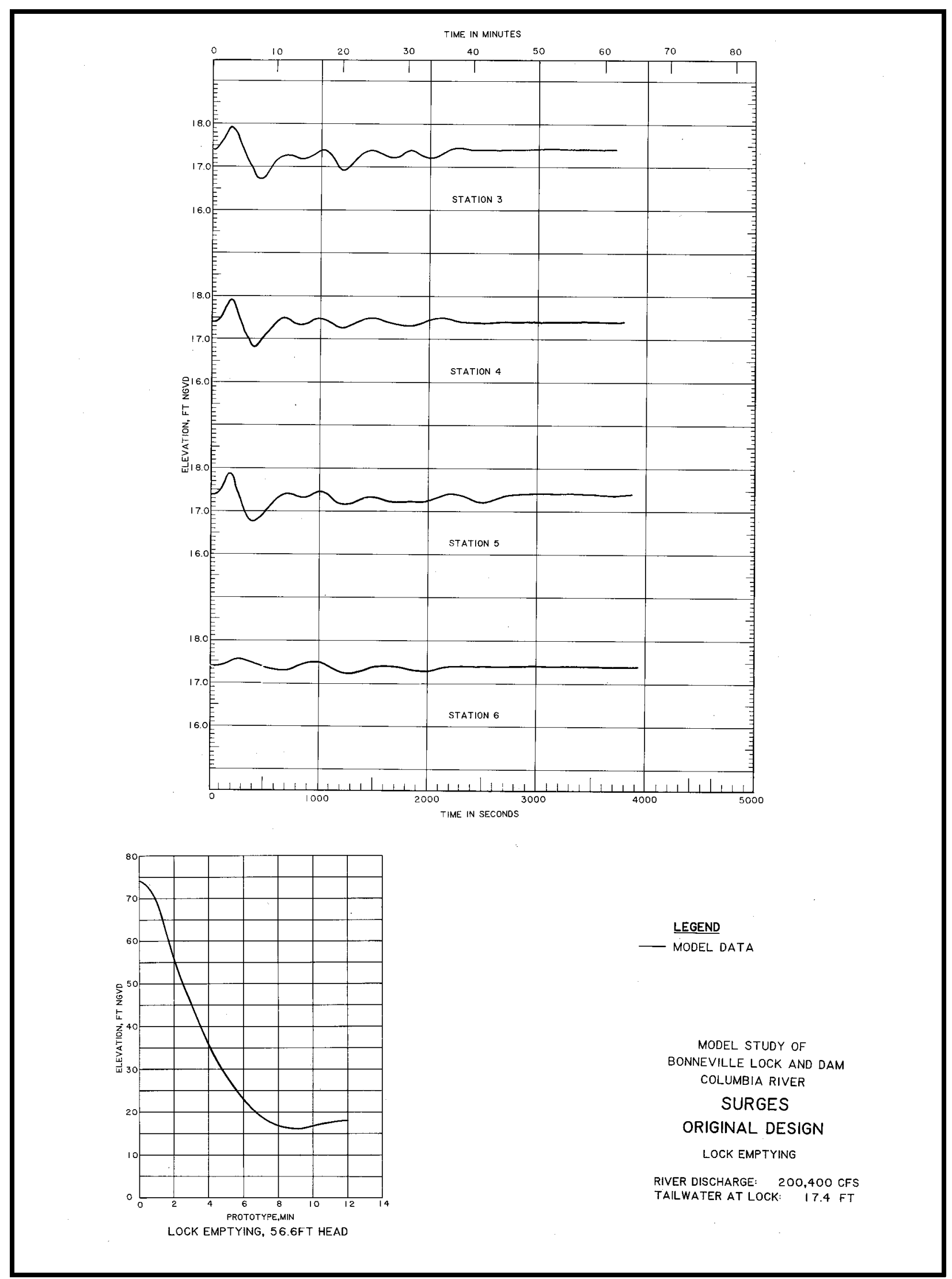

Plate 20 


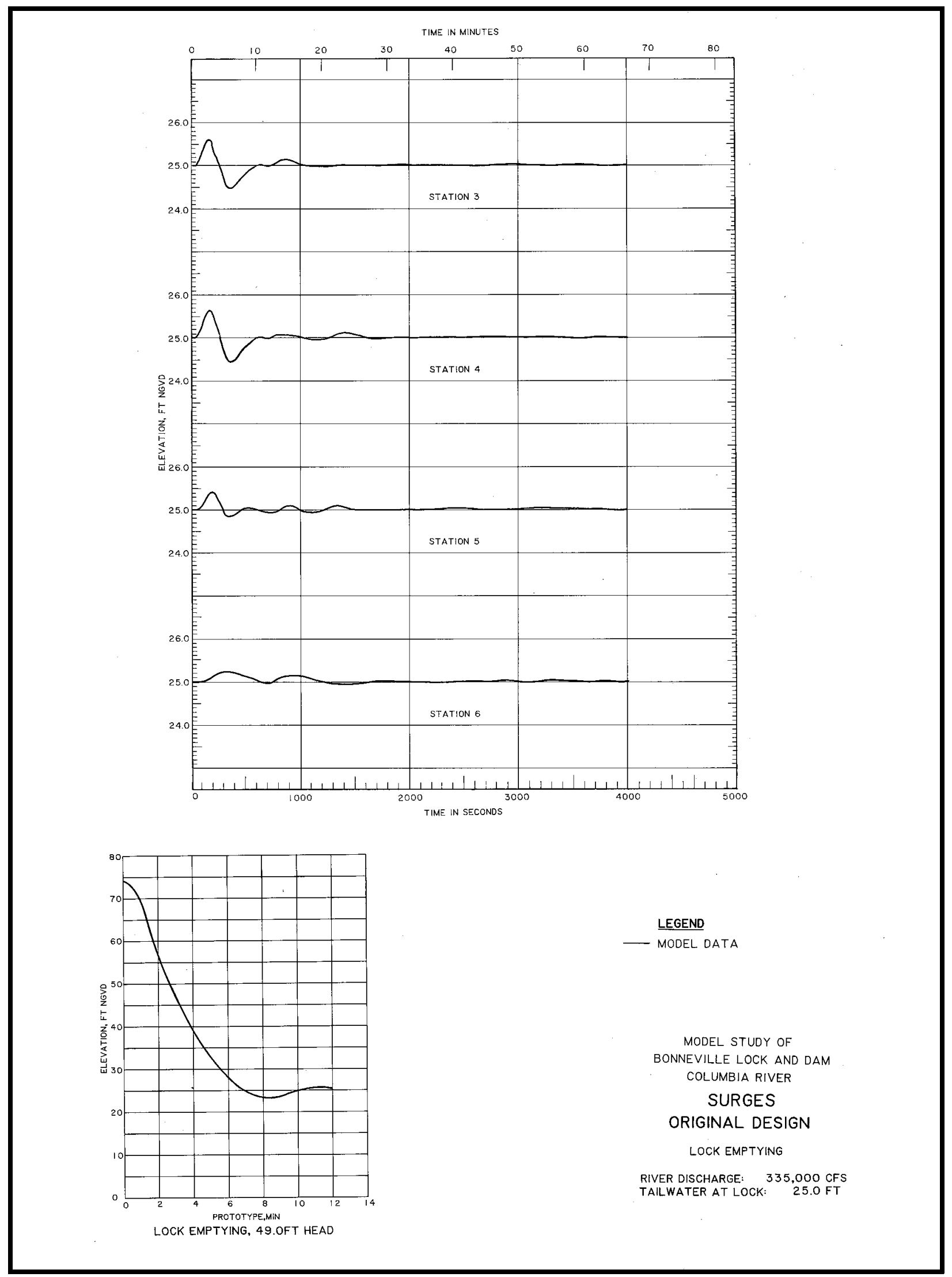

Plate 21 


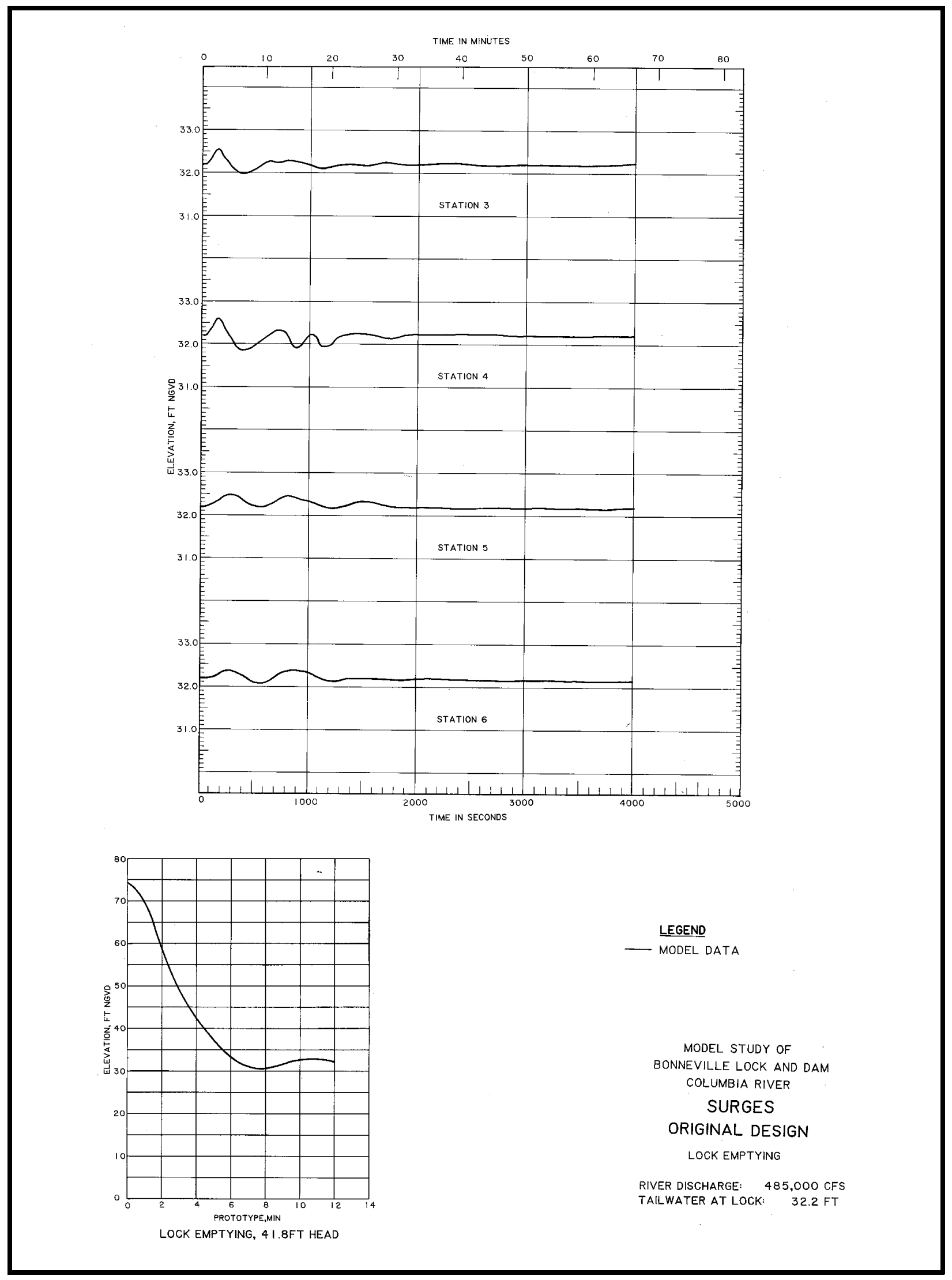

Plate 22 


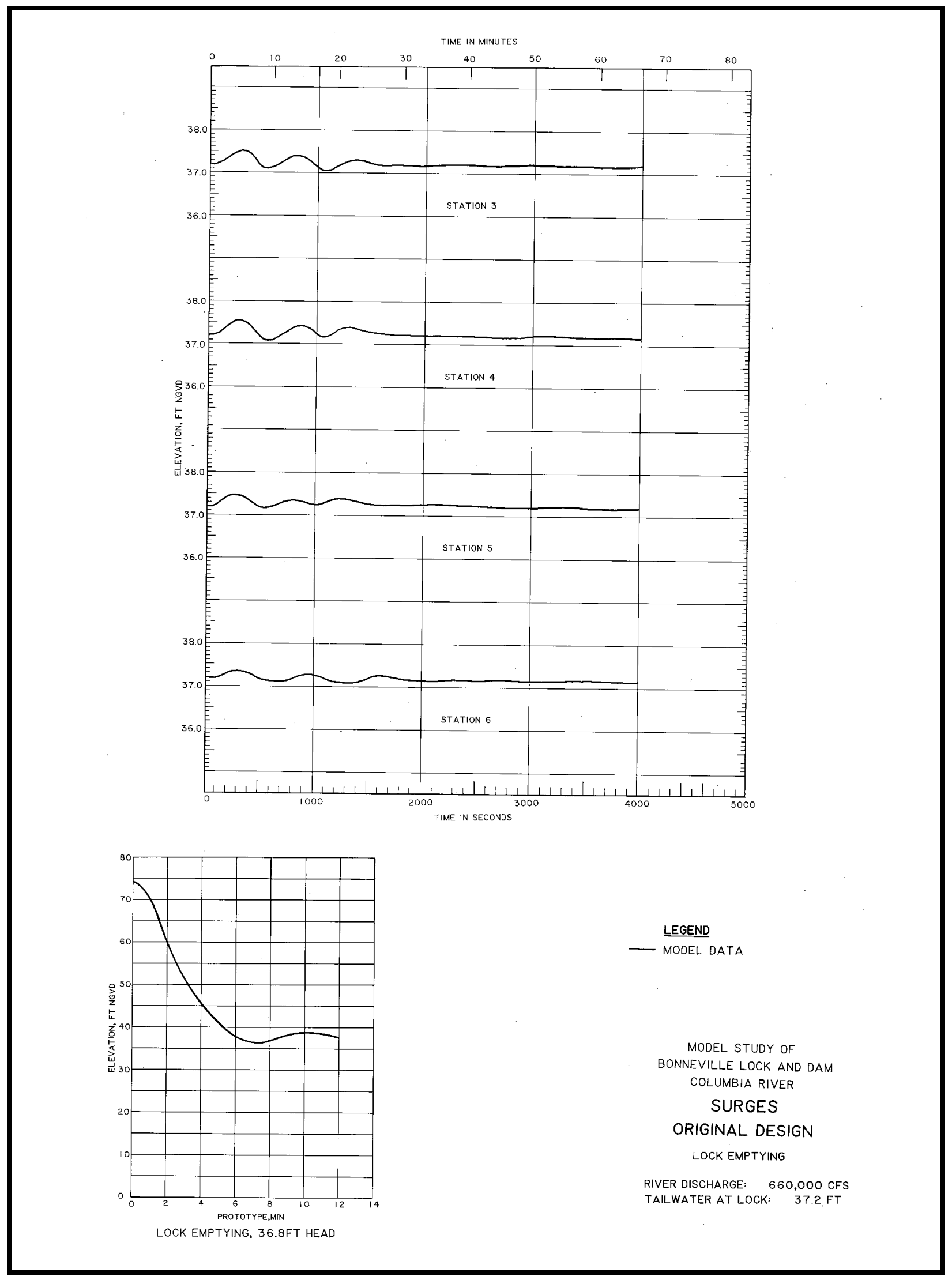

Plate 23 

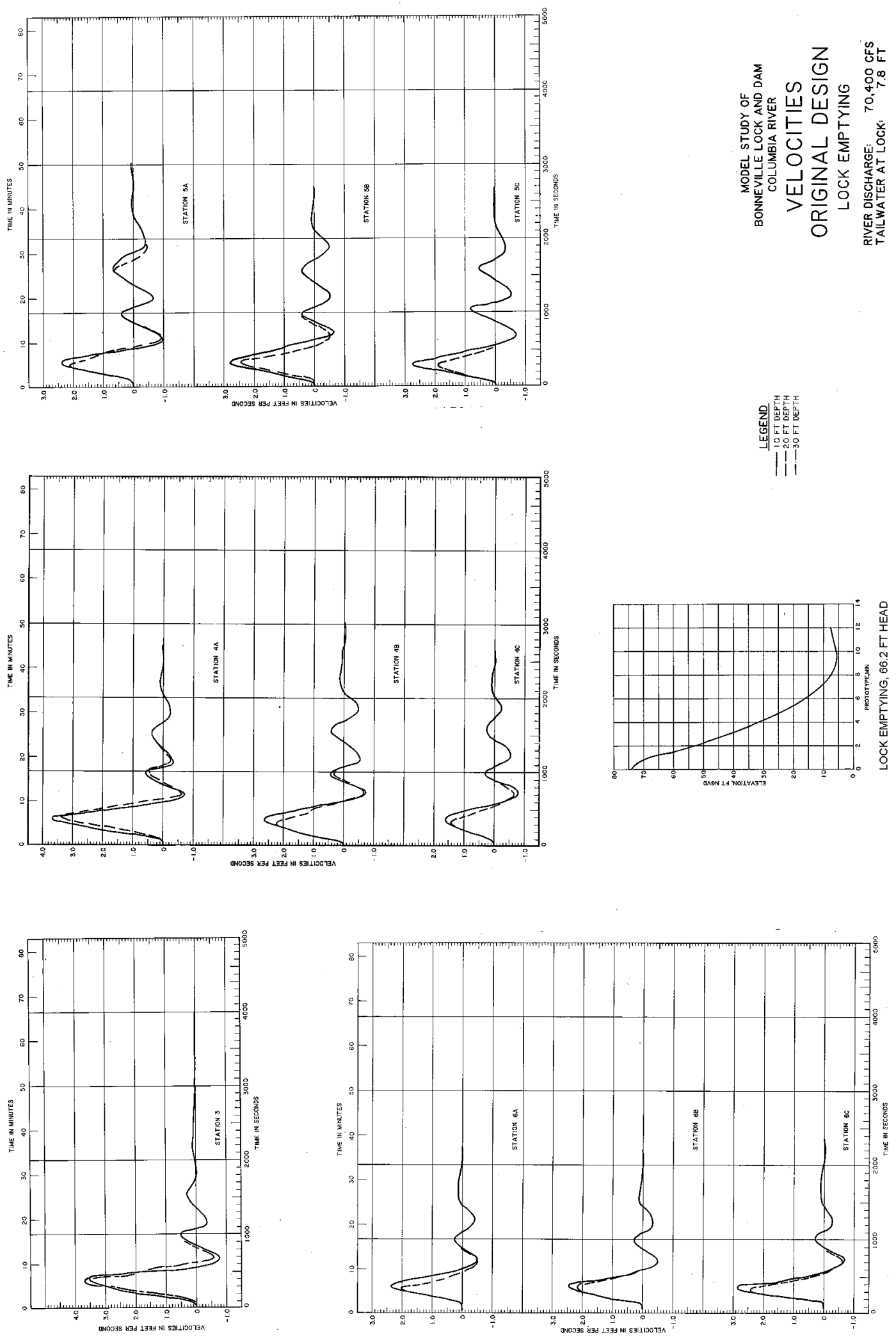

Plate 24 

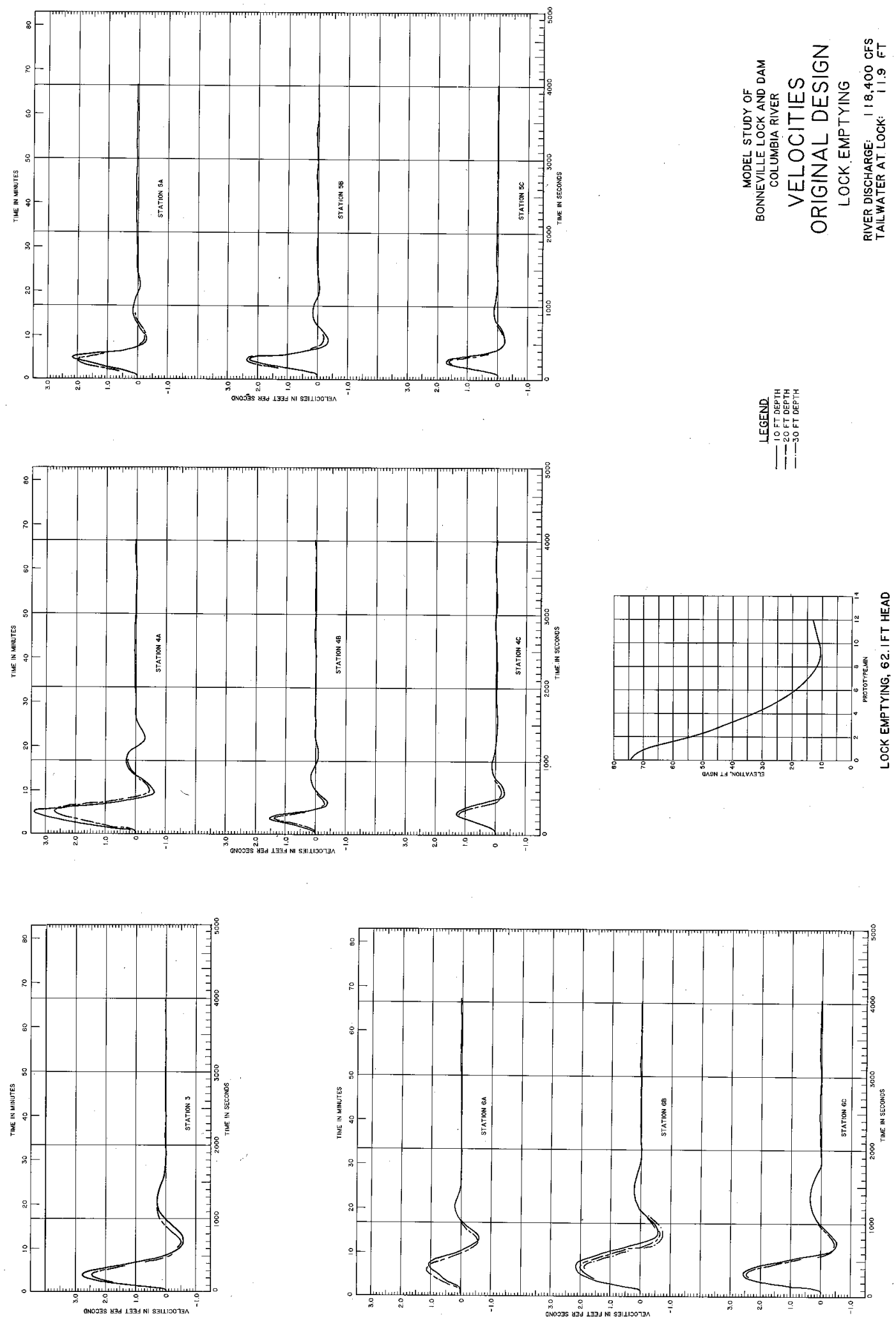

Plate 25 

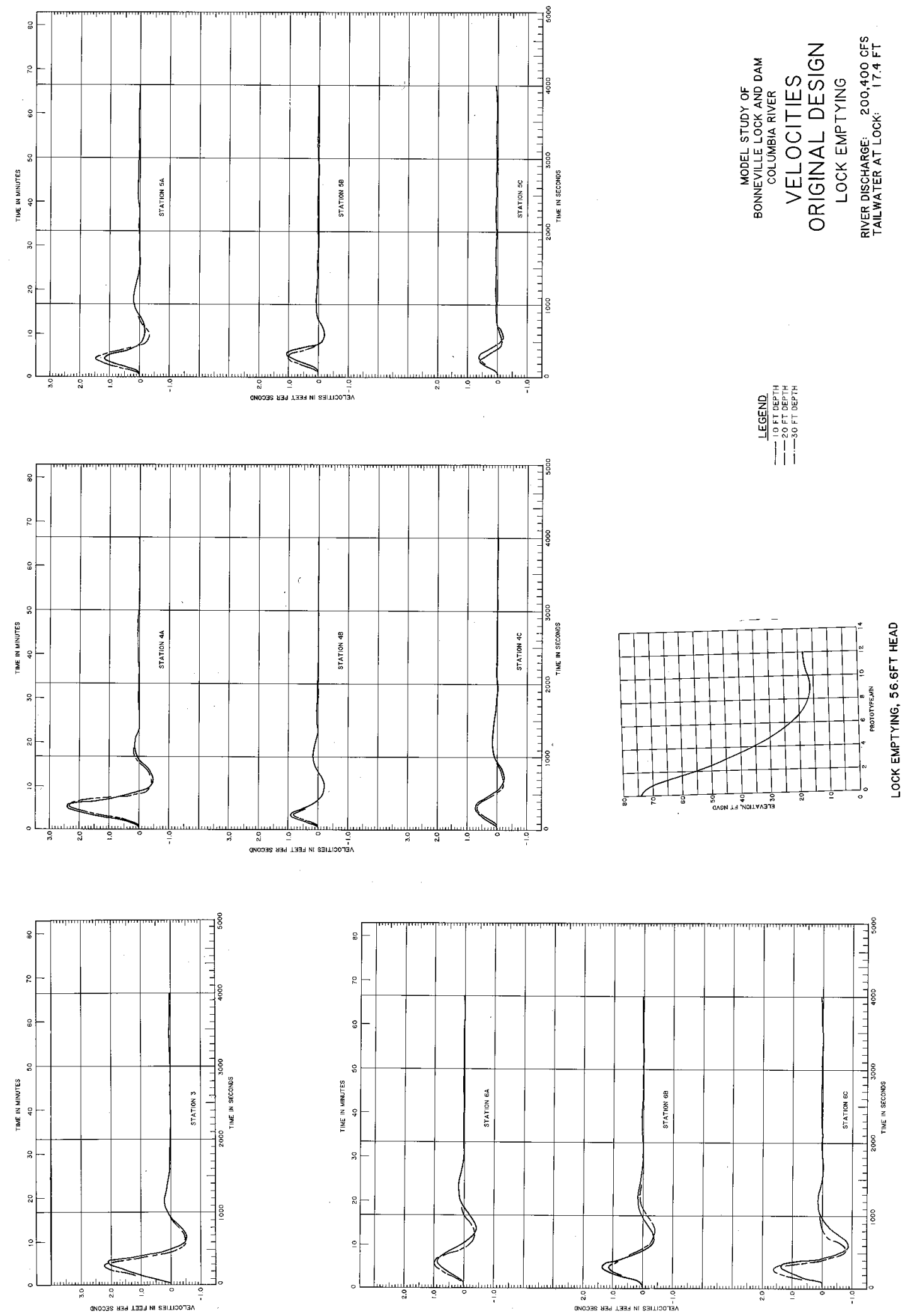

Plate 26 


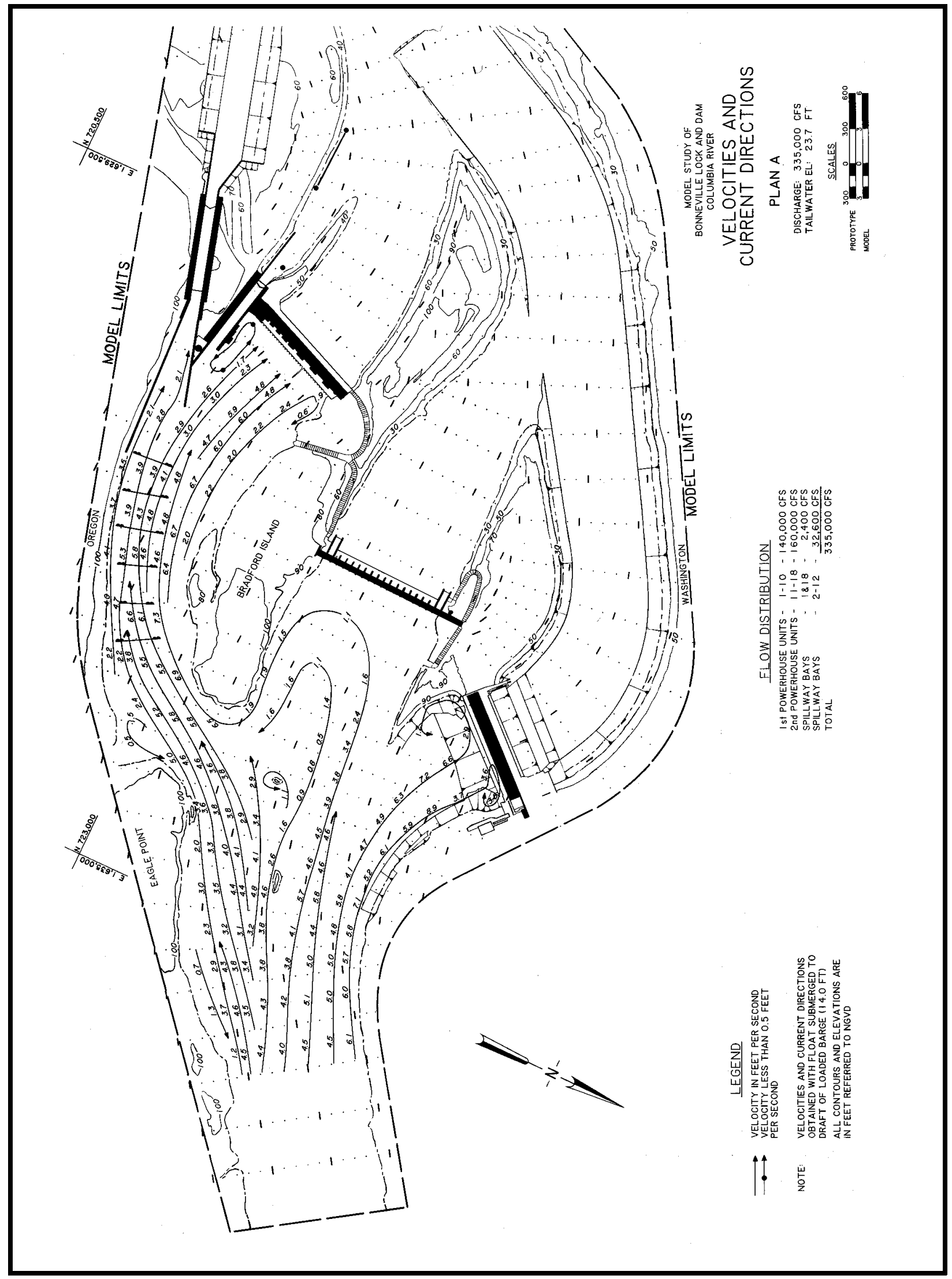

Plate 27 


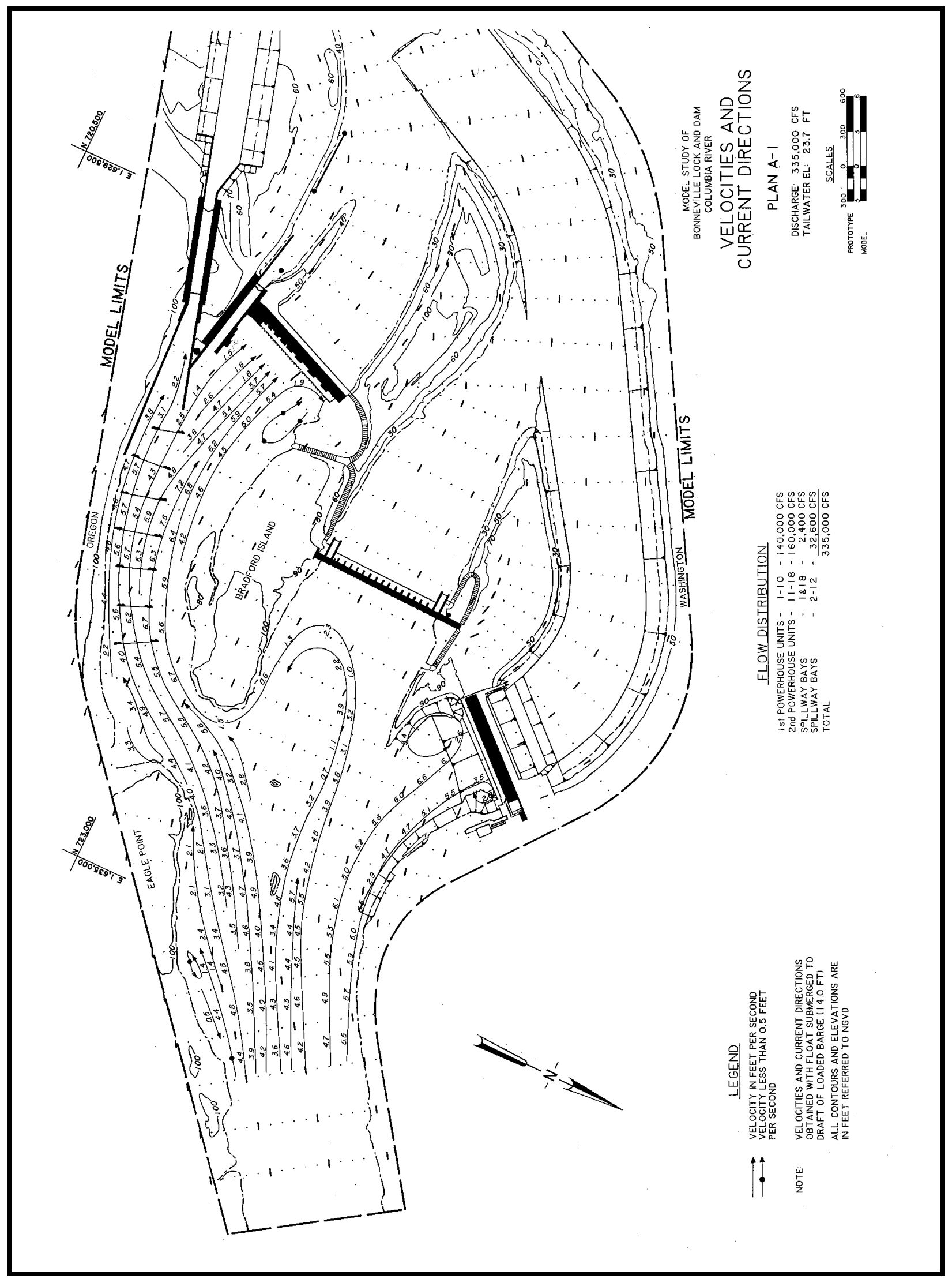

Plate 28 


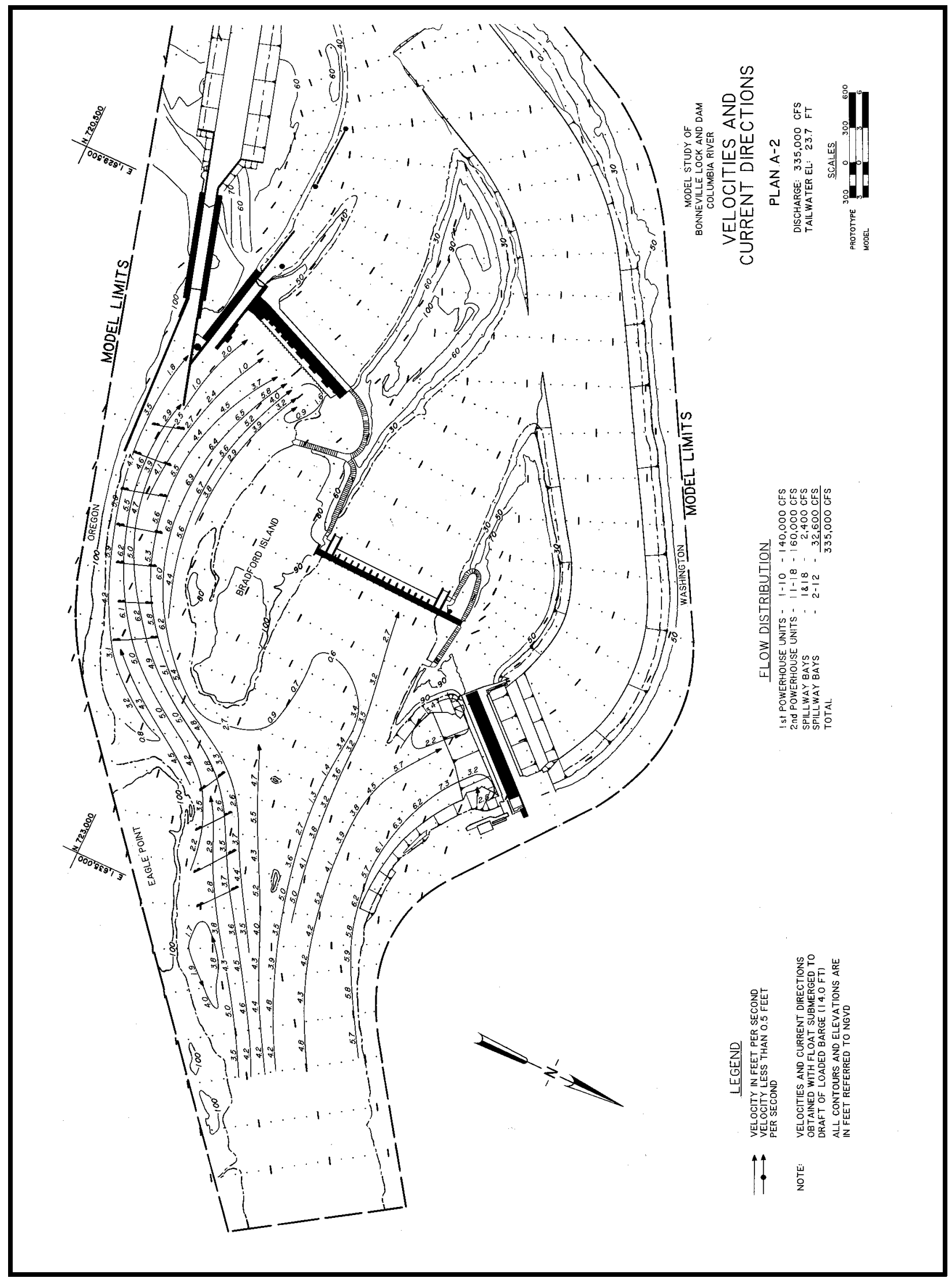

Plate 29 


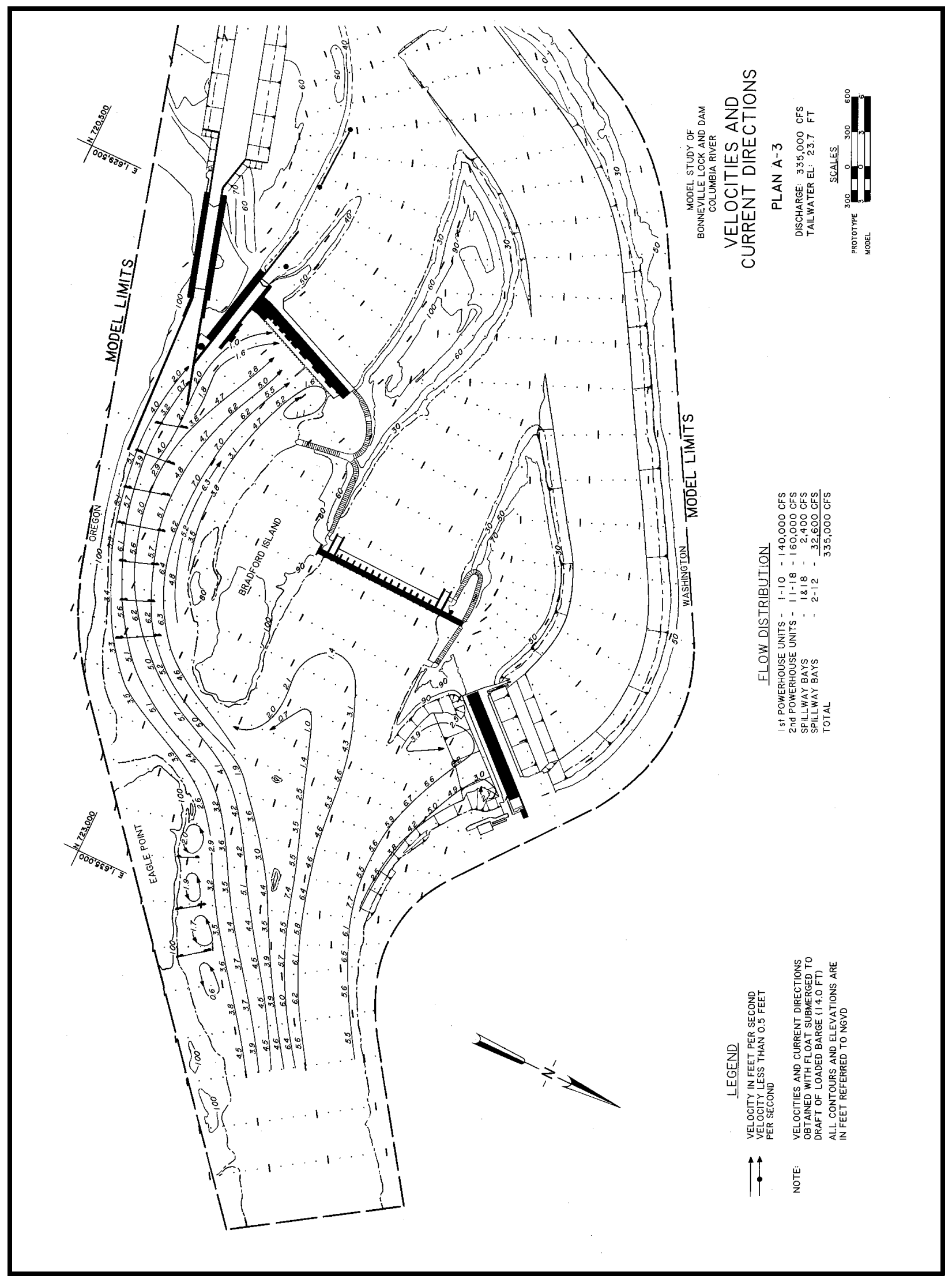

Plate 30 


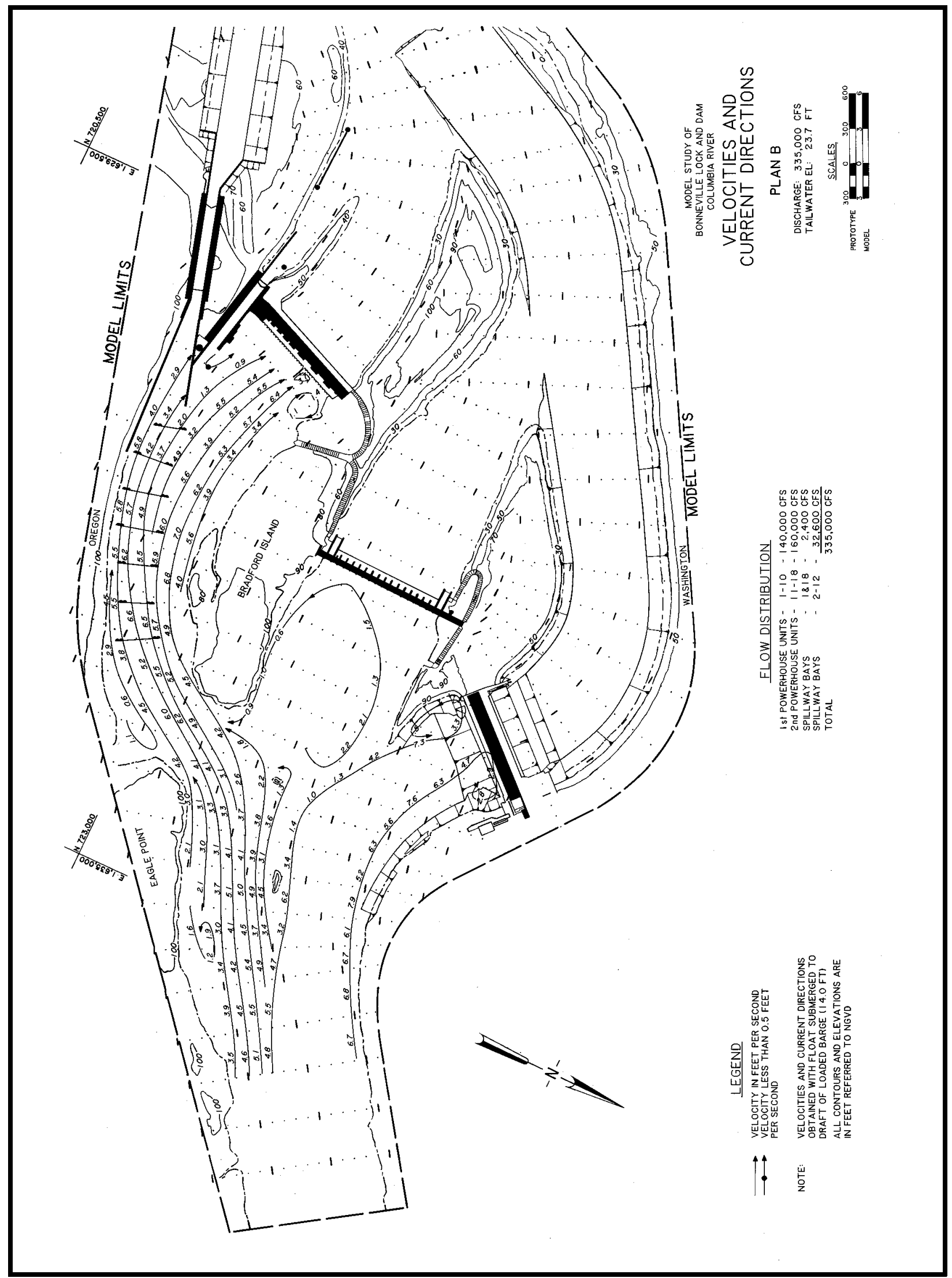

Plate 31 


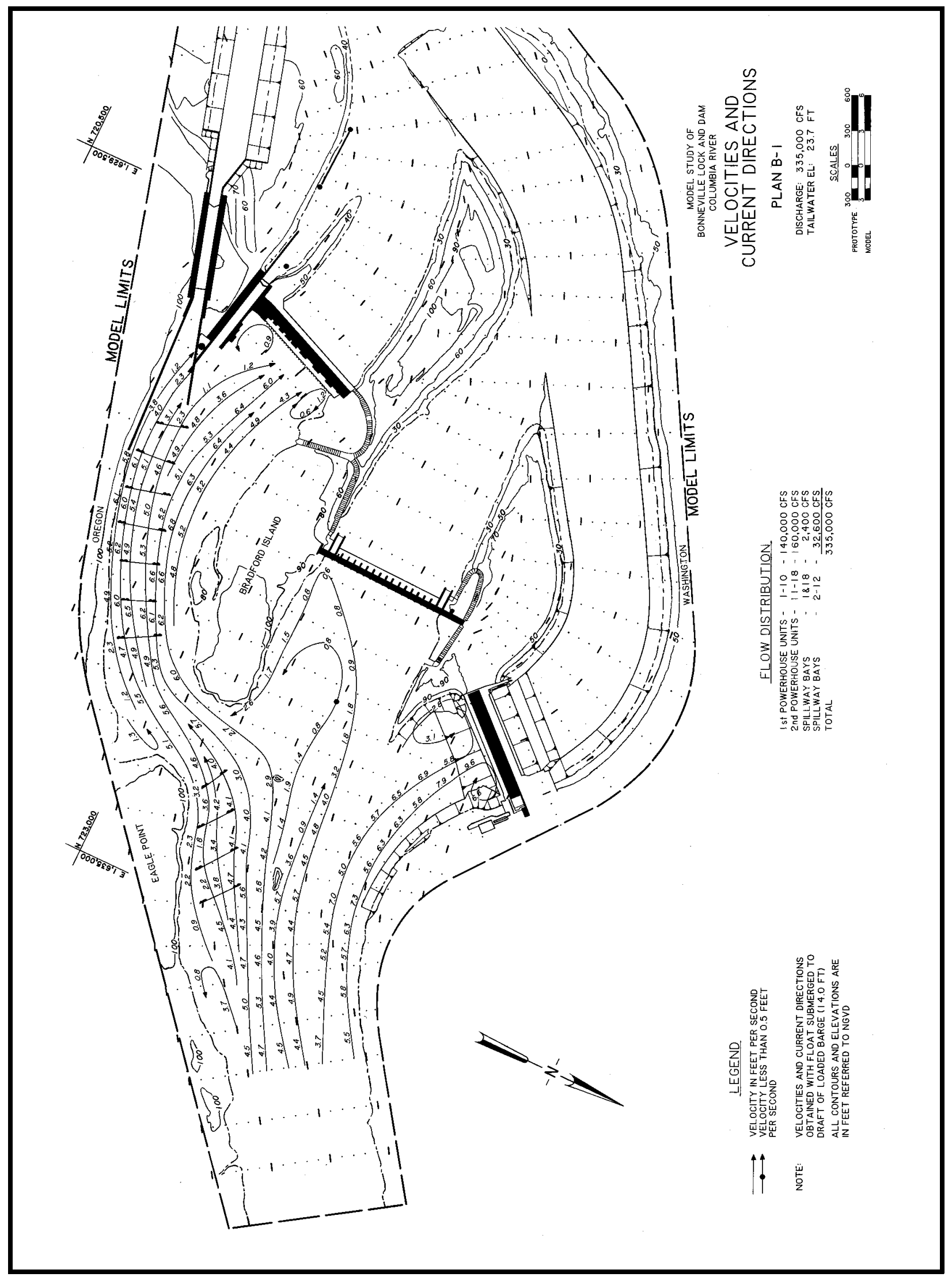

Plate 32 


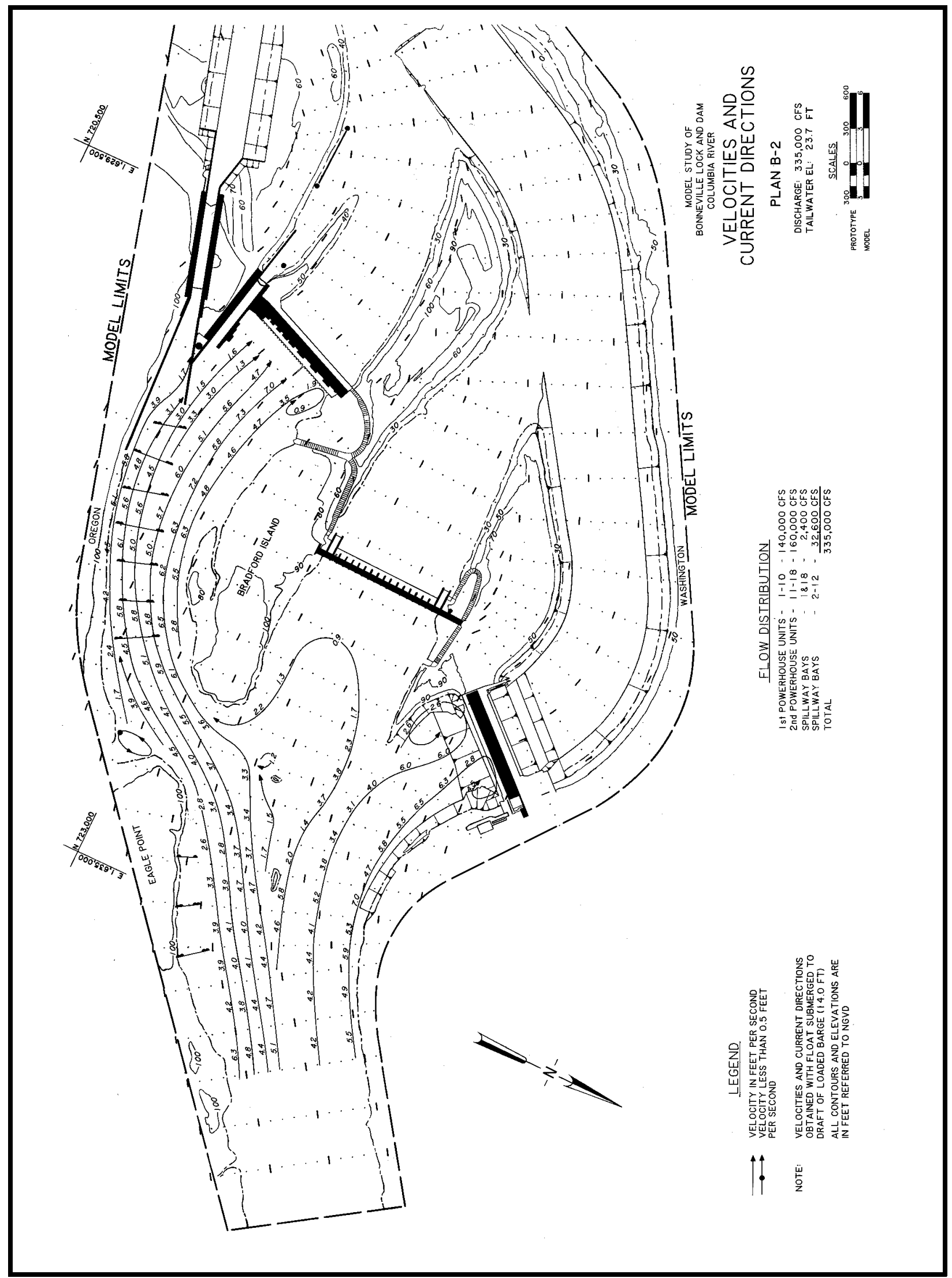

Plate 33 


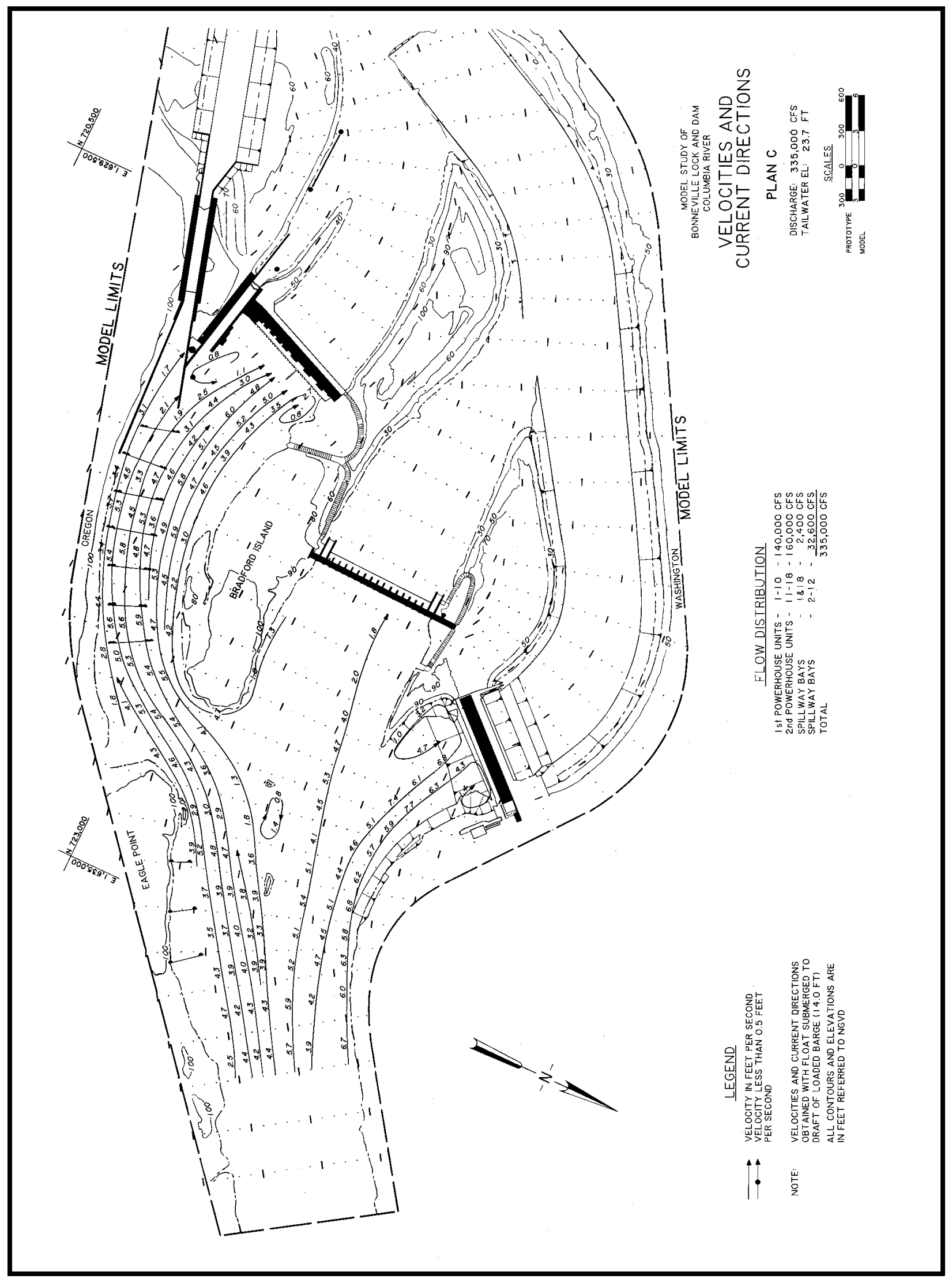

Plate 34 


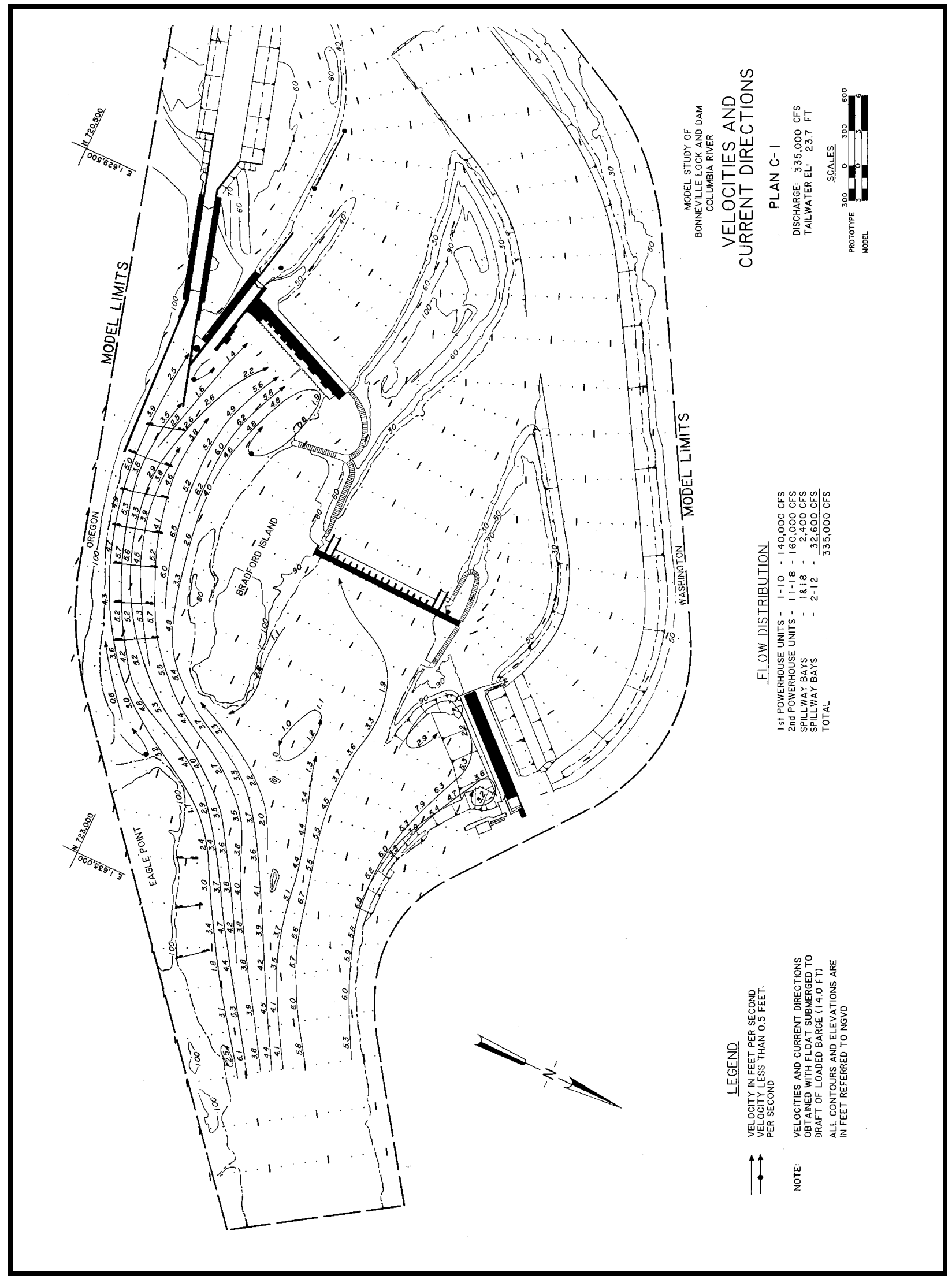

Plate 35 


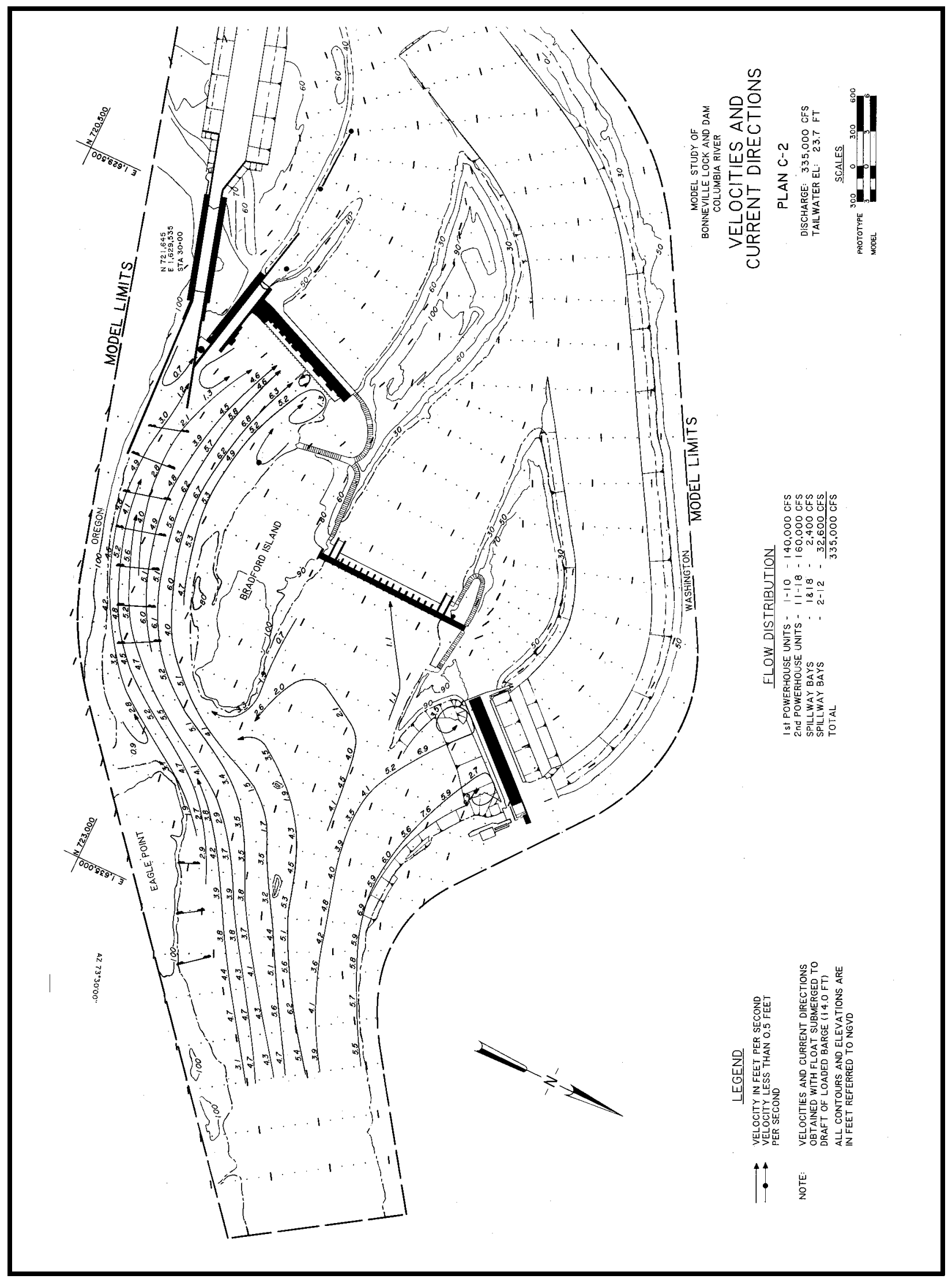

Plate 36 


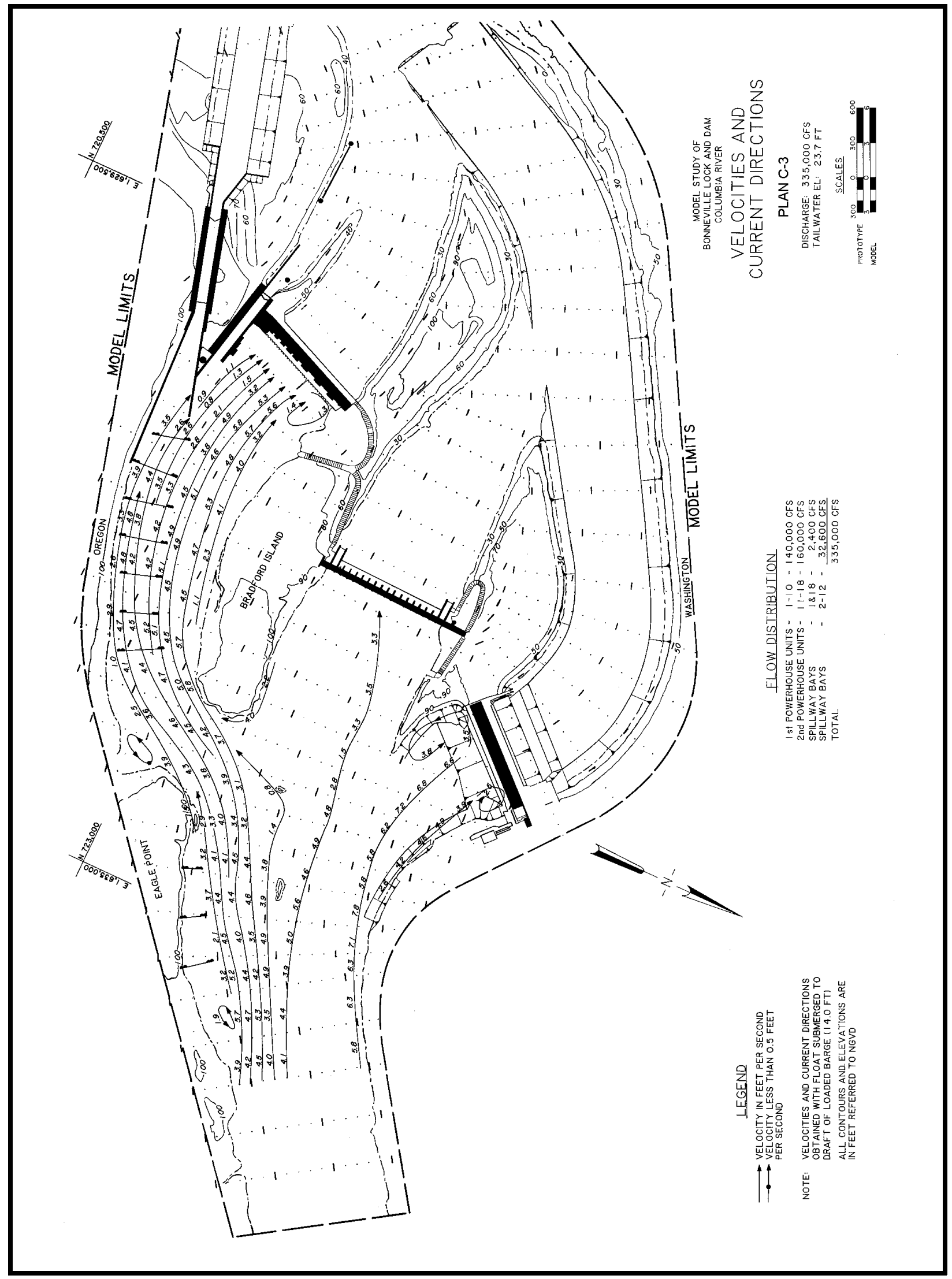

Plate 37 


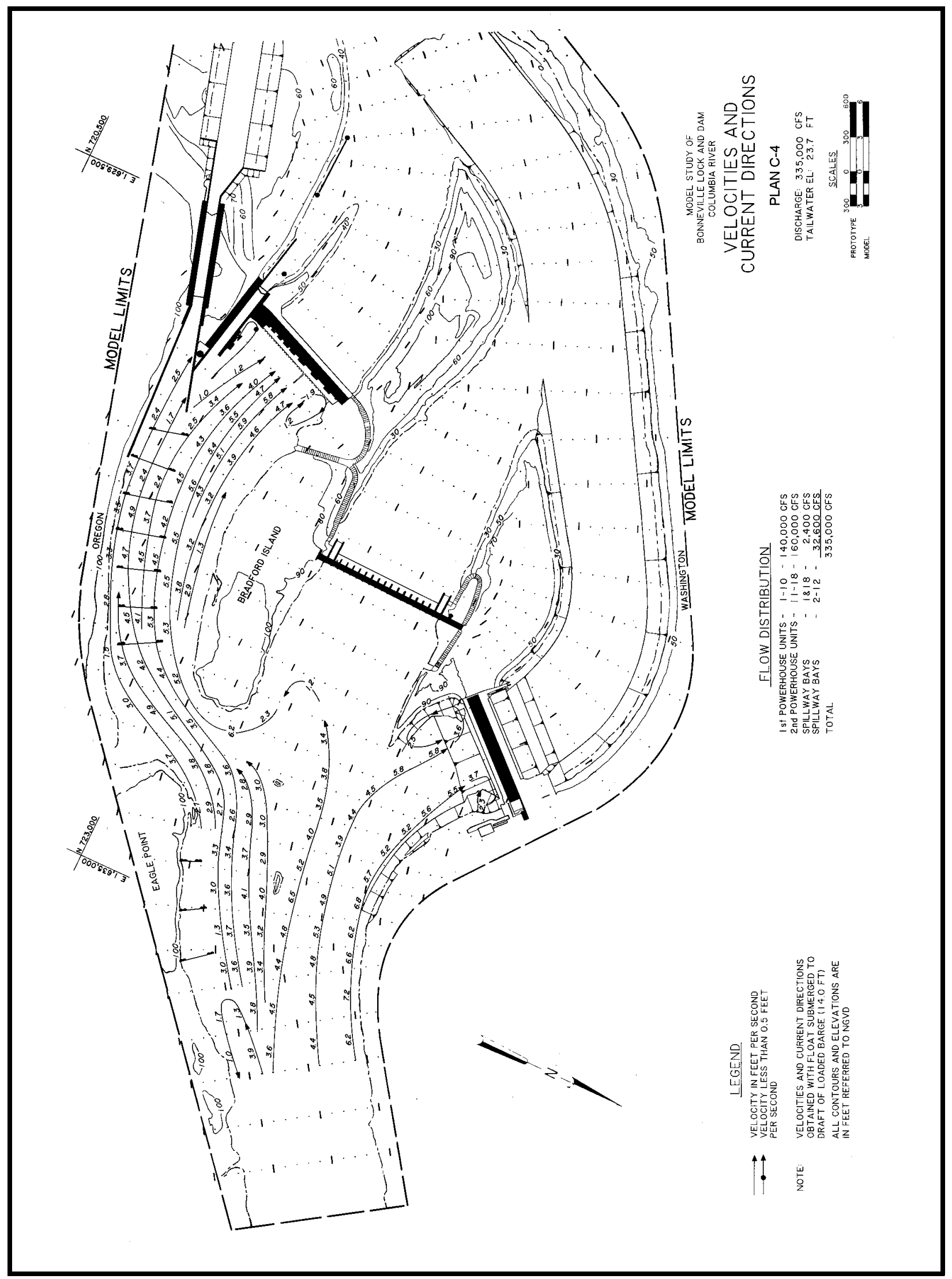

Plate 38 


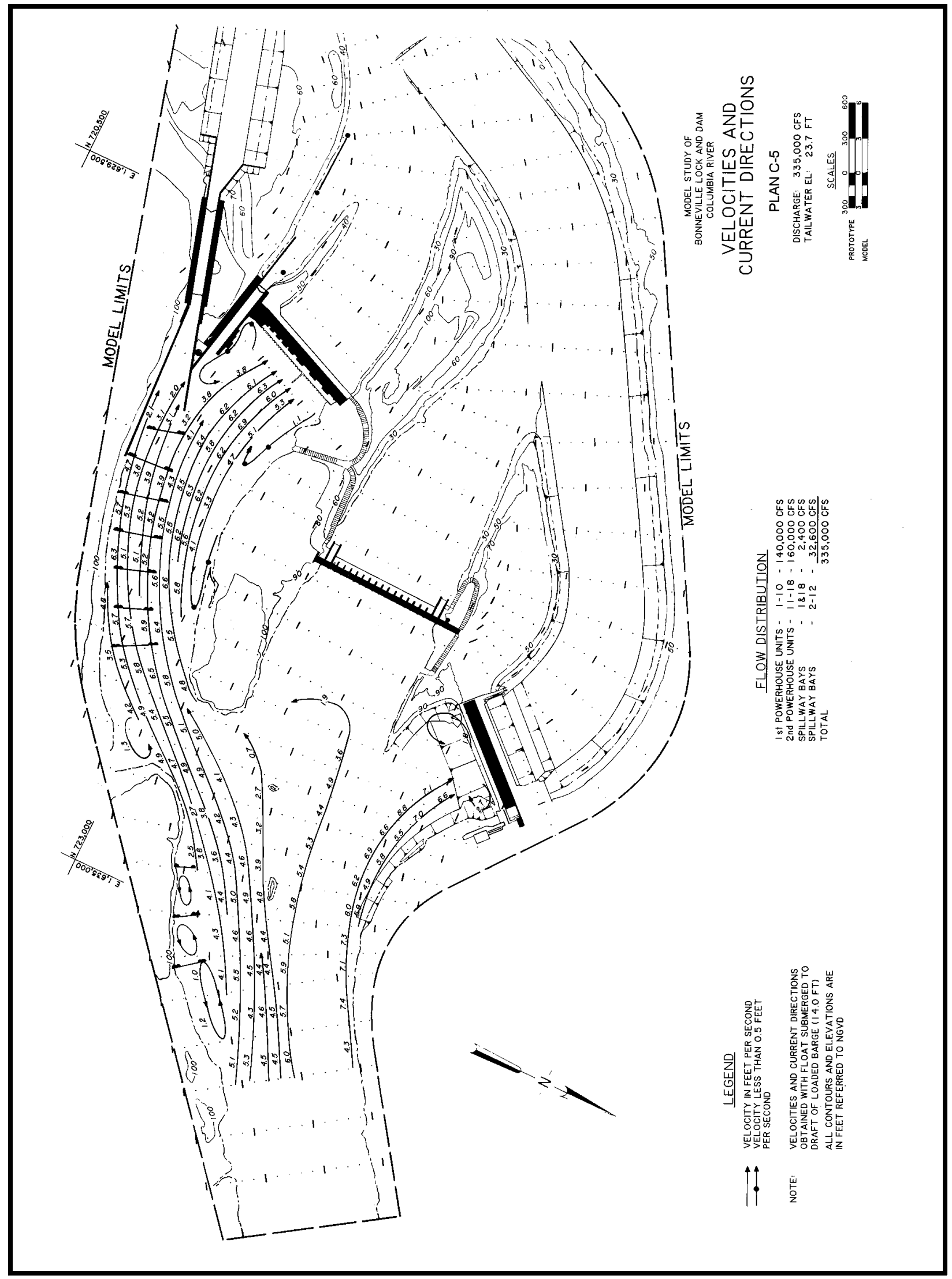

Plate 39 


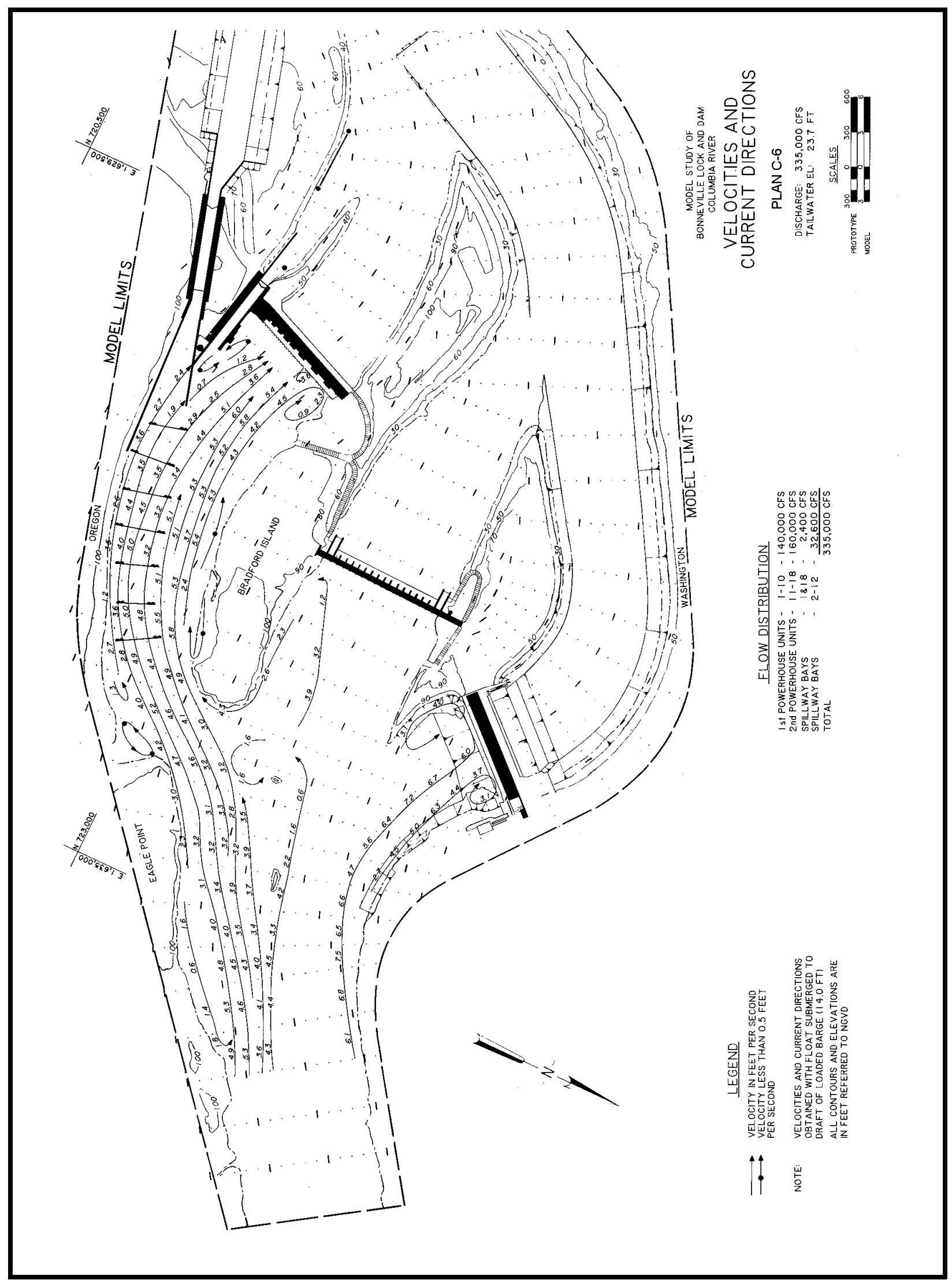

Plate $\mathbf{4 0}$ 


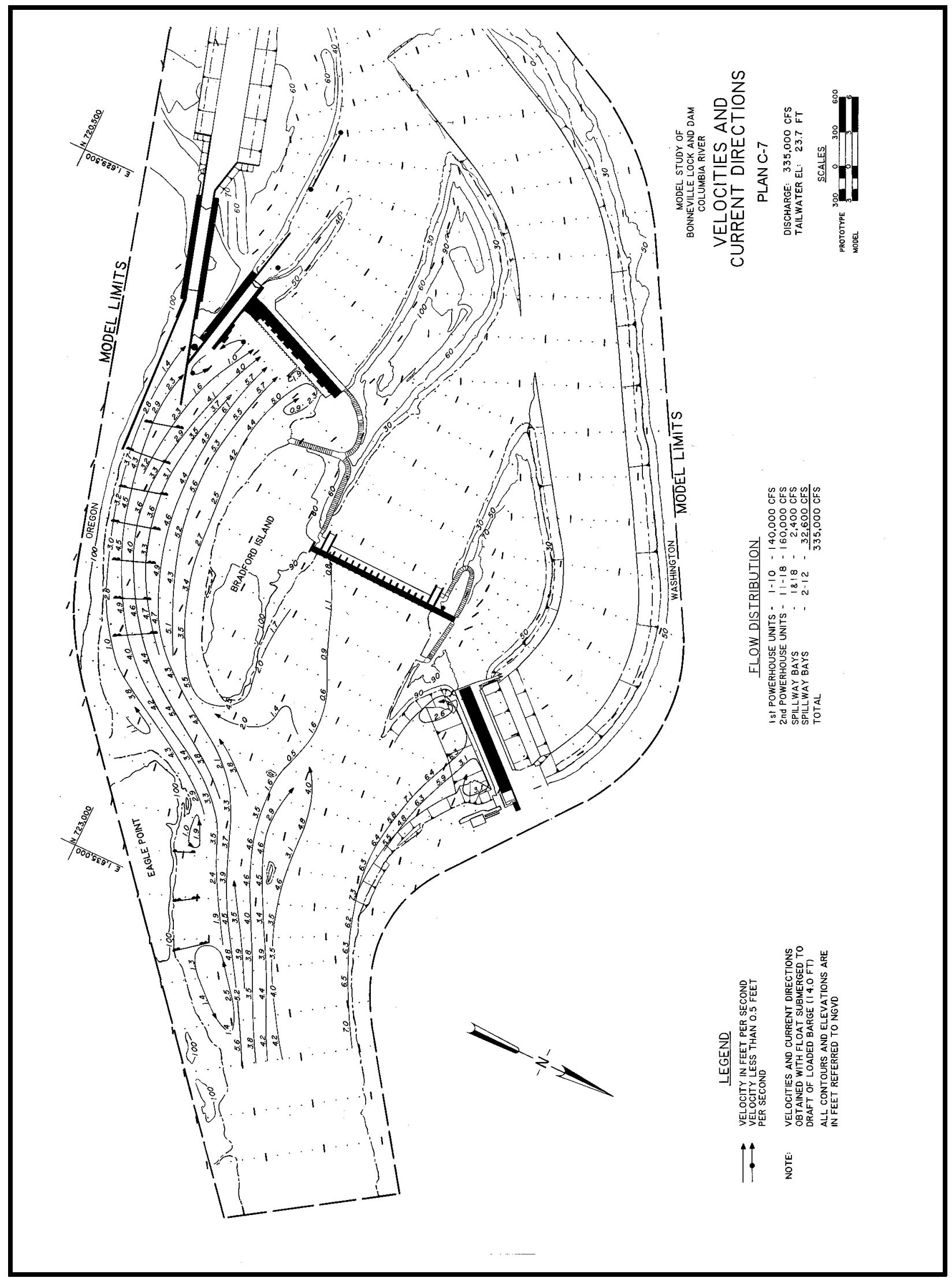

Plate 41 


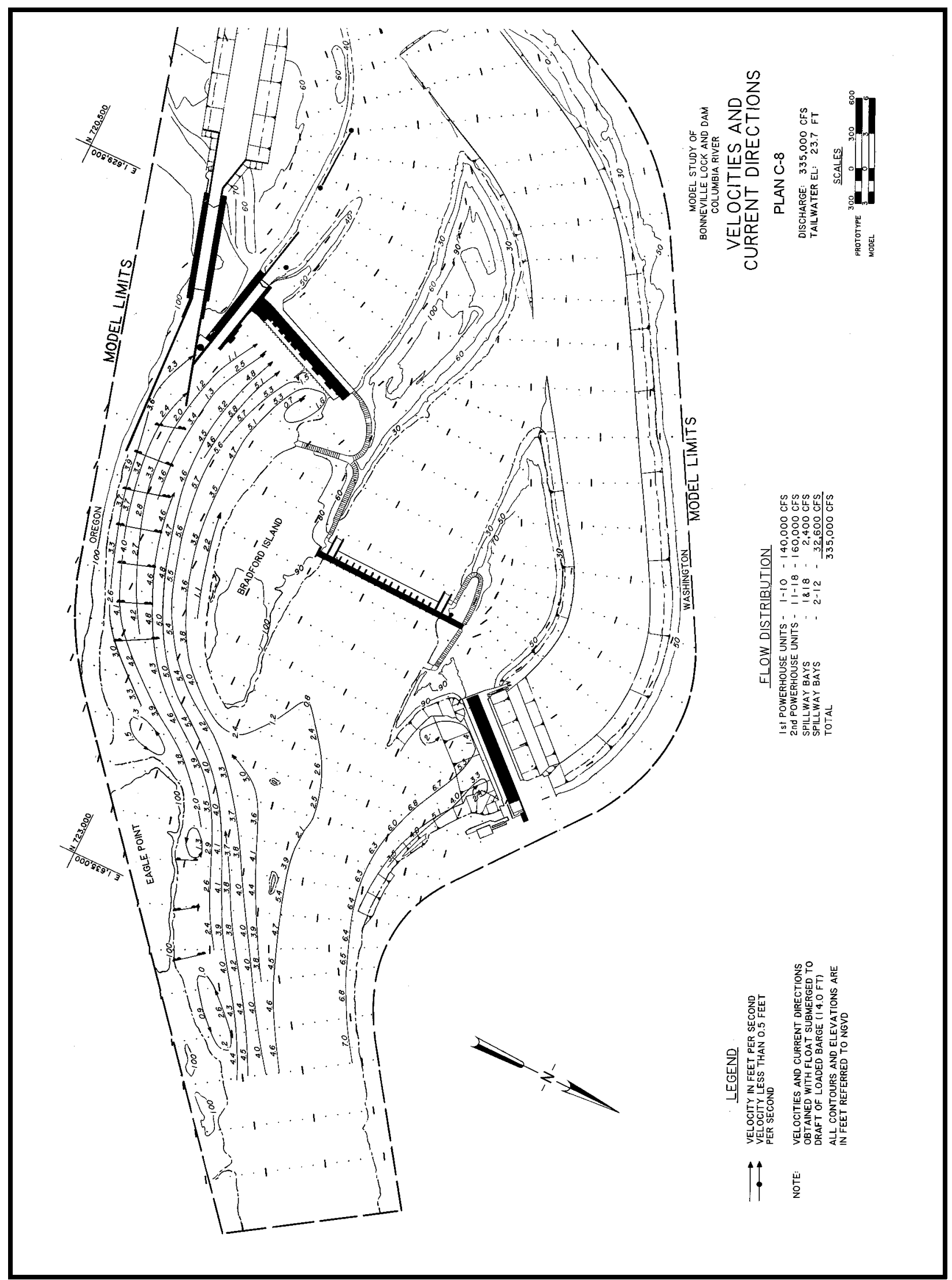

Plate 42 


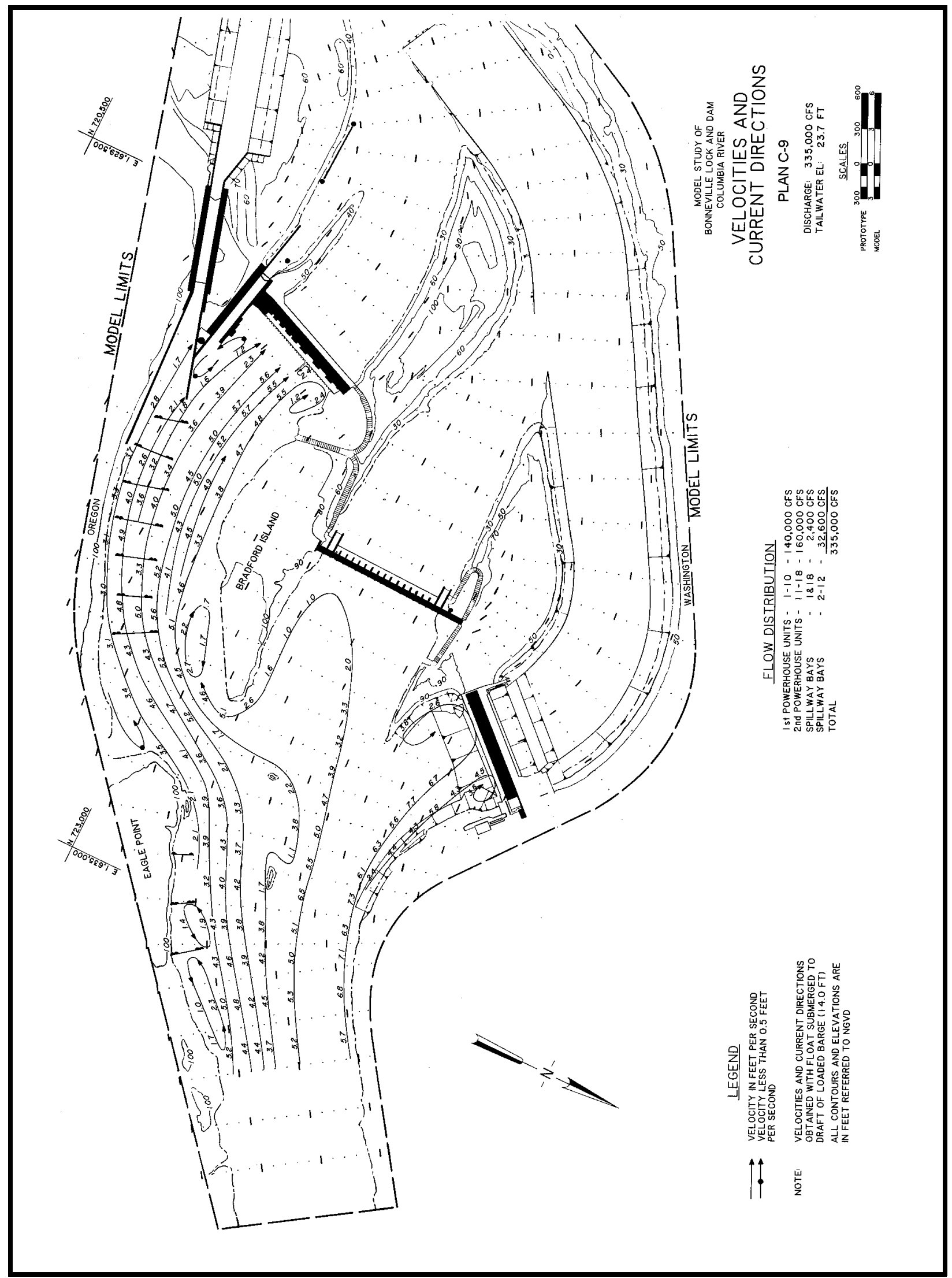

Plate 43 


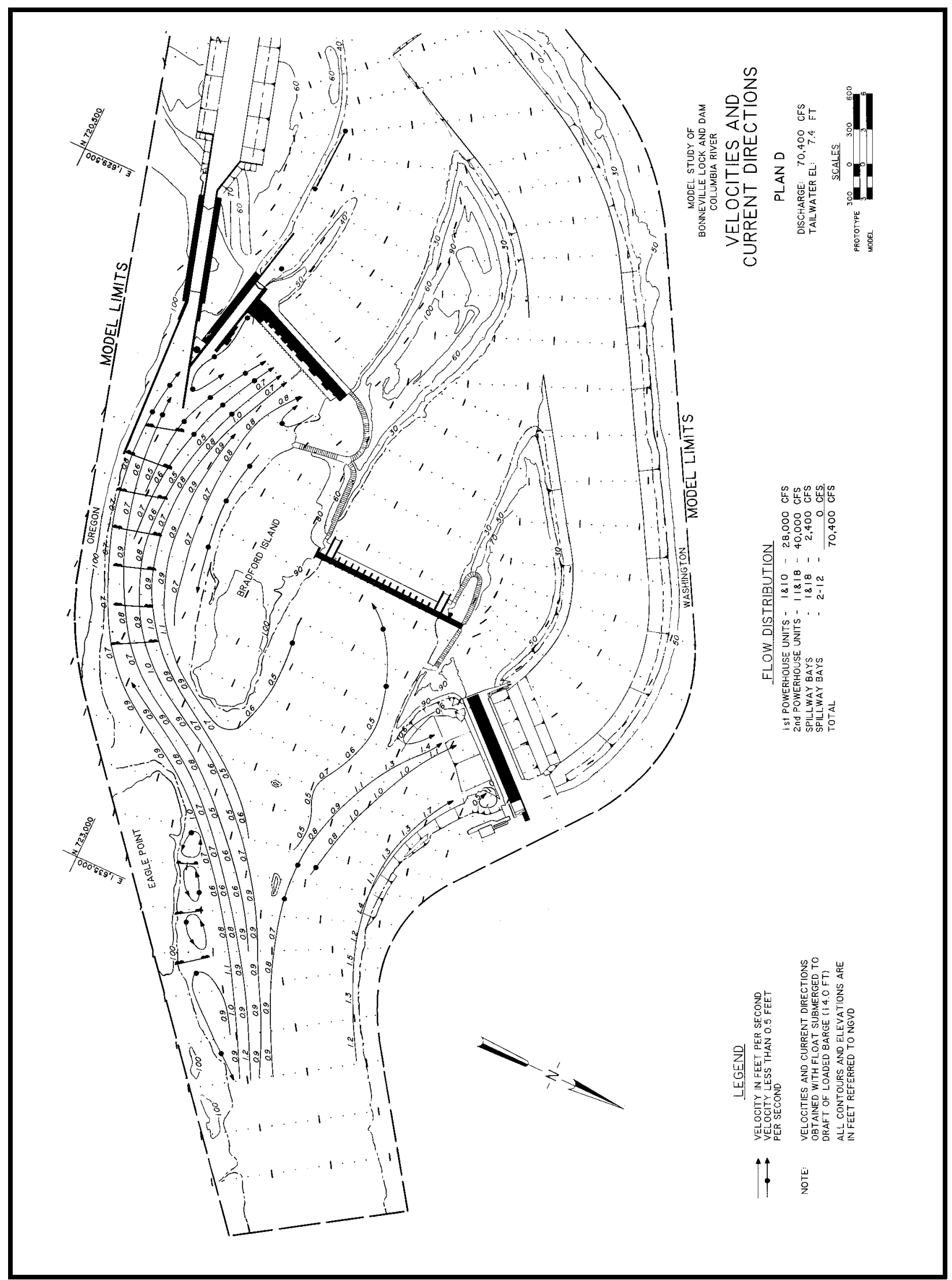

Plate 44 


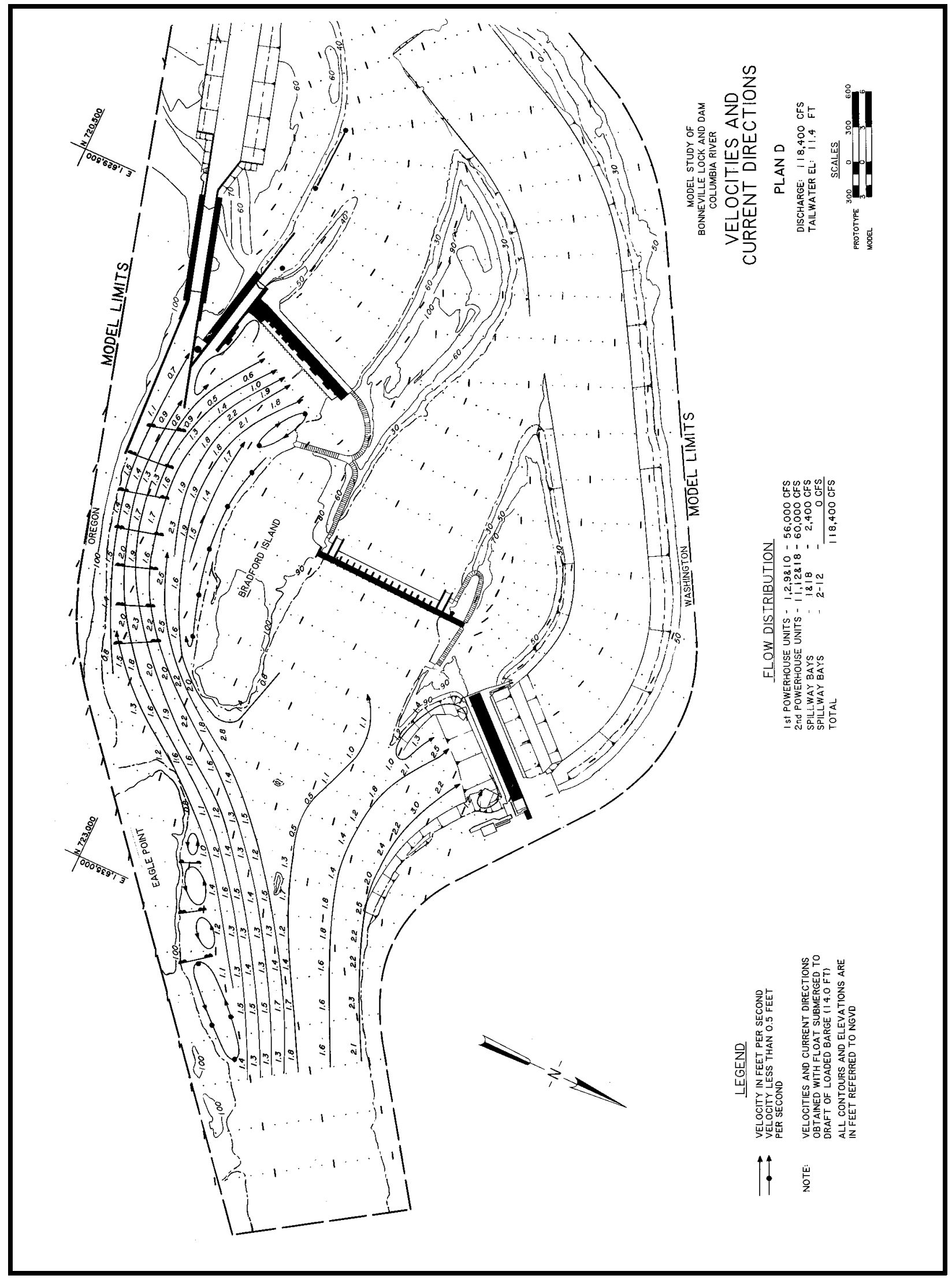

Plate 45 


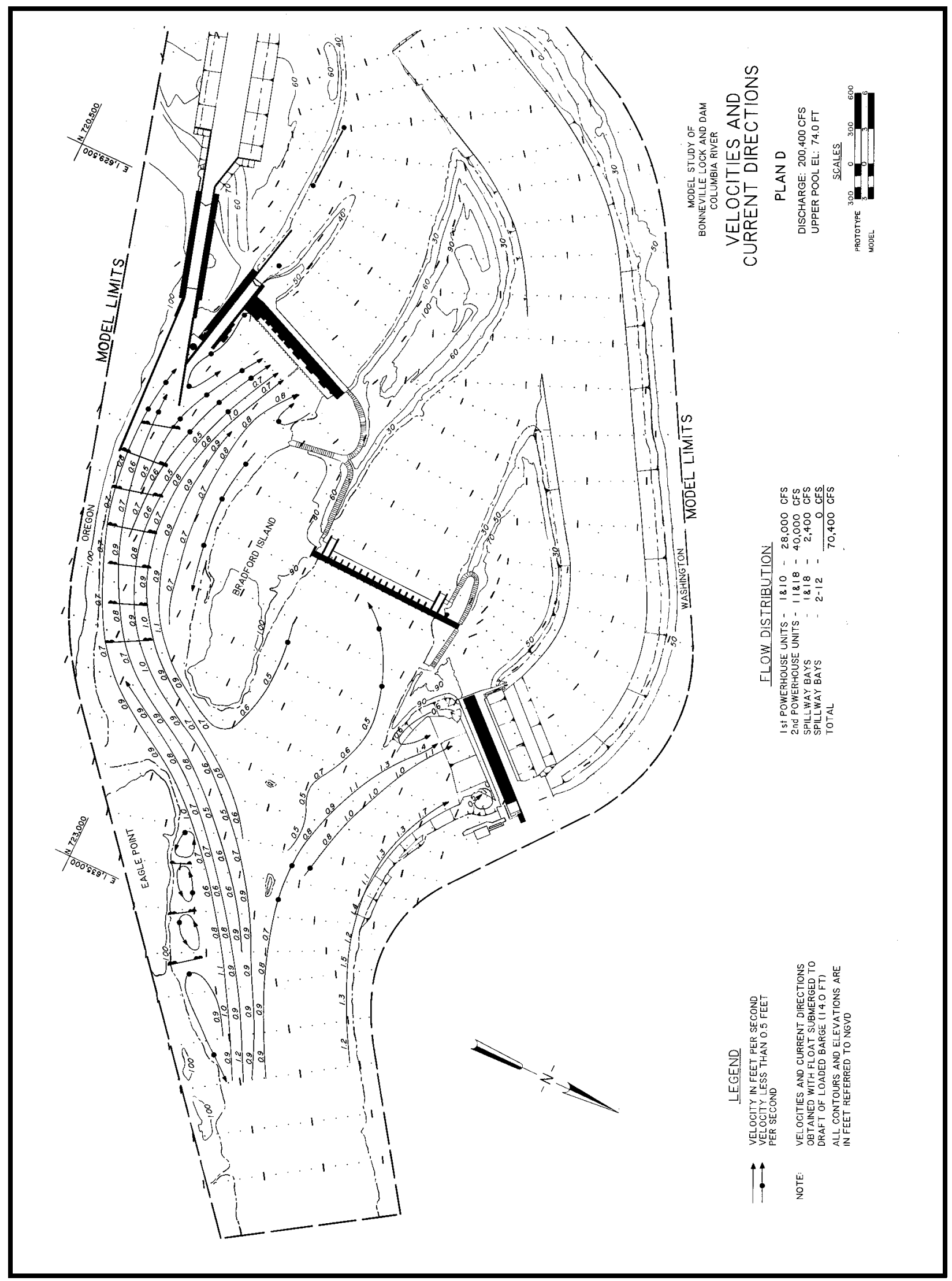

Plate 46 


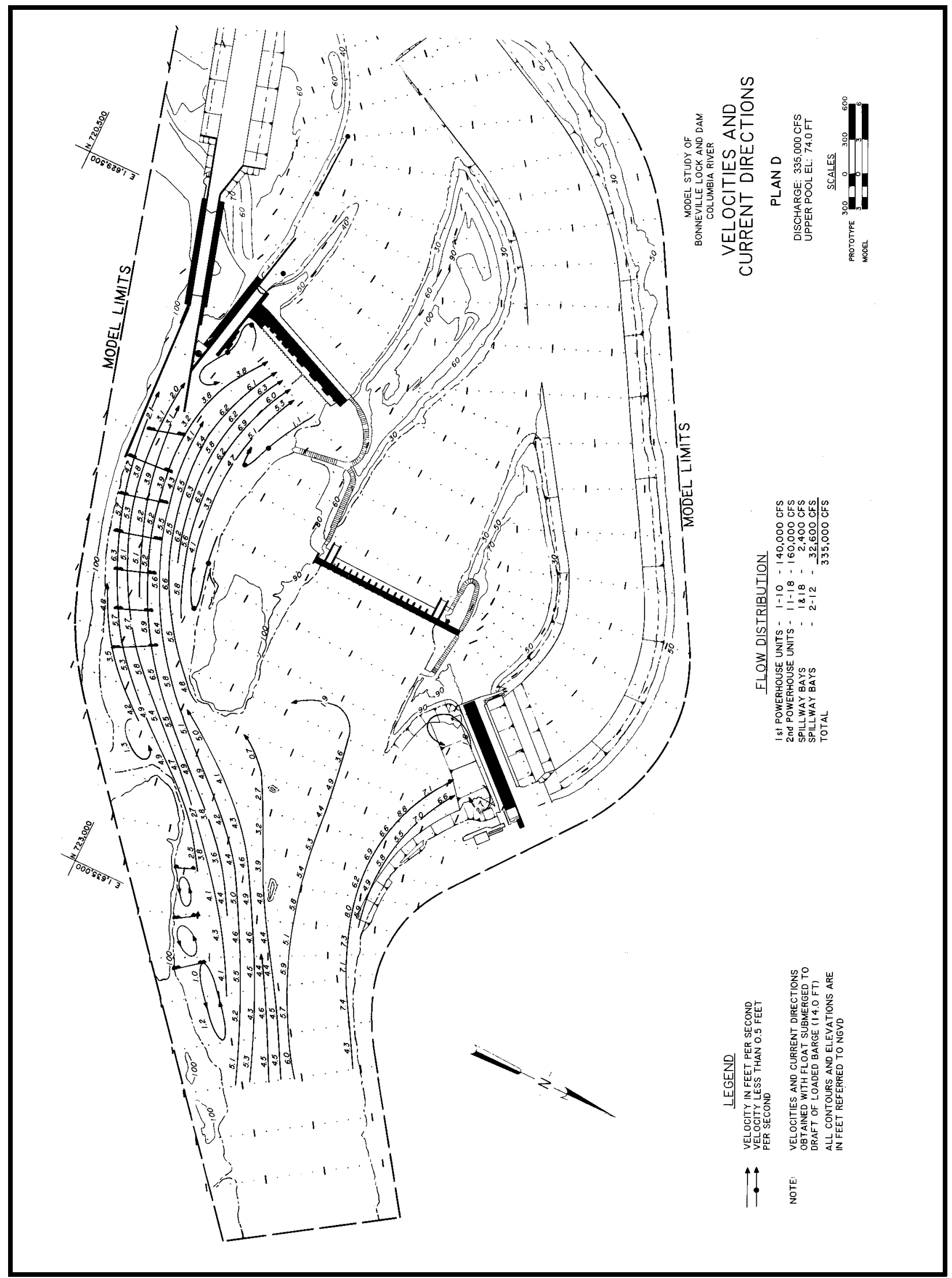

Plate 47 


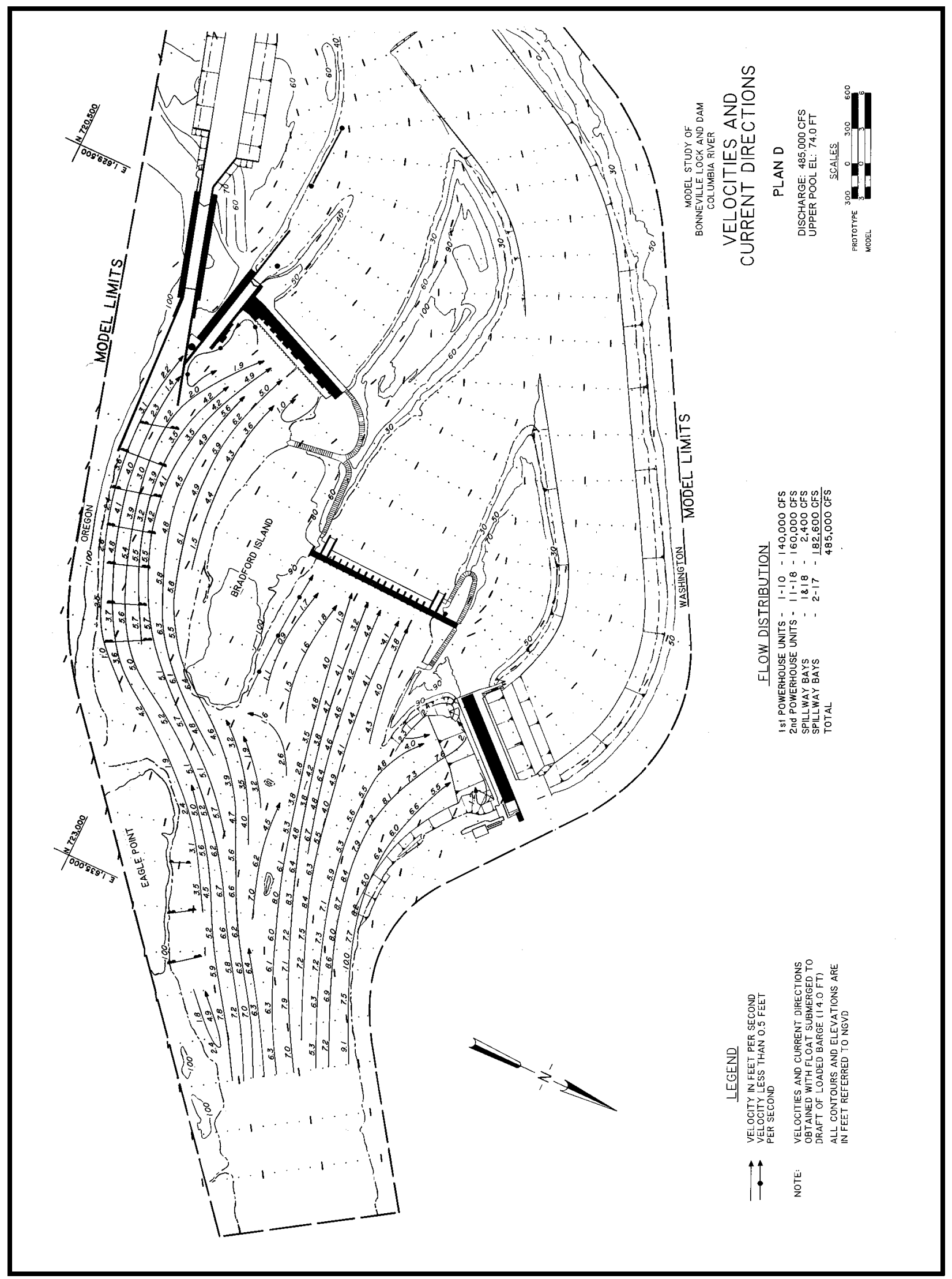

Plate 48 


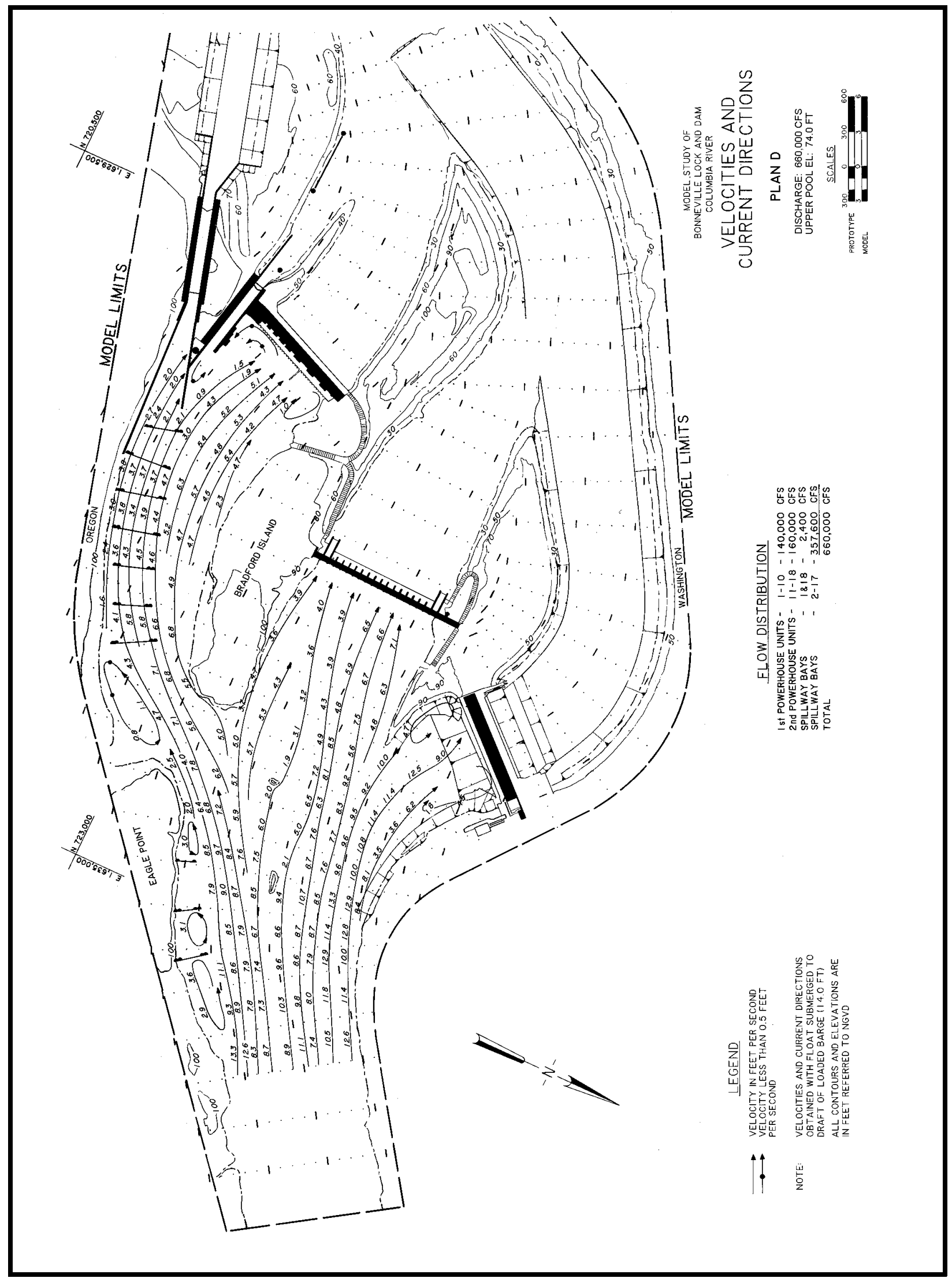

Plate 49 


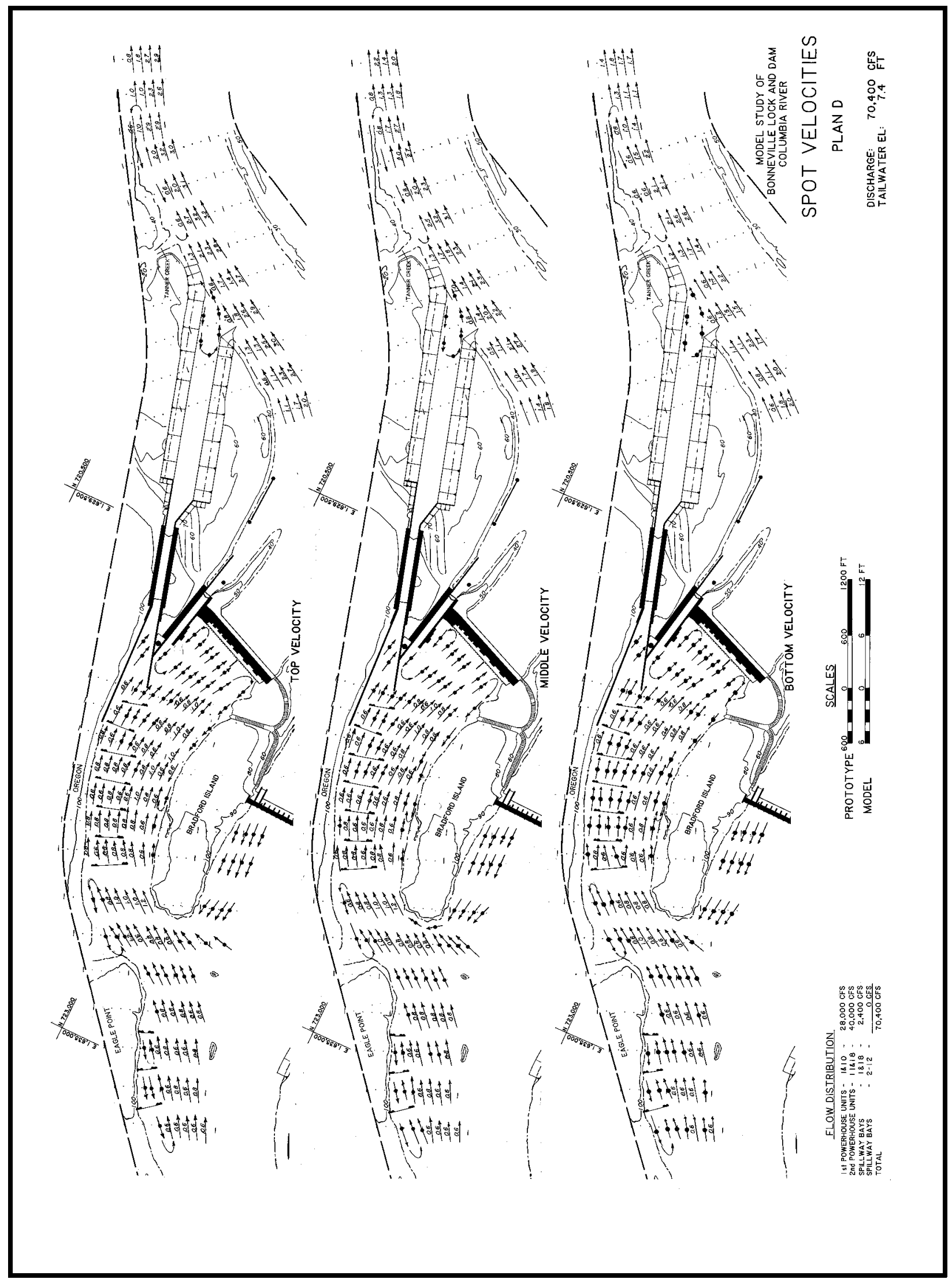

Plate 50 


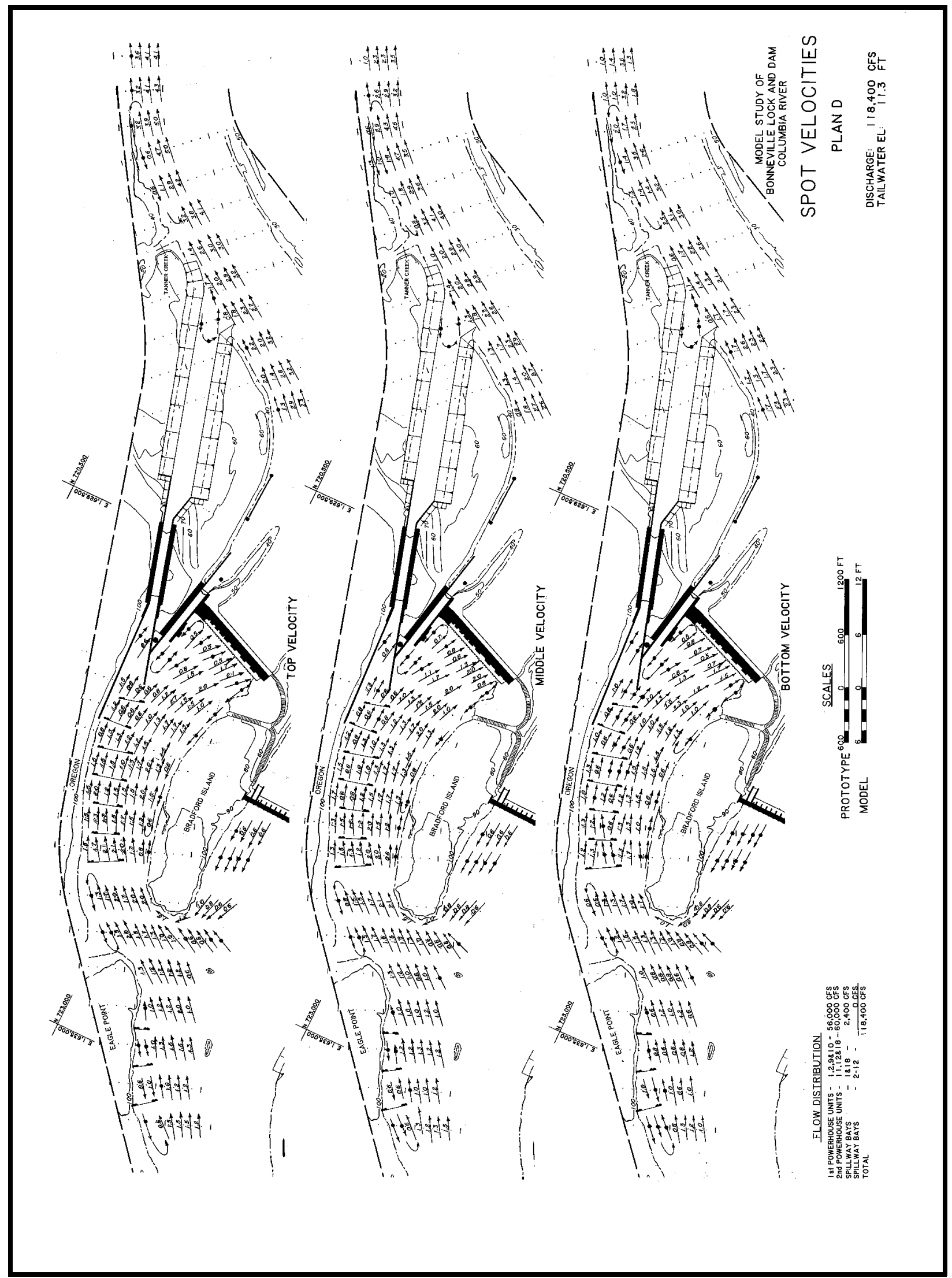

Plate 51 


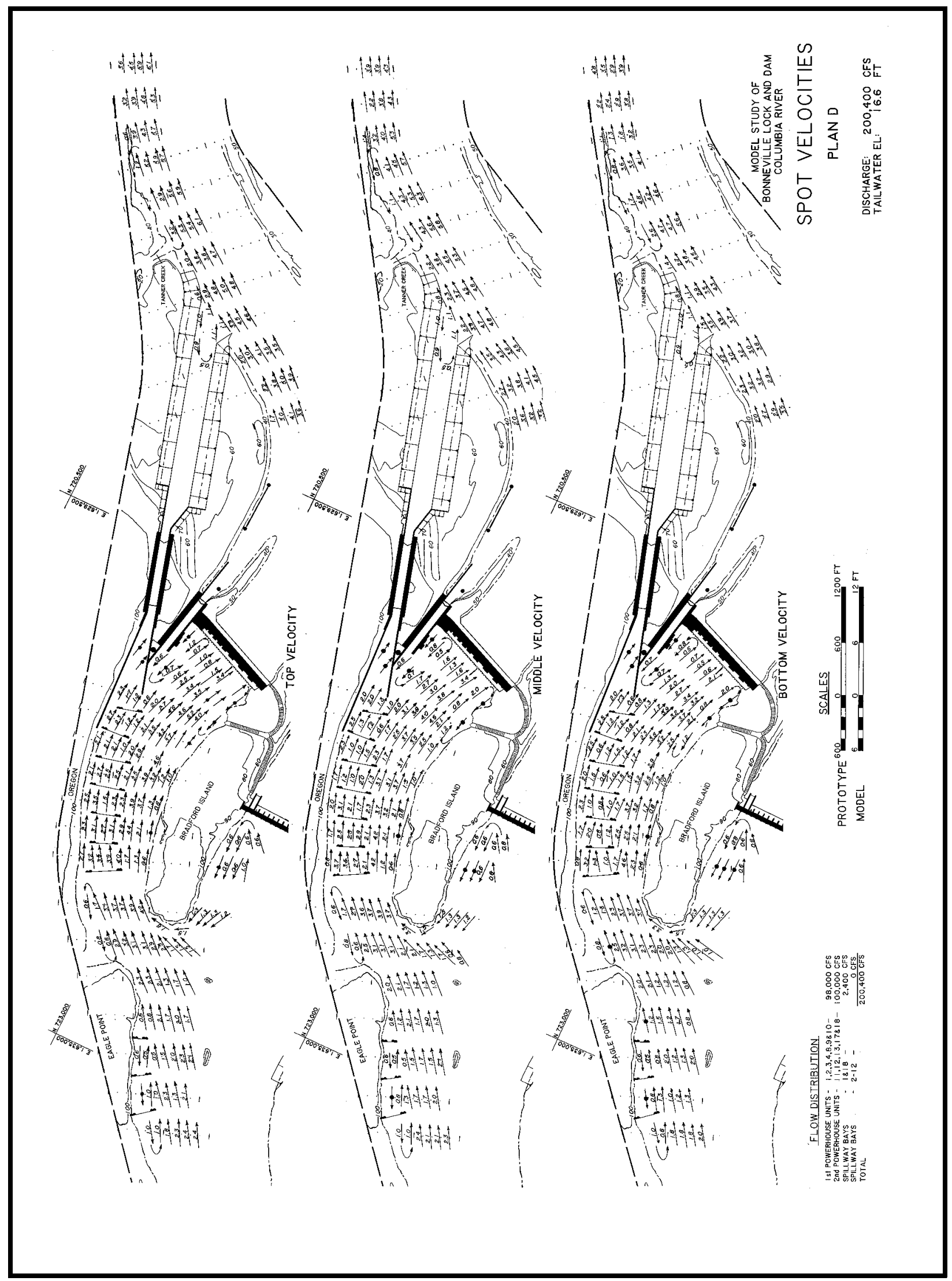

Plate 52 


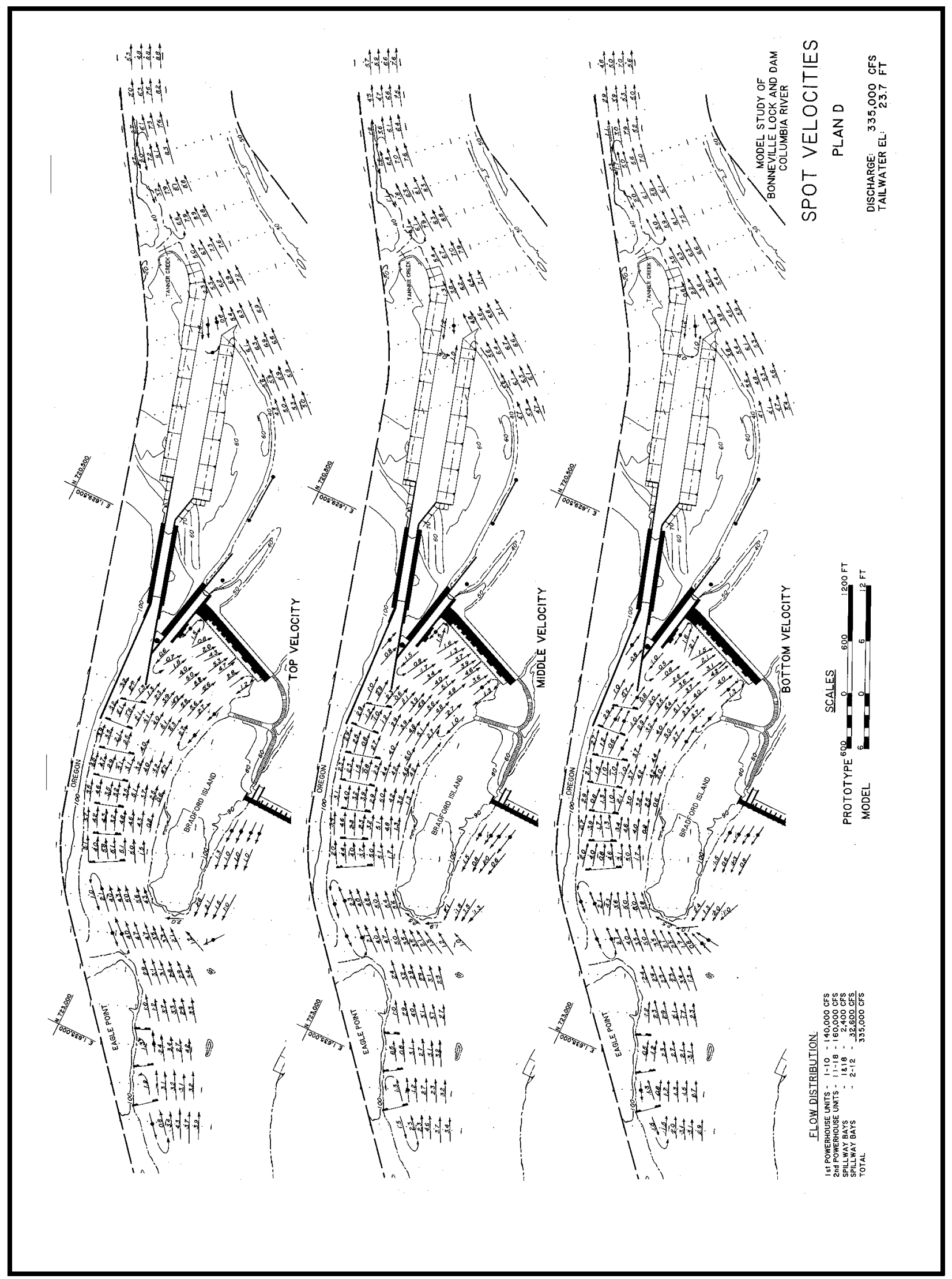

Plate 53 


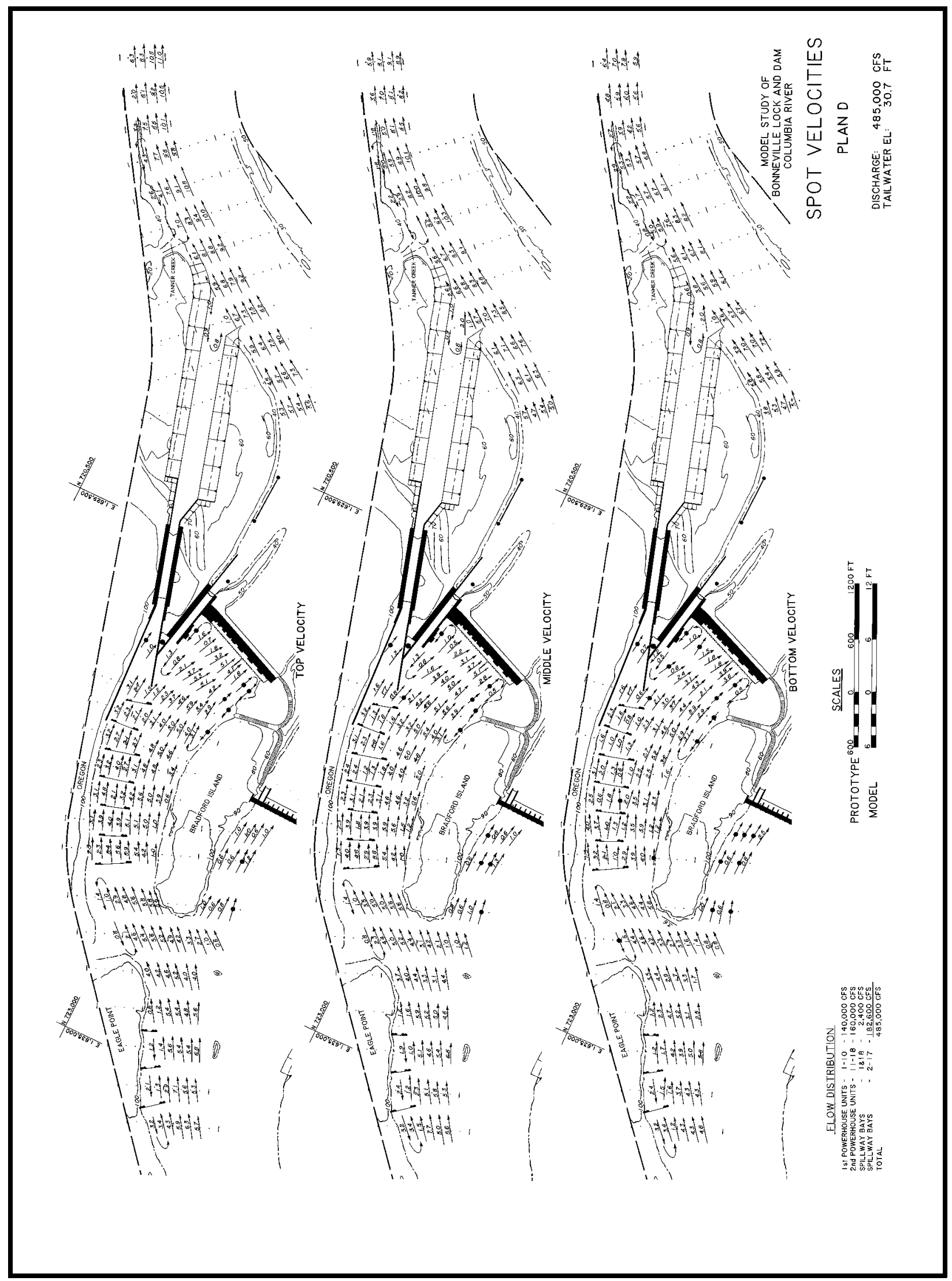

Plate 54 


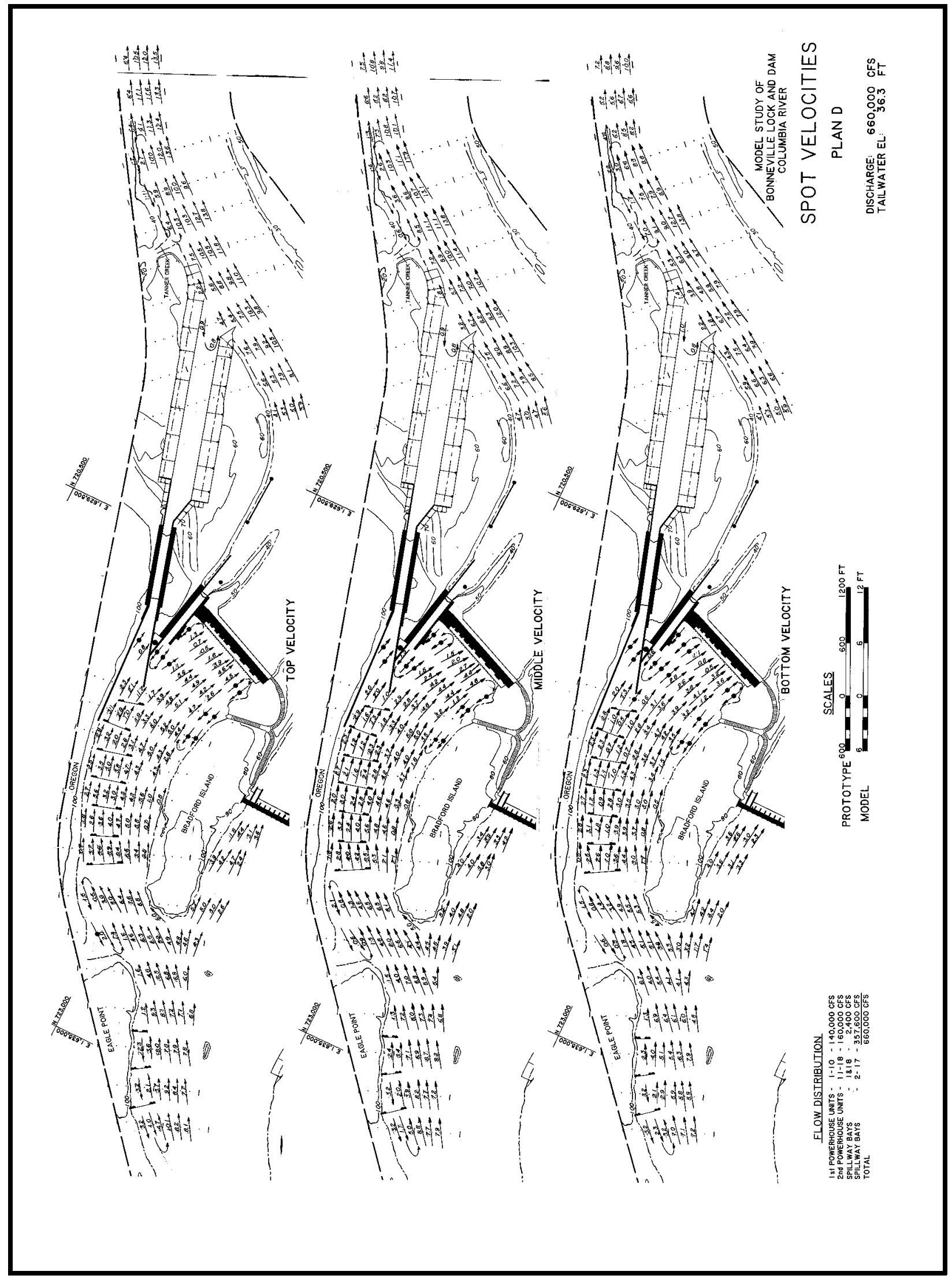

Plate 55 


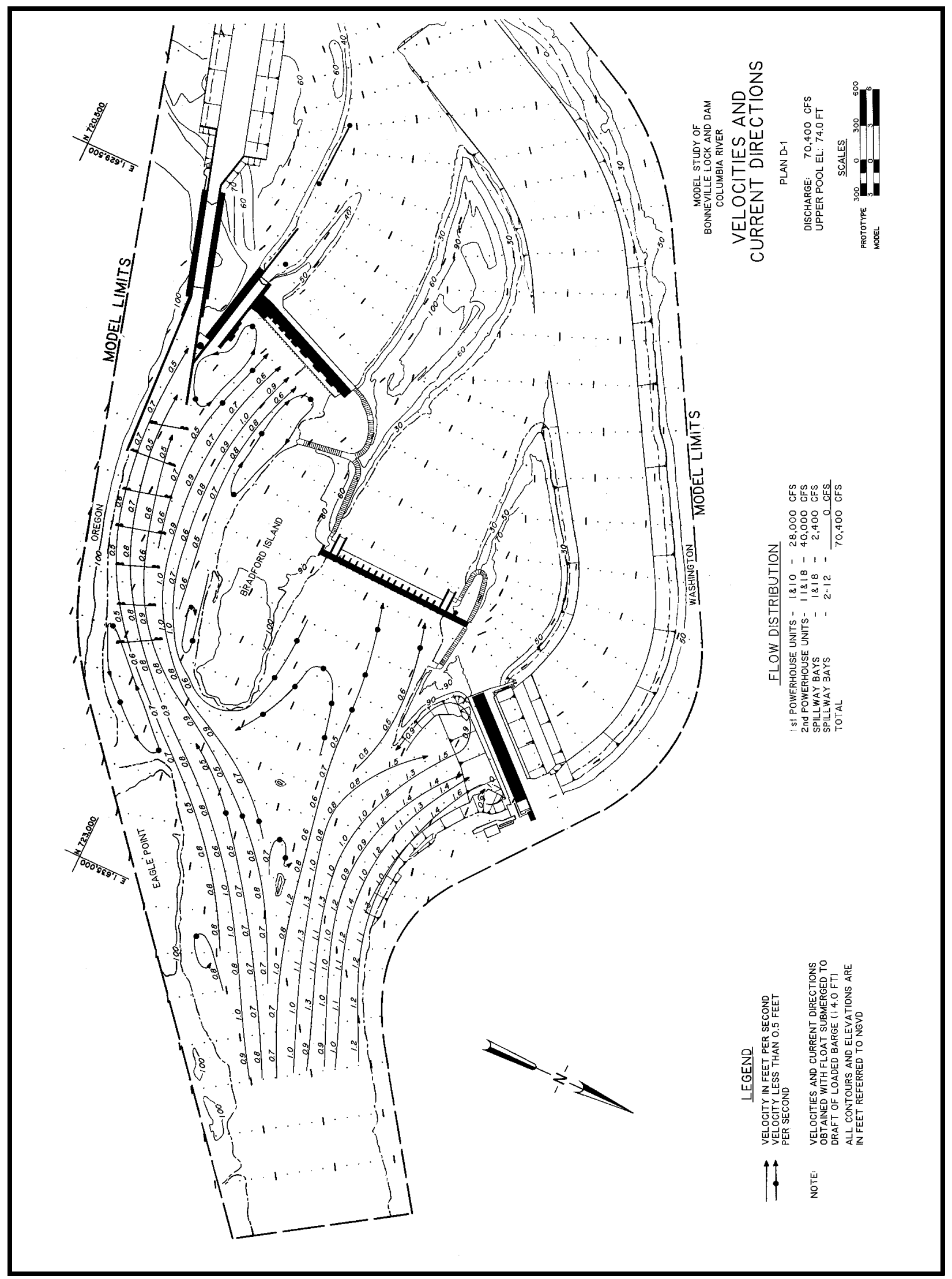

Plate 56 


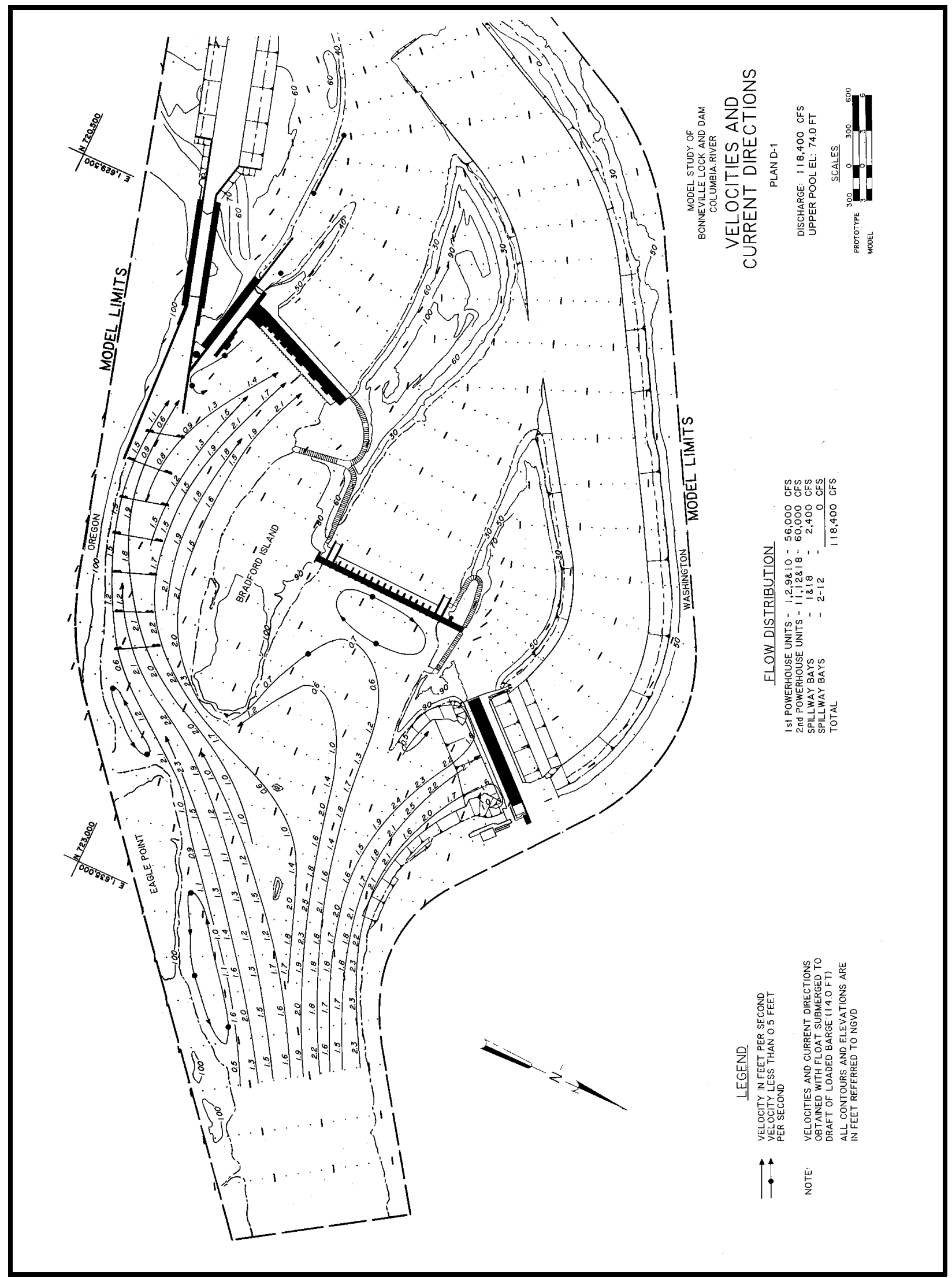

Plate 57 


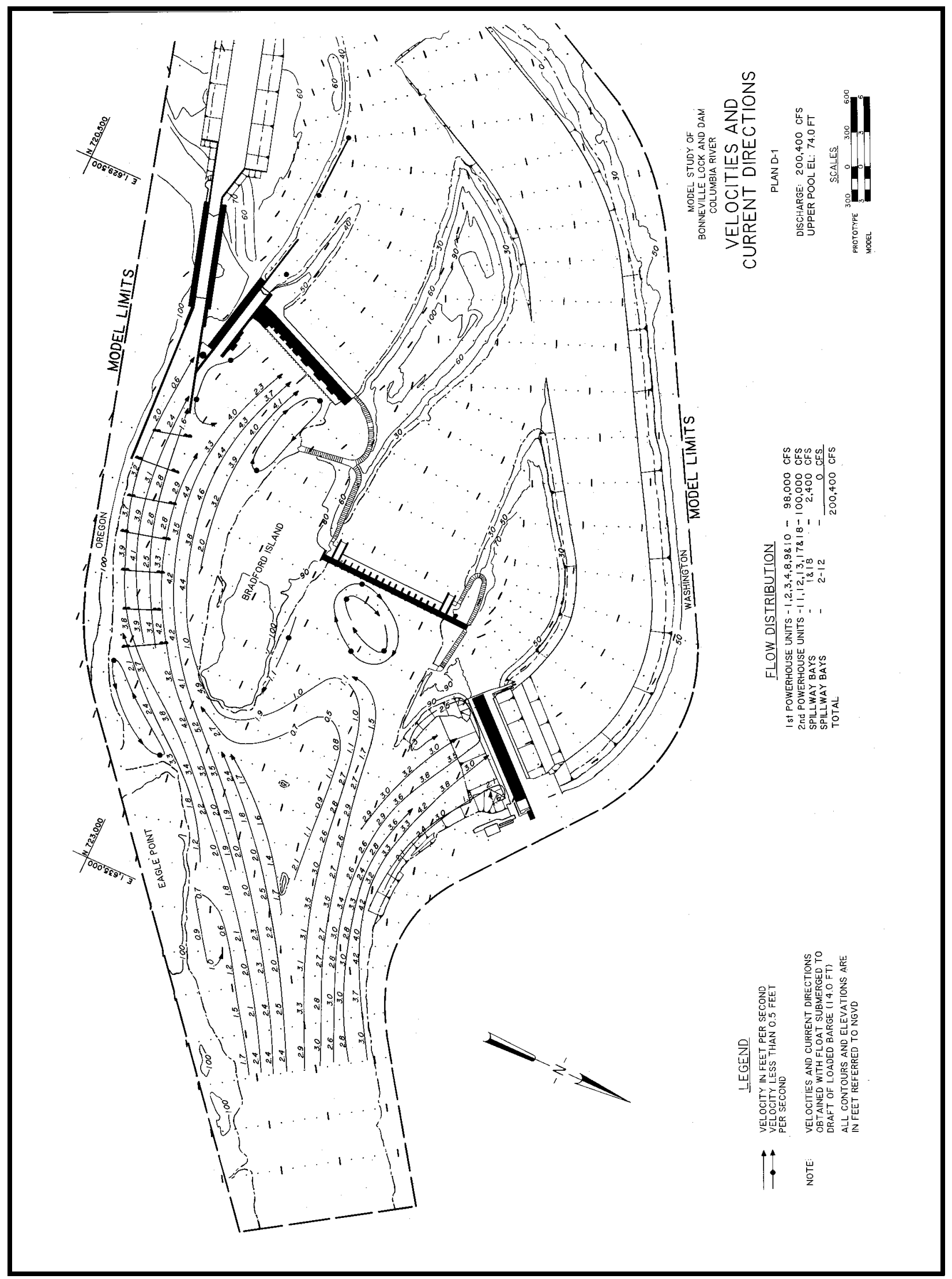

Plate 58 


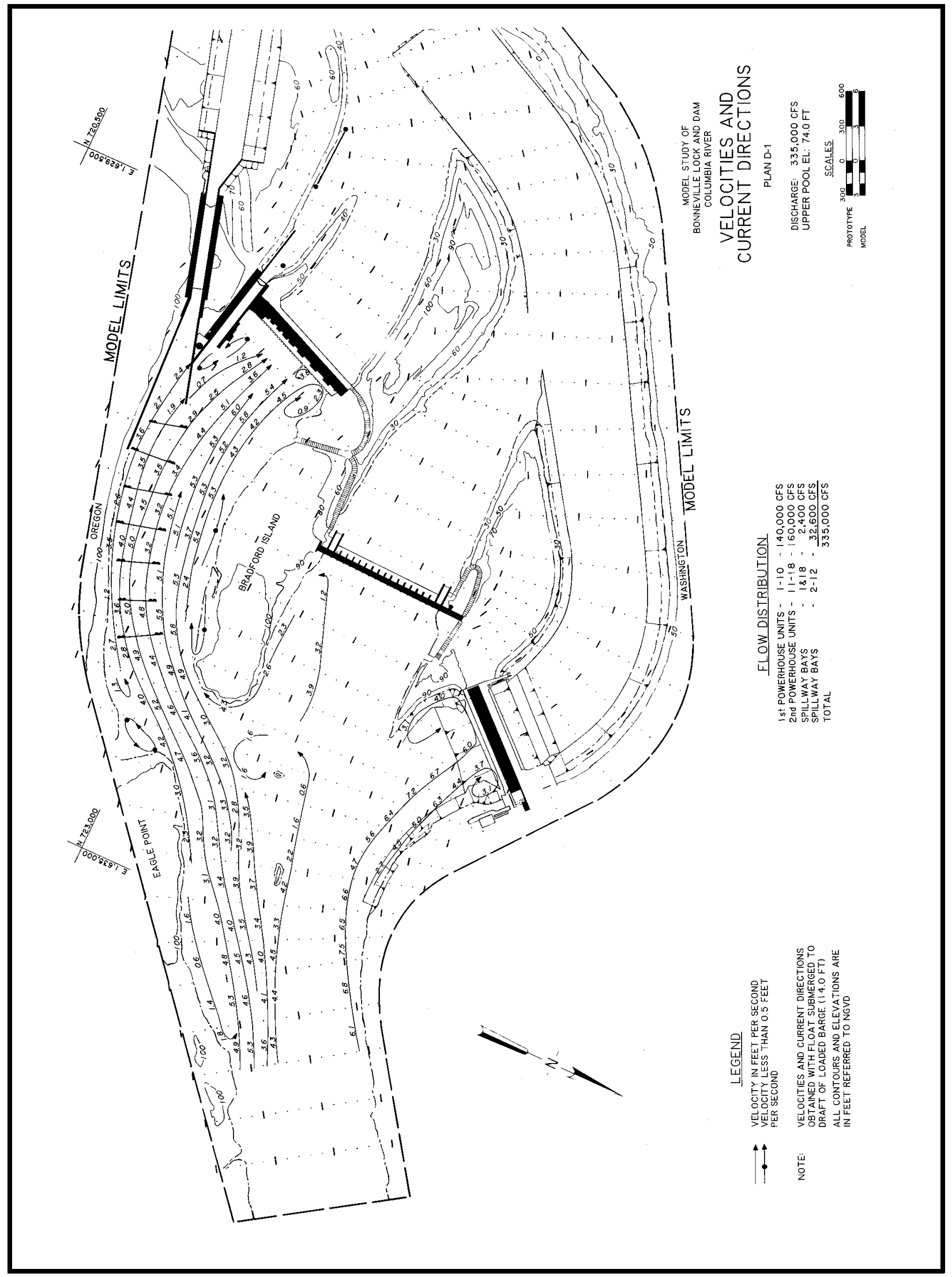

Plate 59 


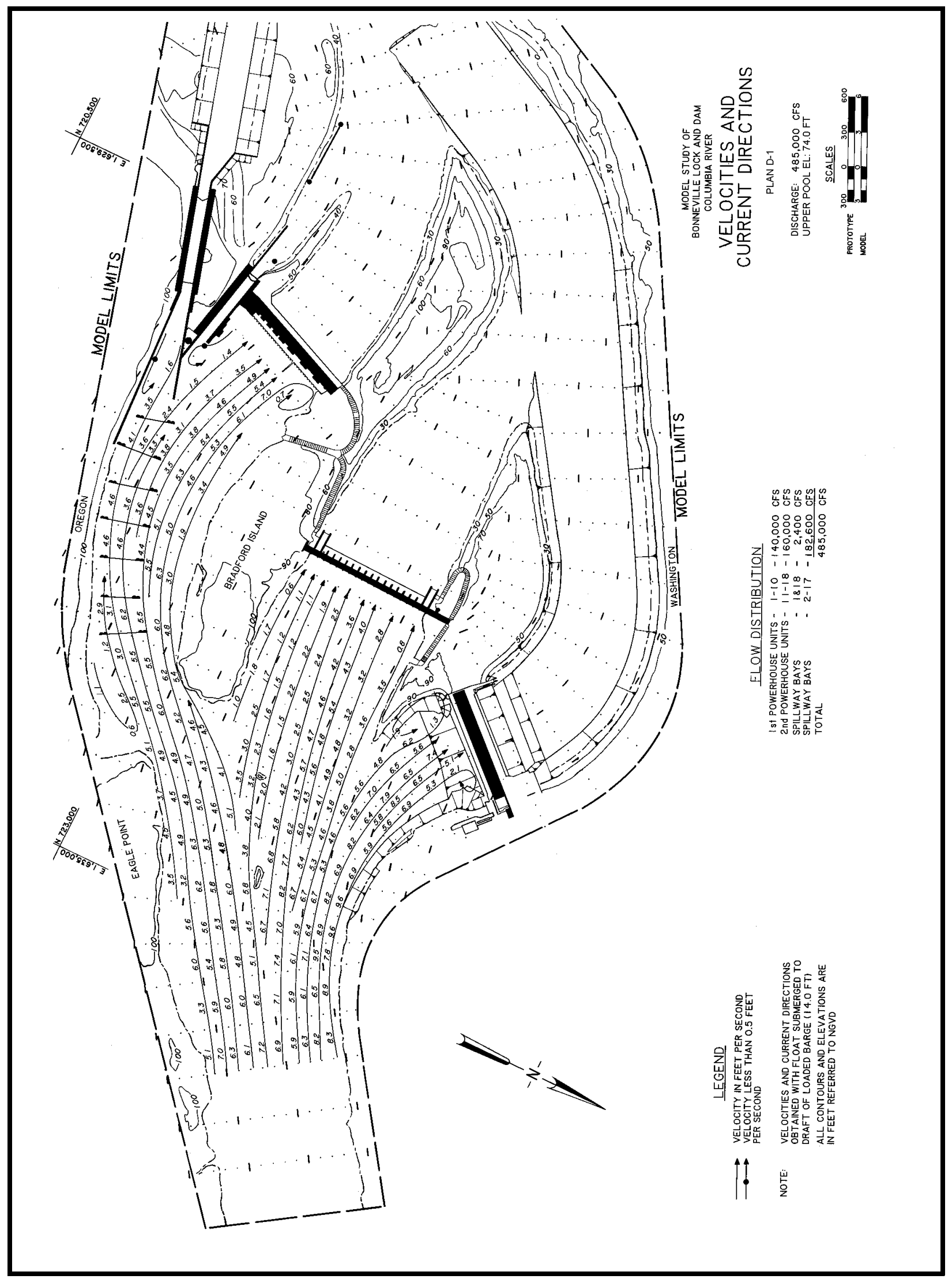

Plate 60 


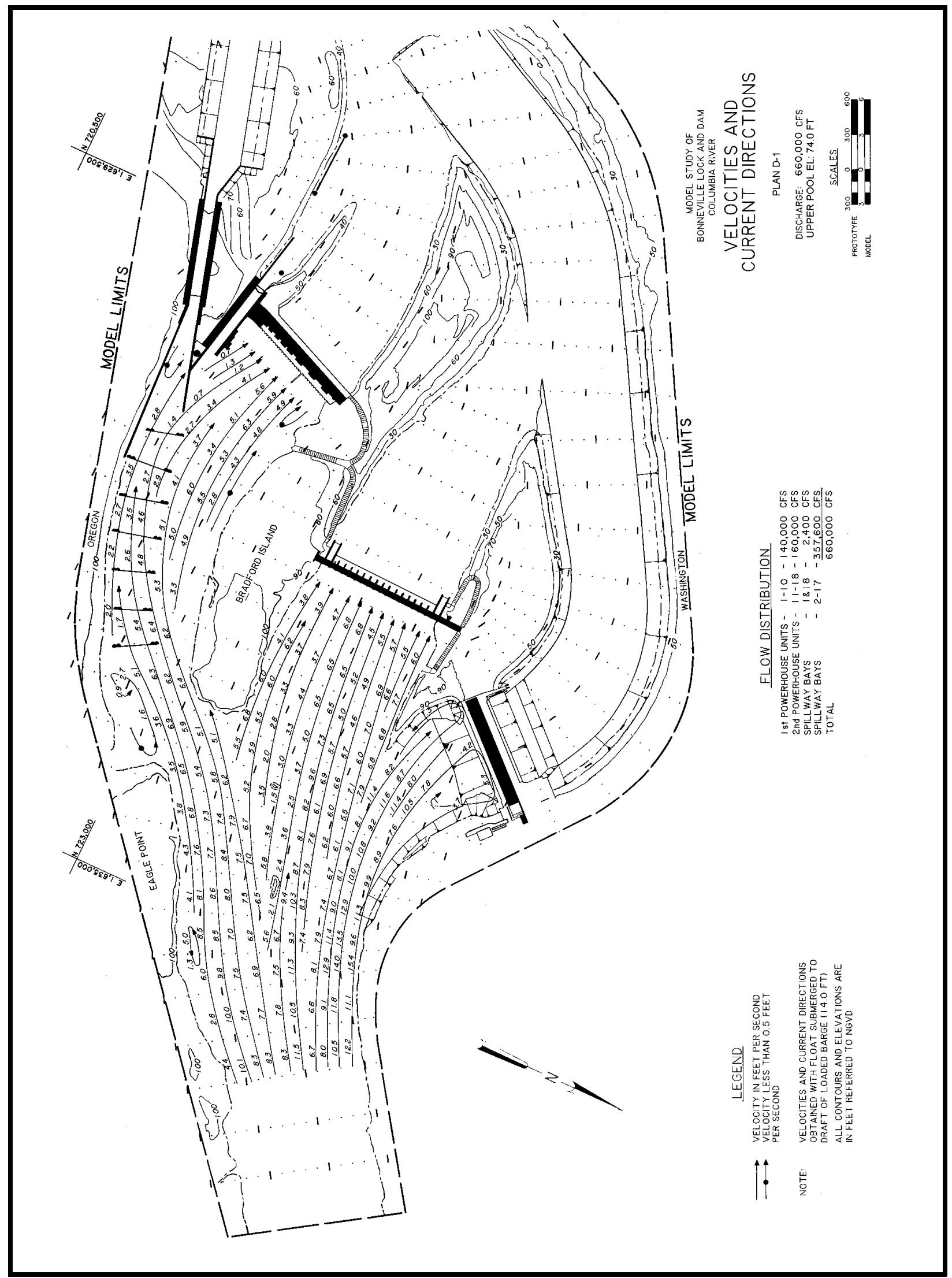

Plate 61 


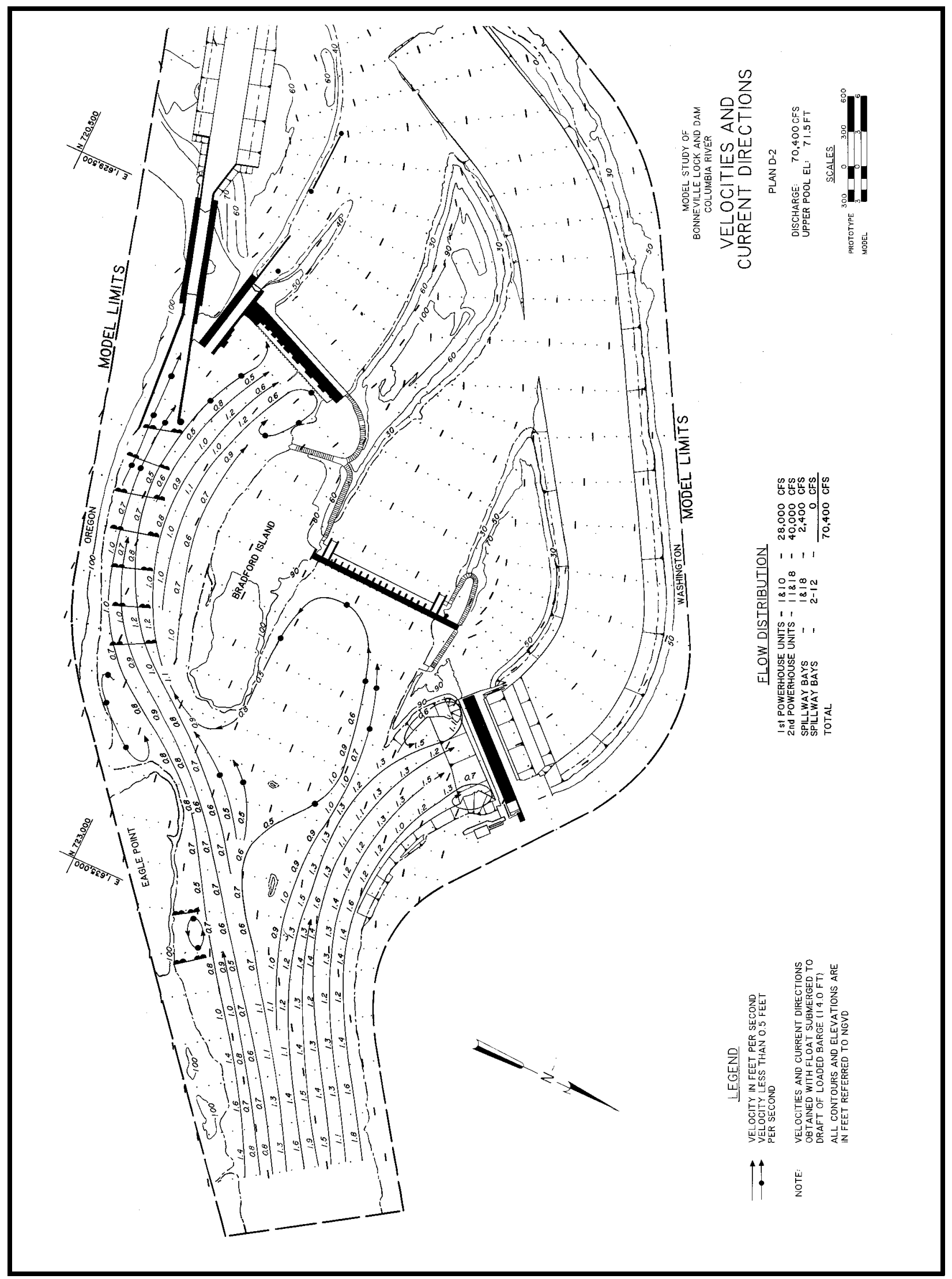

Plate 62 


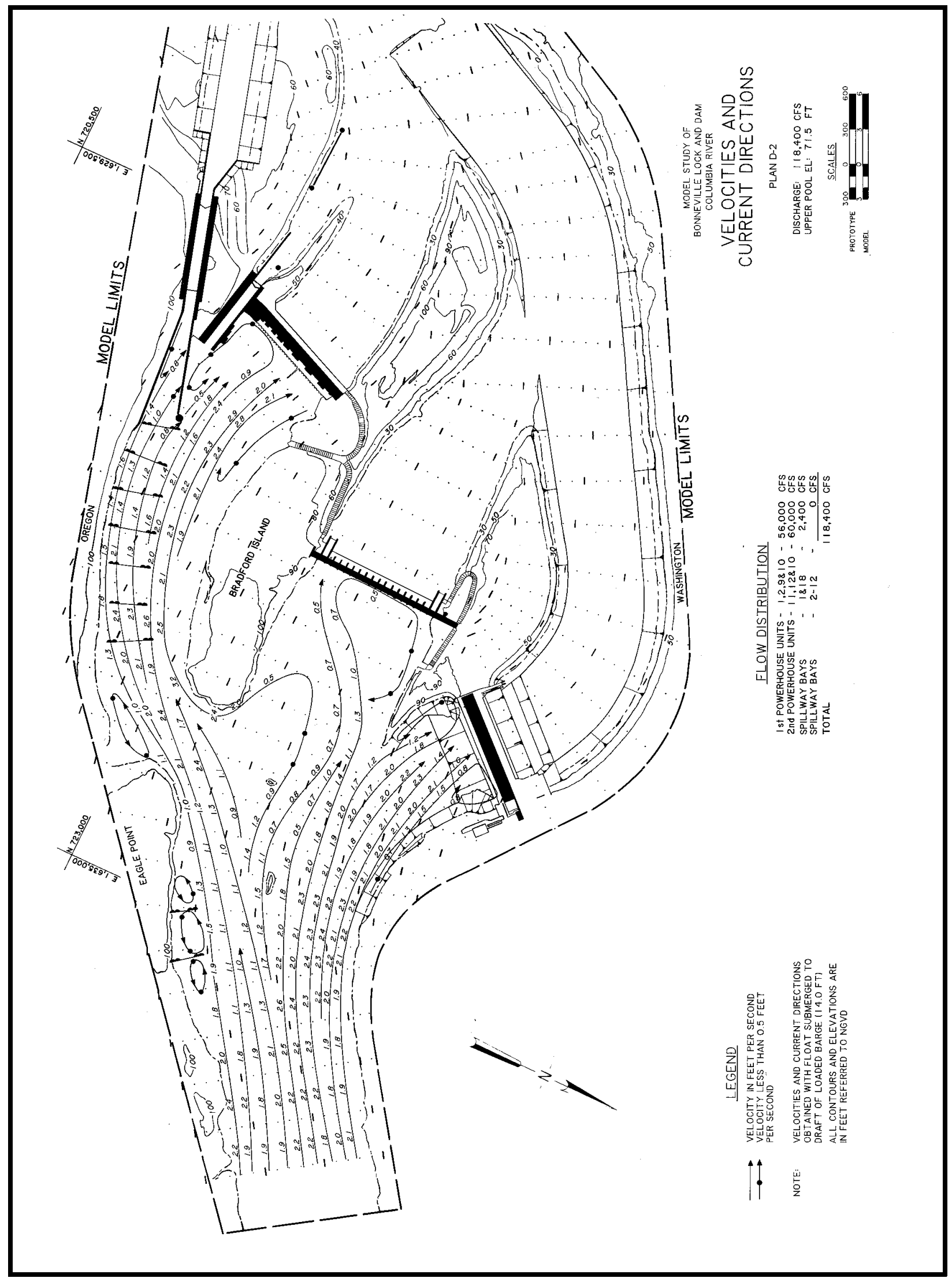

Plate 63 


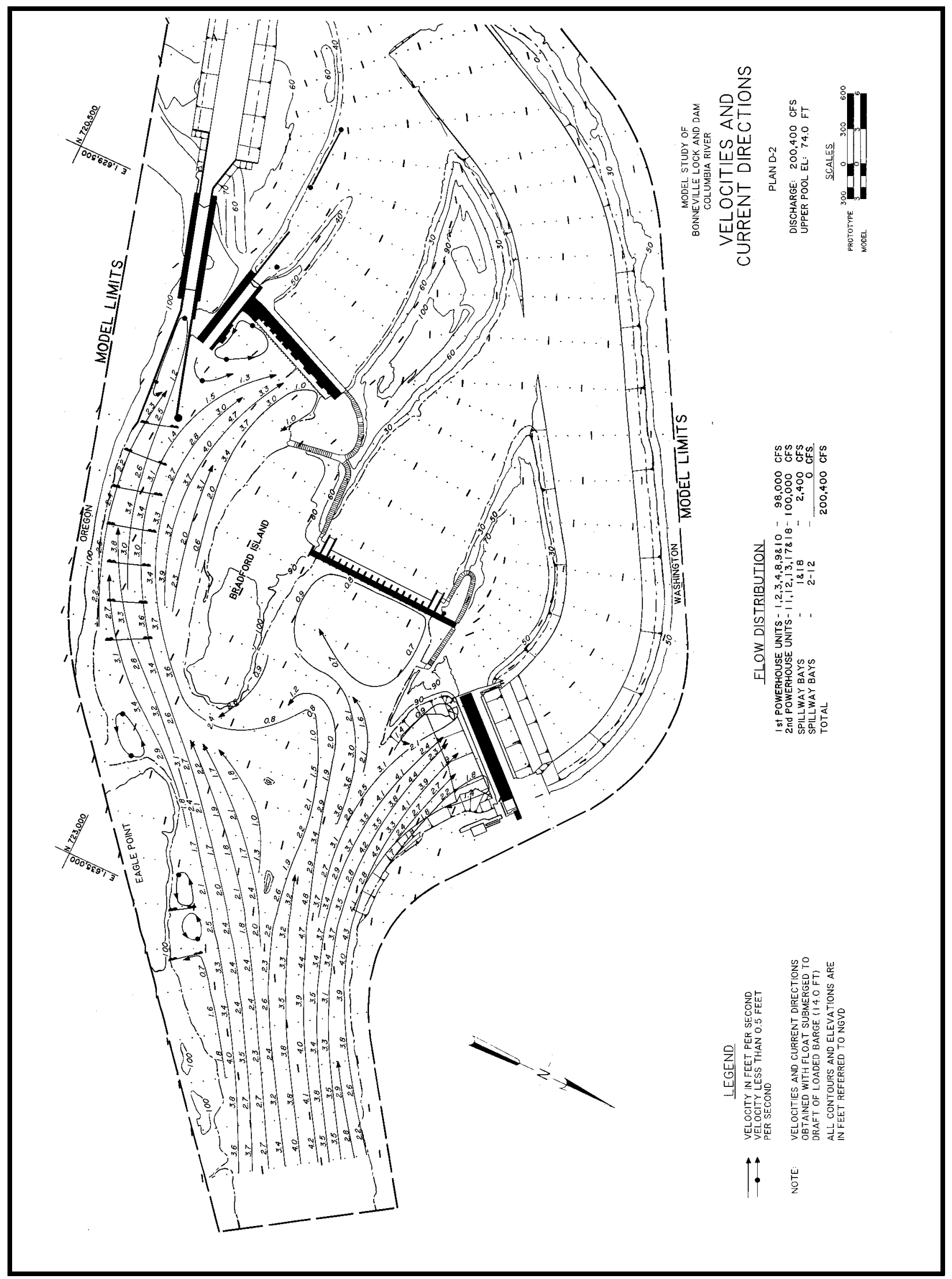

Plate 64 


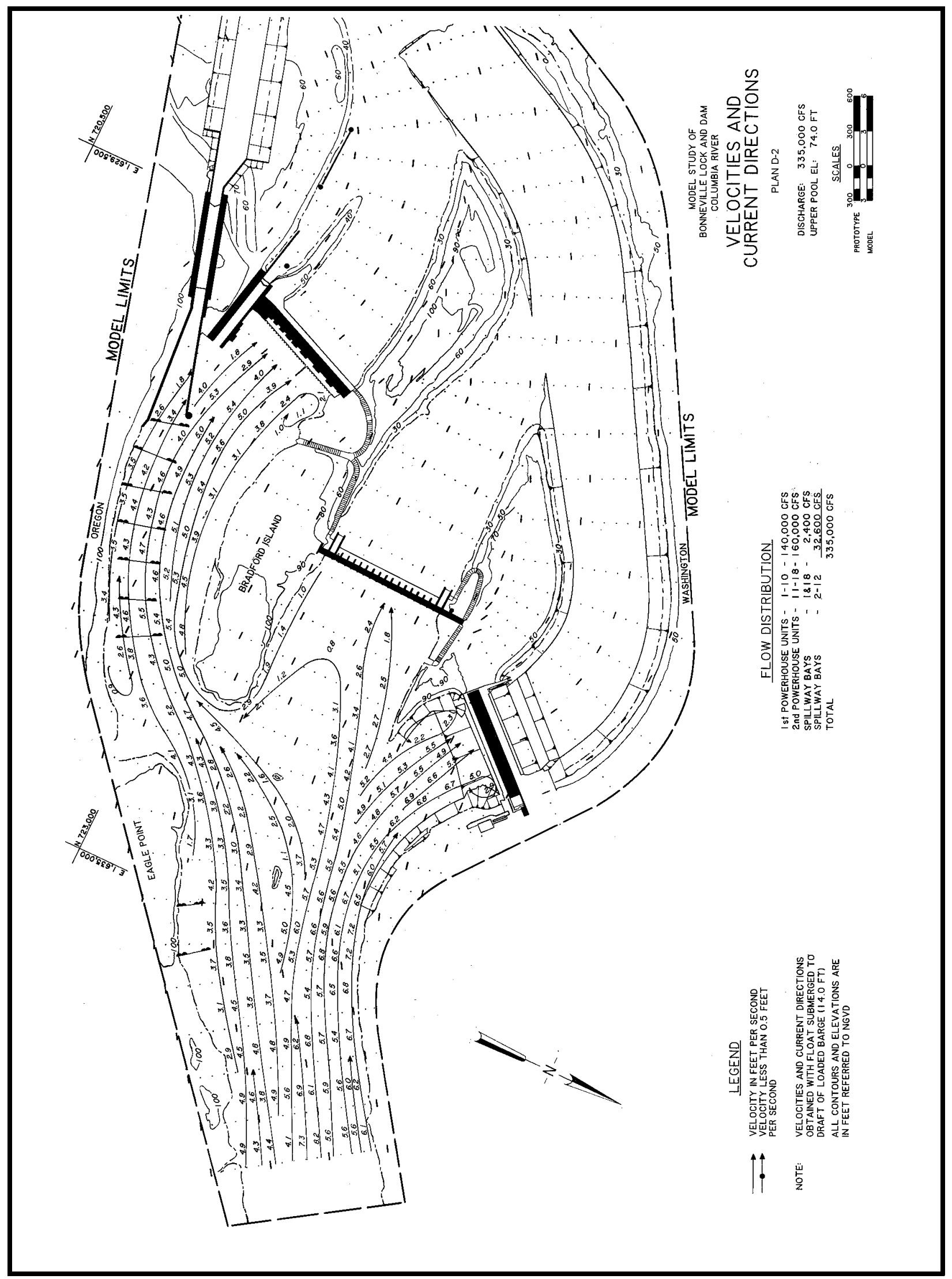

Plate 65 


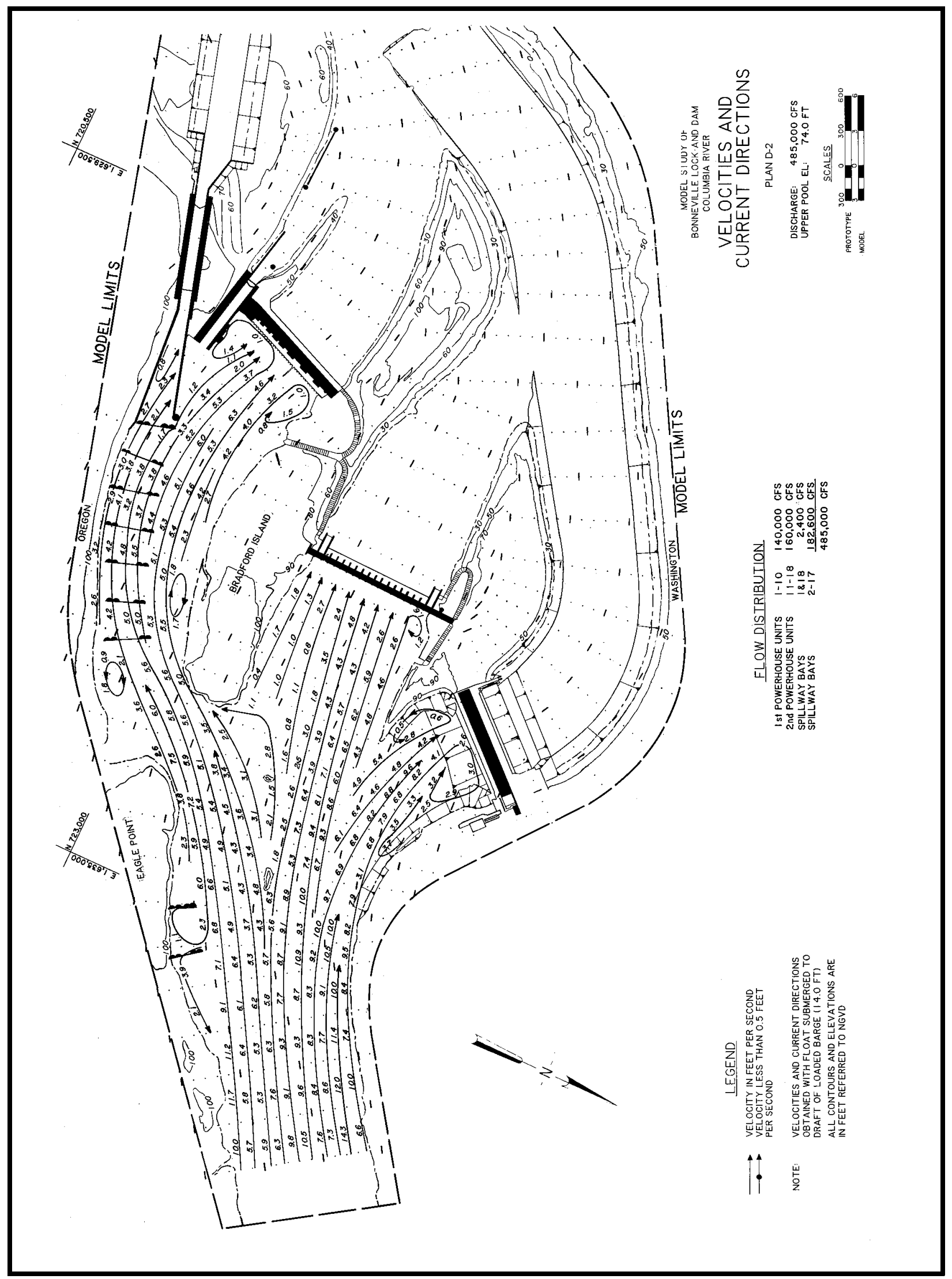

Plate 66 


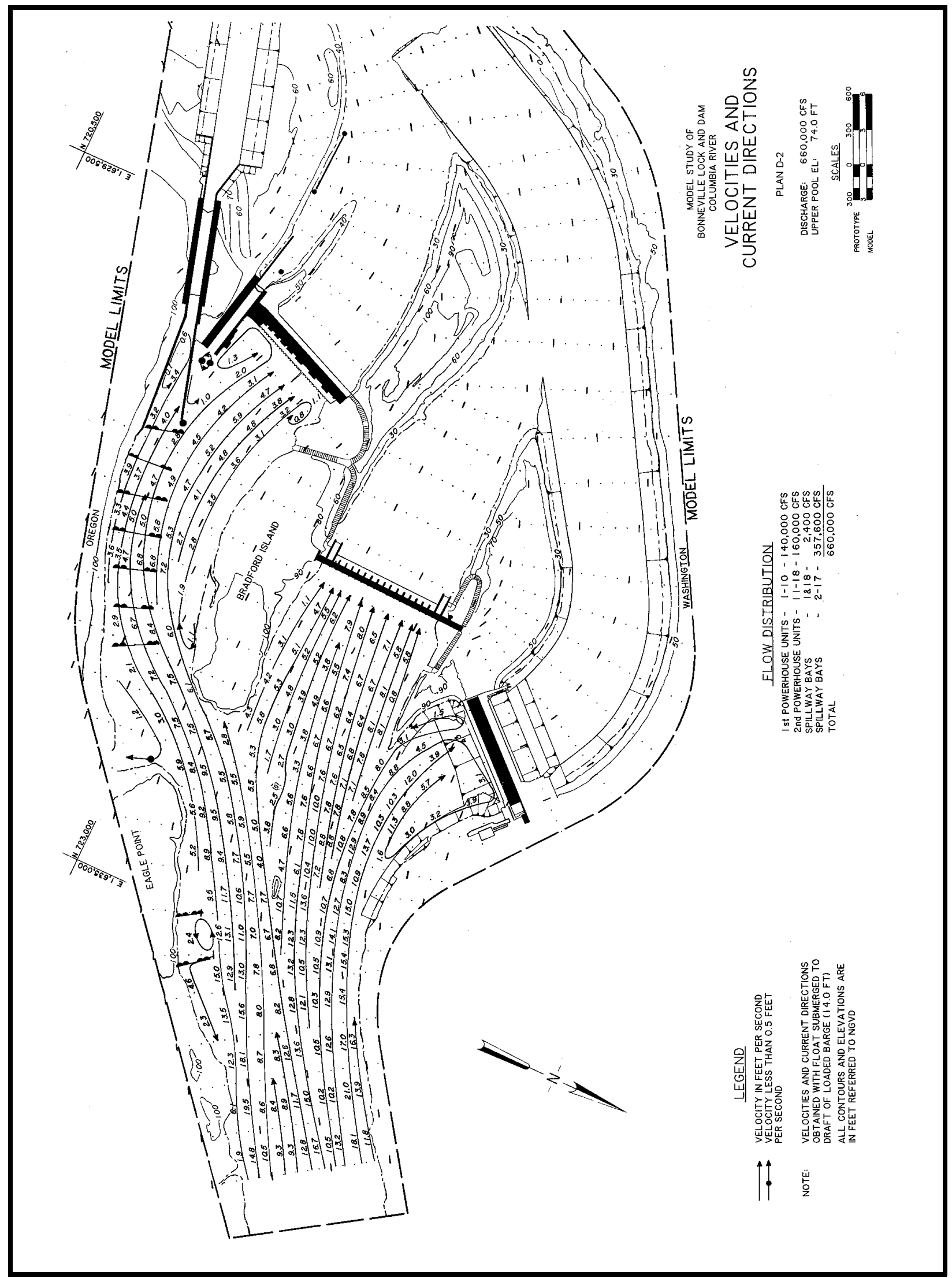

Plate 67 


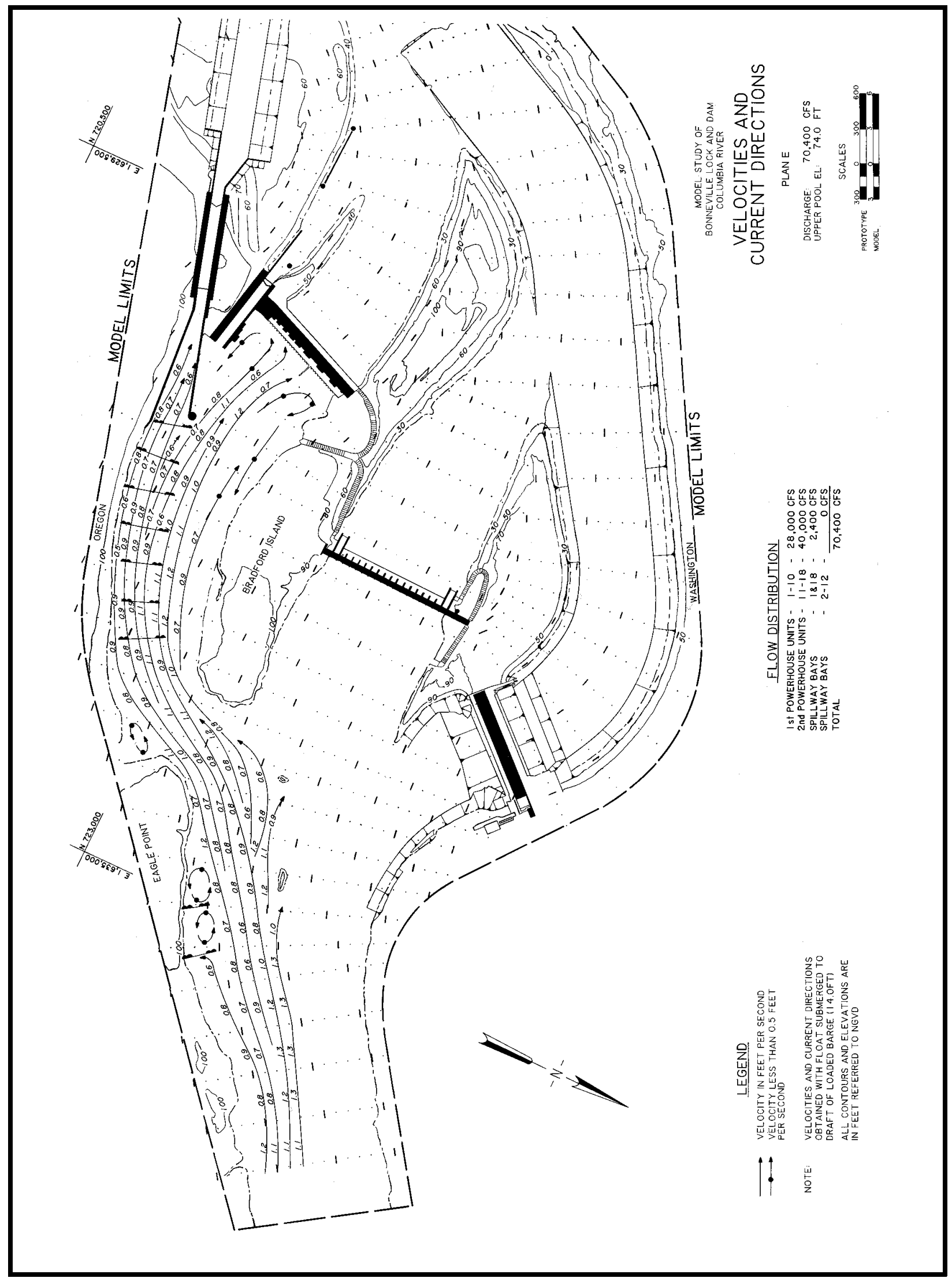

Plate 68 


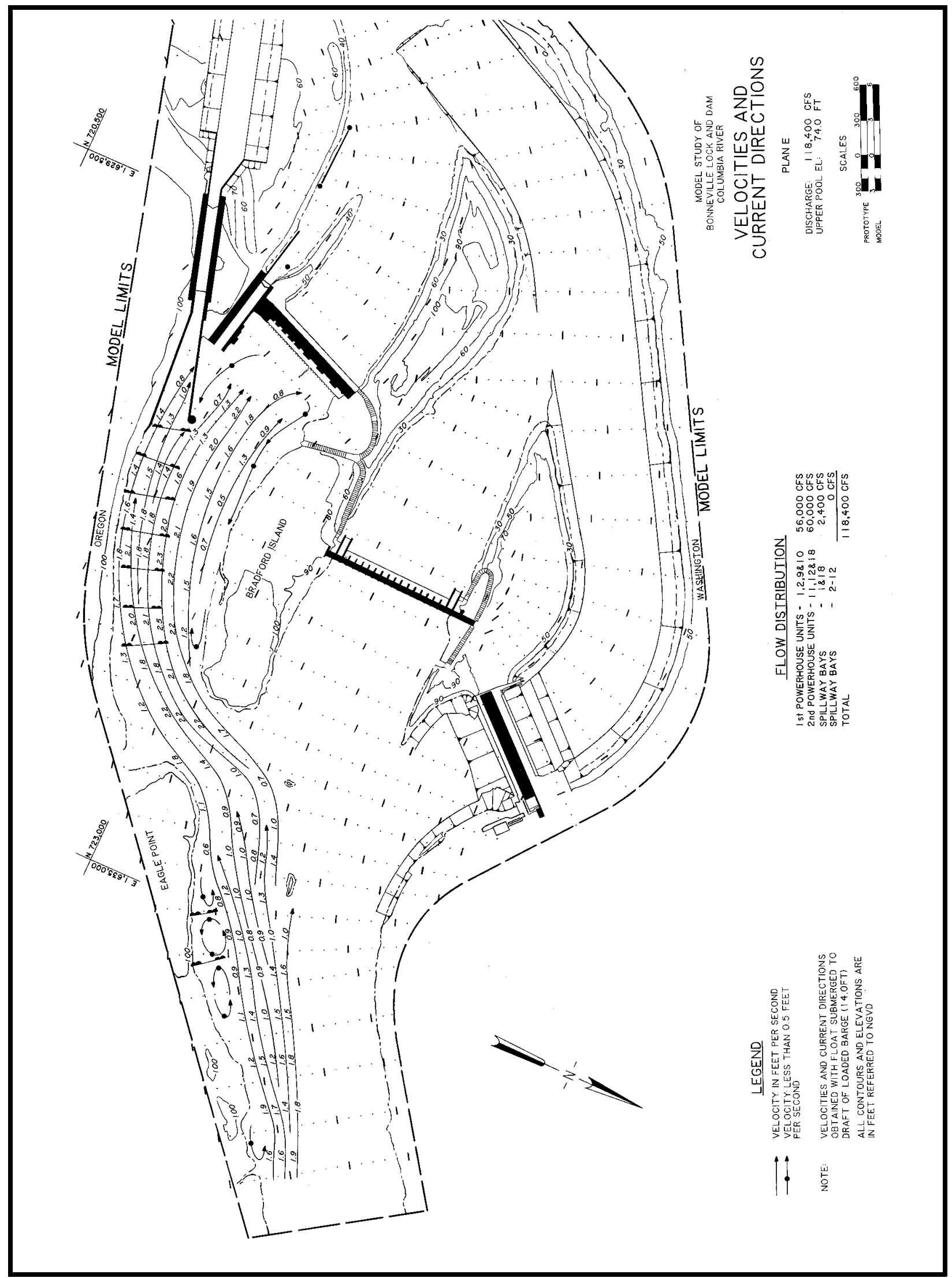

Plate 69 


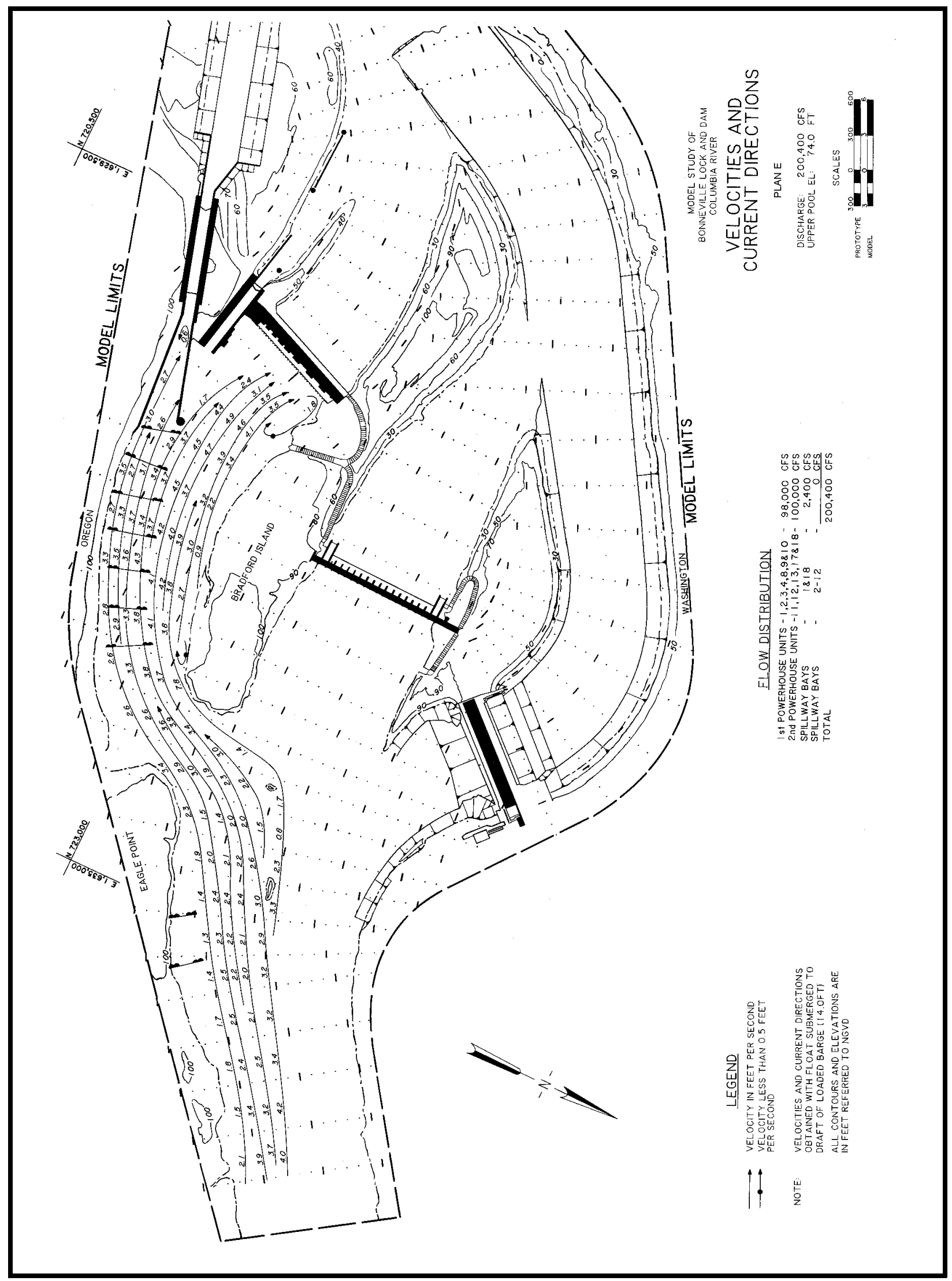

Plate 70 


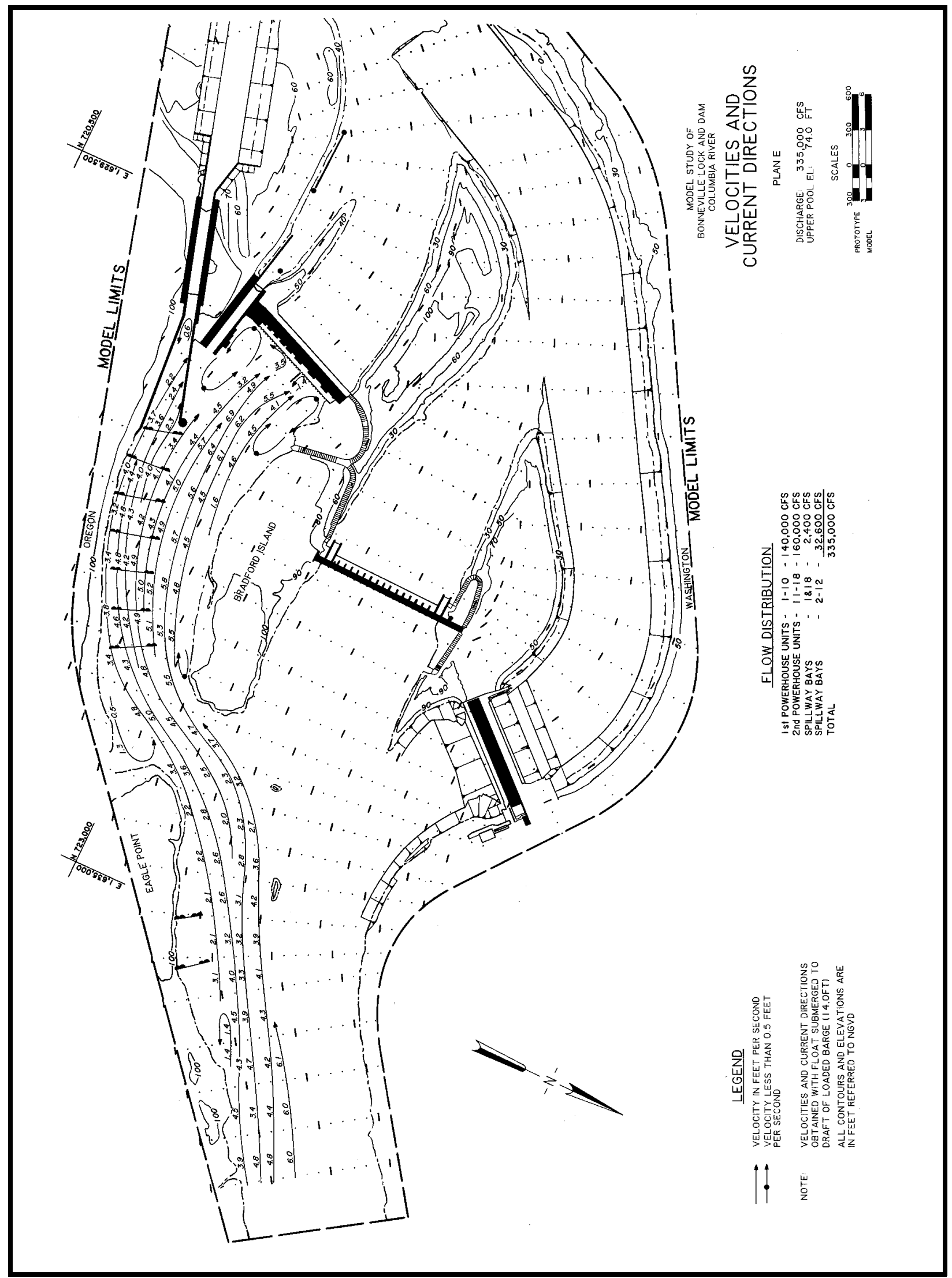

Plate 71 


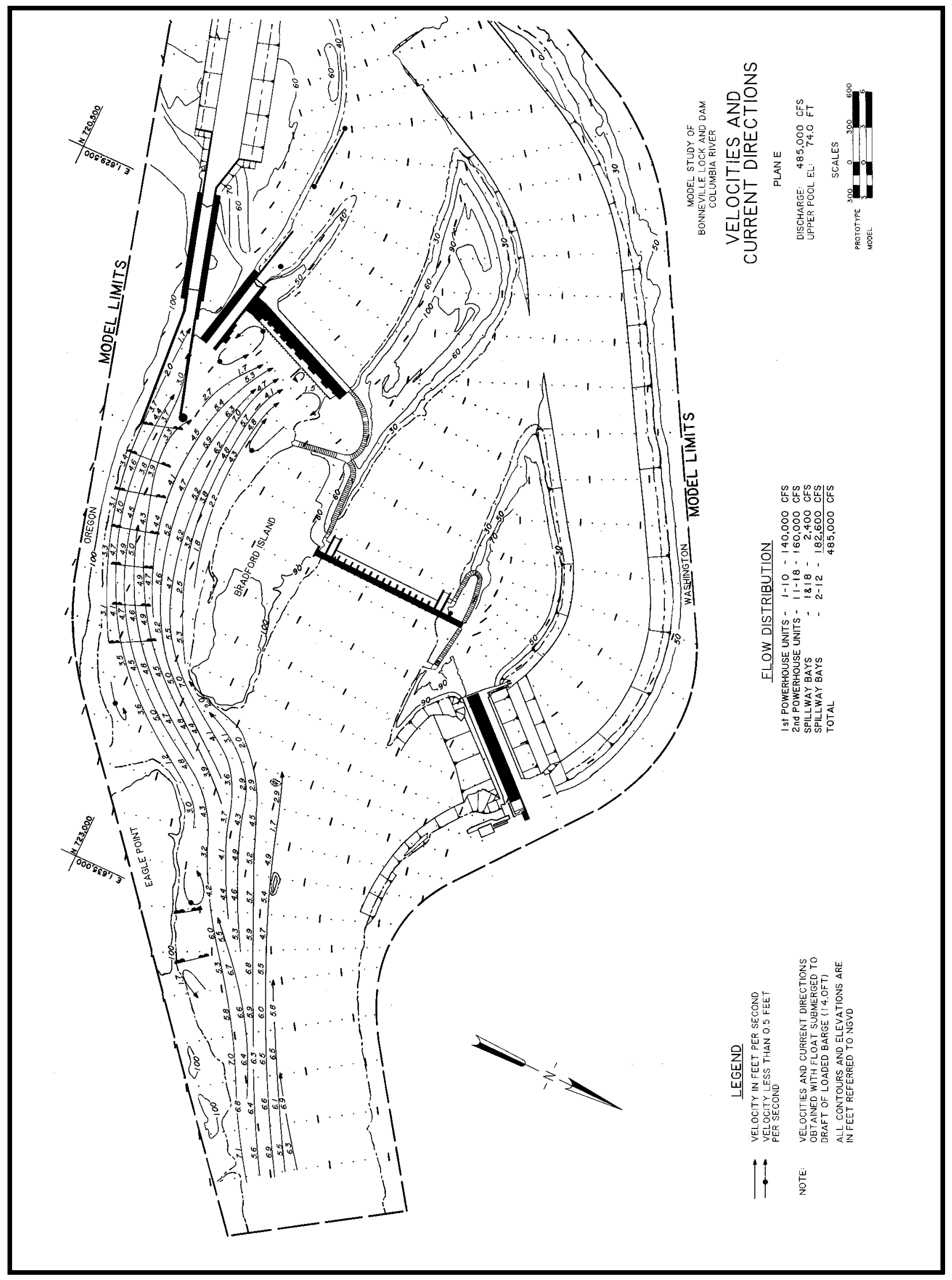

Plate 72 


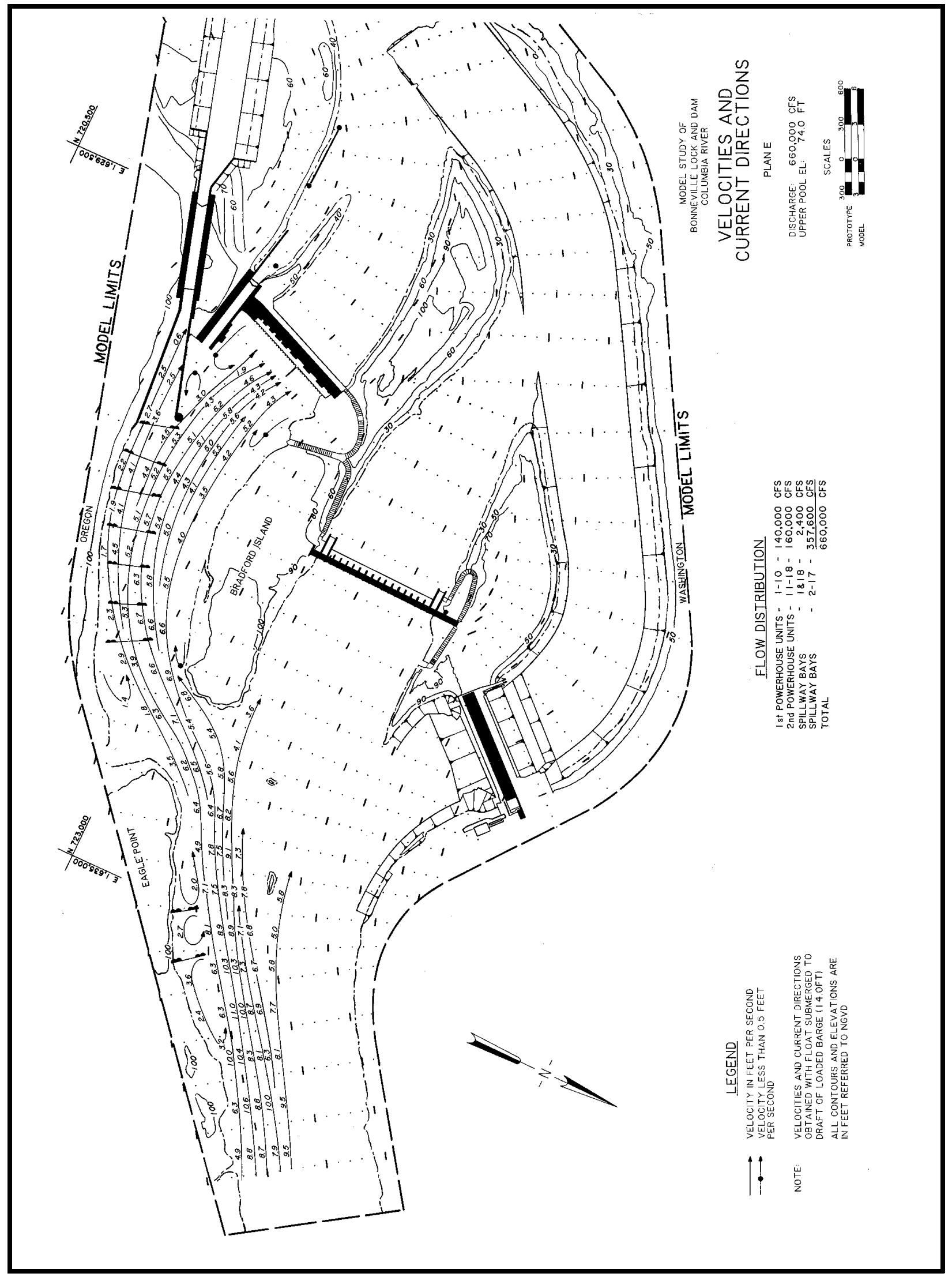

Plate 73 


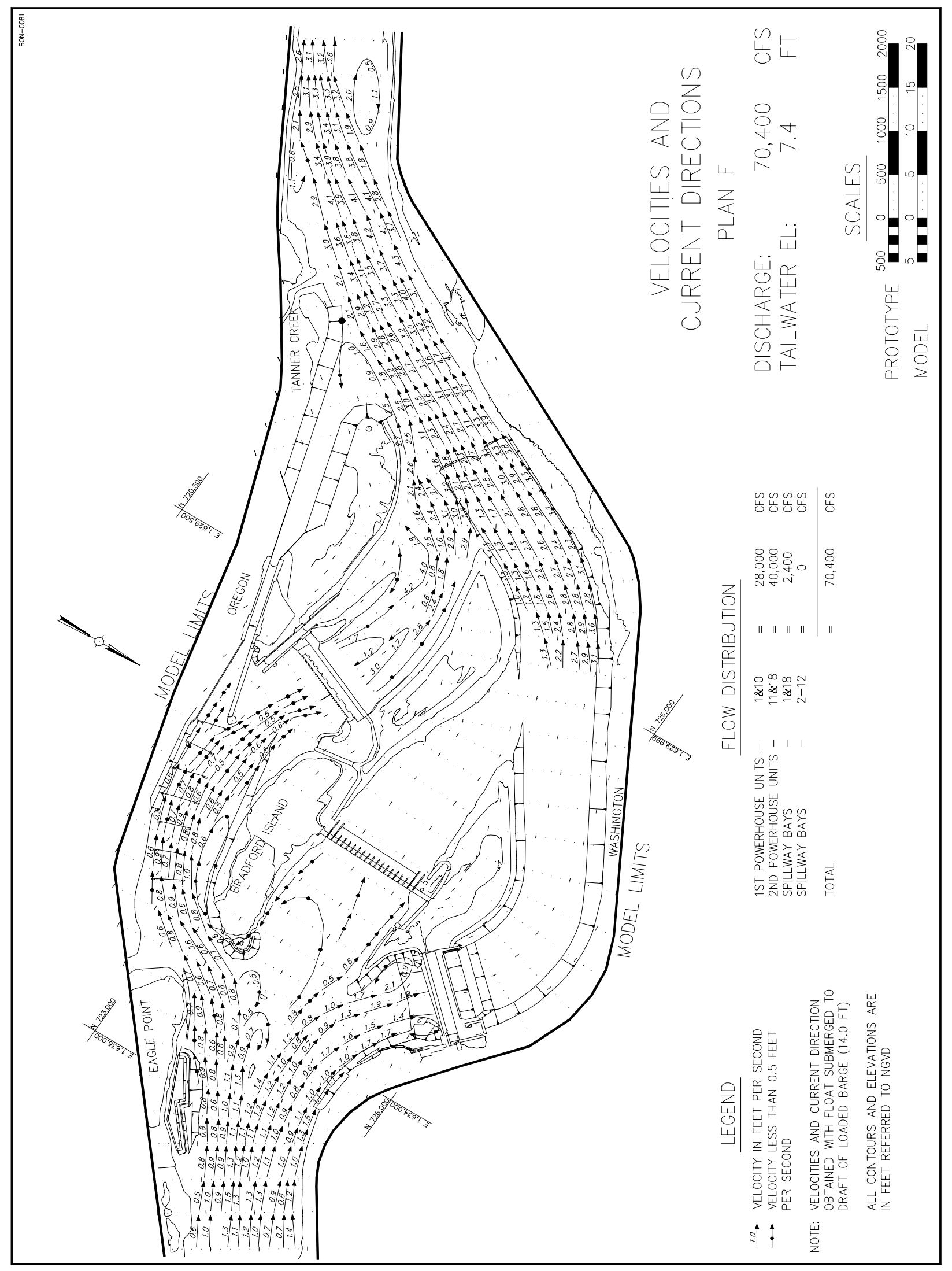

Plate 74 


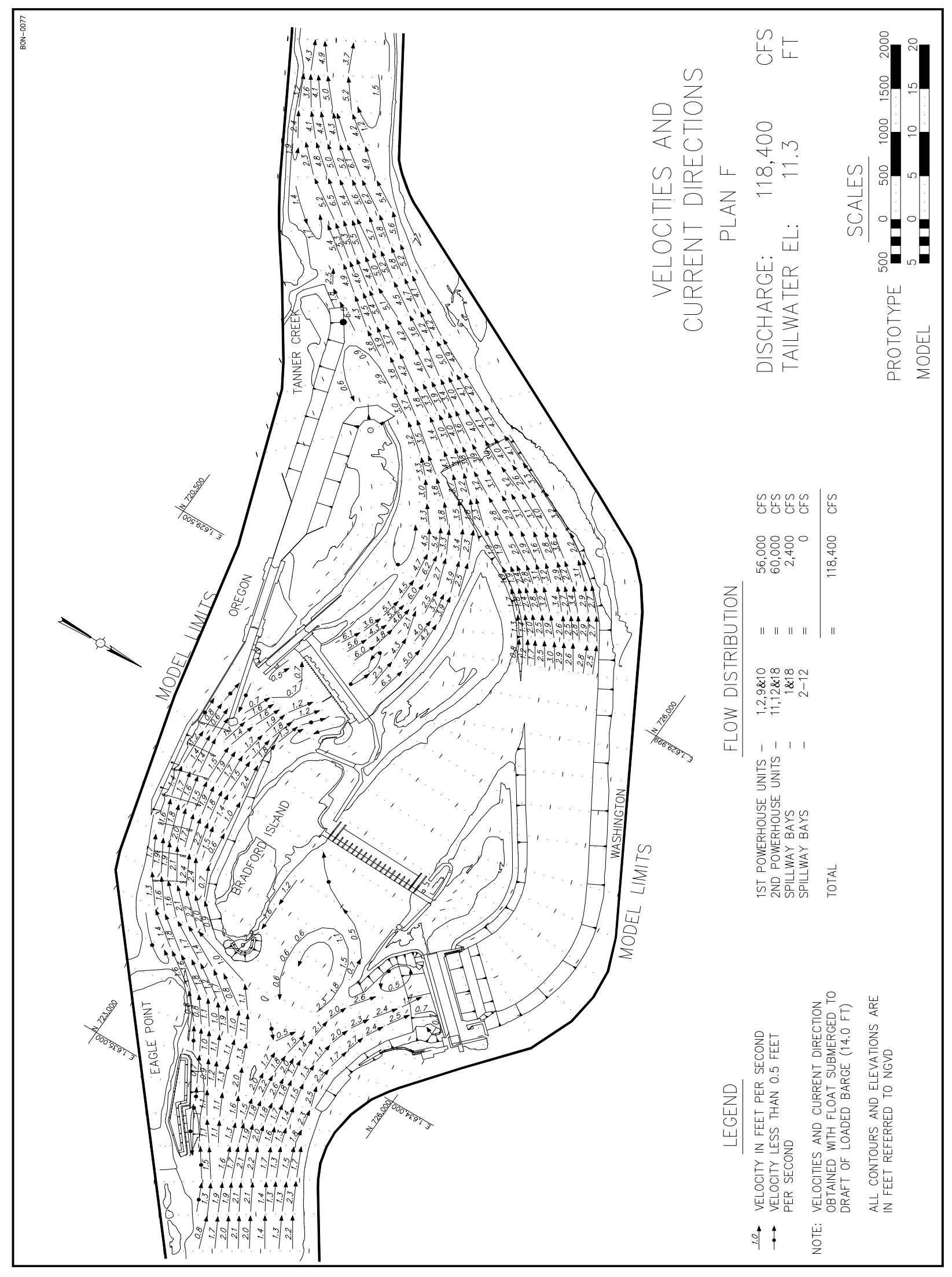

Plate 75 


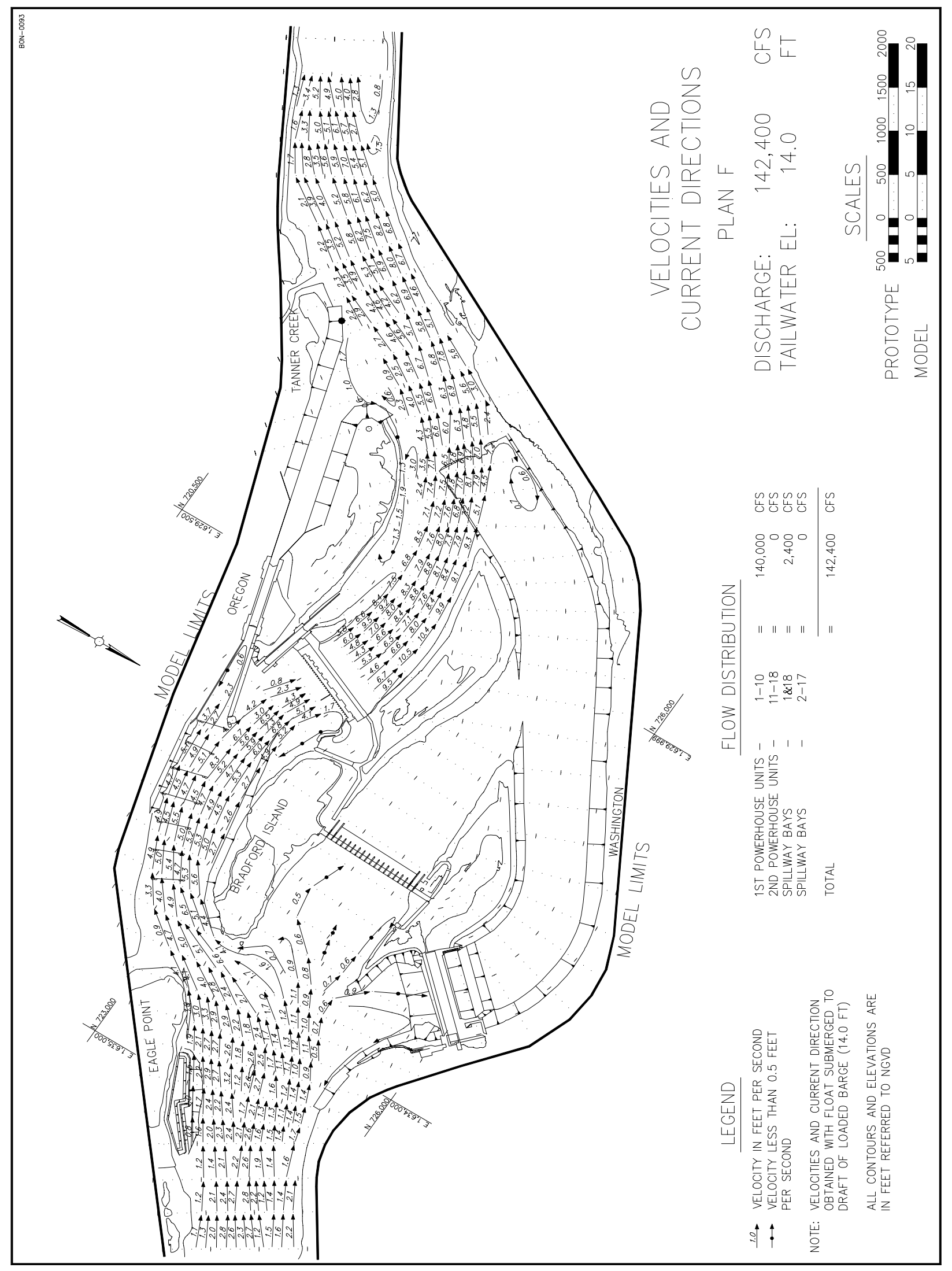

Plate 76 


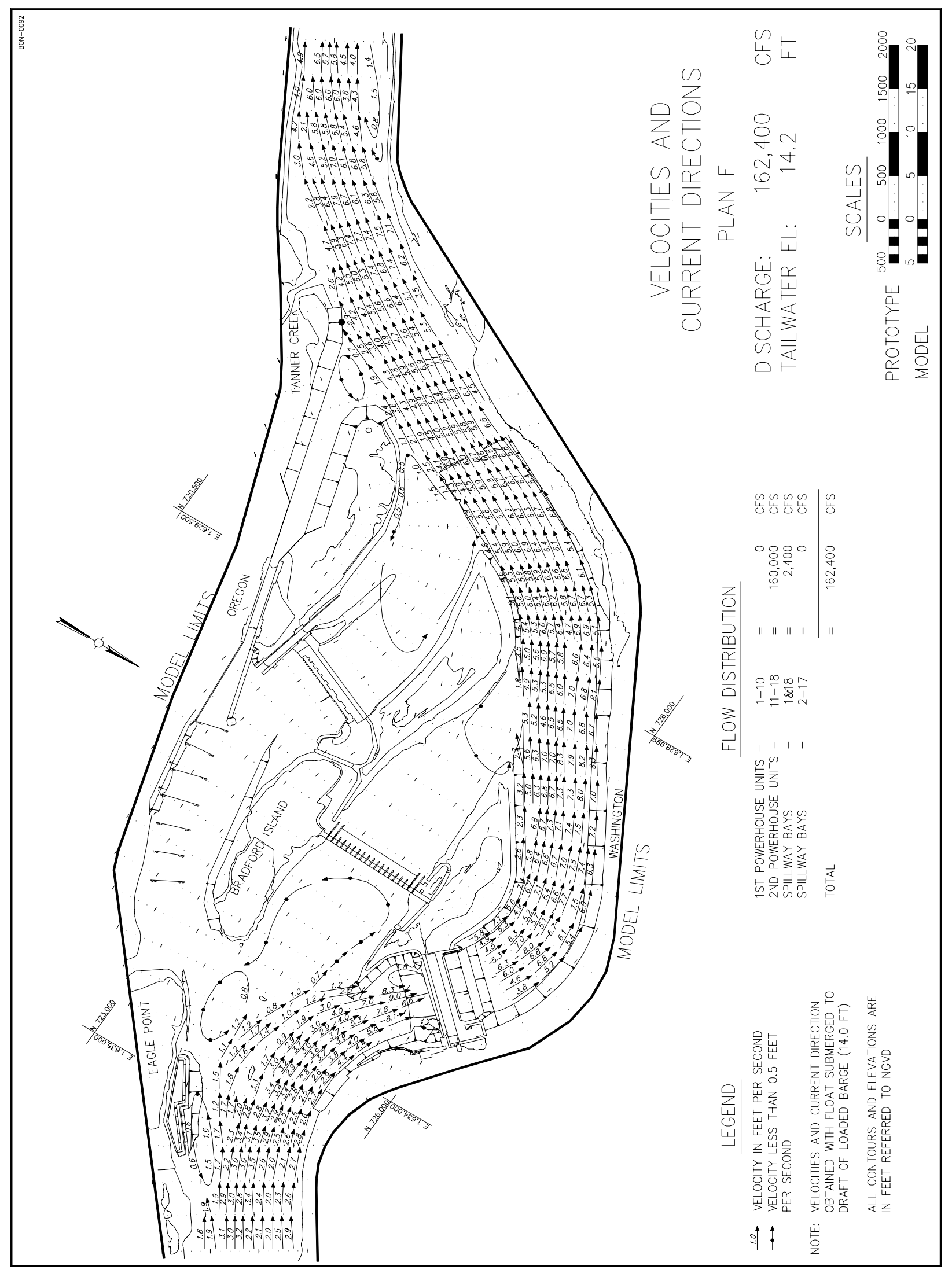

Plate 77 


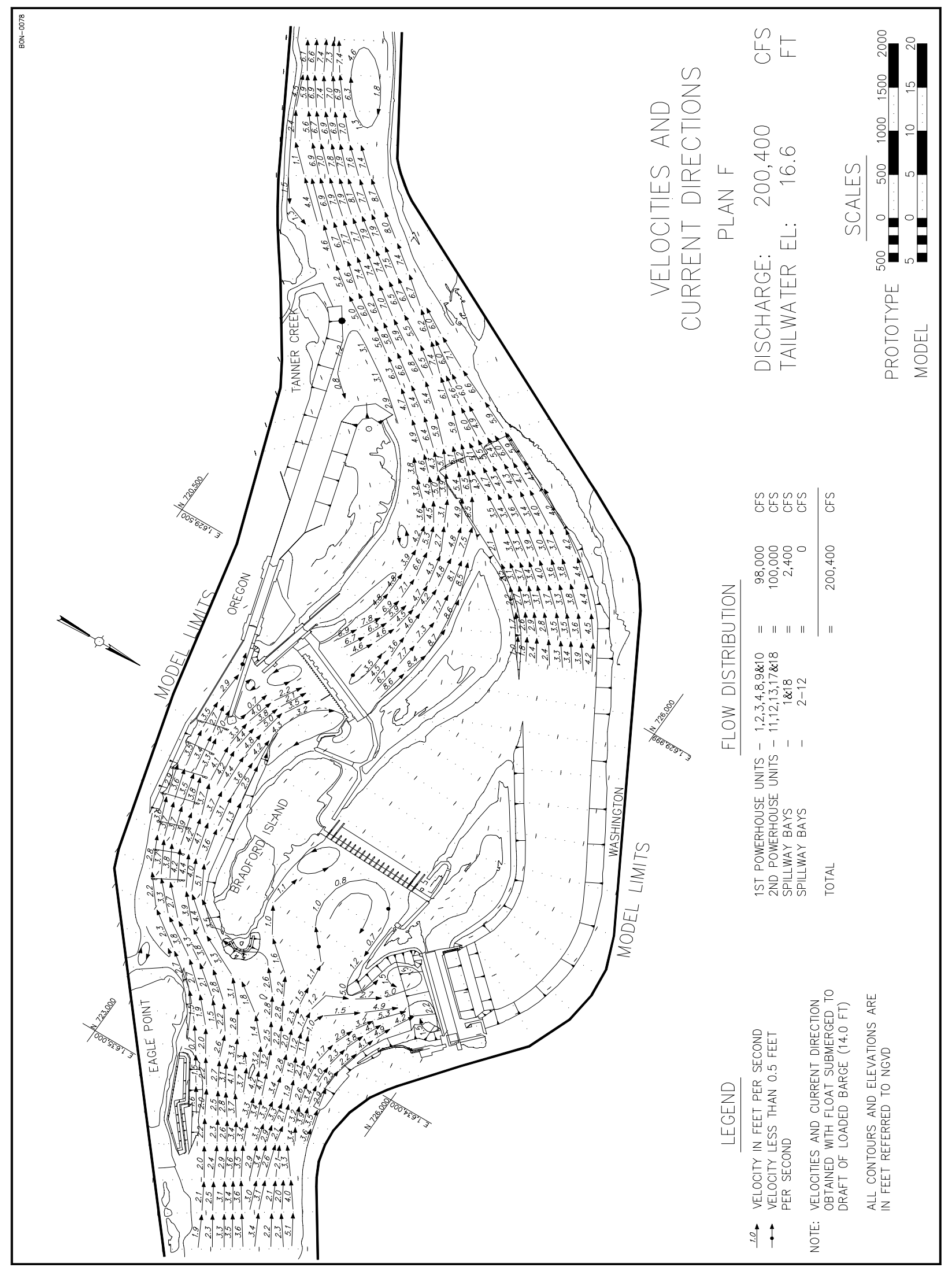

Plate 78 


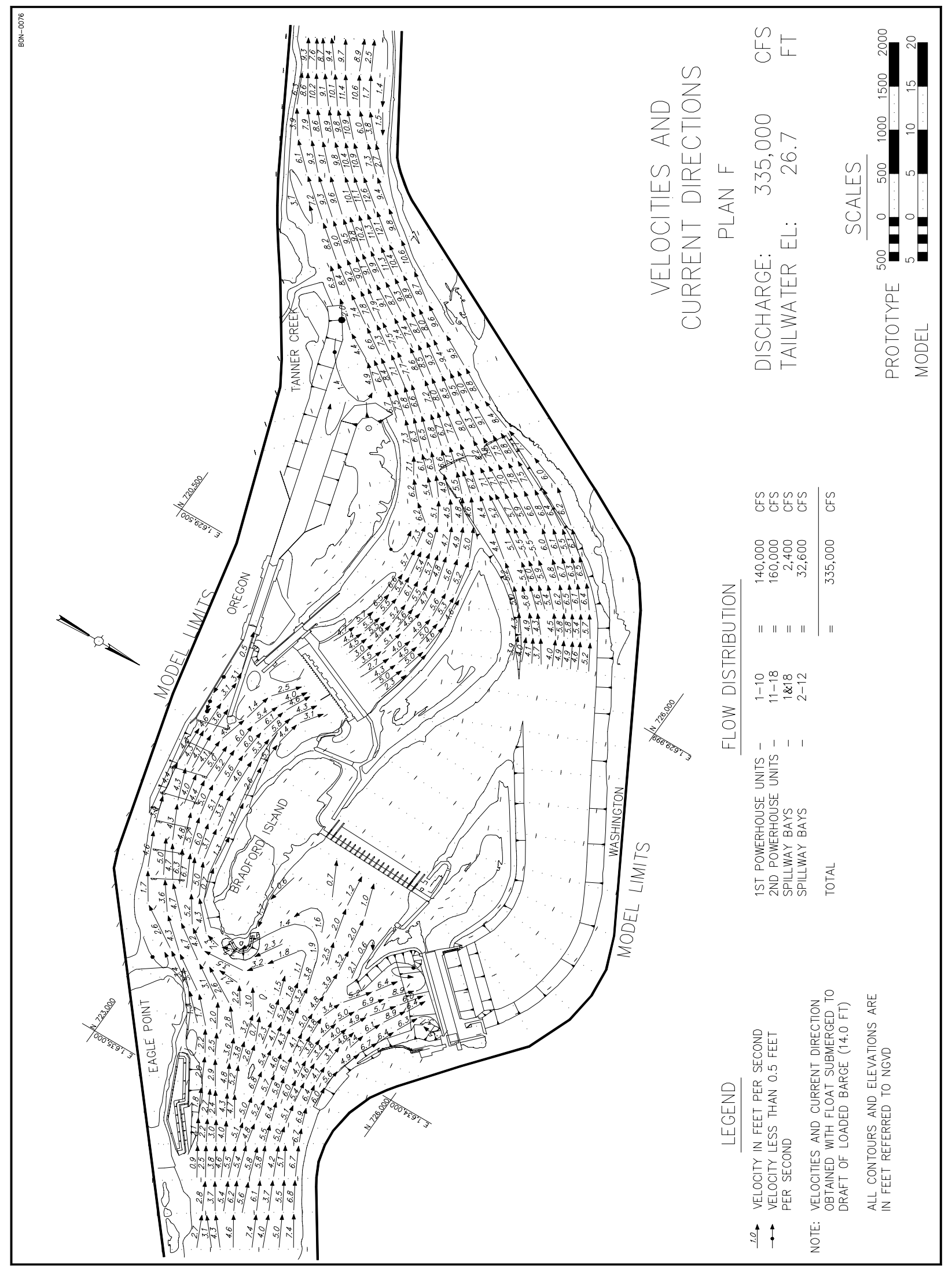

Plate 79 


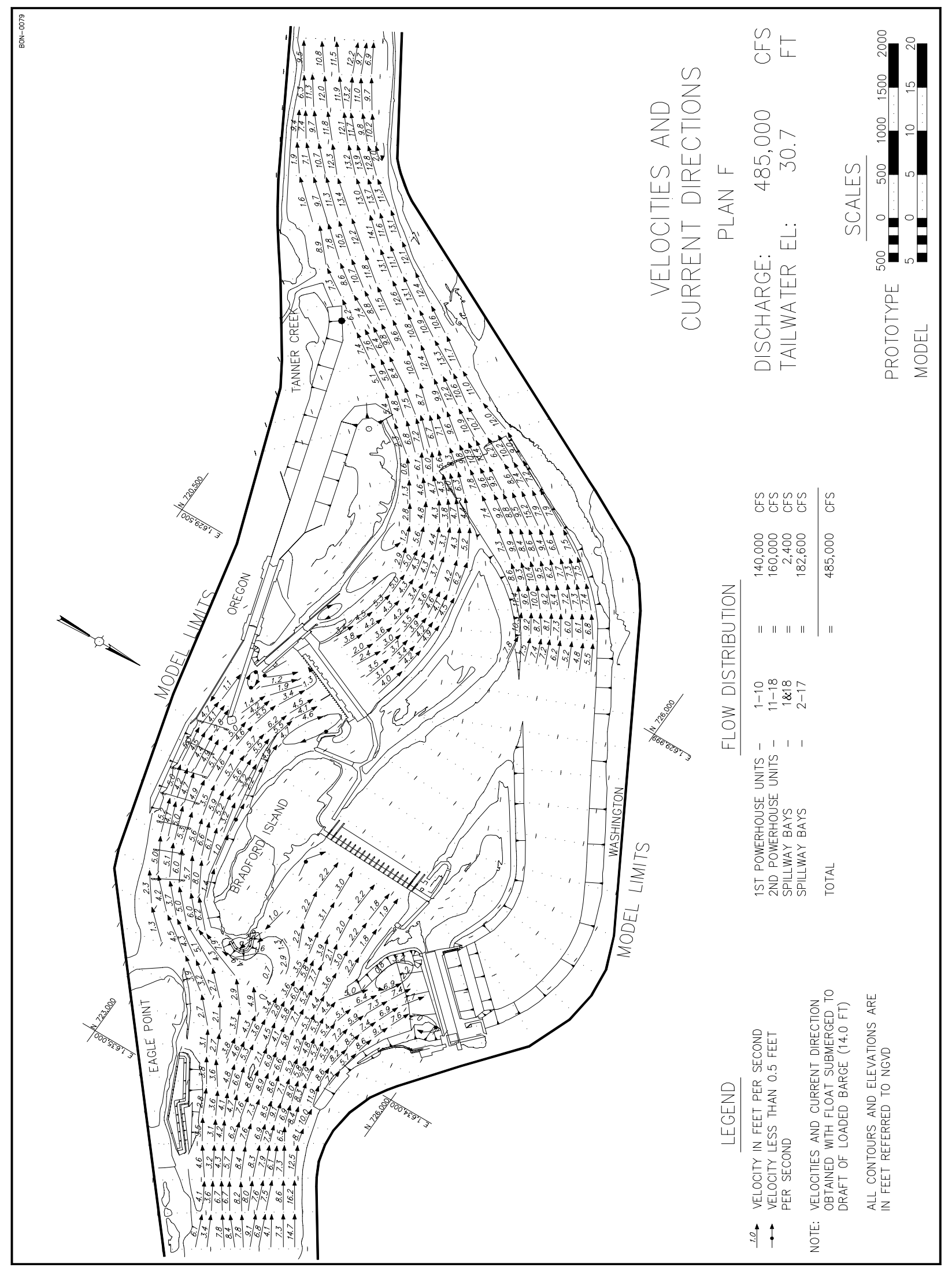

Plate 80 


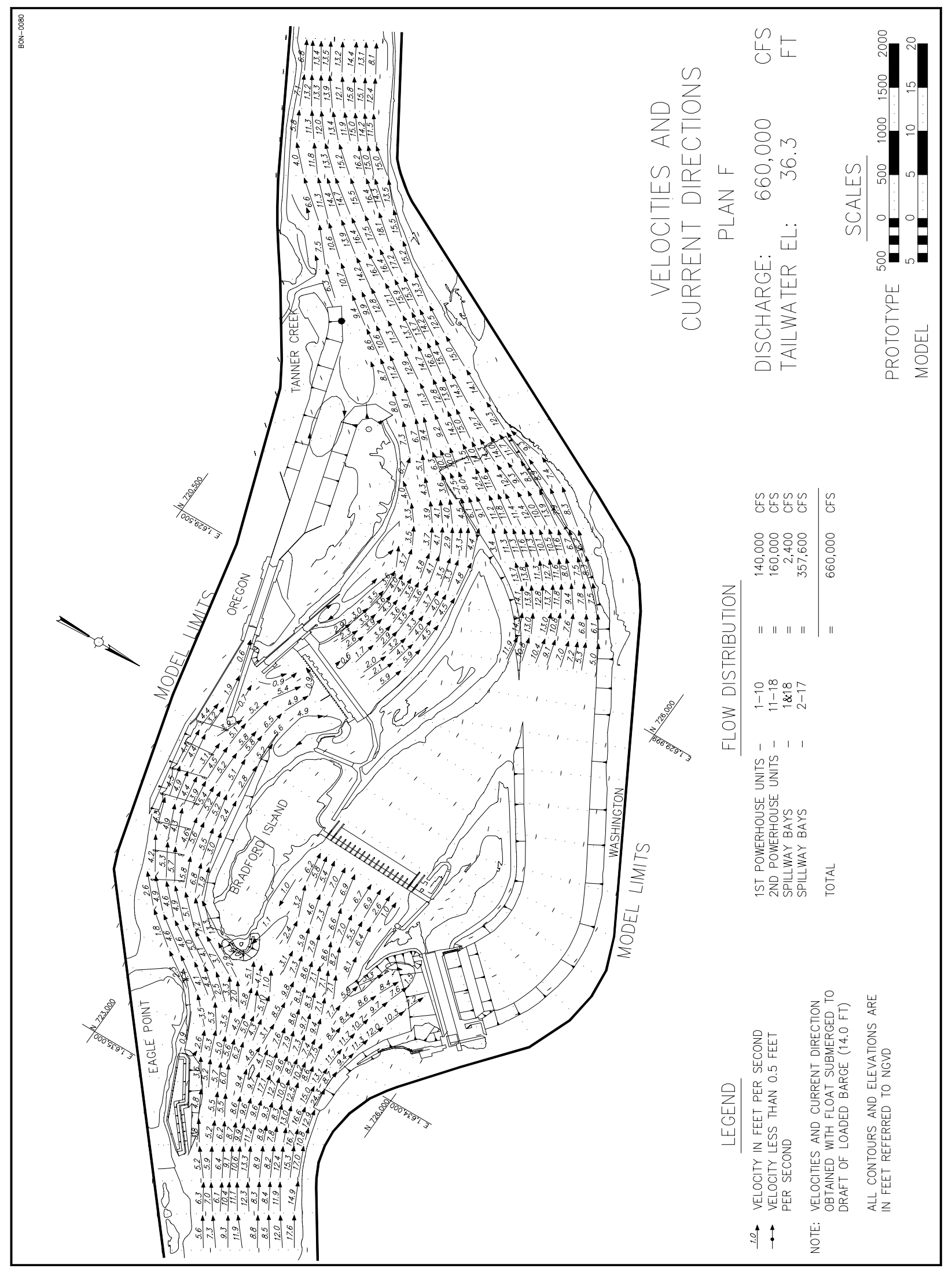

Plate 81 


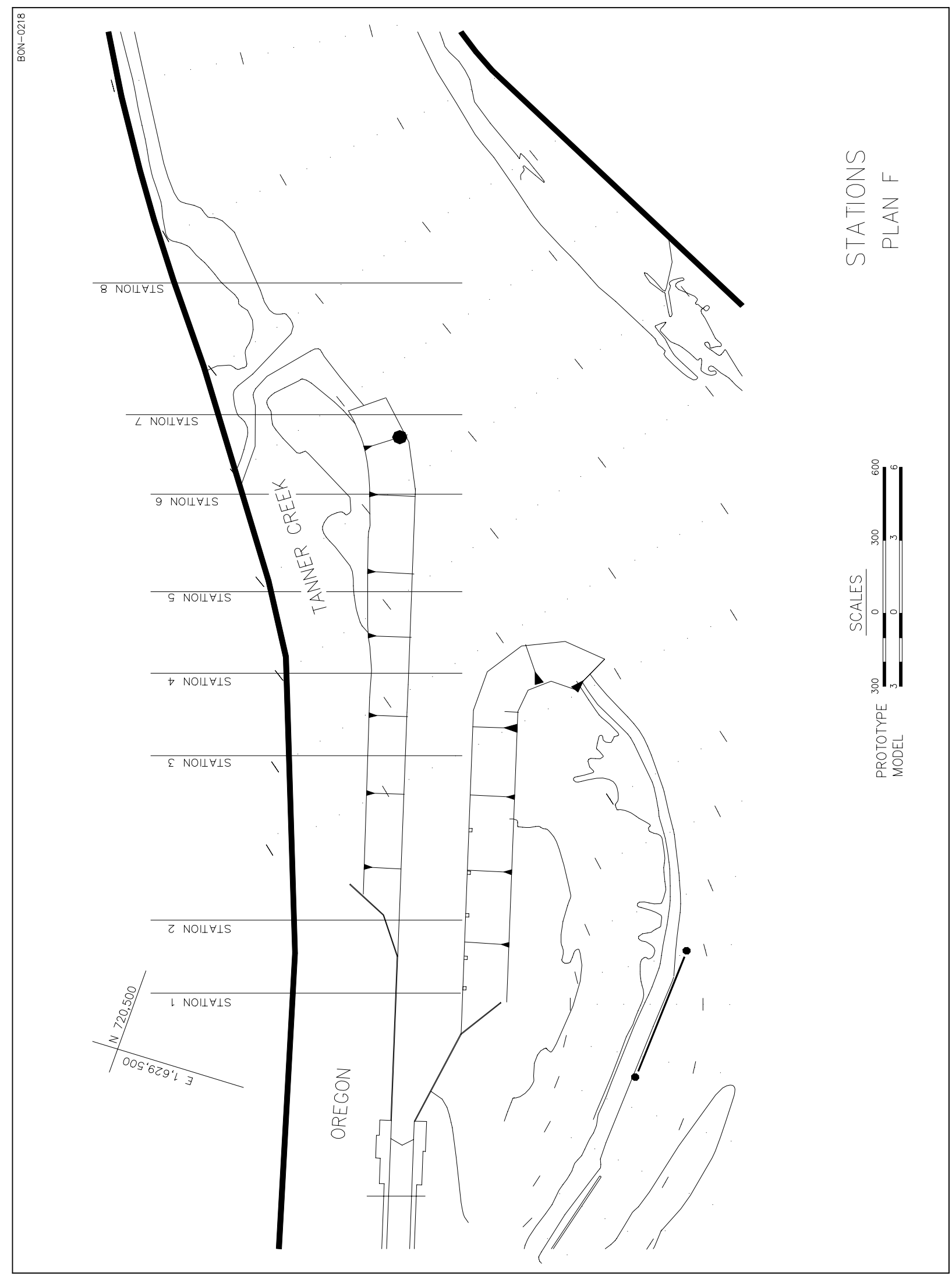

Plate 82 


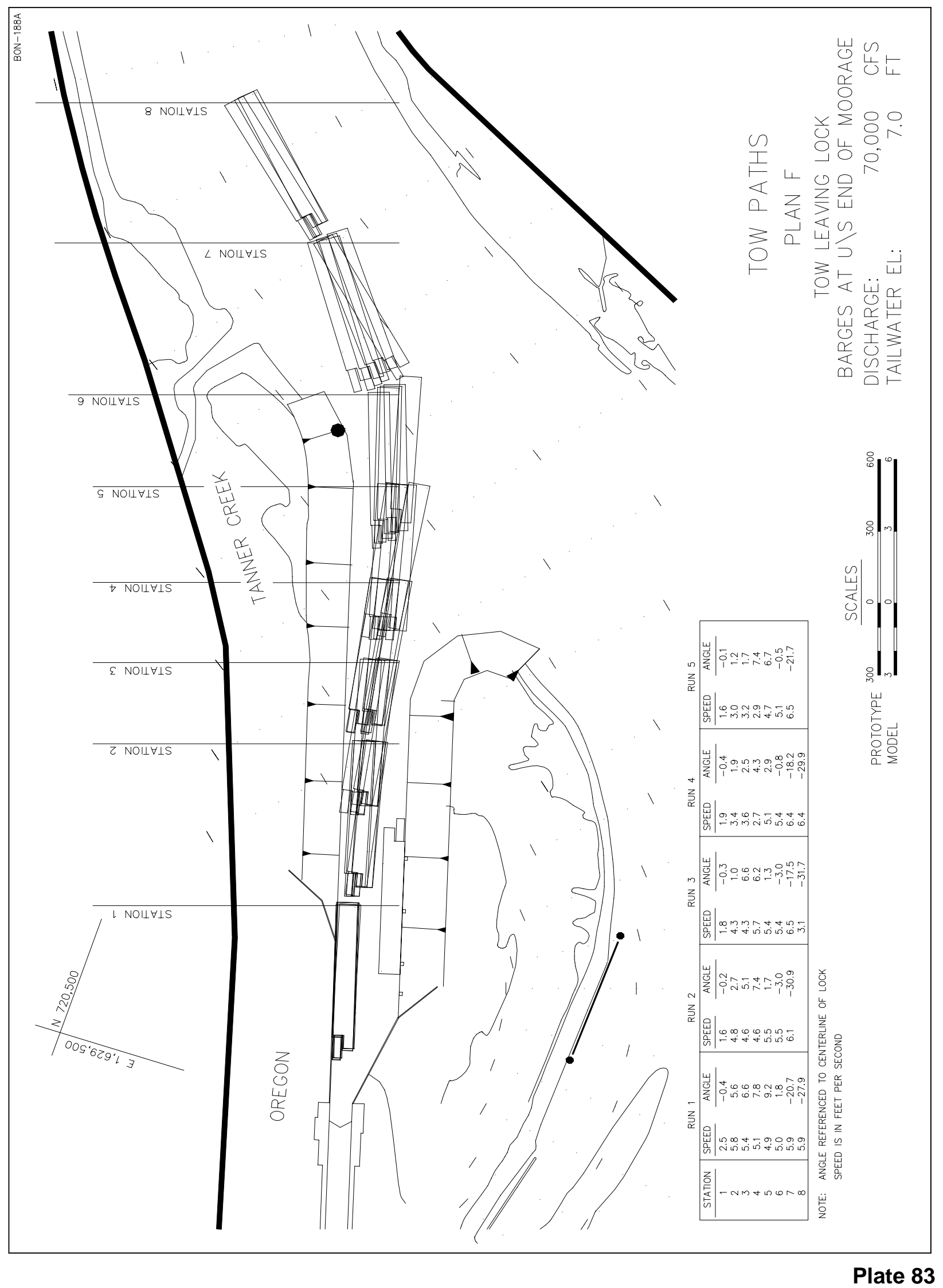




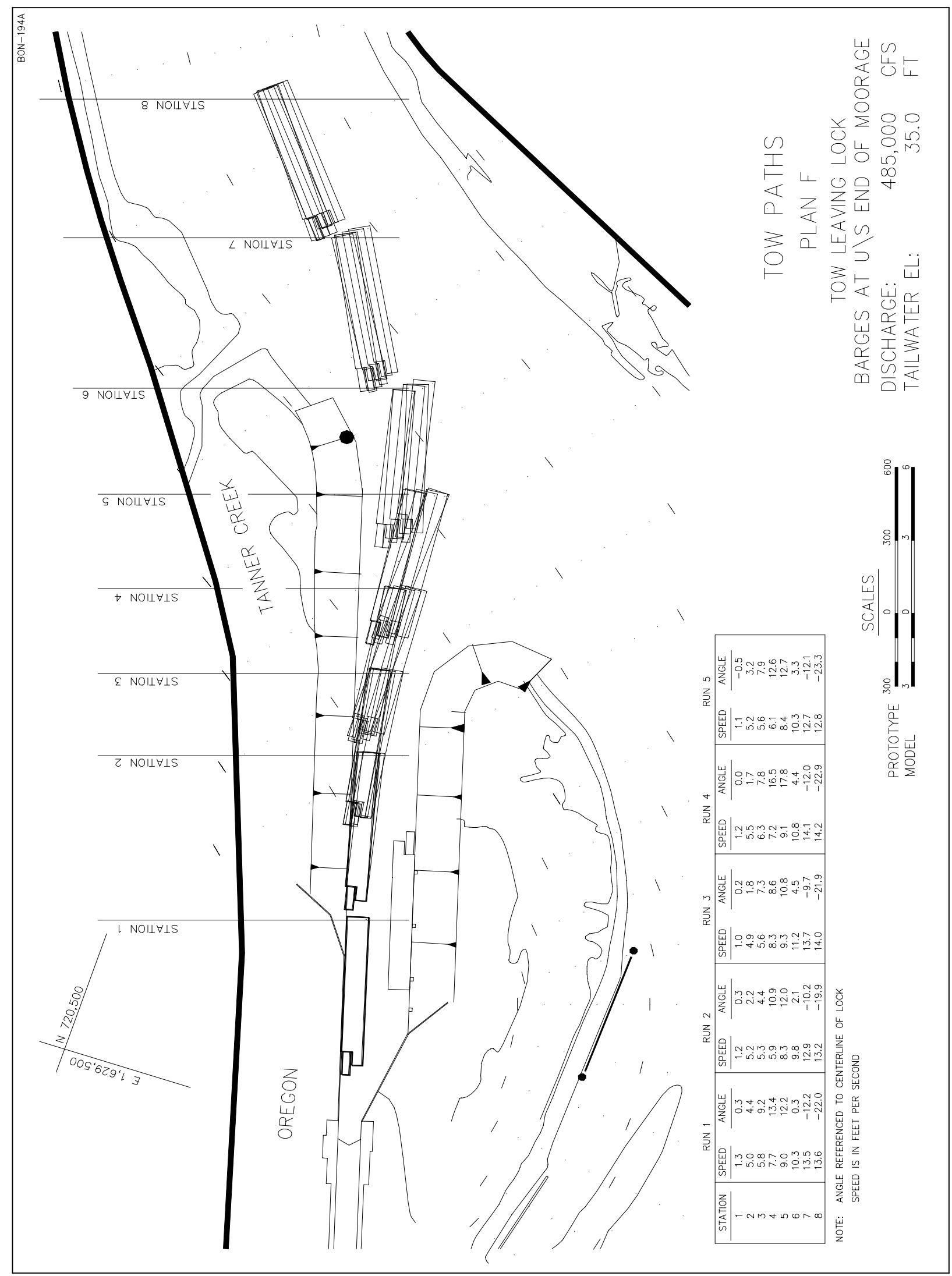

Plate 84 


$$
y^{x}
$$




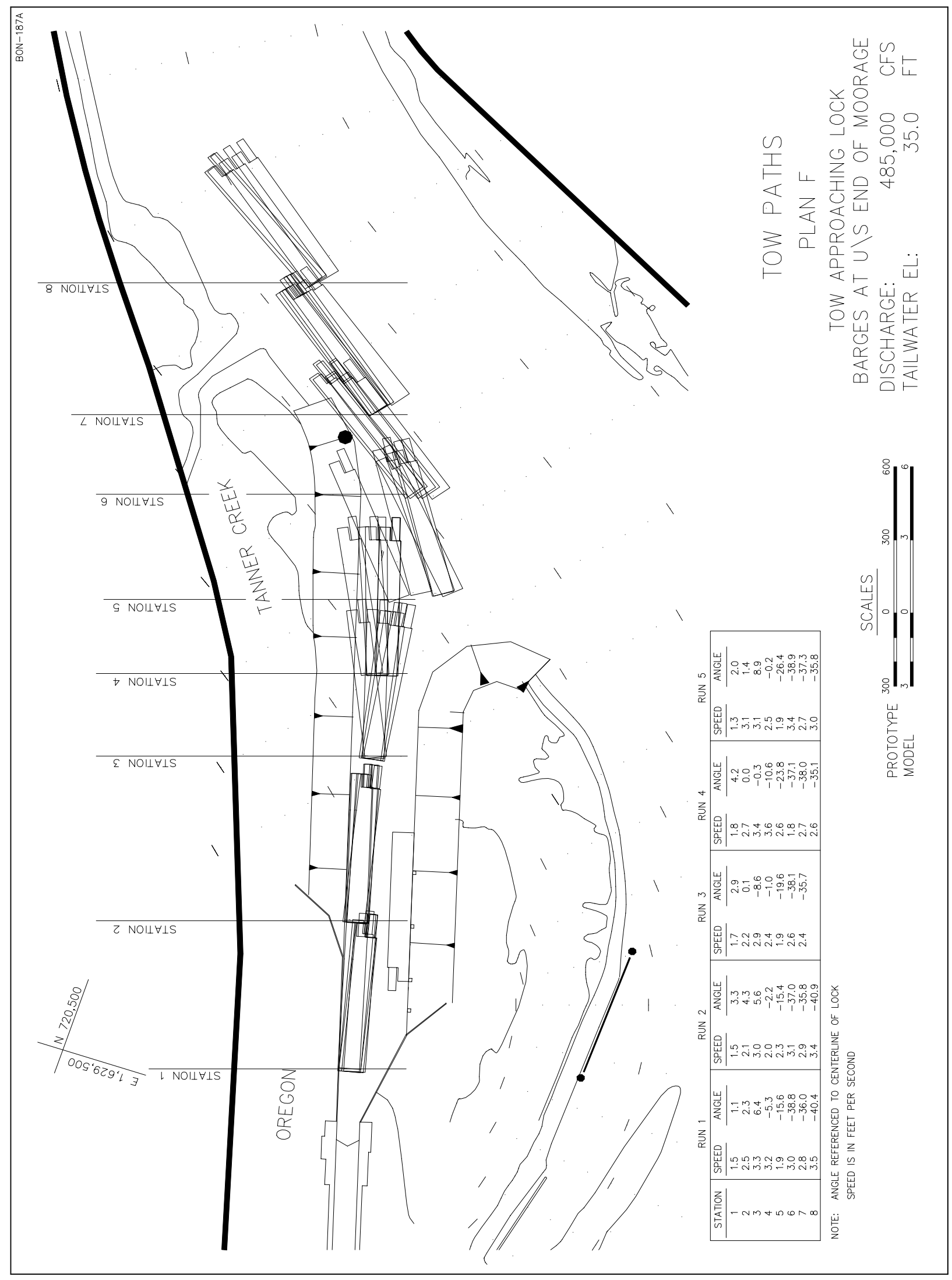

Plate 86 


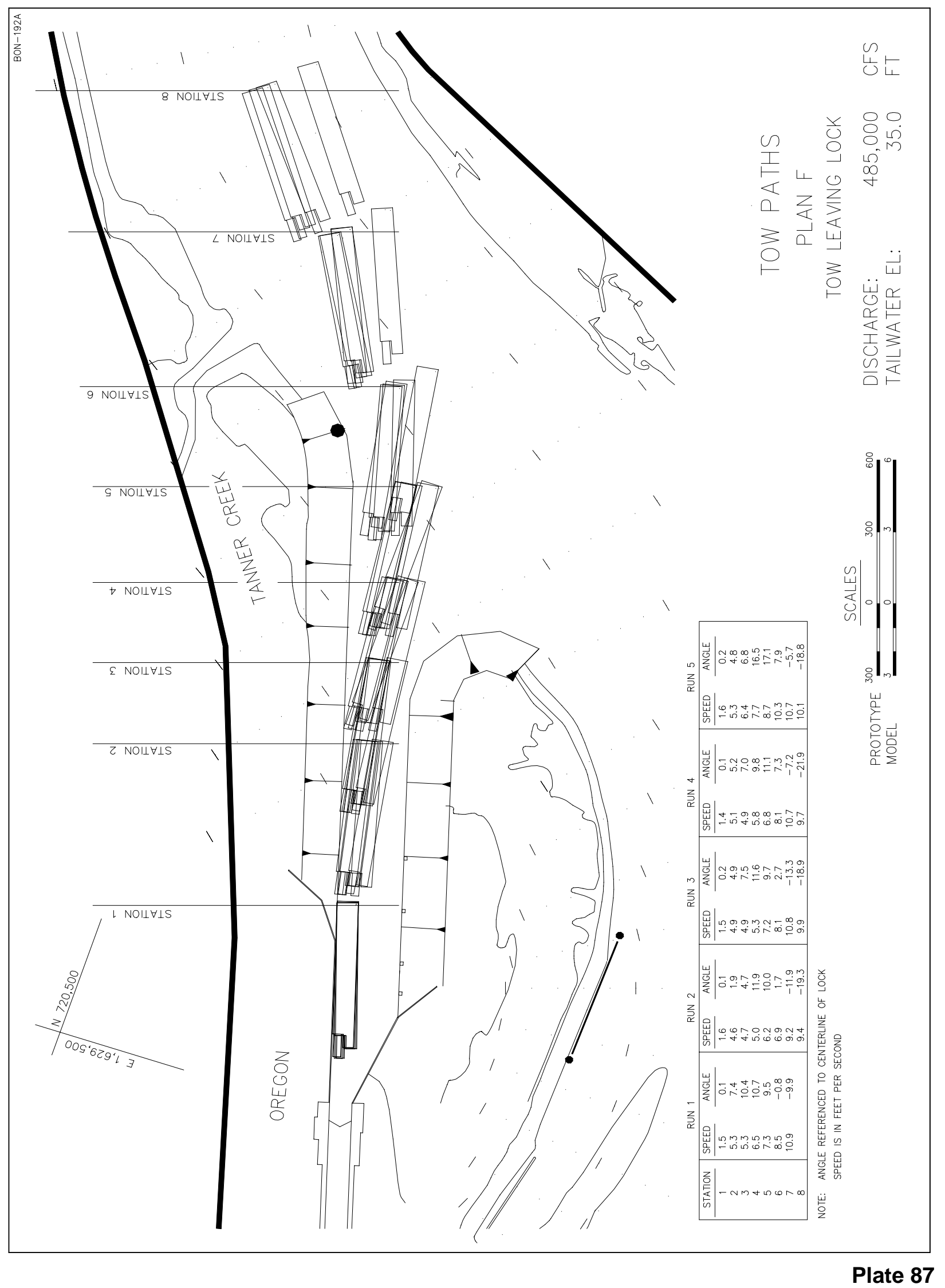




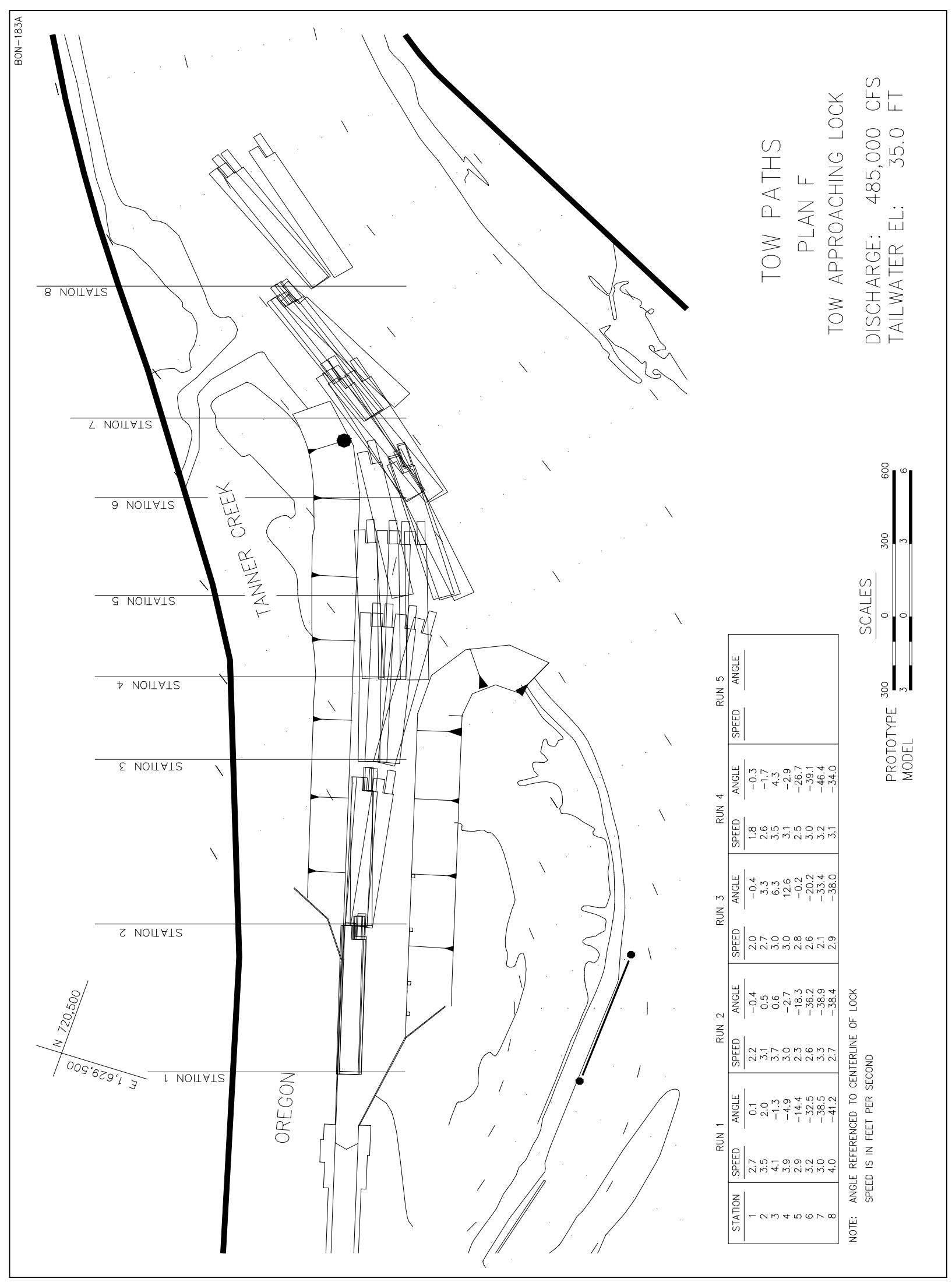

Plate 88 


$$
H^{\prime}
$$




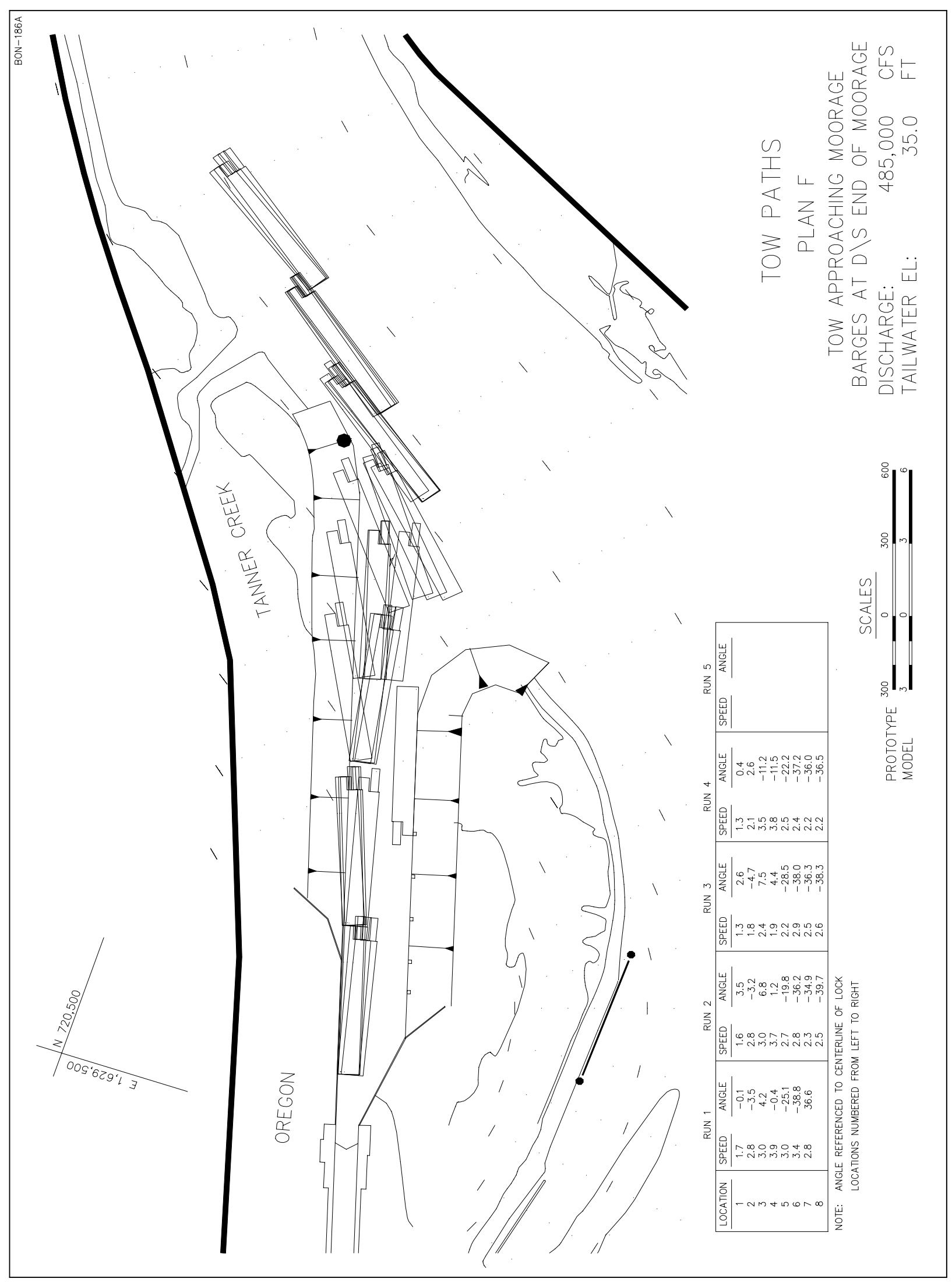

Plate 90 


$$
y^{\prime}
$$




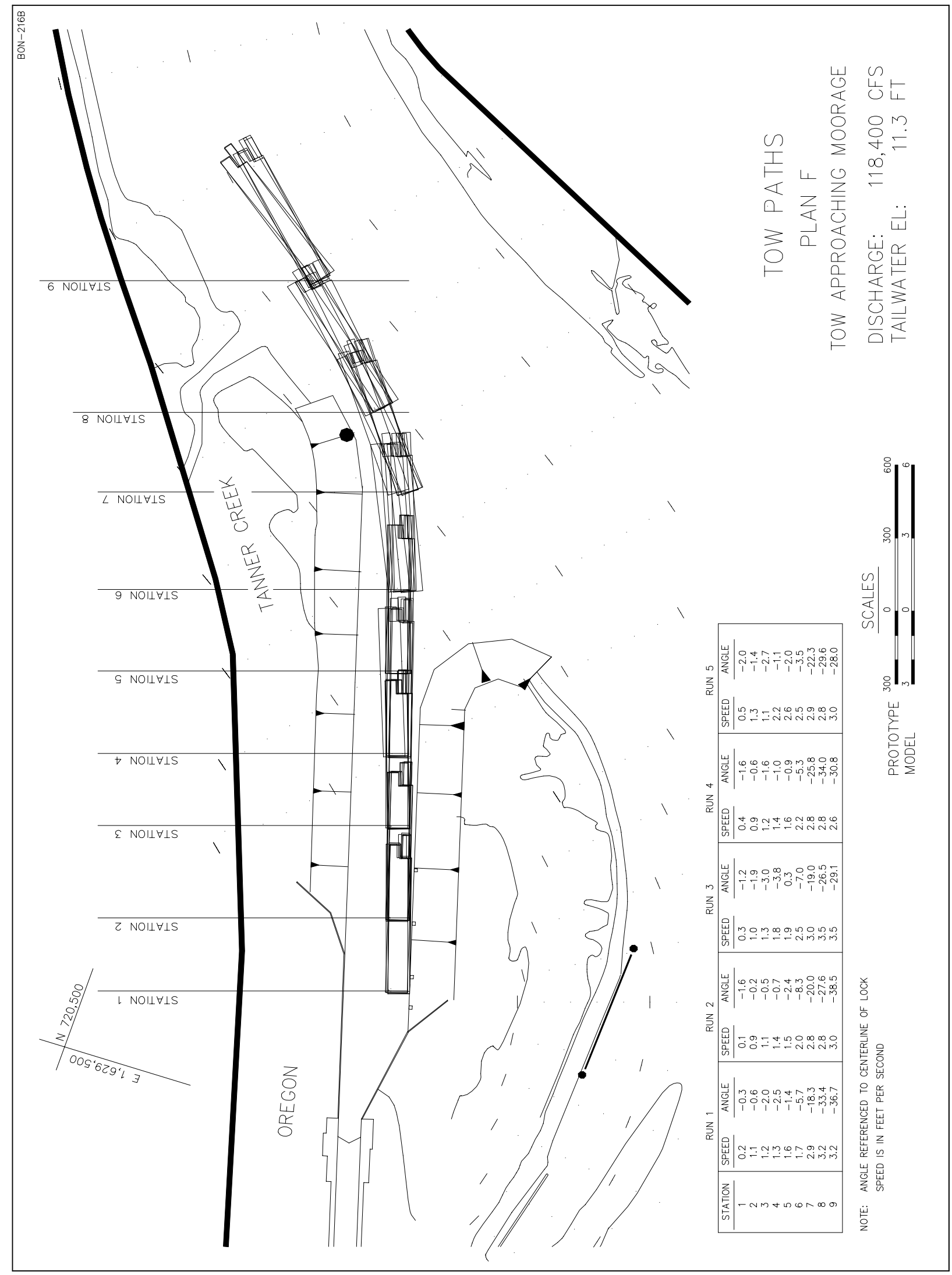

Plate 92 


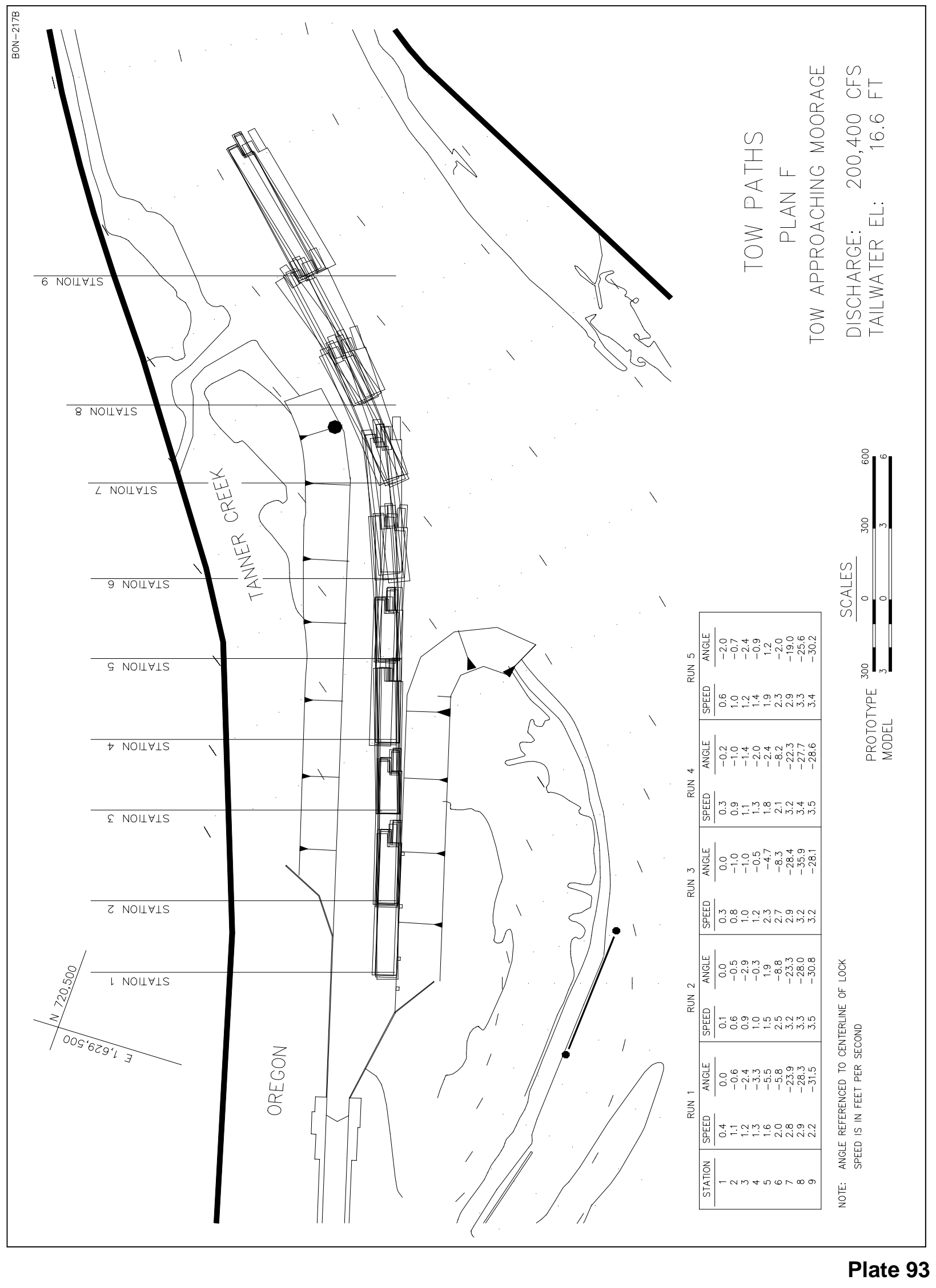




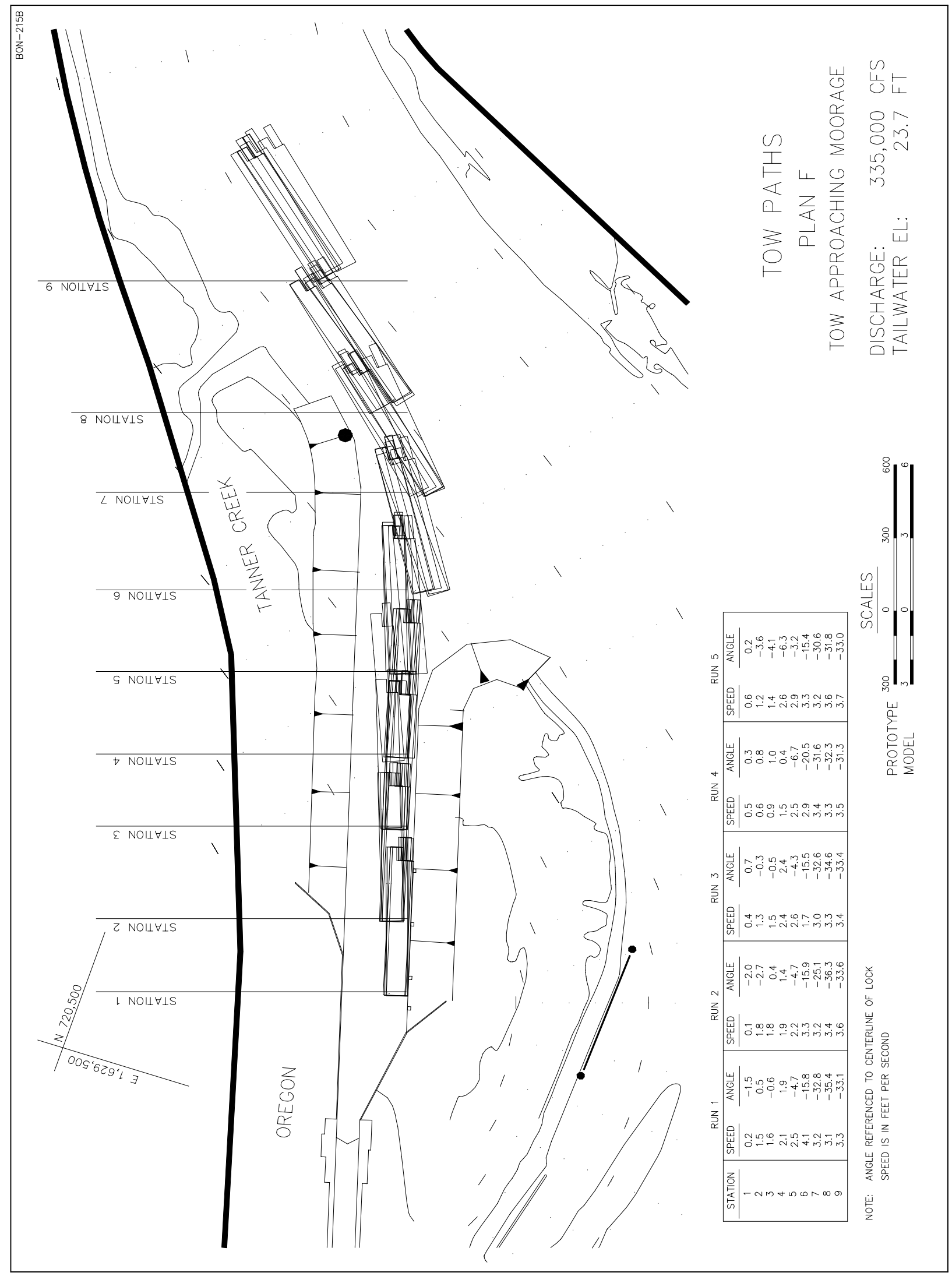

Plate 94 


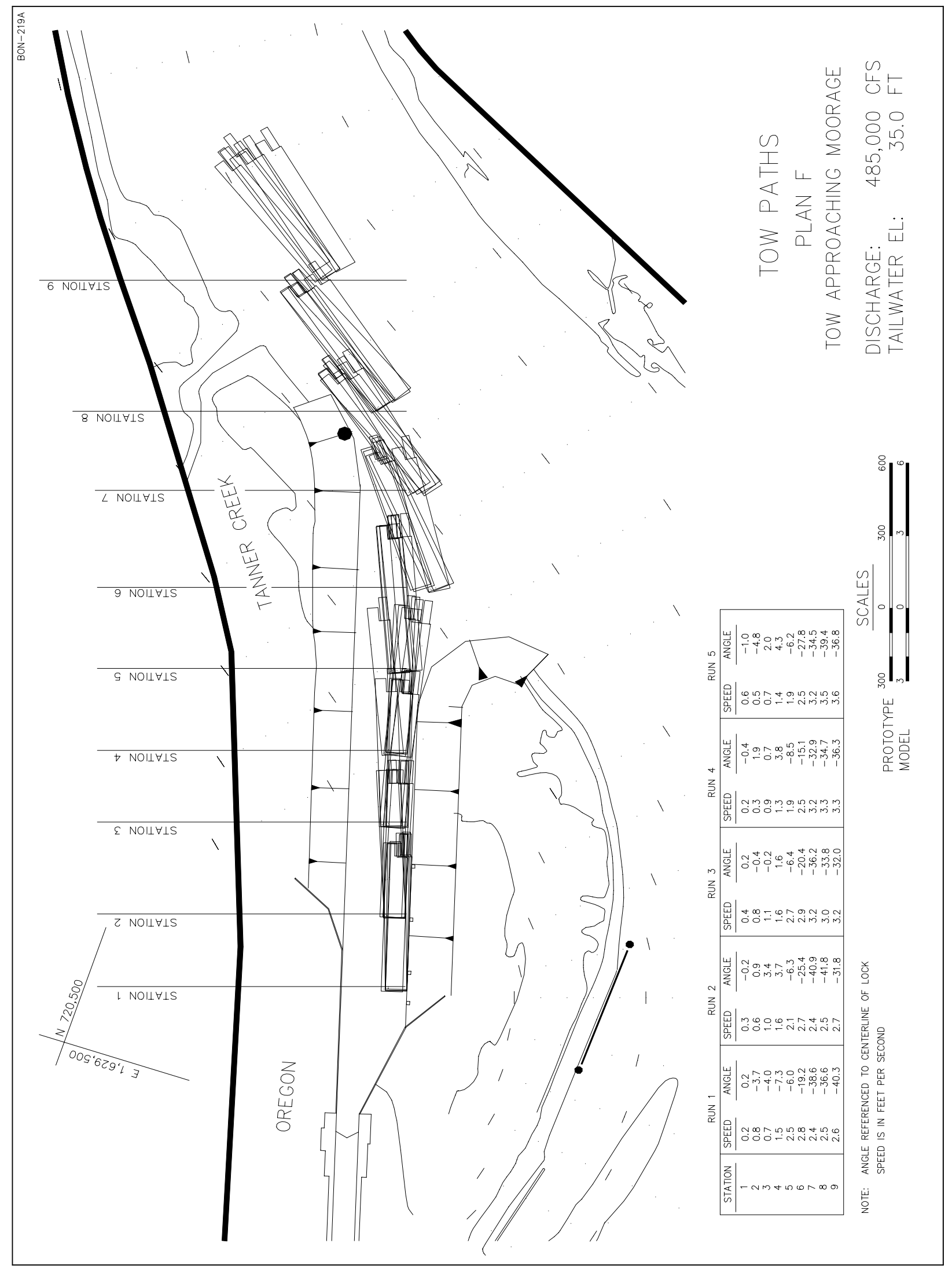

Plate 95 


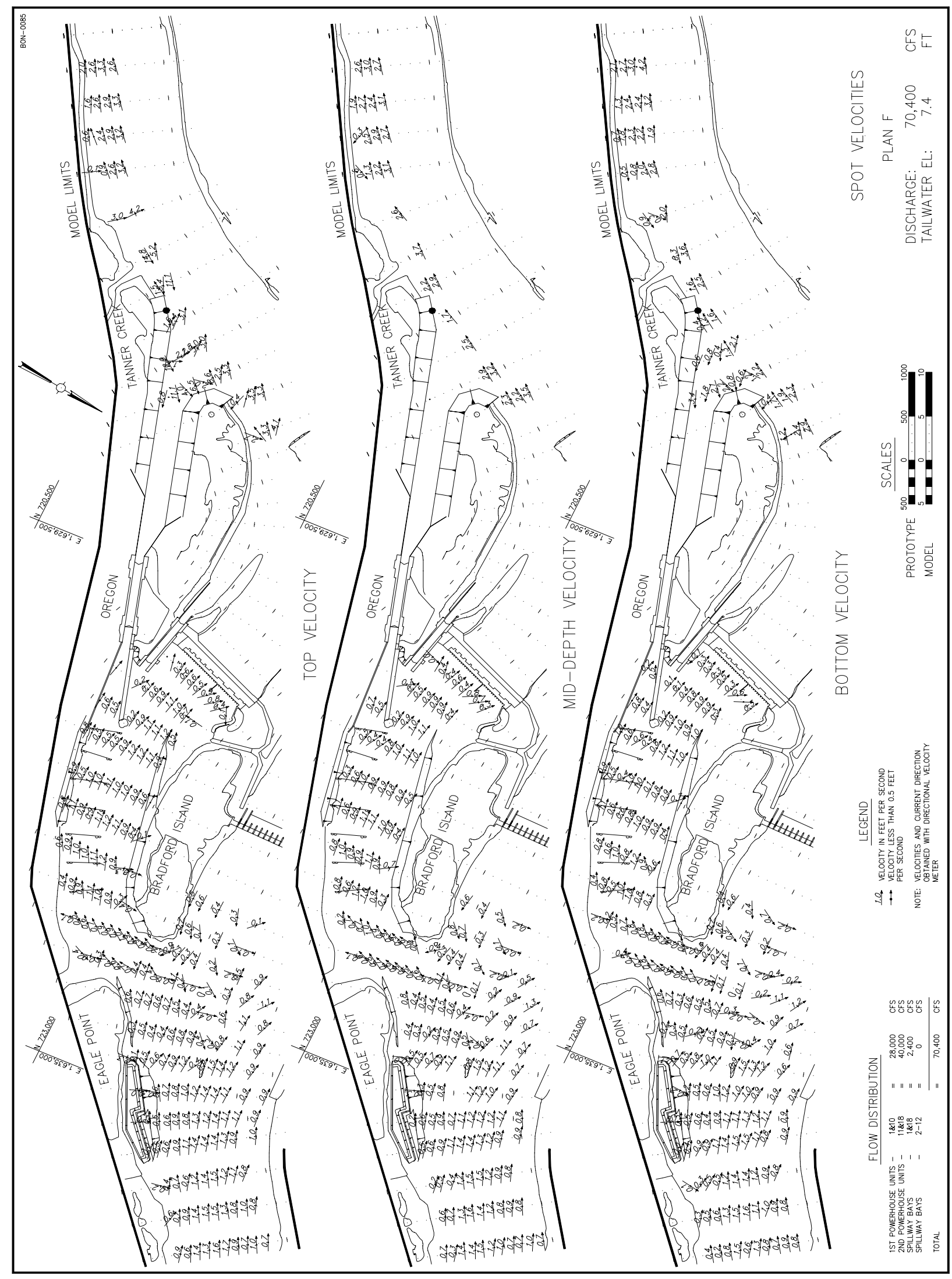

Plate 96 


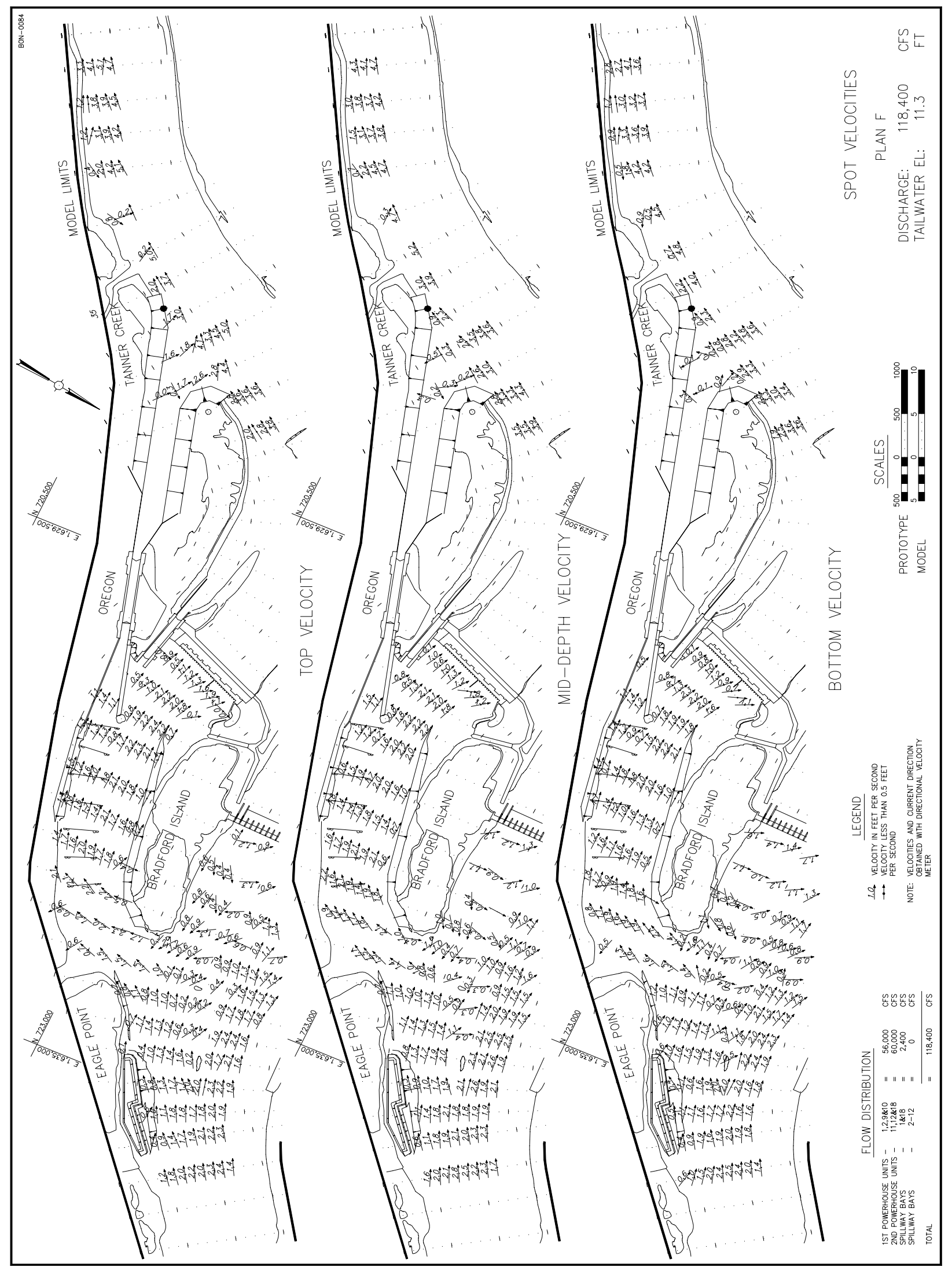

Plate 97 


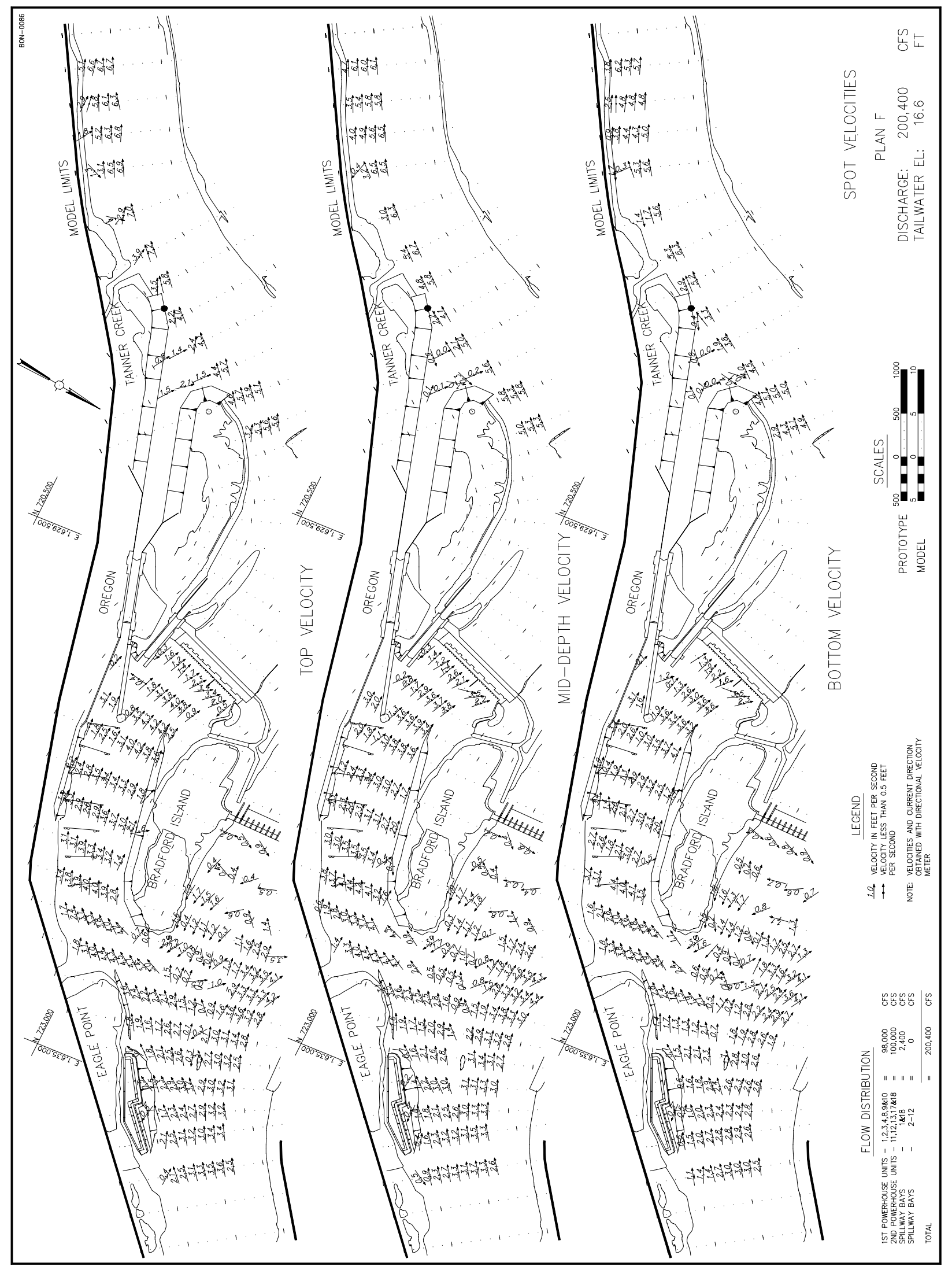

Plate 98 


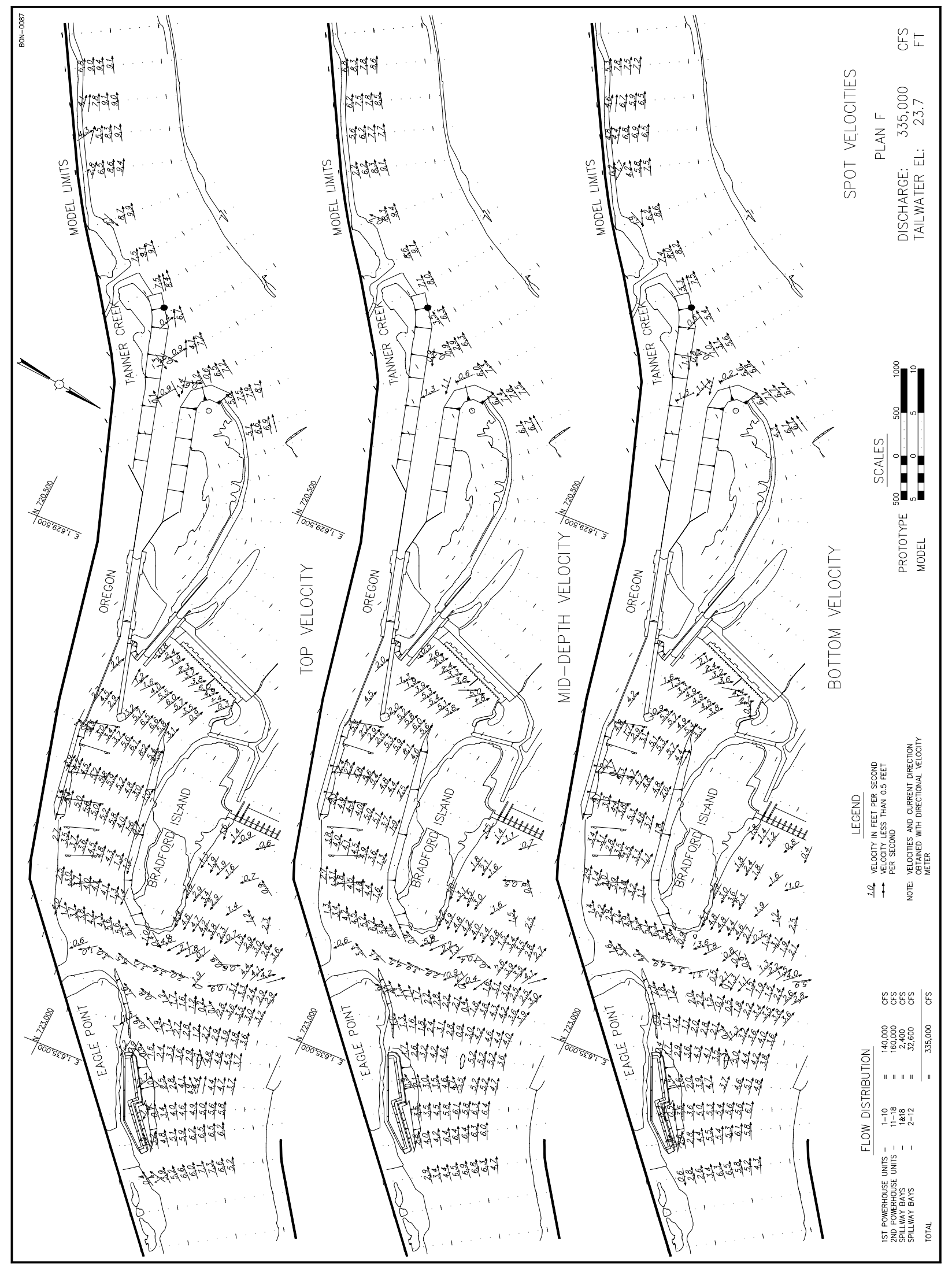

Plate 99 


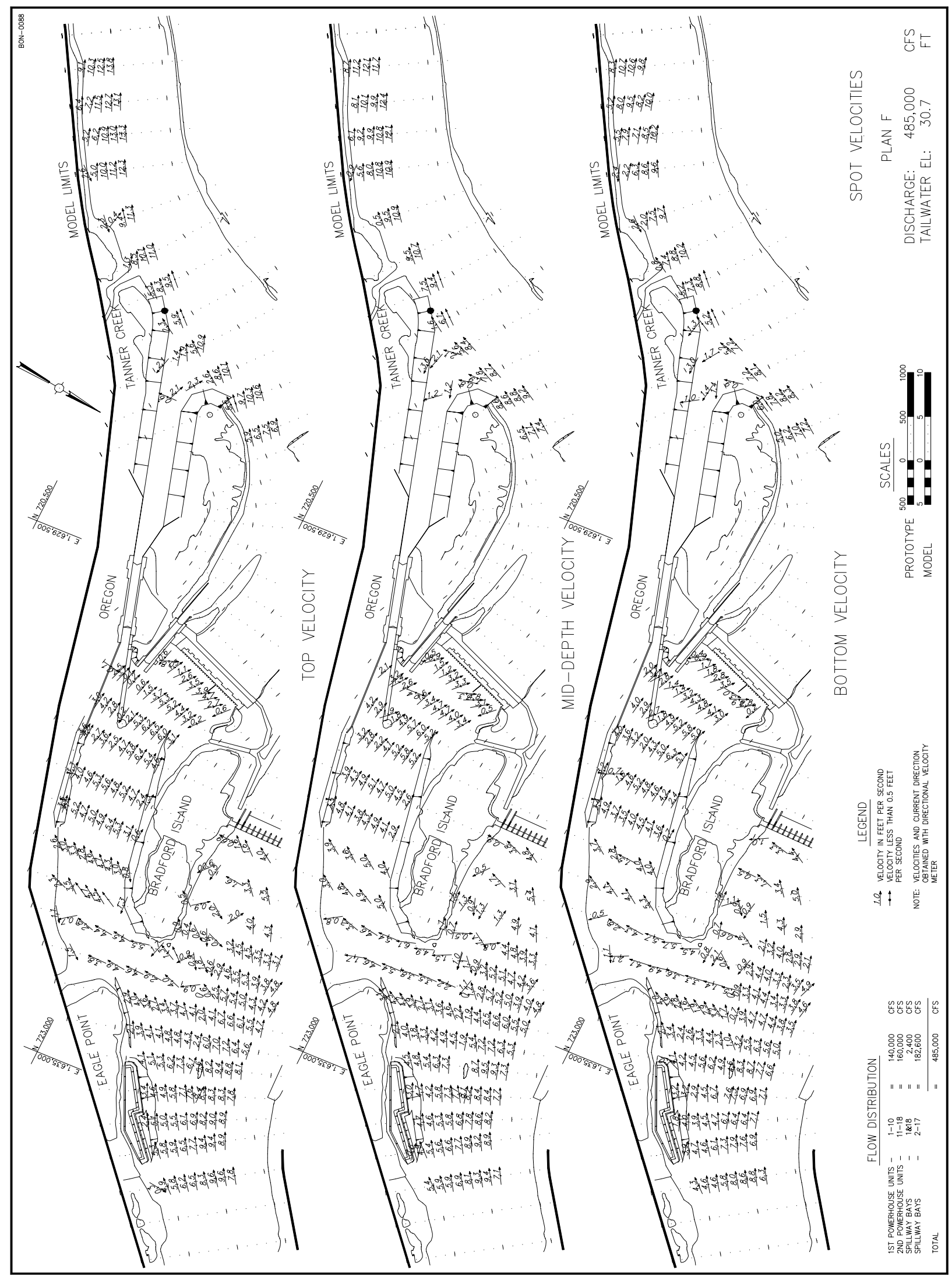

Plate 100 


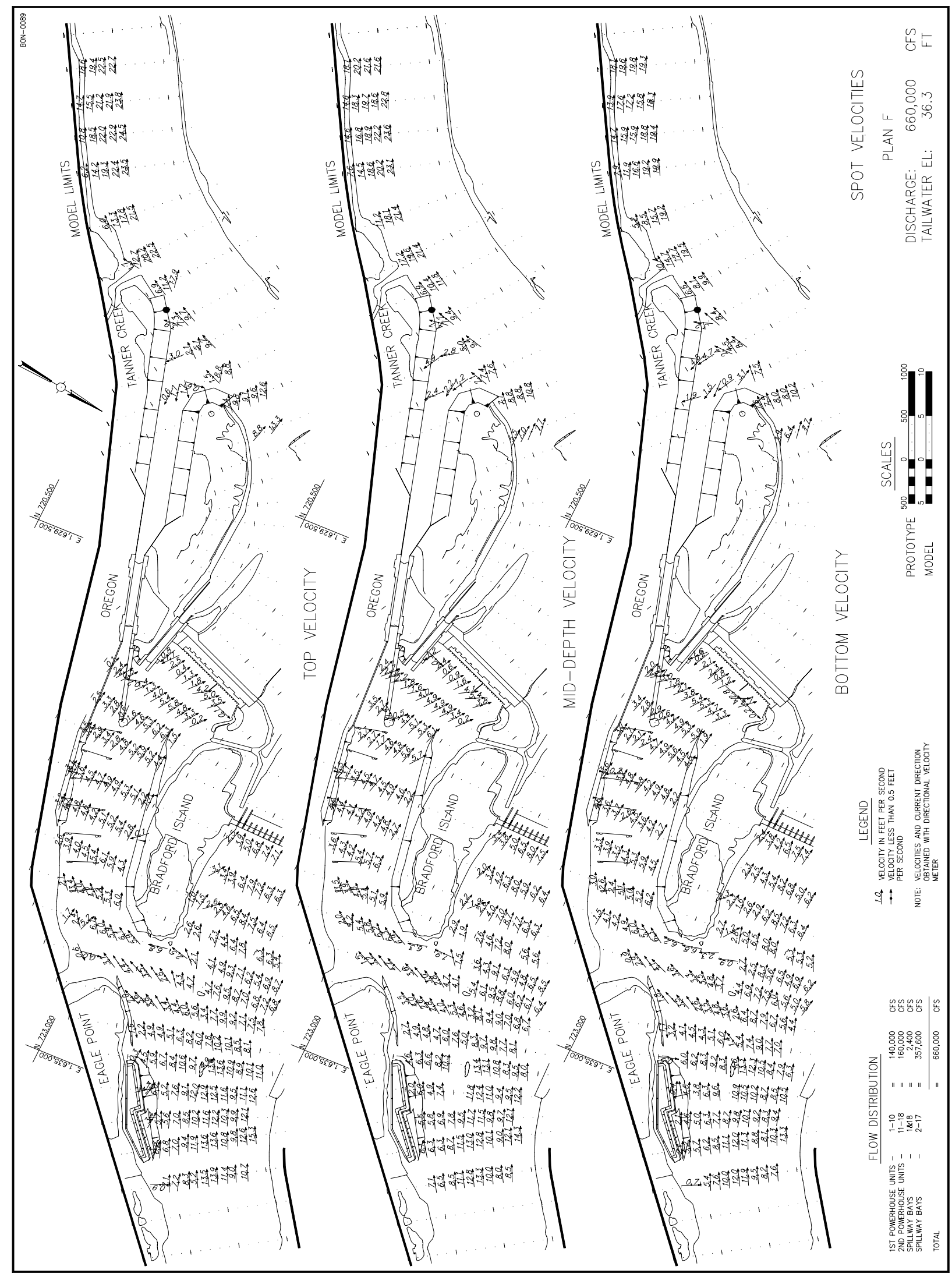

Plate 101 


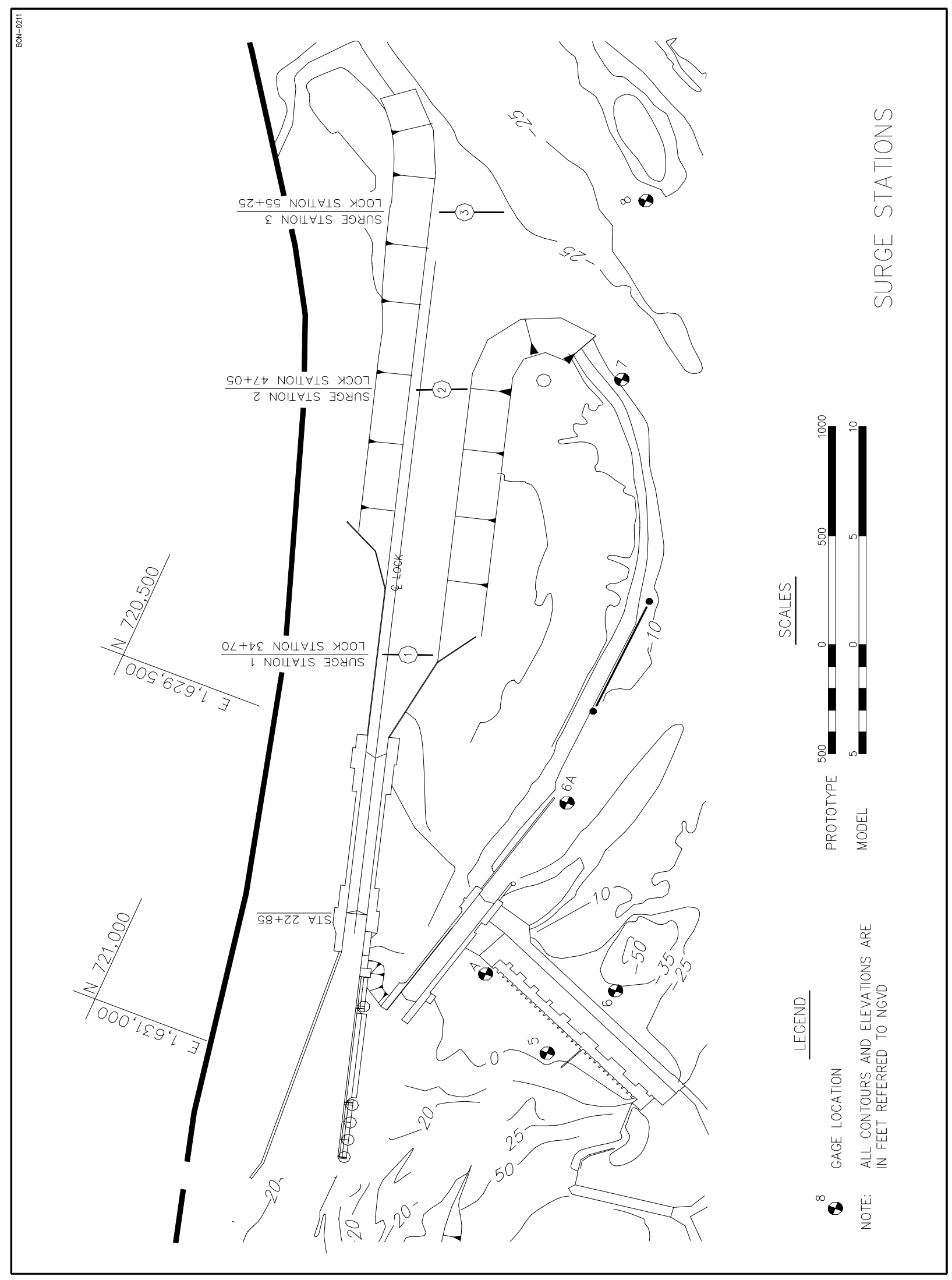

Plate 102 


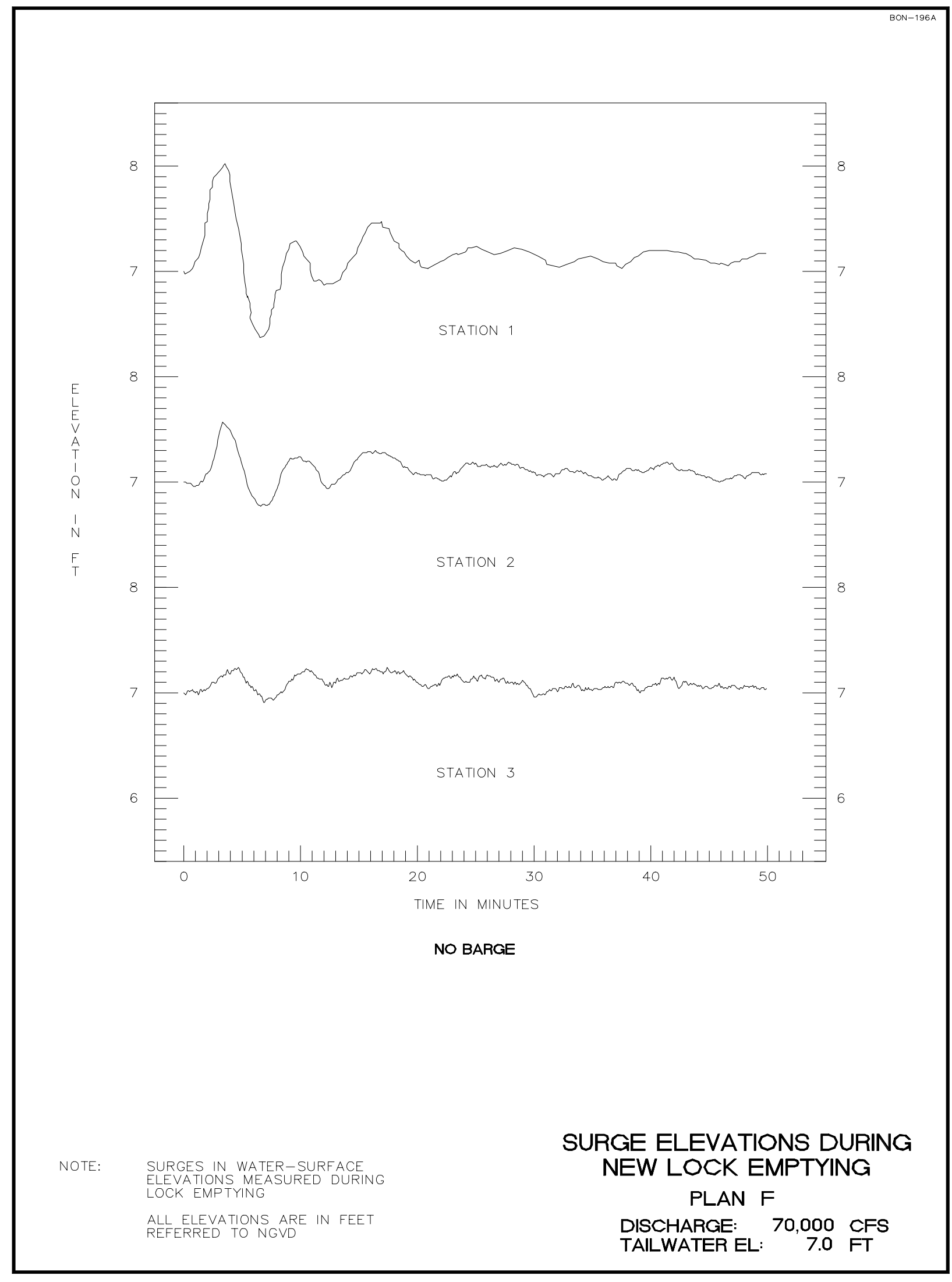

Plate 103 


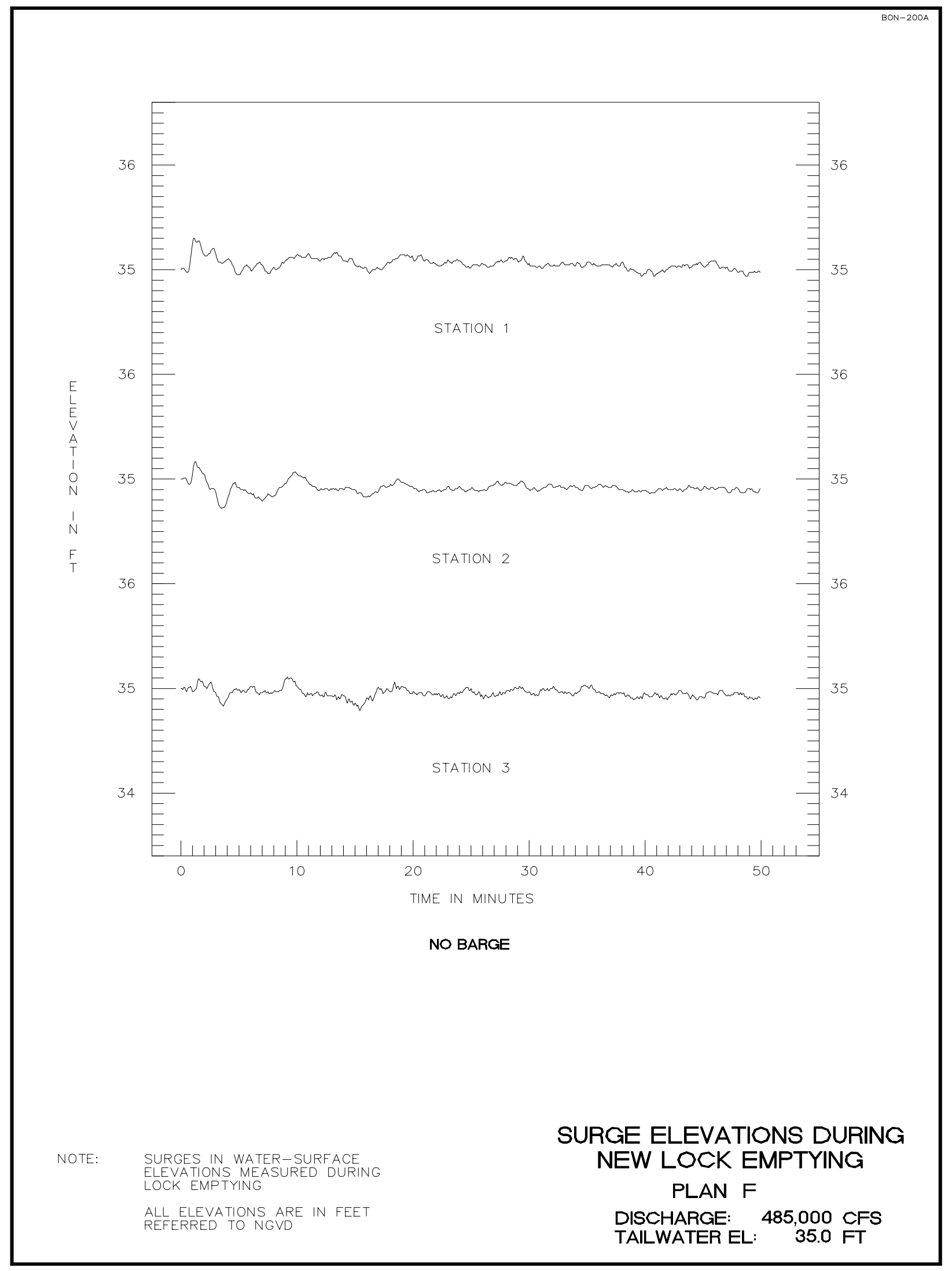

Plate 104 


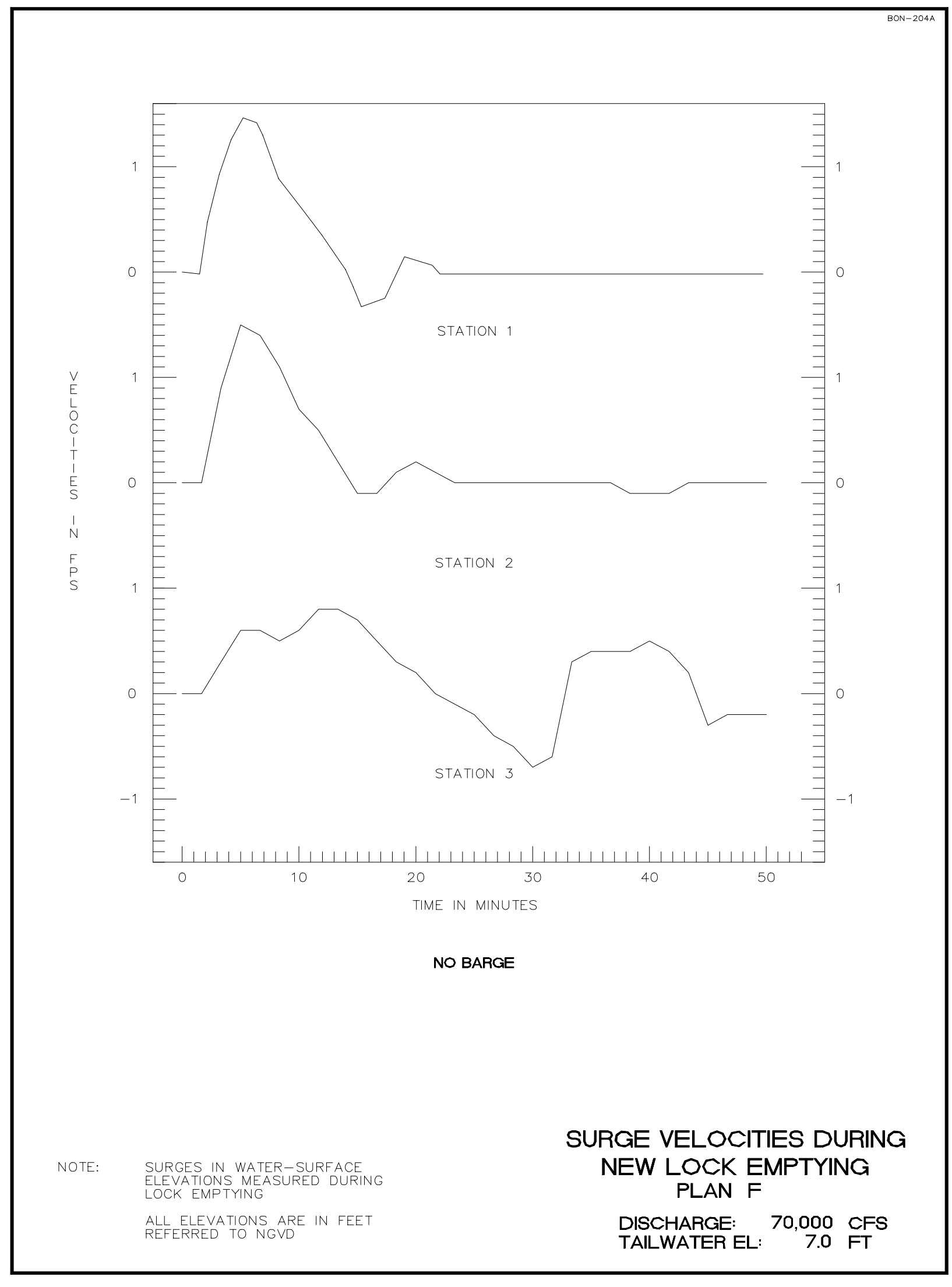

Plate 105 


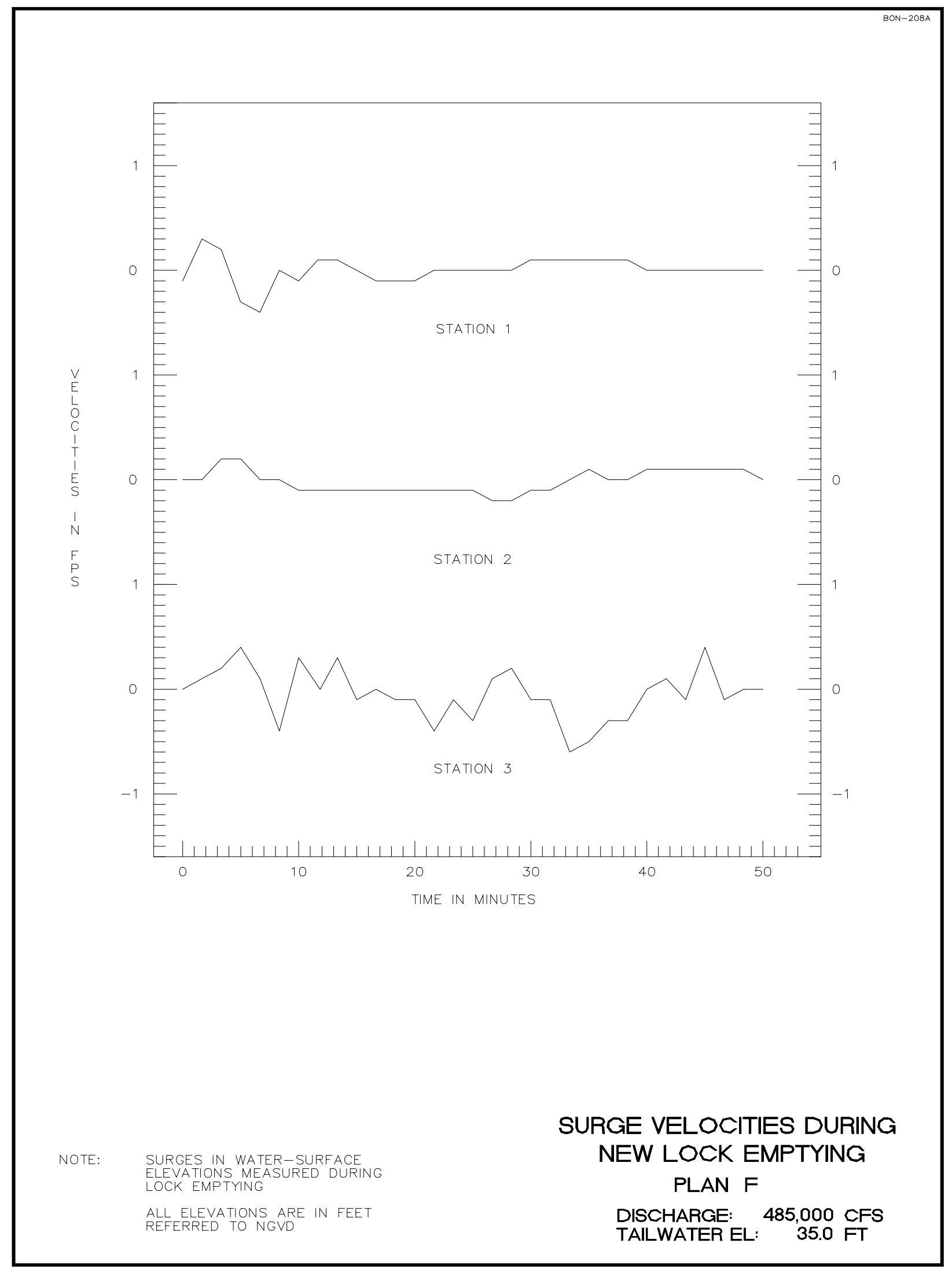

Plate 106 


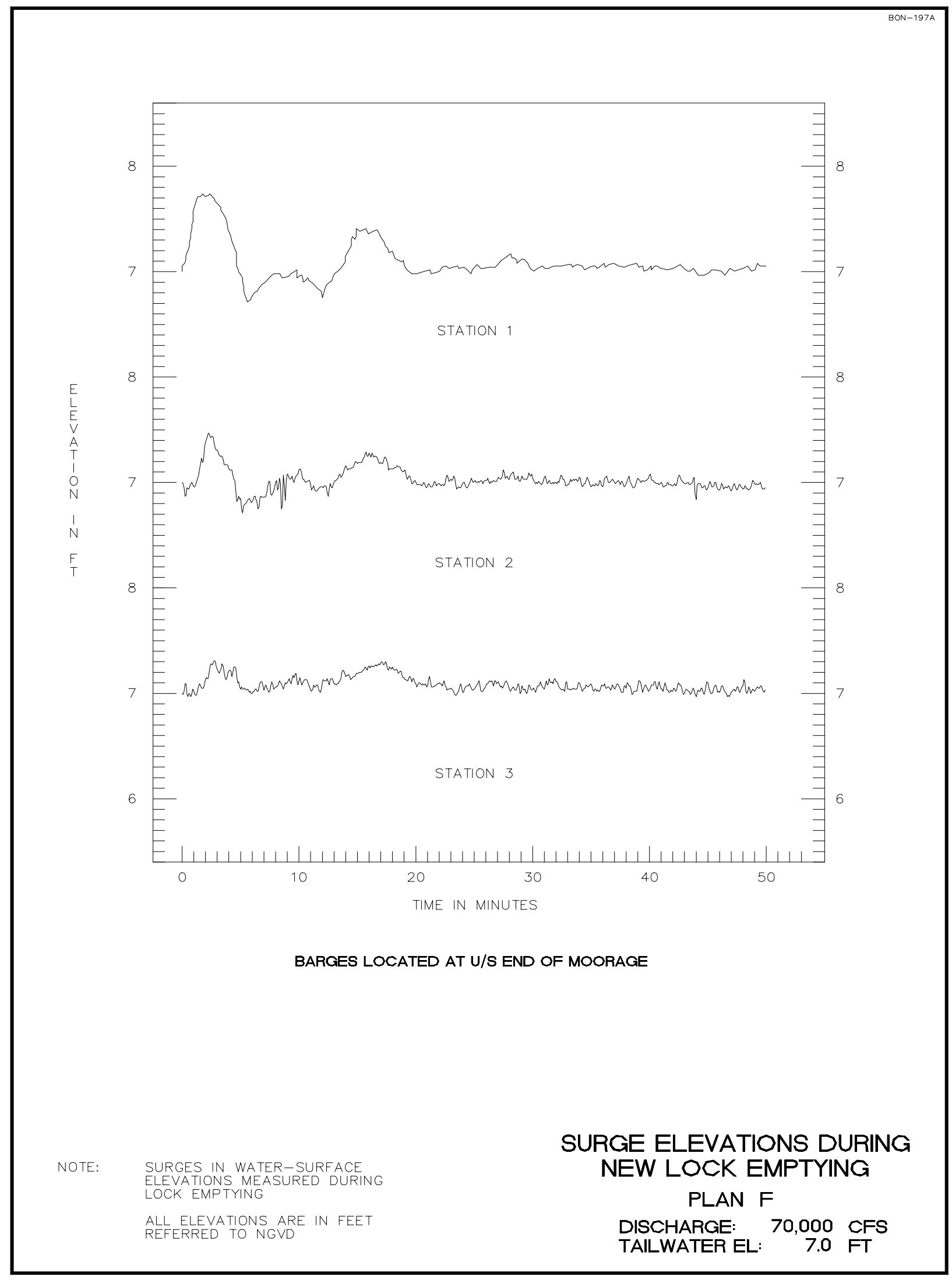

Plate 107 


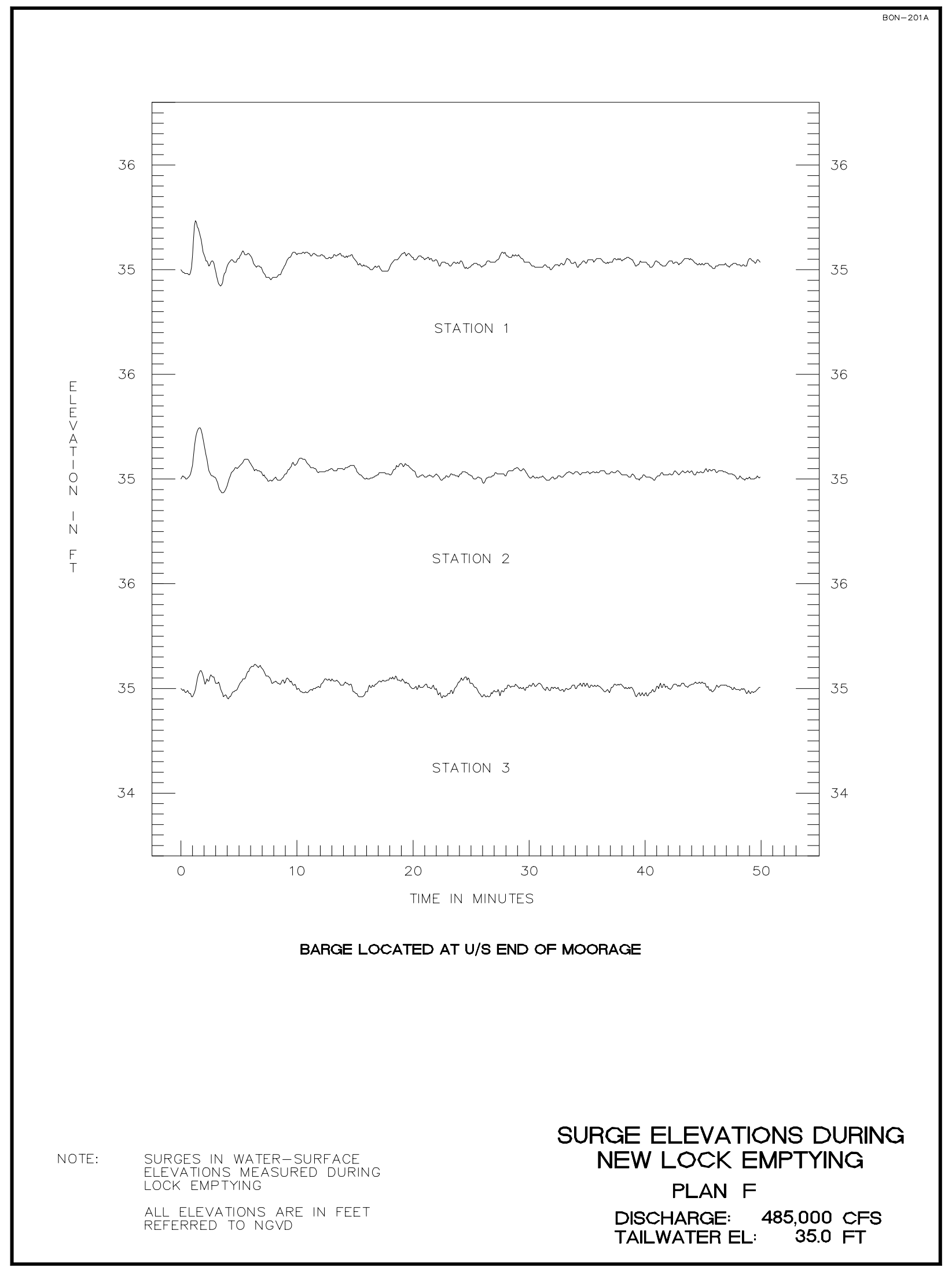

Plate 108 


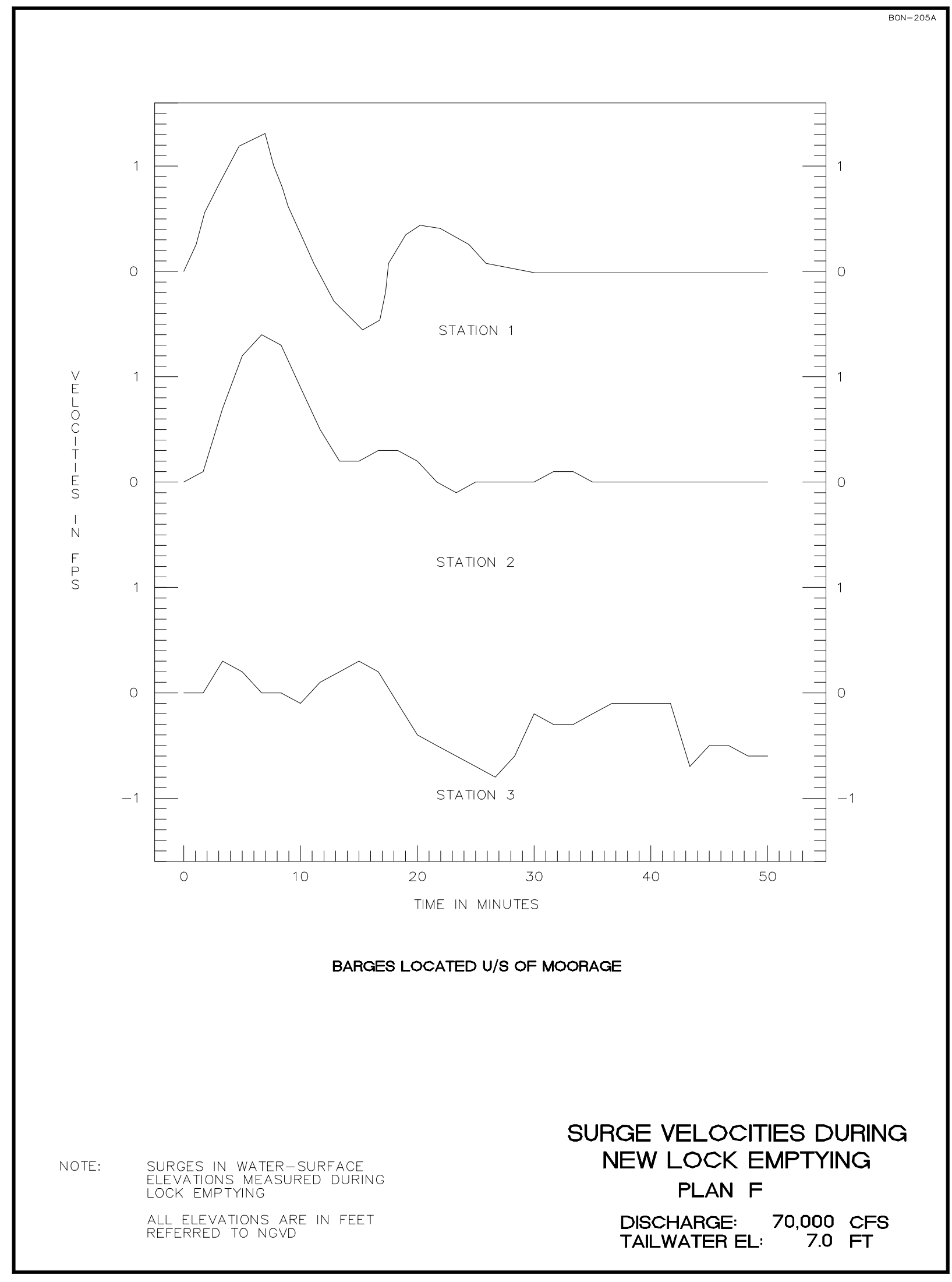

Plate 109 


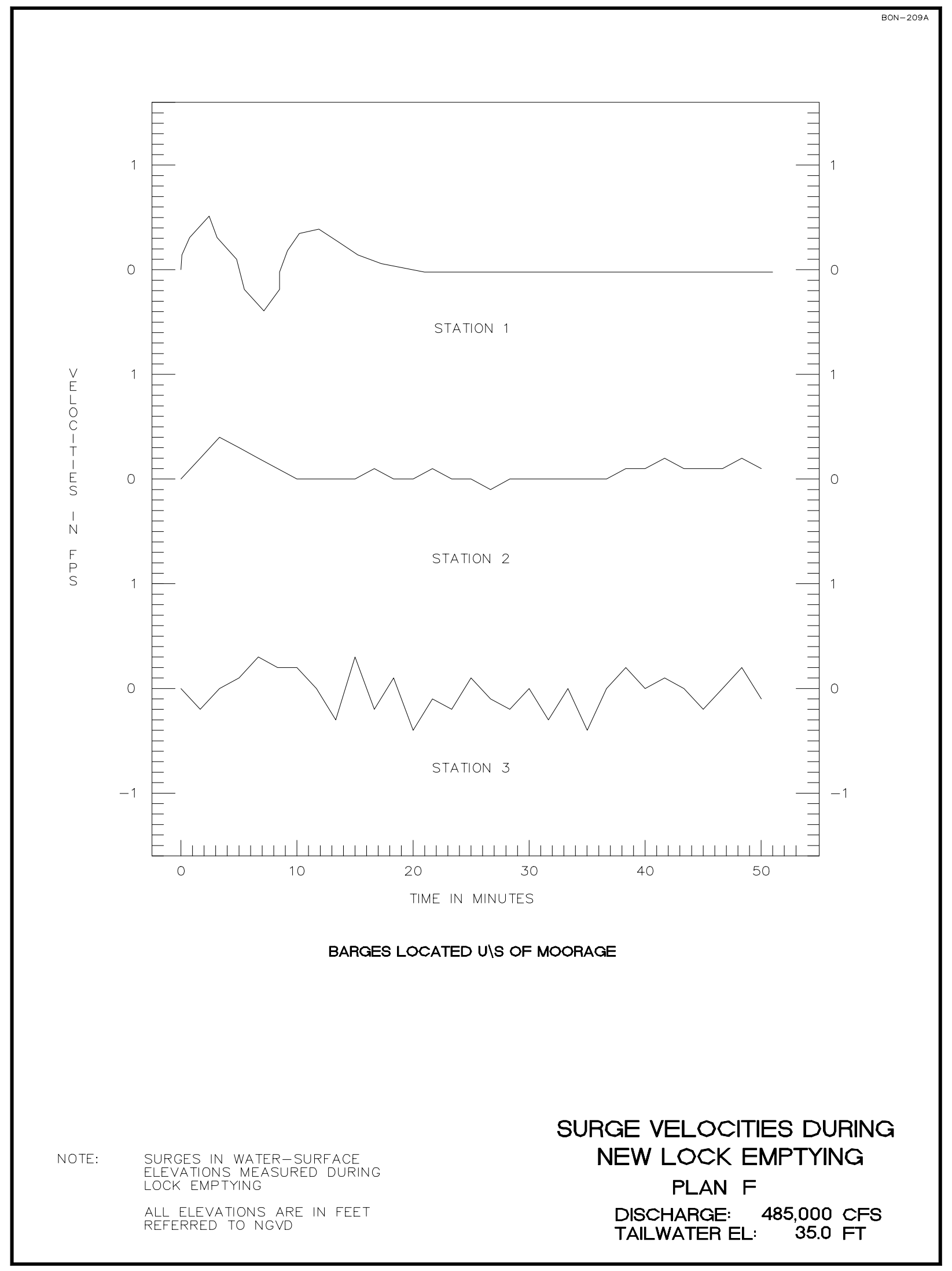

Plate 110 


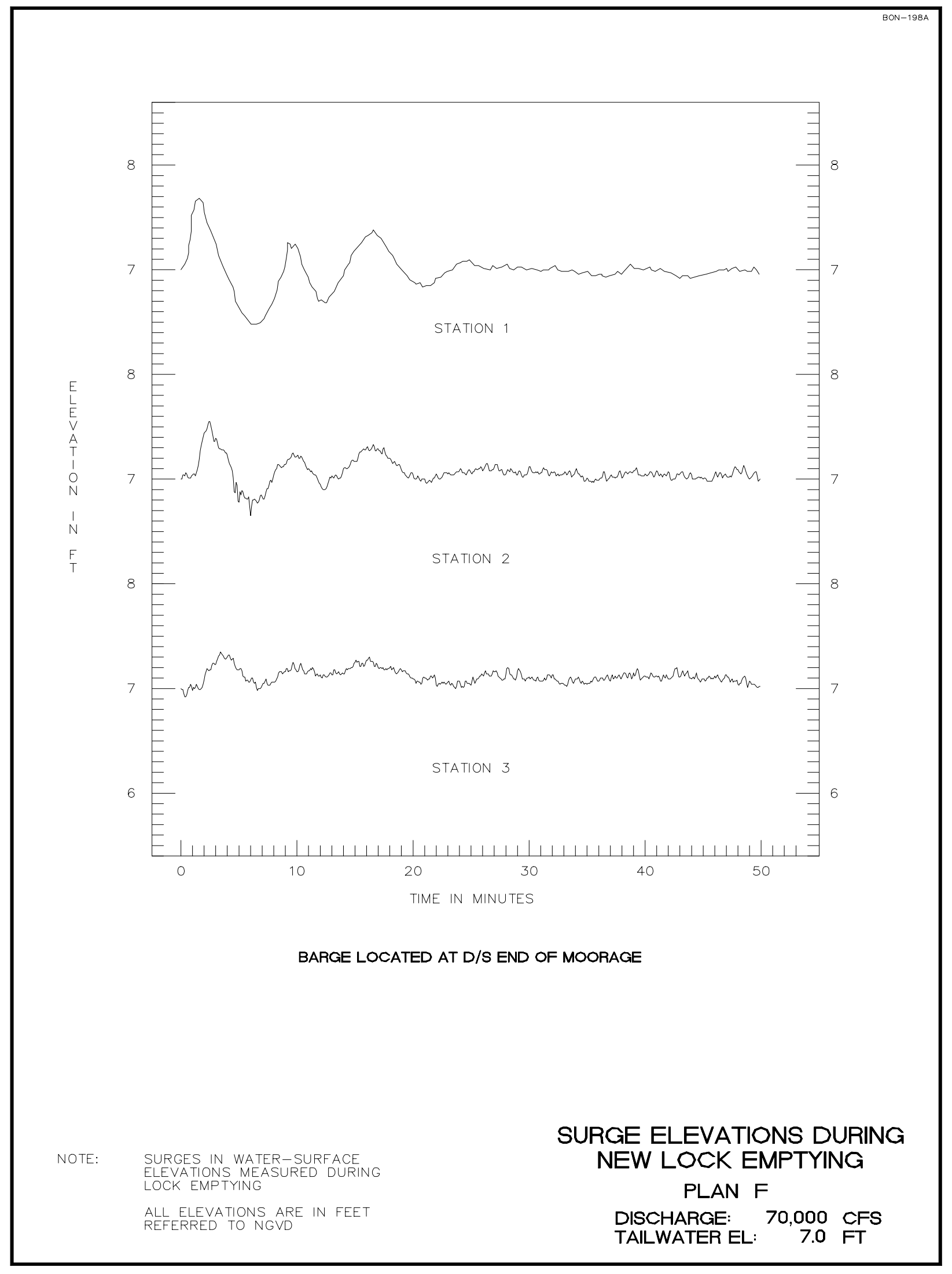

Plate 111 


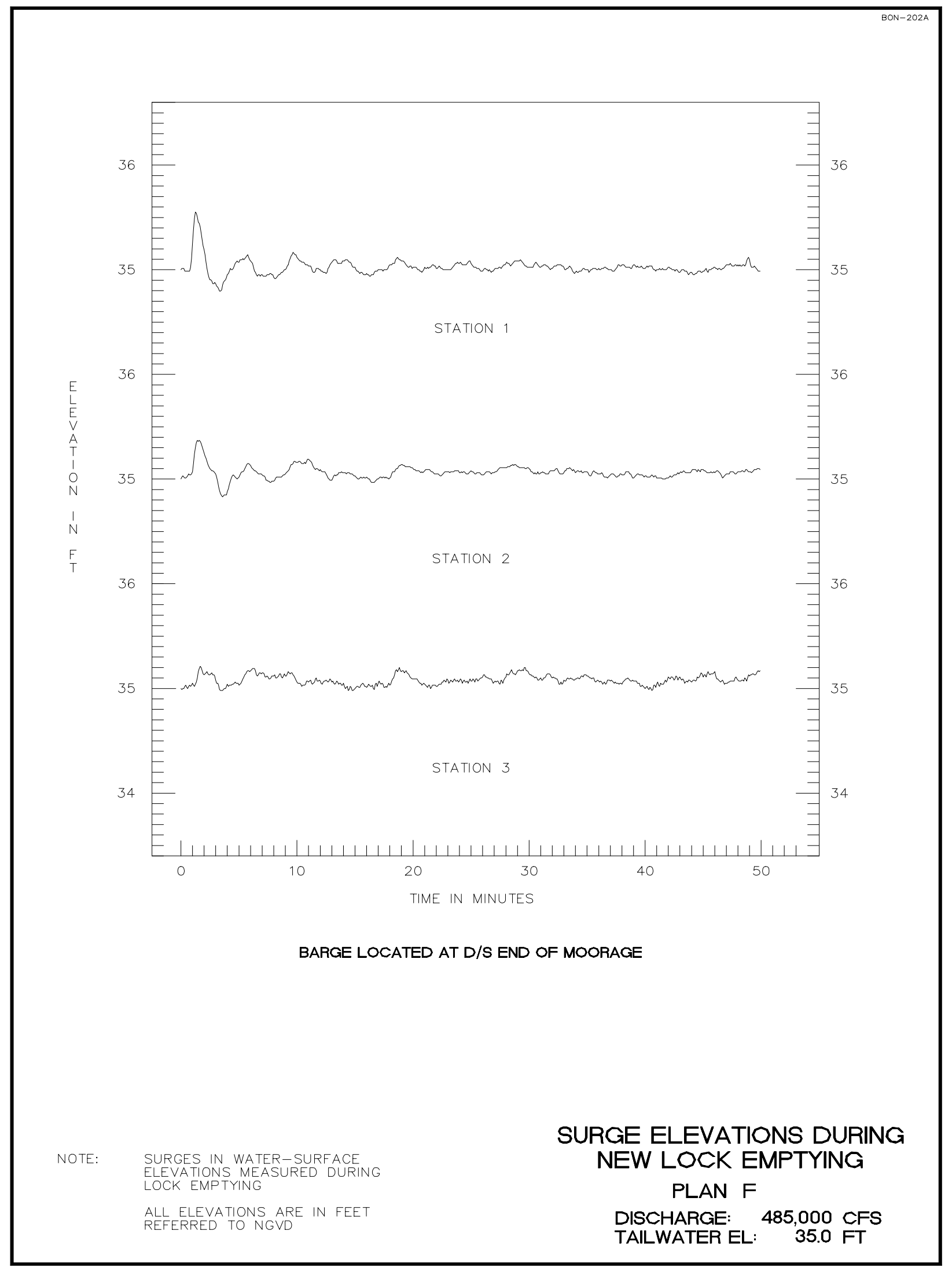

Plate 112 


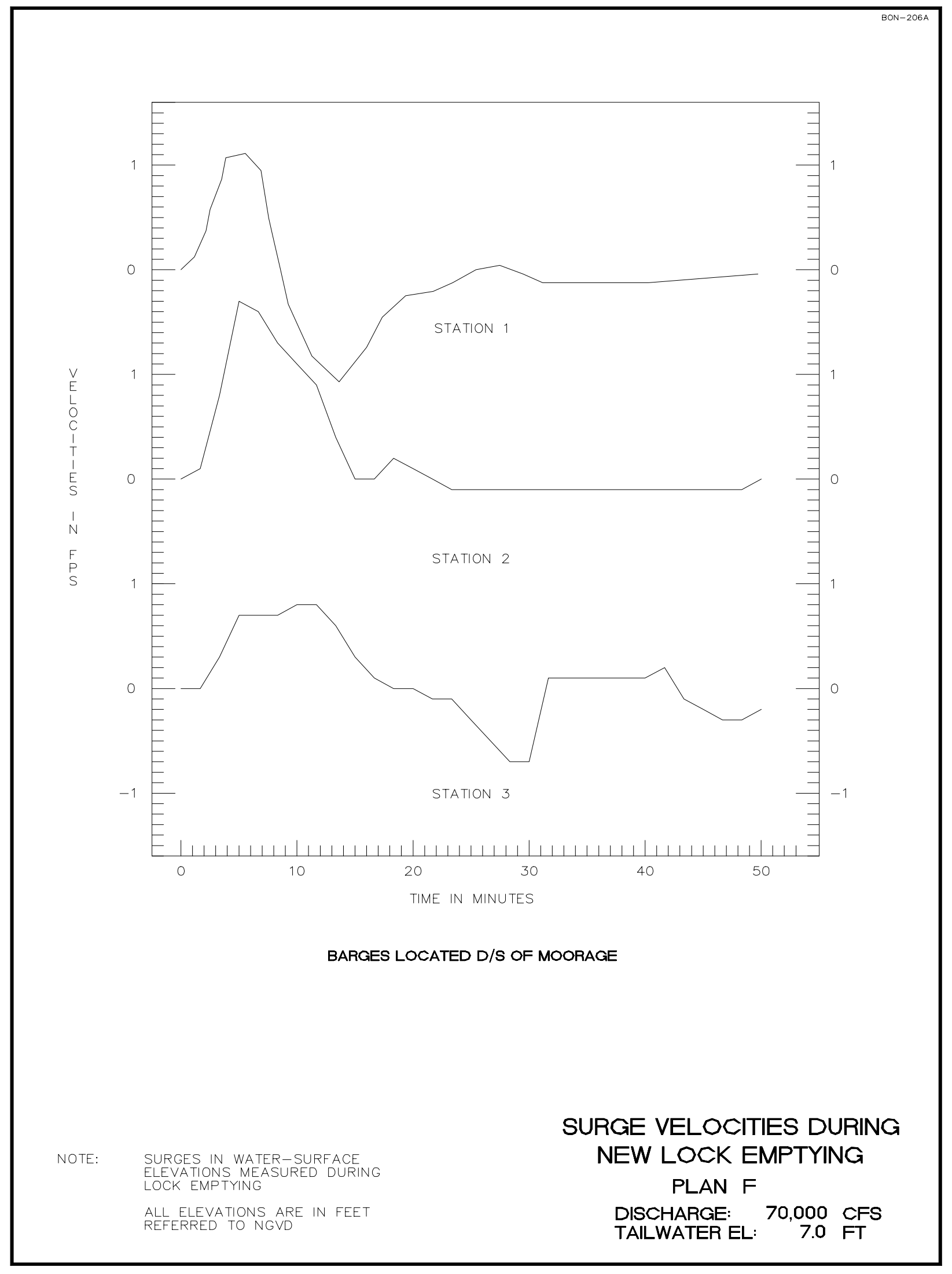

Plate 113 


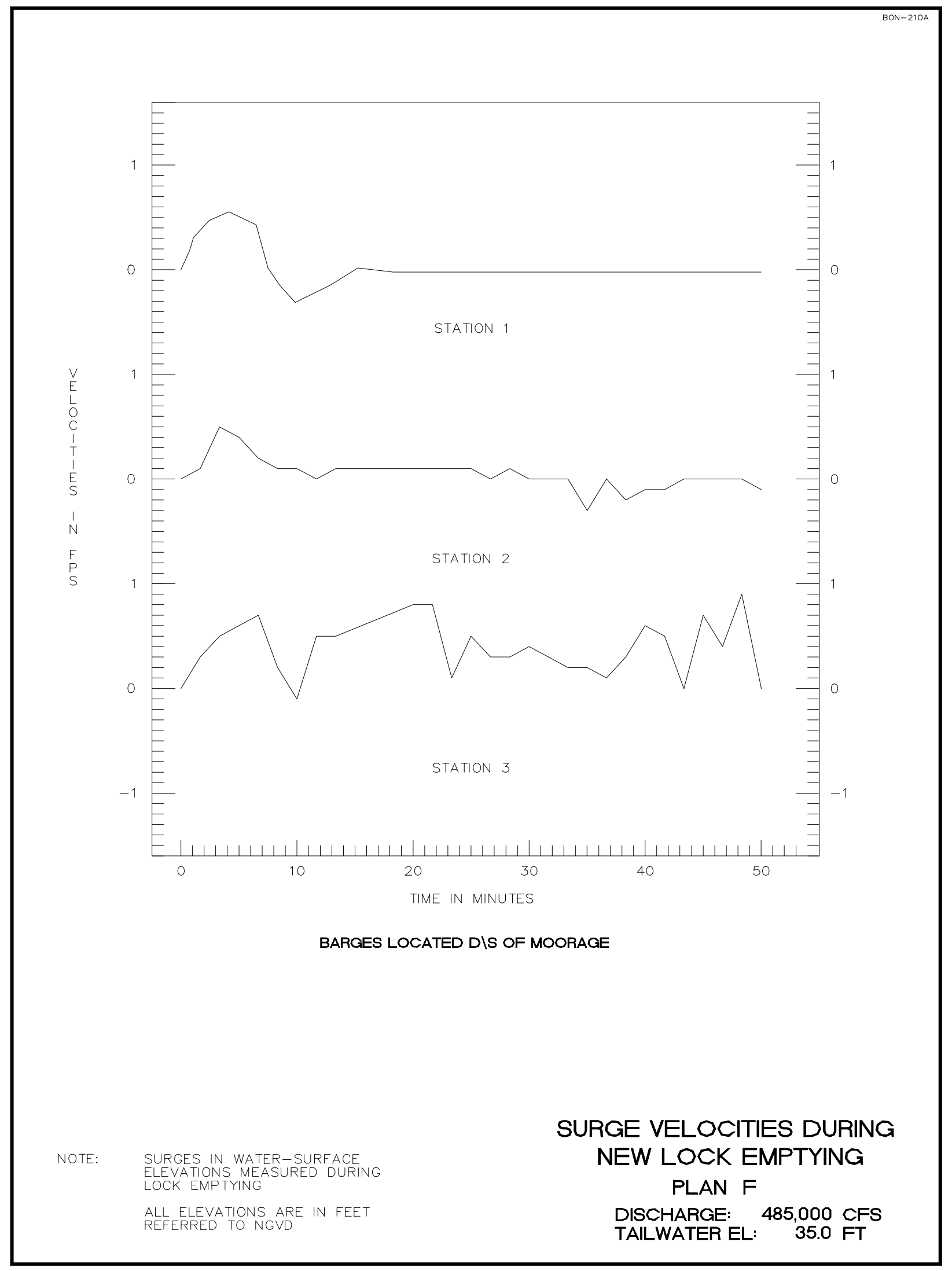

Plate 114 


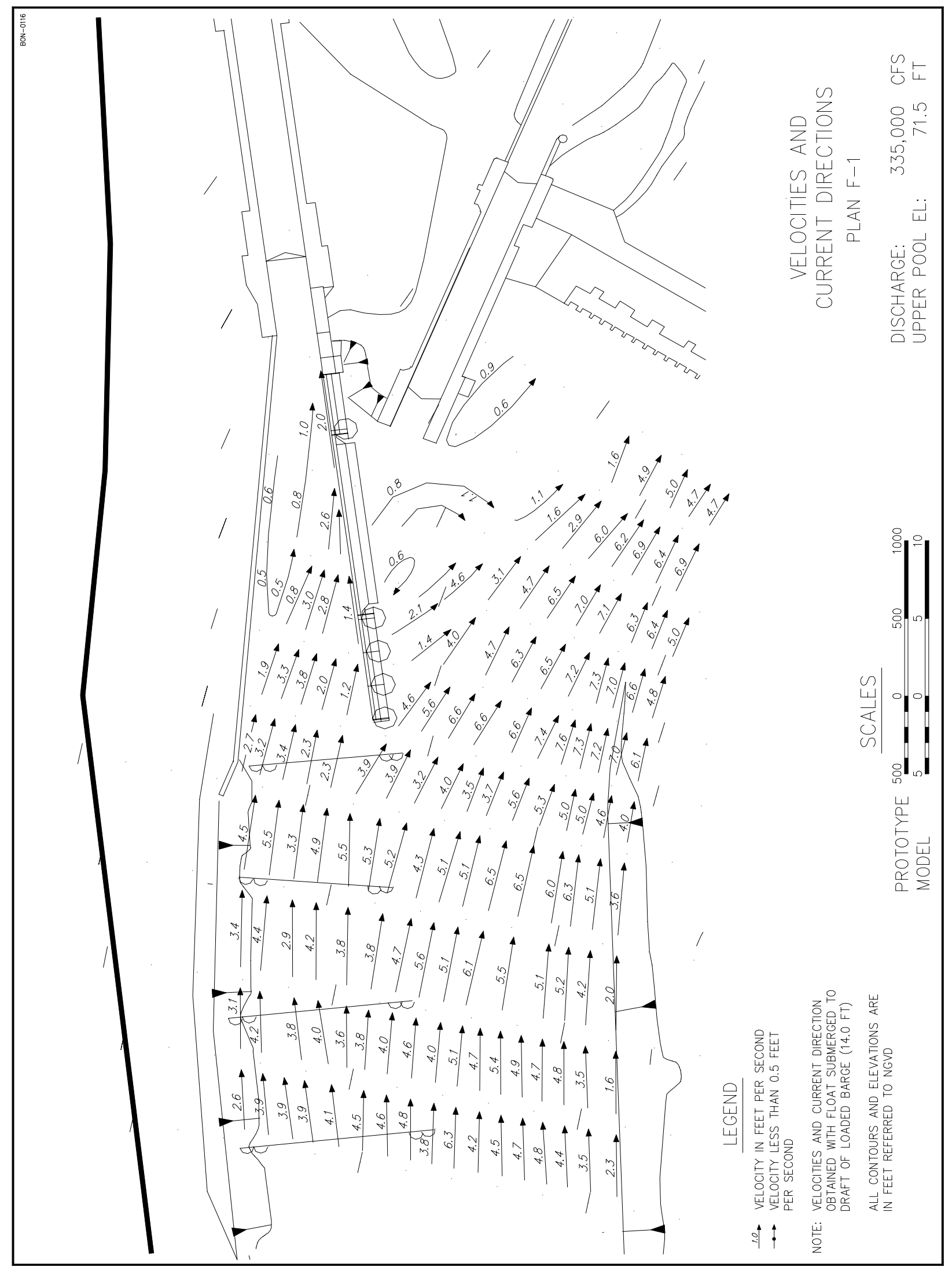

Plate 115 


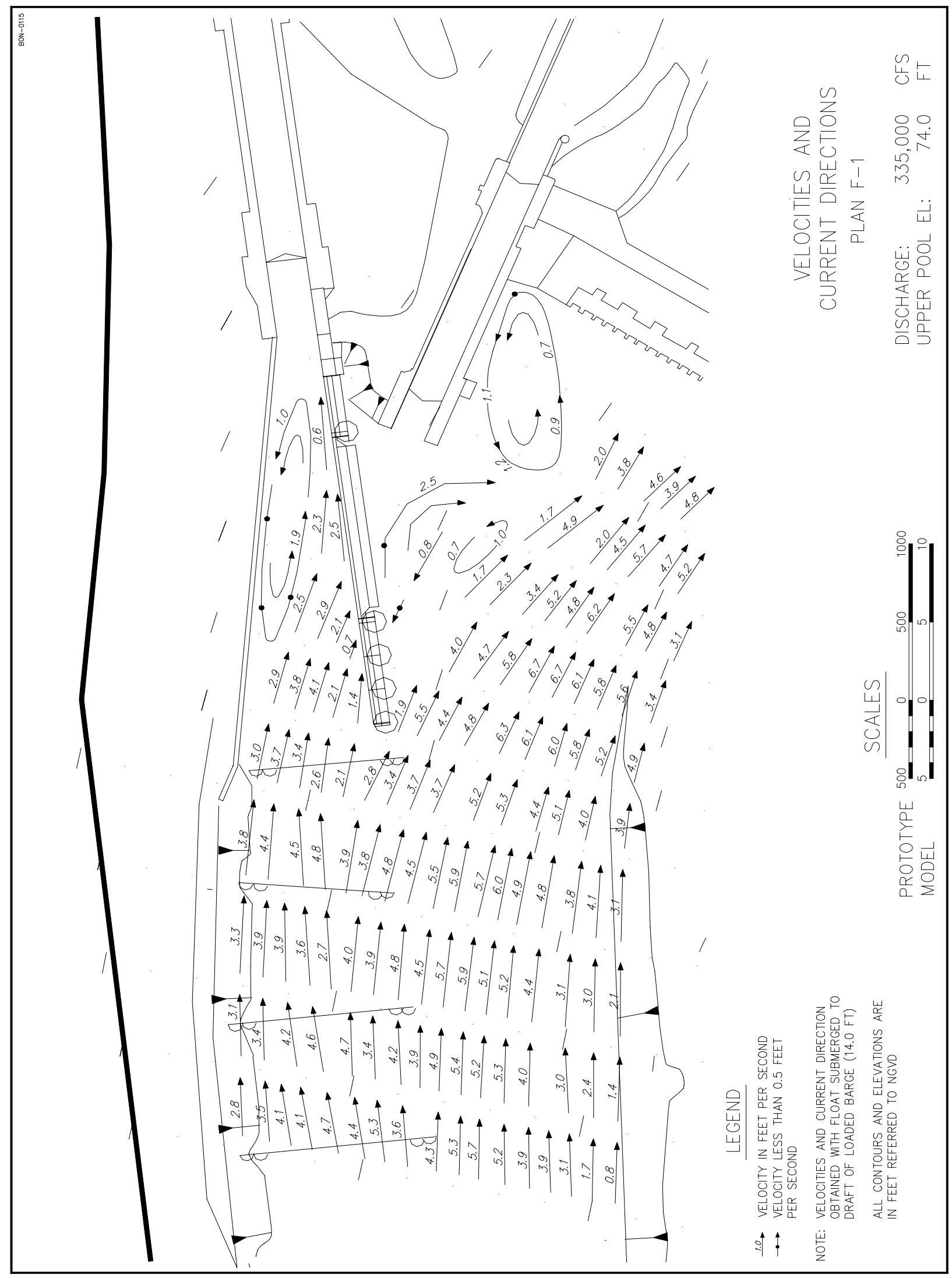

Plate 116 


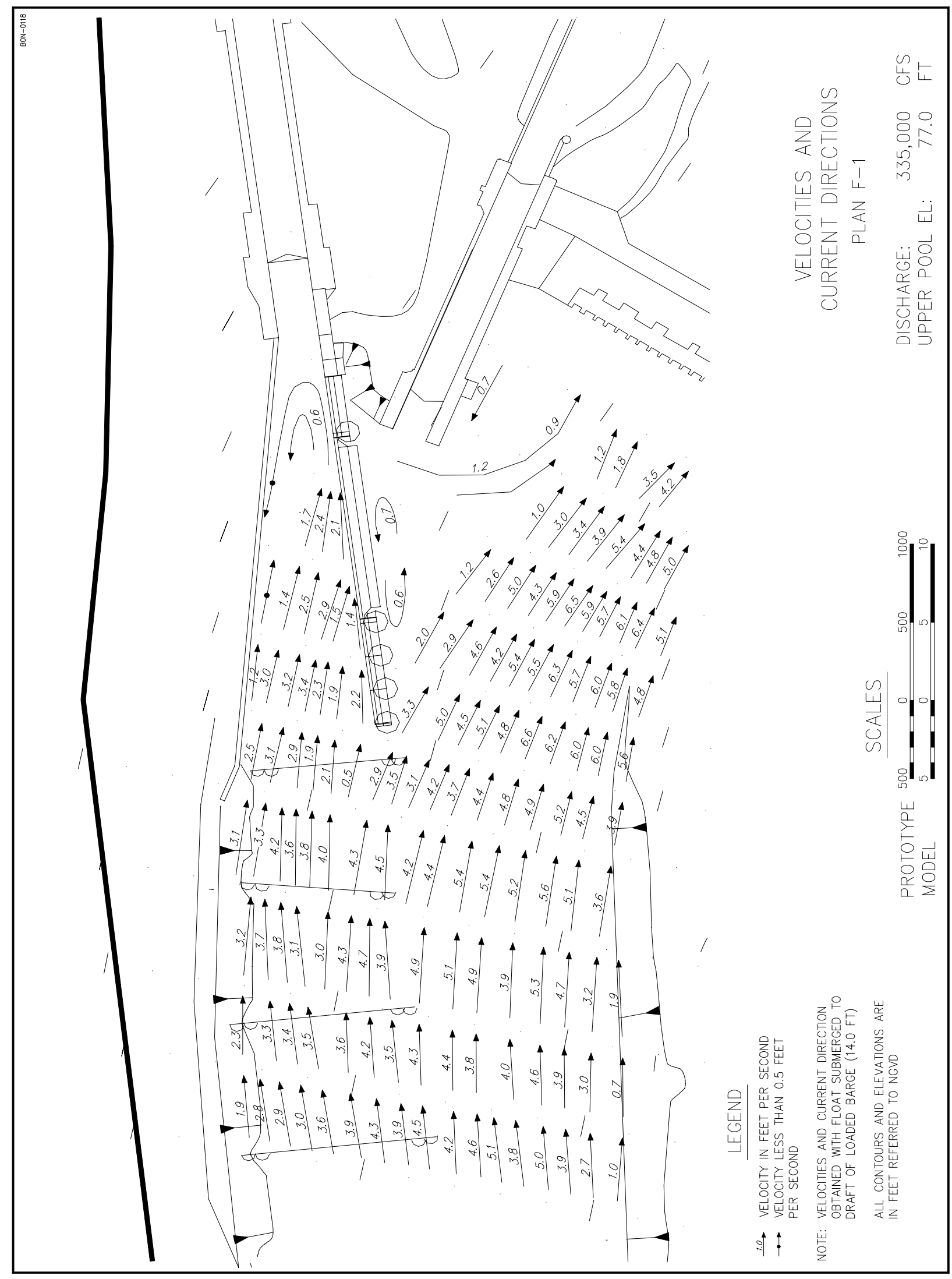

Plate 117 


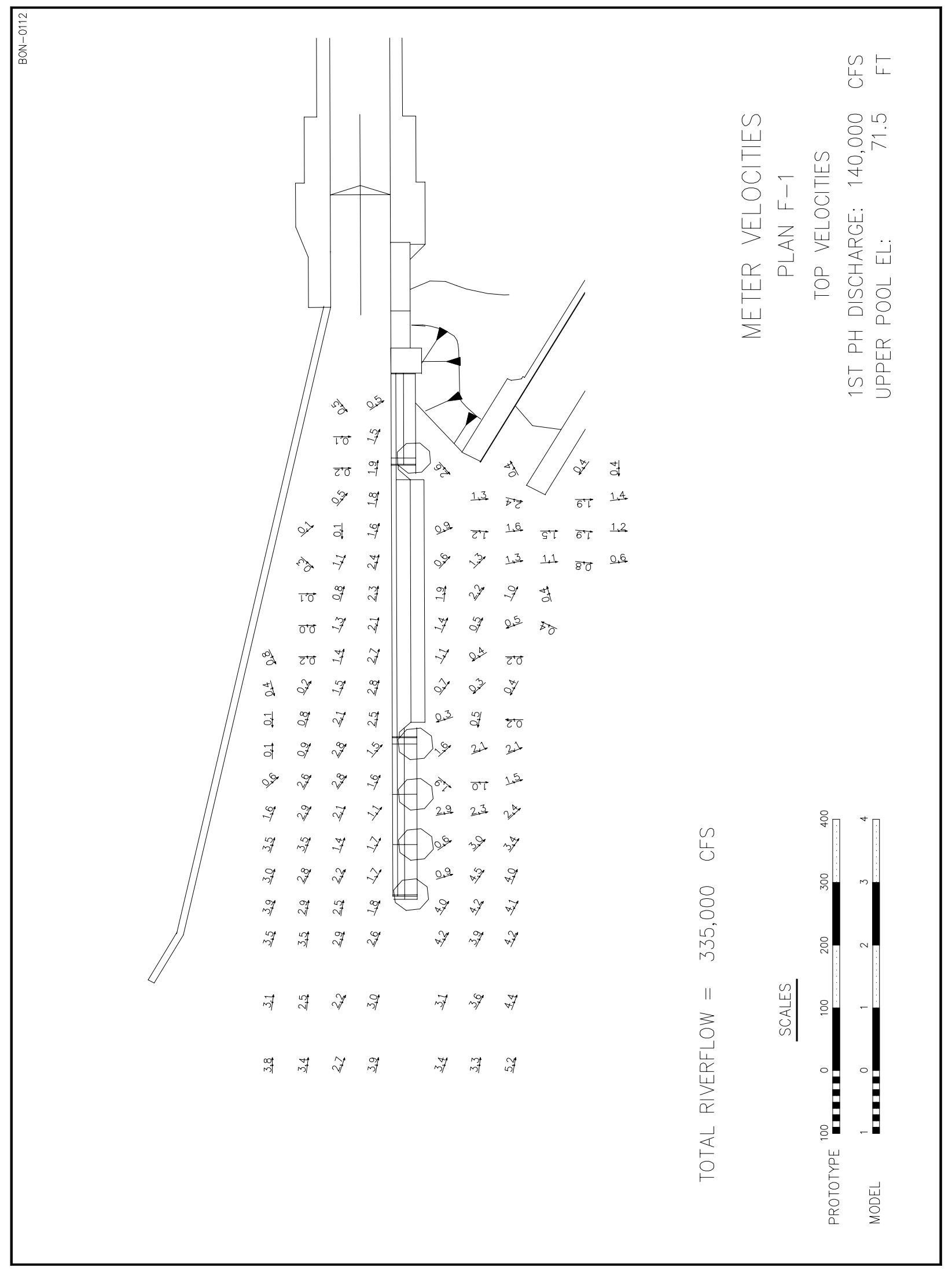

Plate 118 


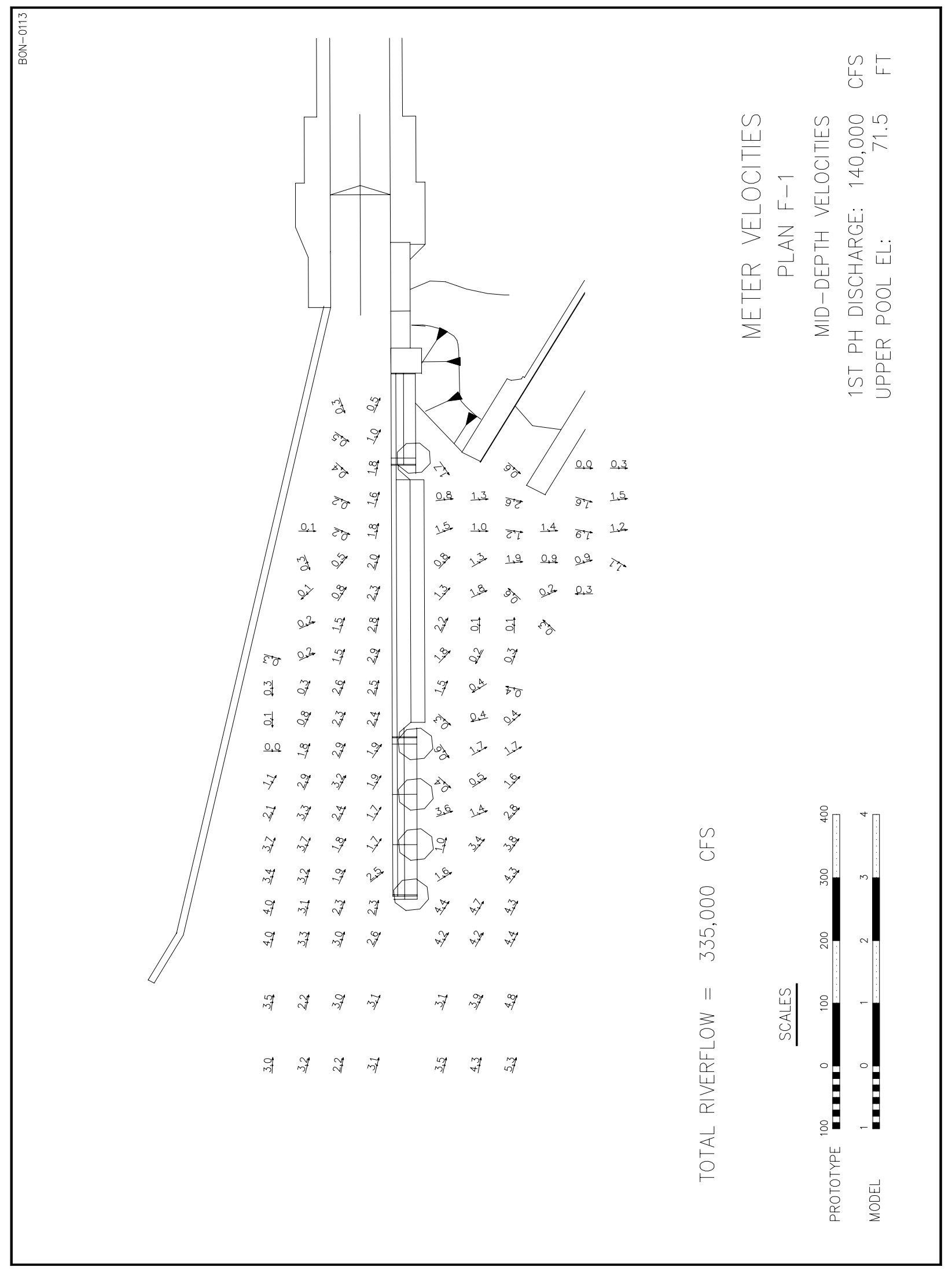

Plate 119 


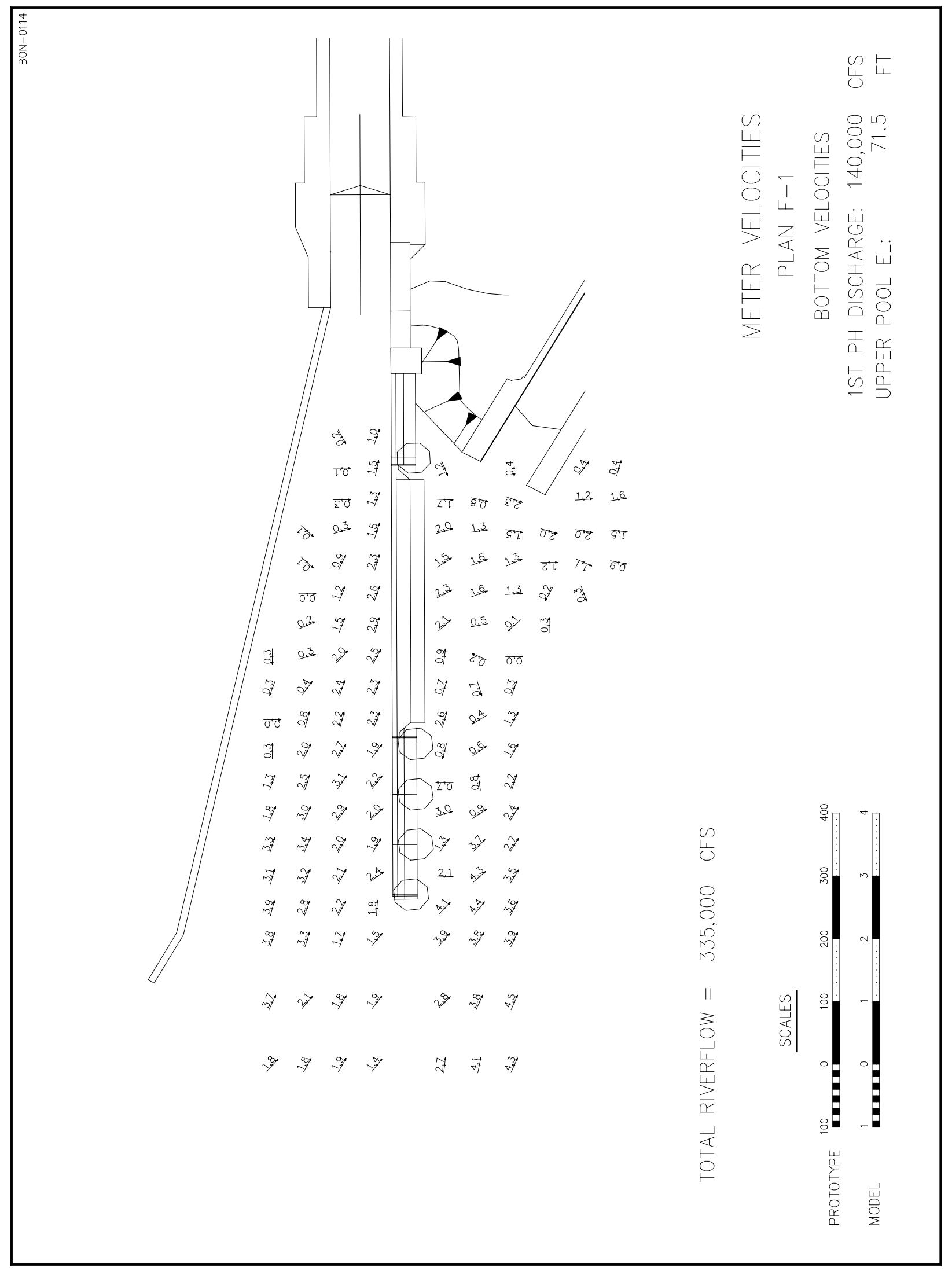

Plate 120 


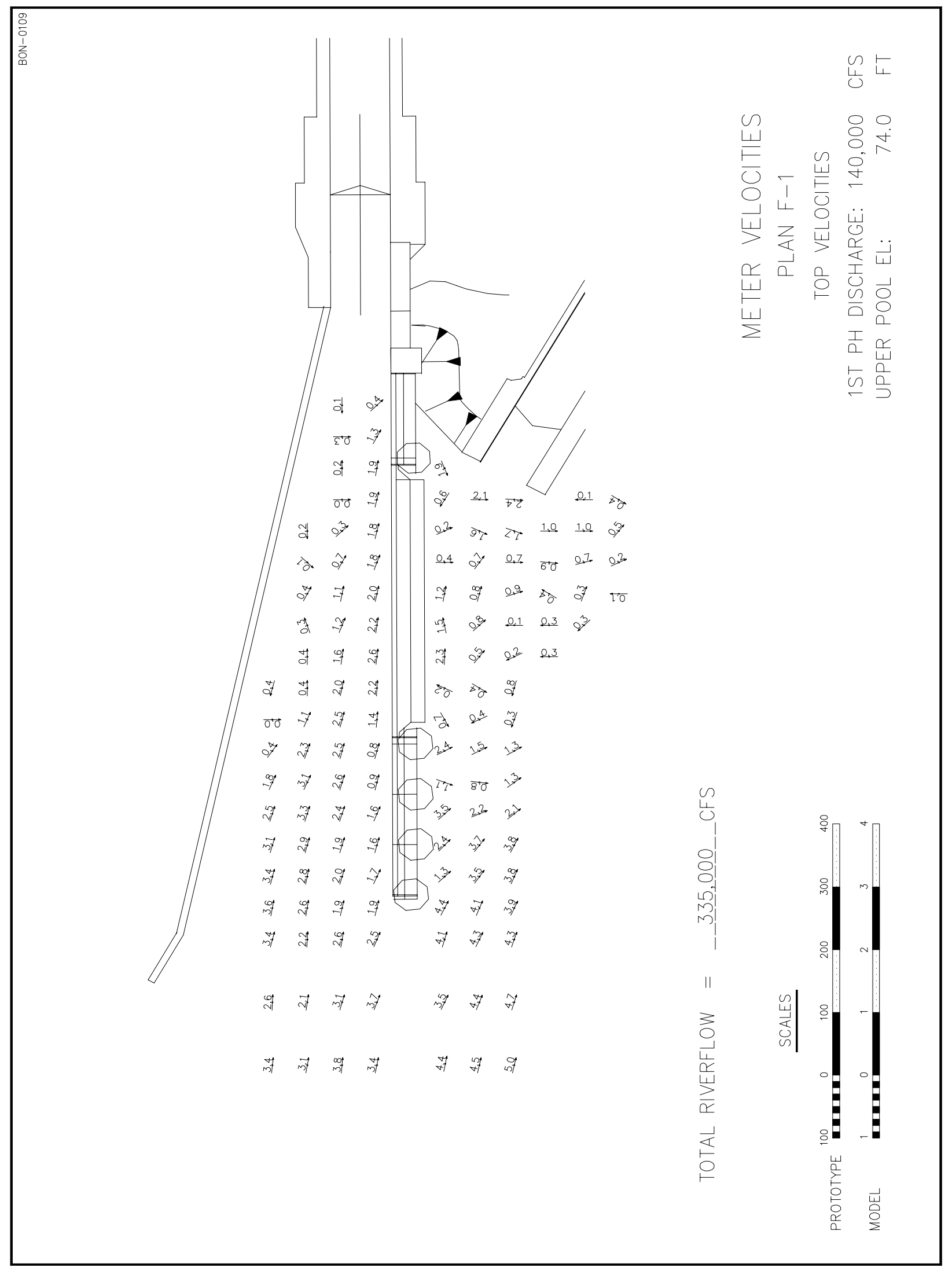

Plate 121 


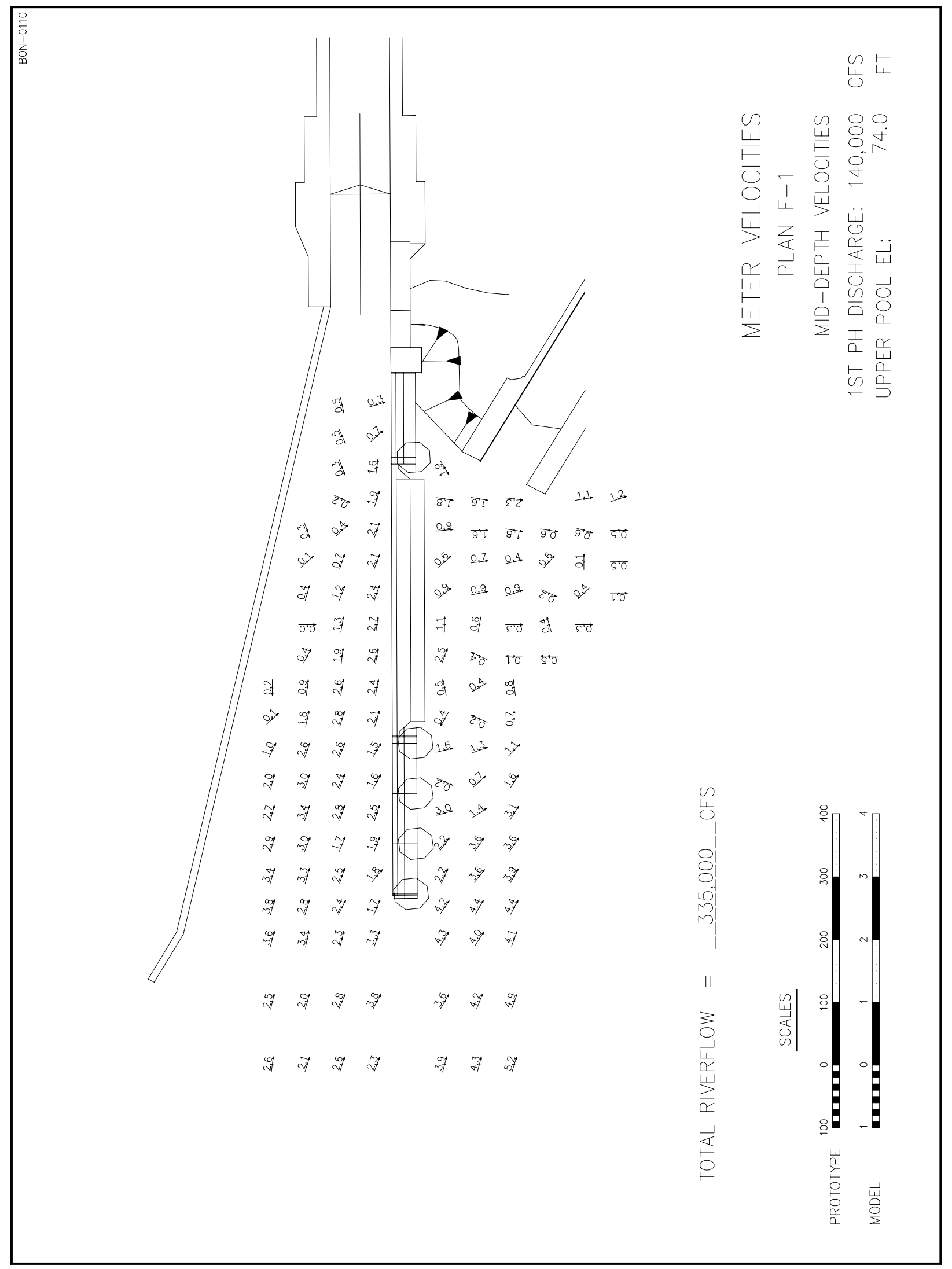

Plate 122 


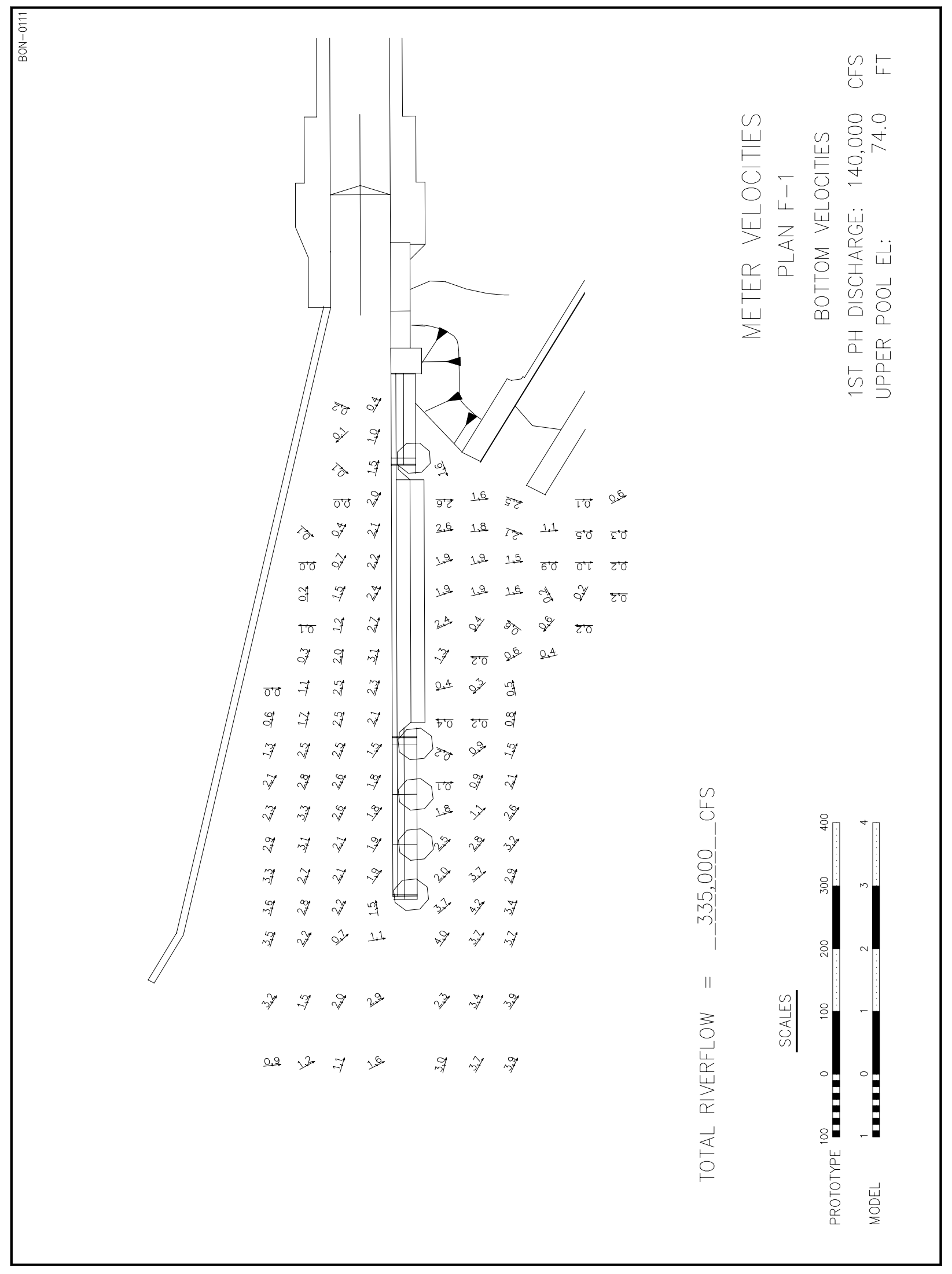

Plate 123 


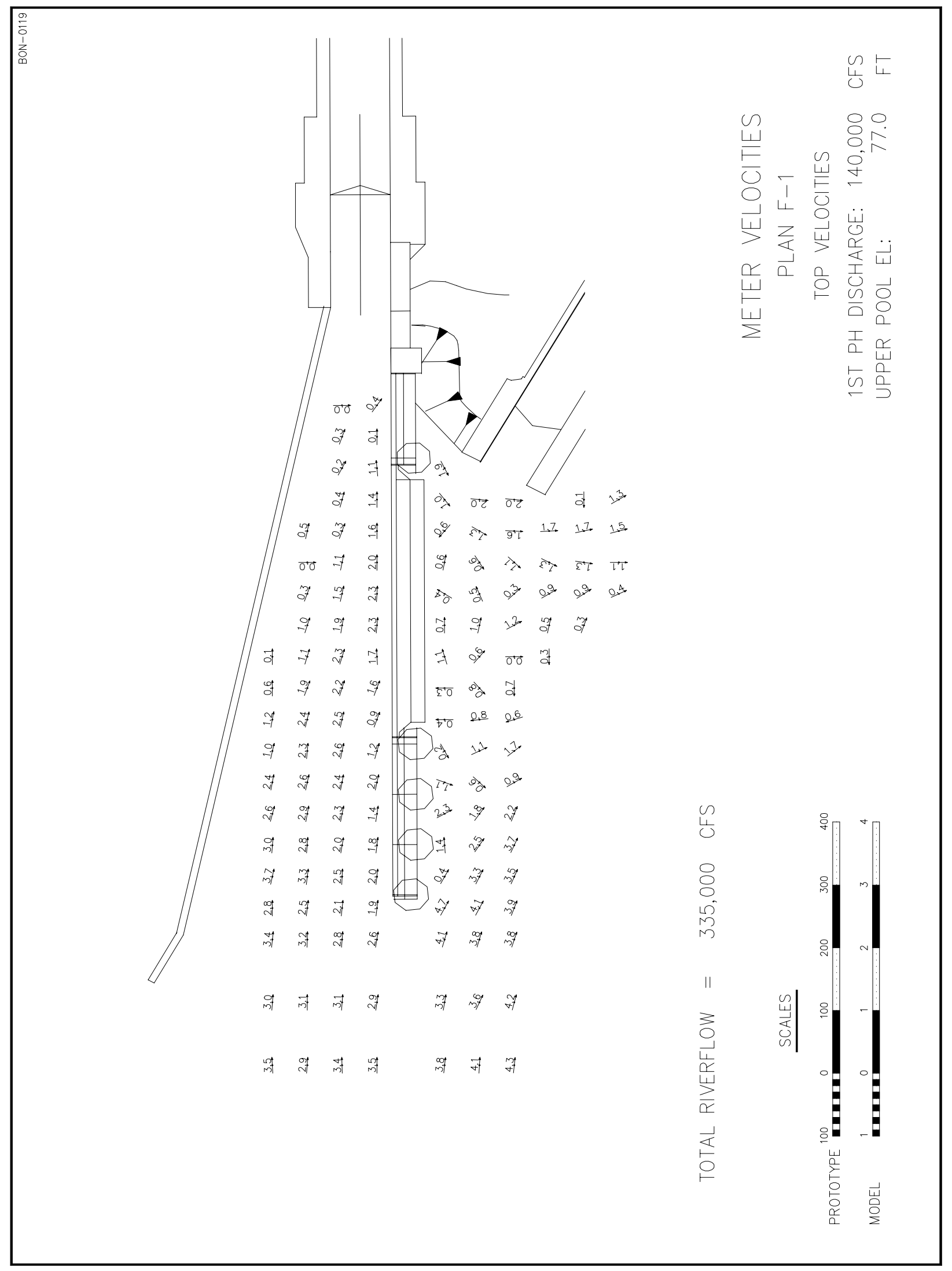

Plate 124 


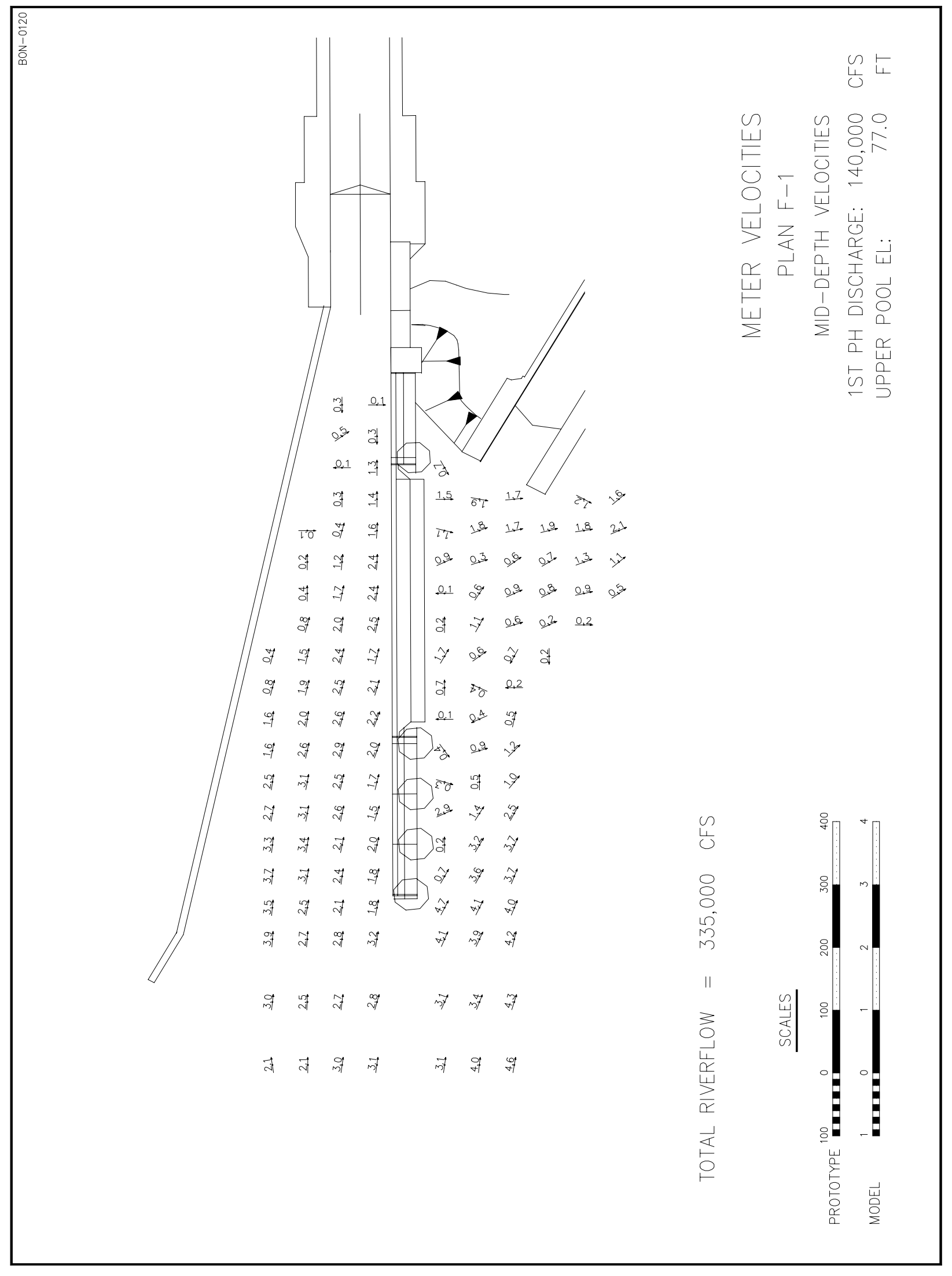

Plate 125 


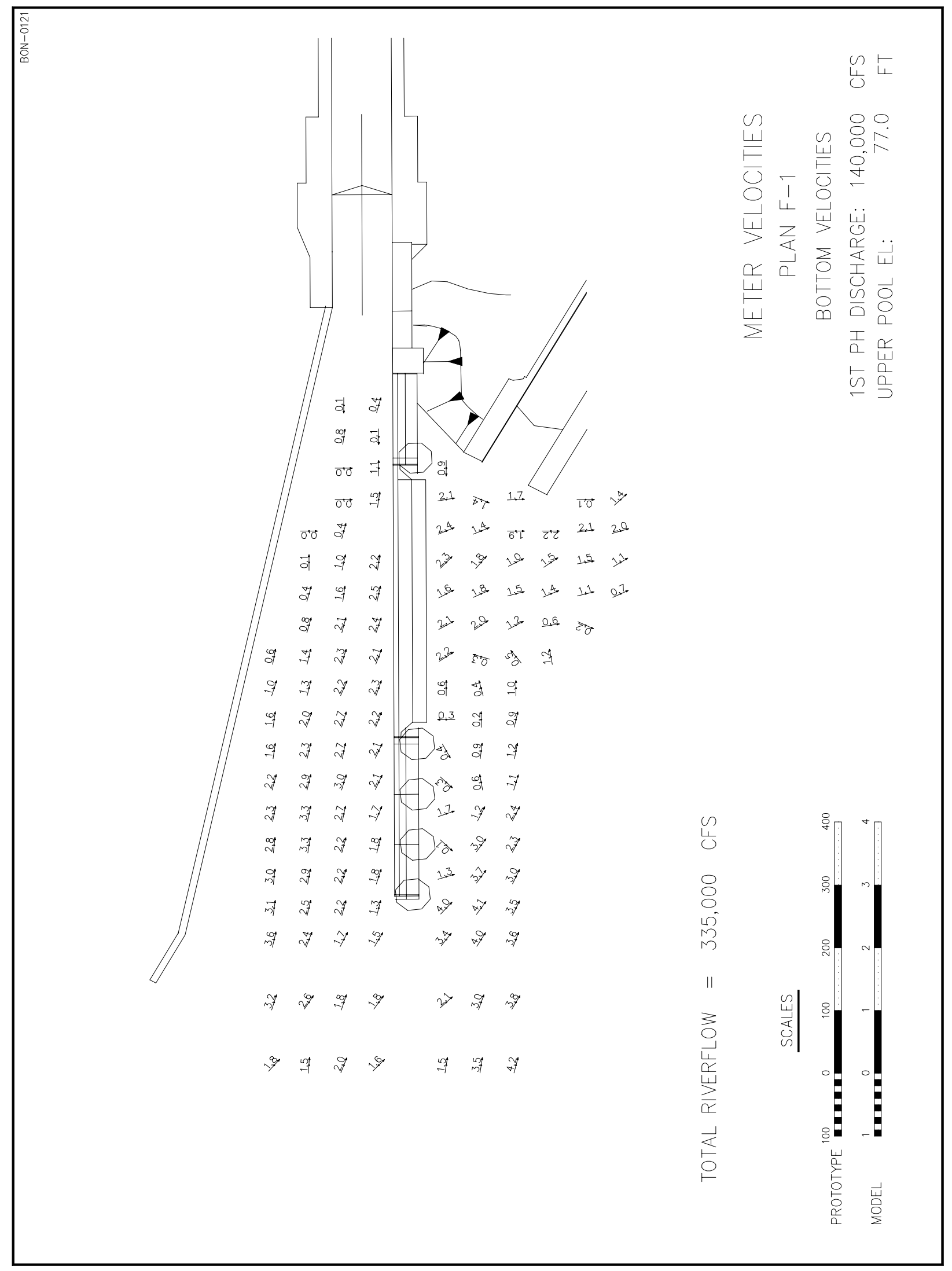

Plate 126 


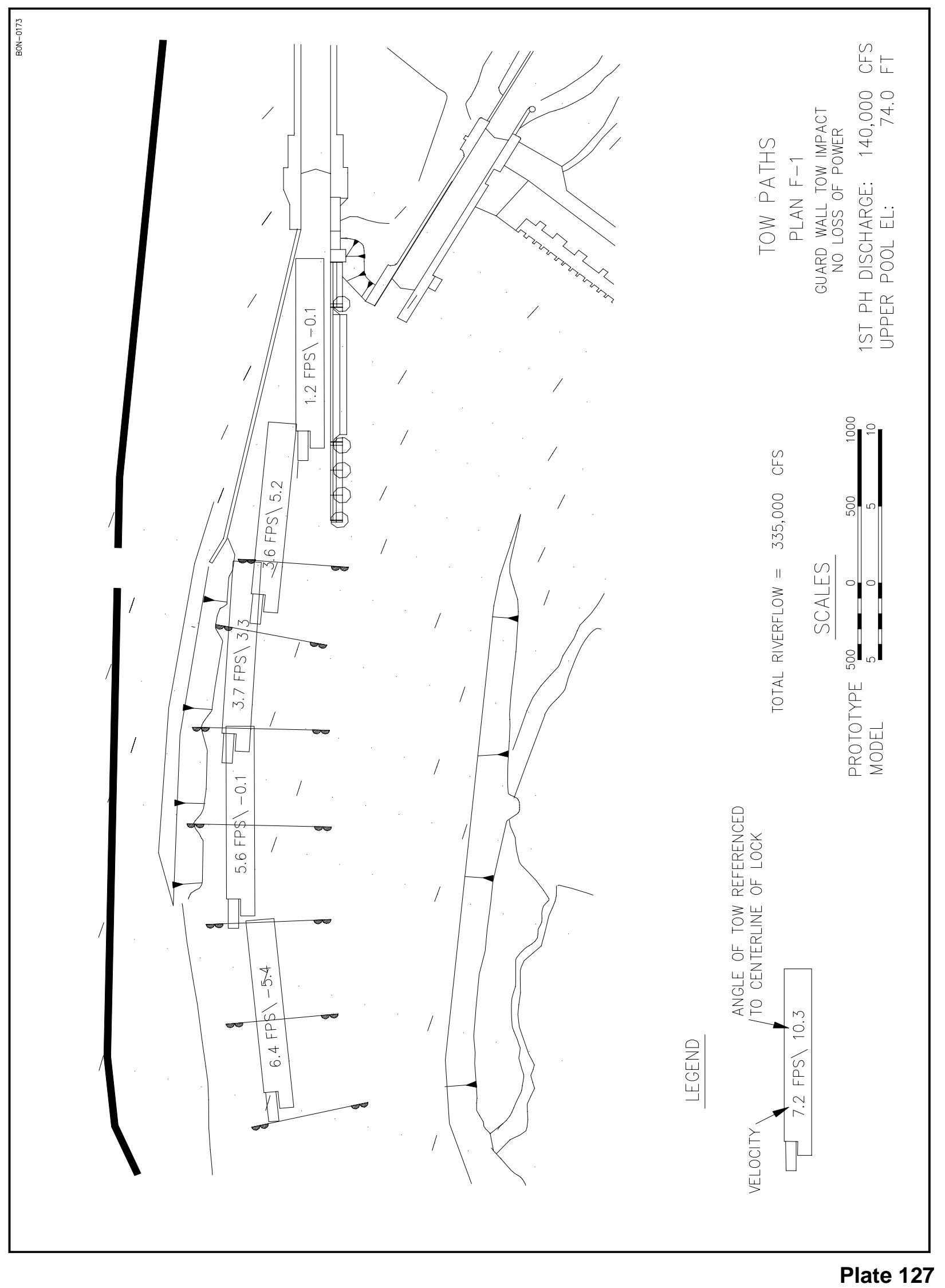




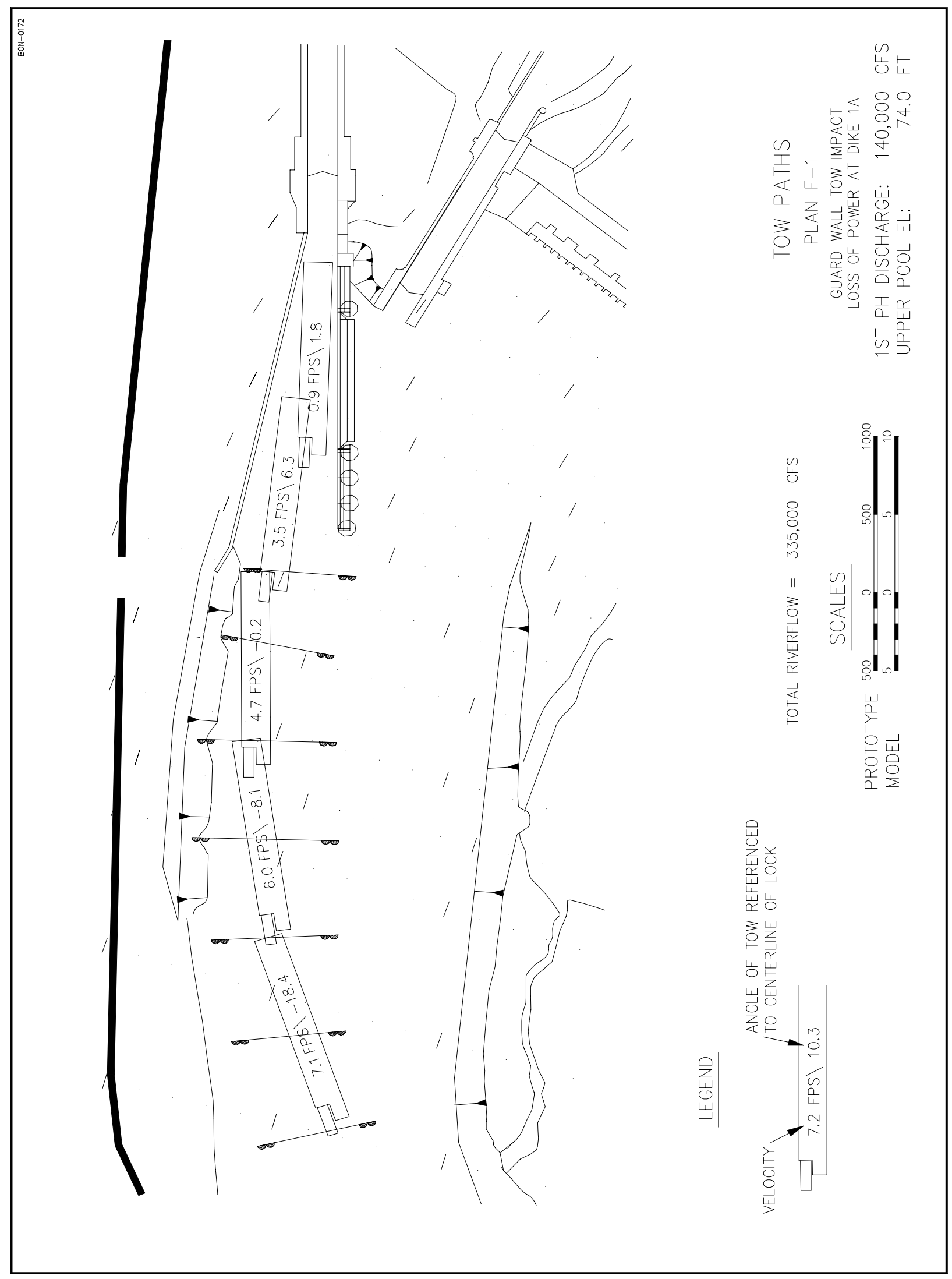

Plate 128 


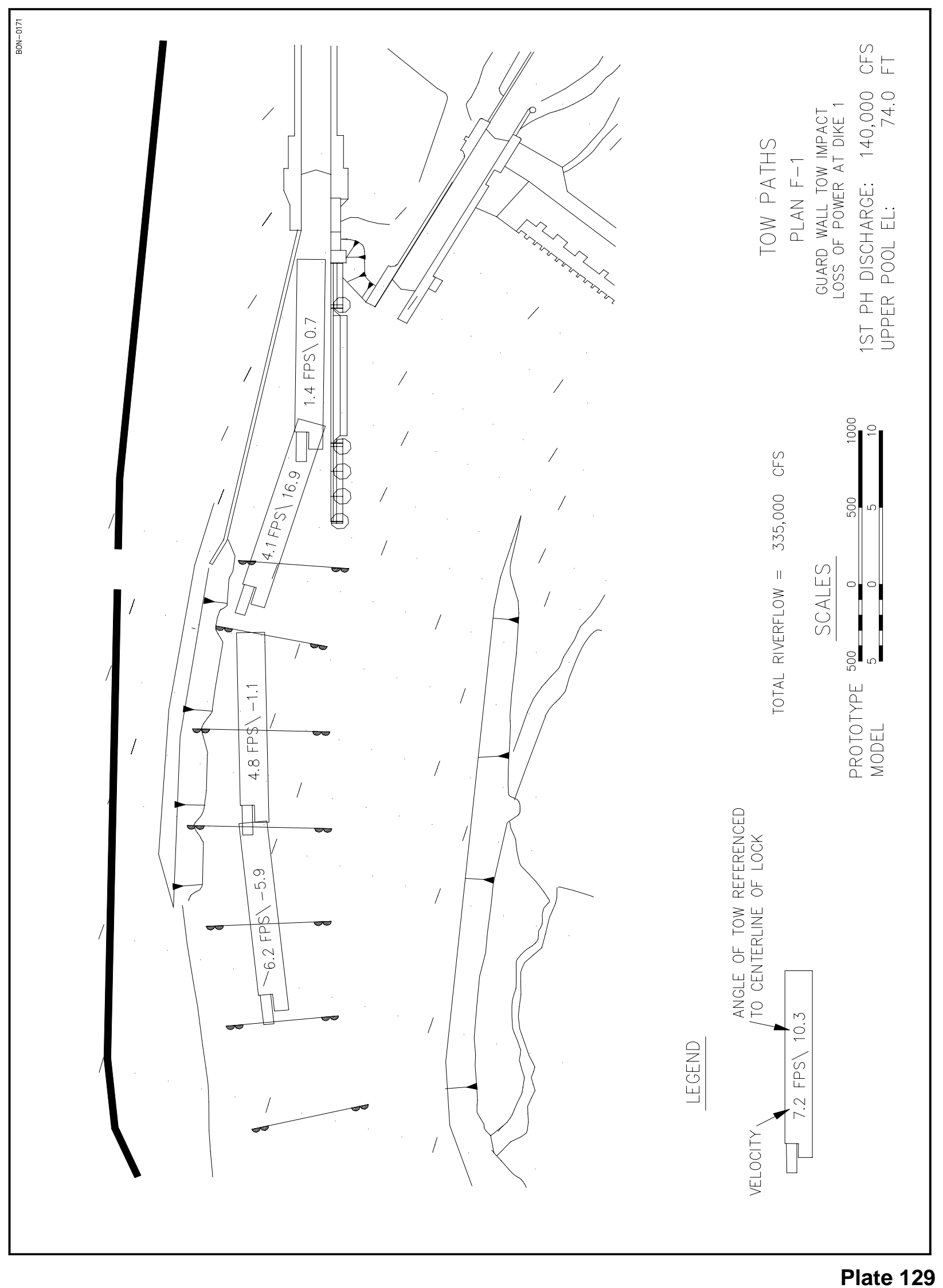




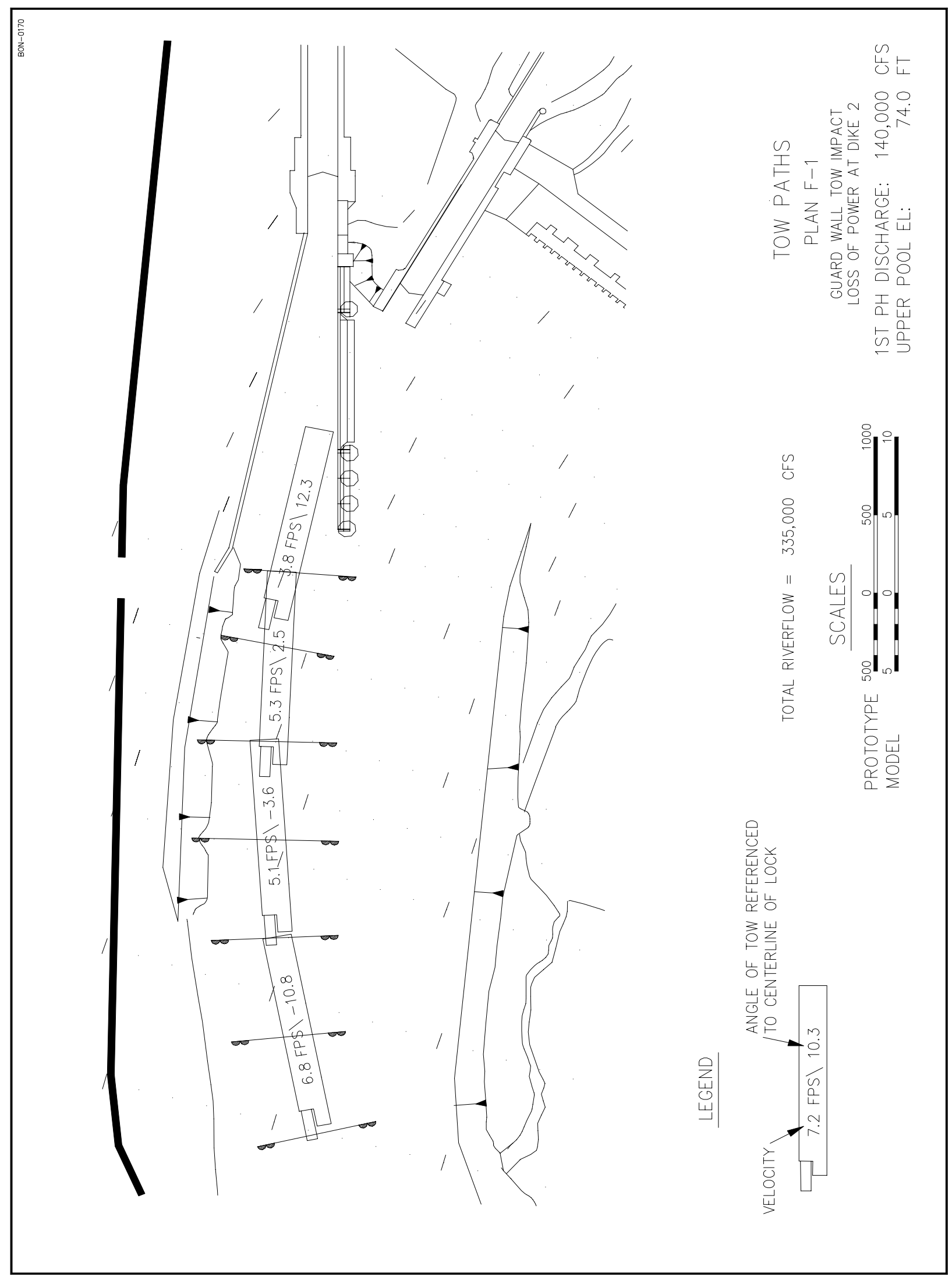

Plate 130 


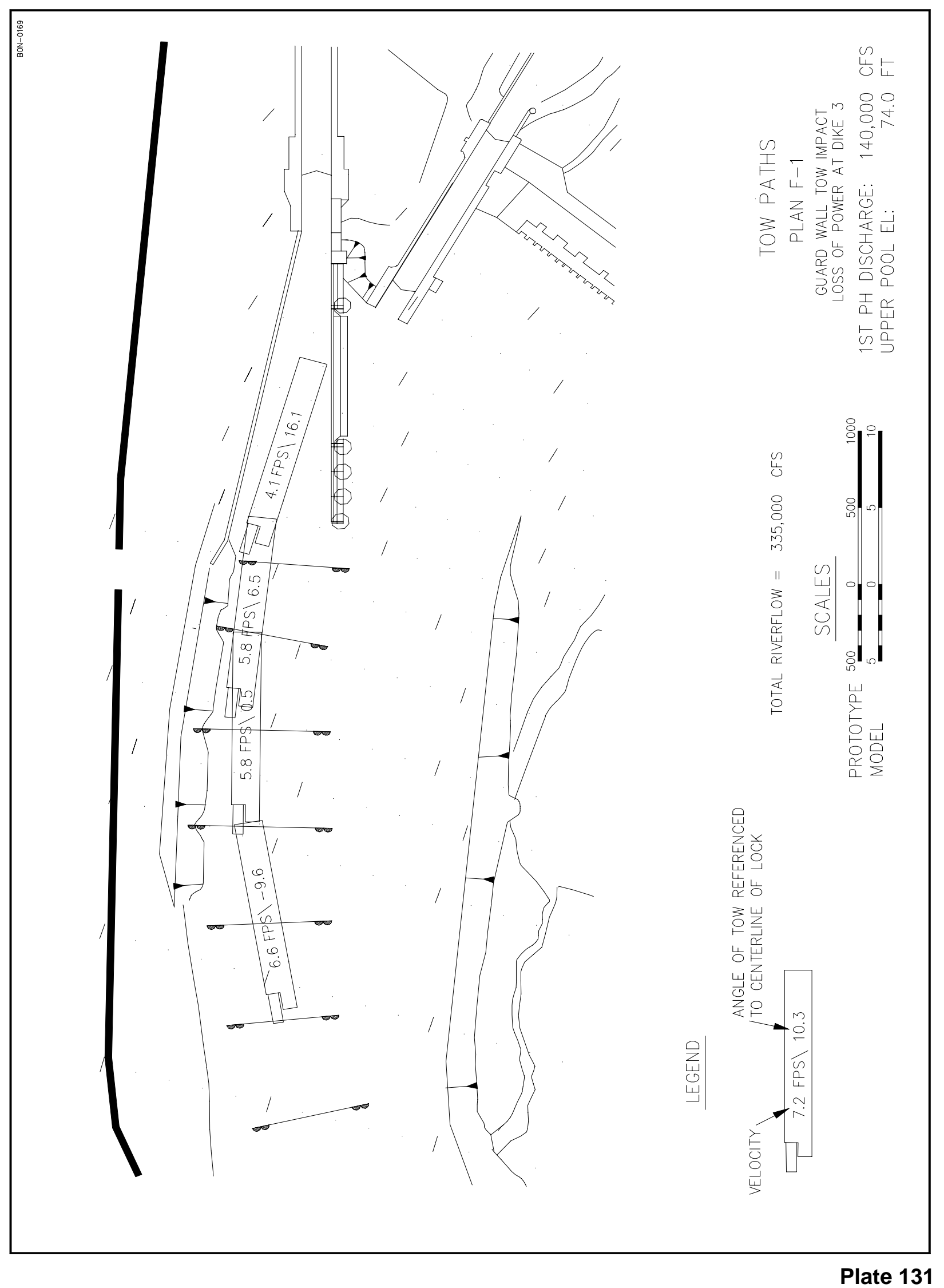




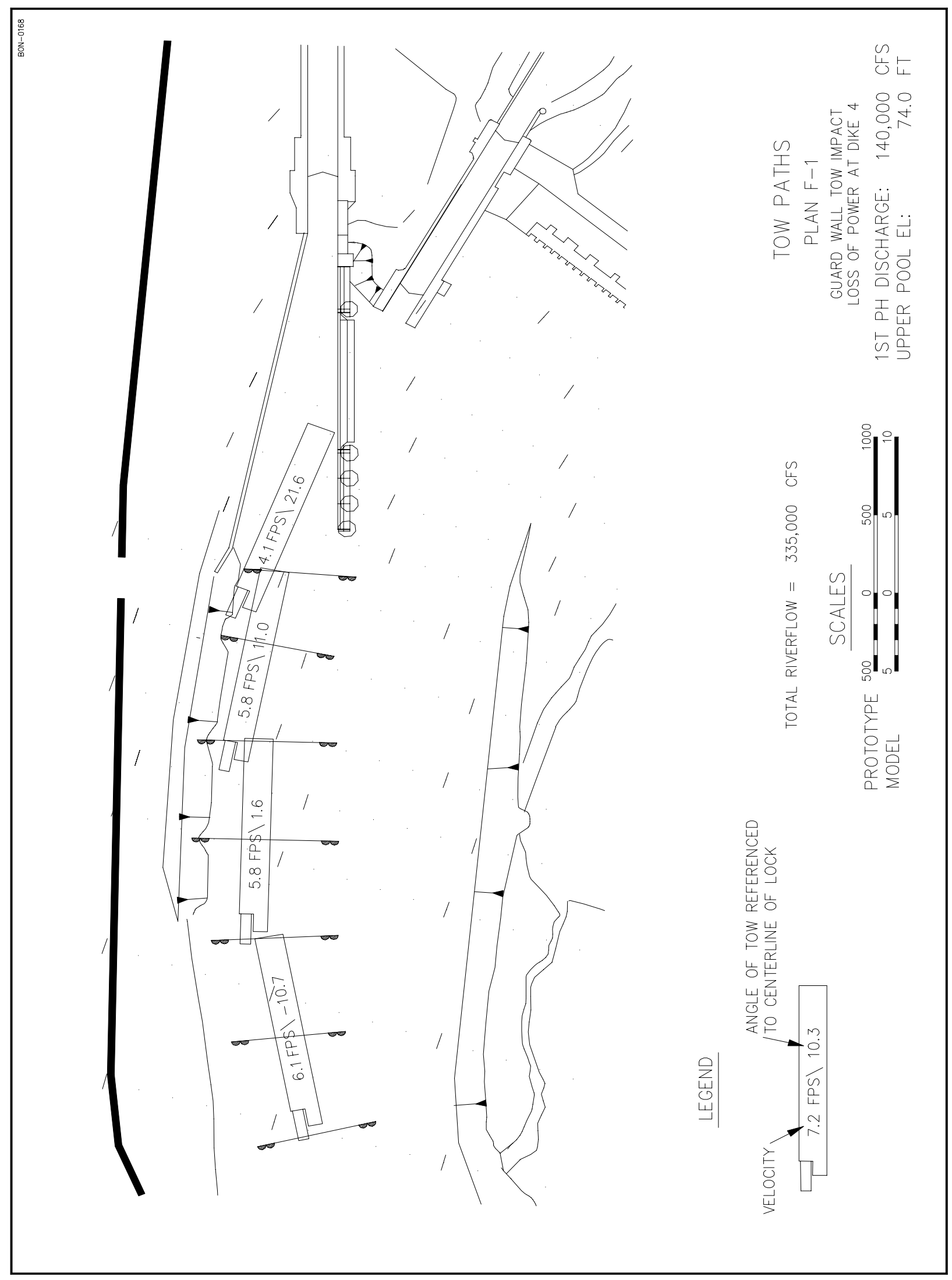

Plate 132 


$$
4
$$




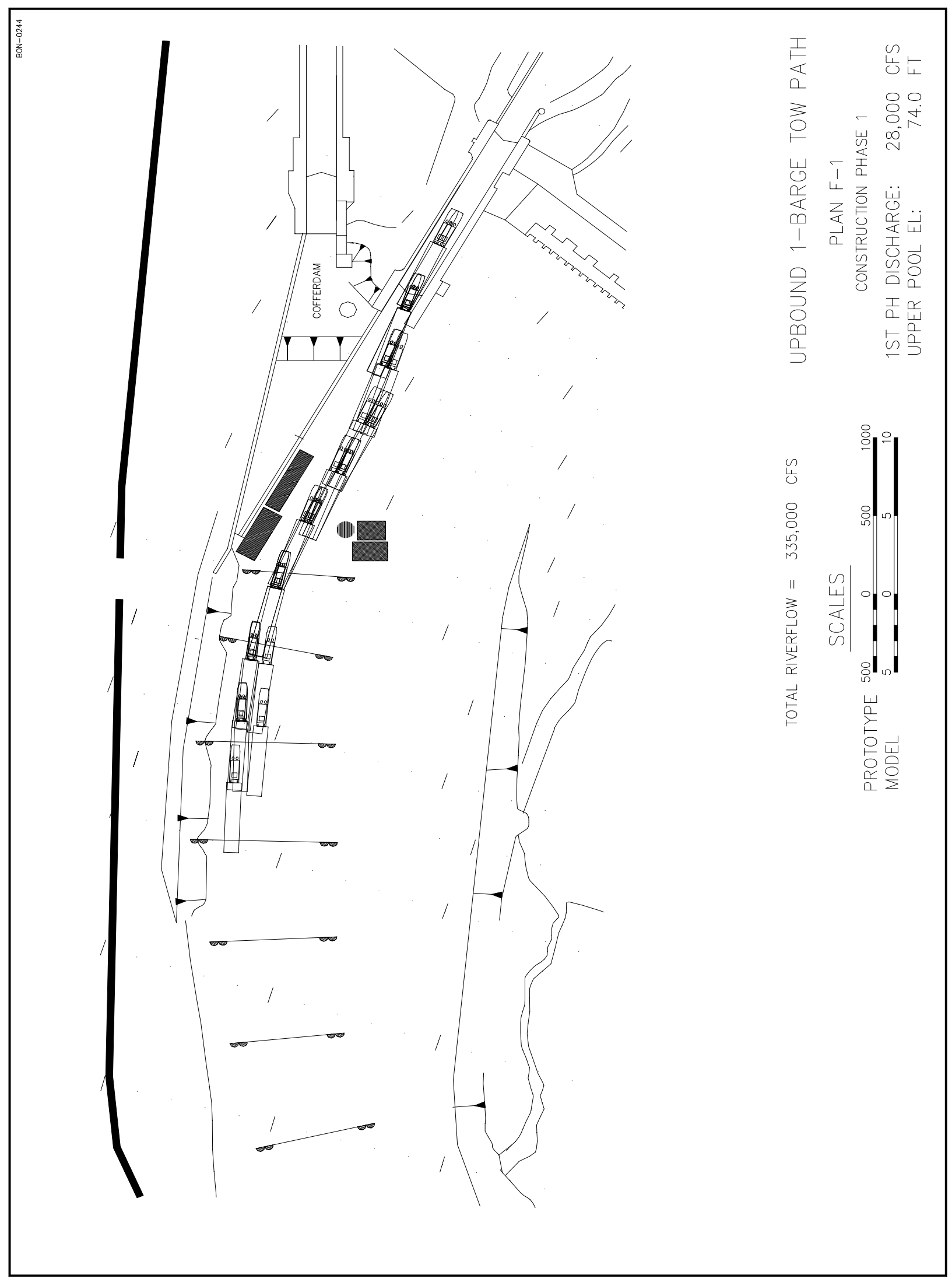

Plate 134 


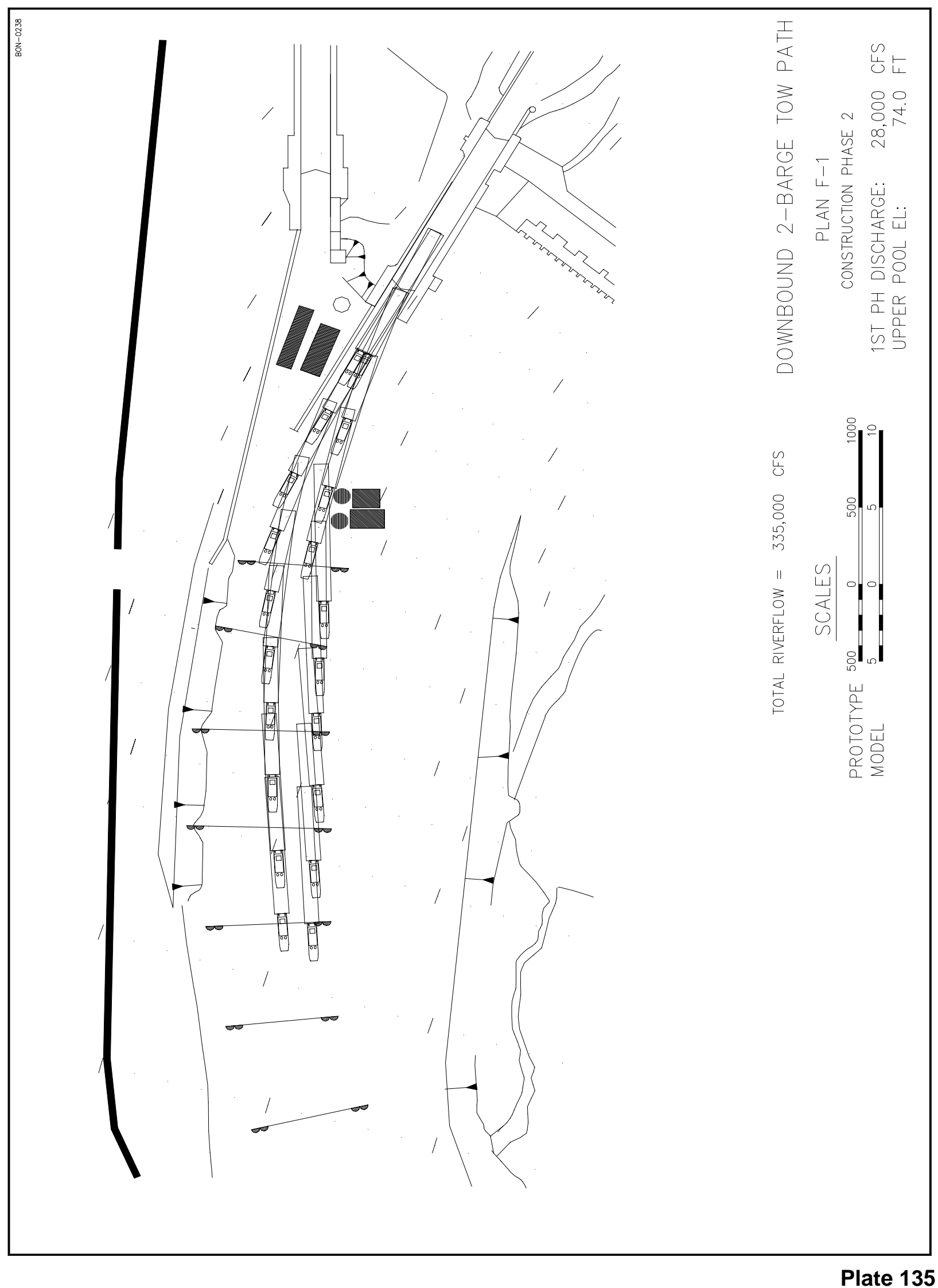




$$
1 \%
$$




$$
10
$$




$$
16
$$




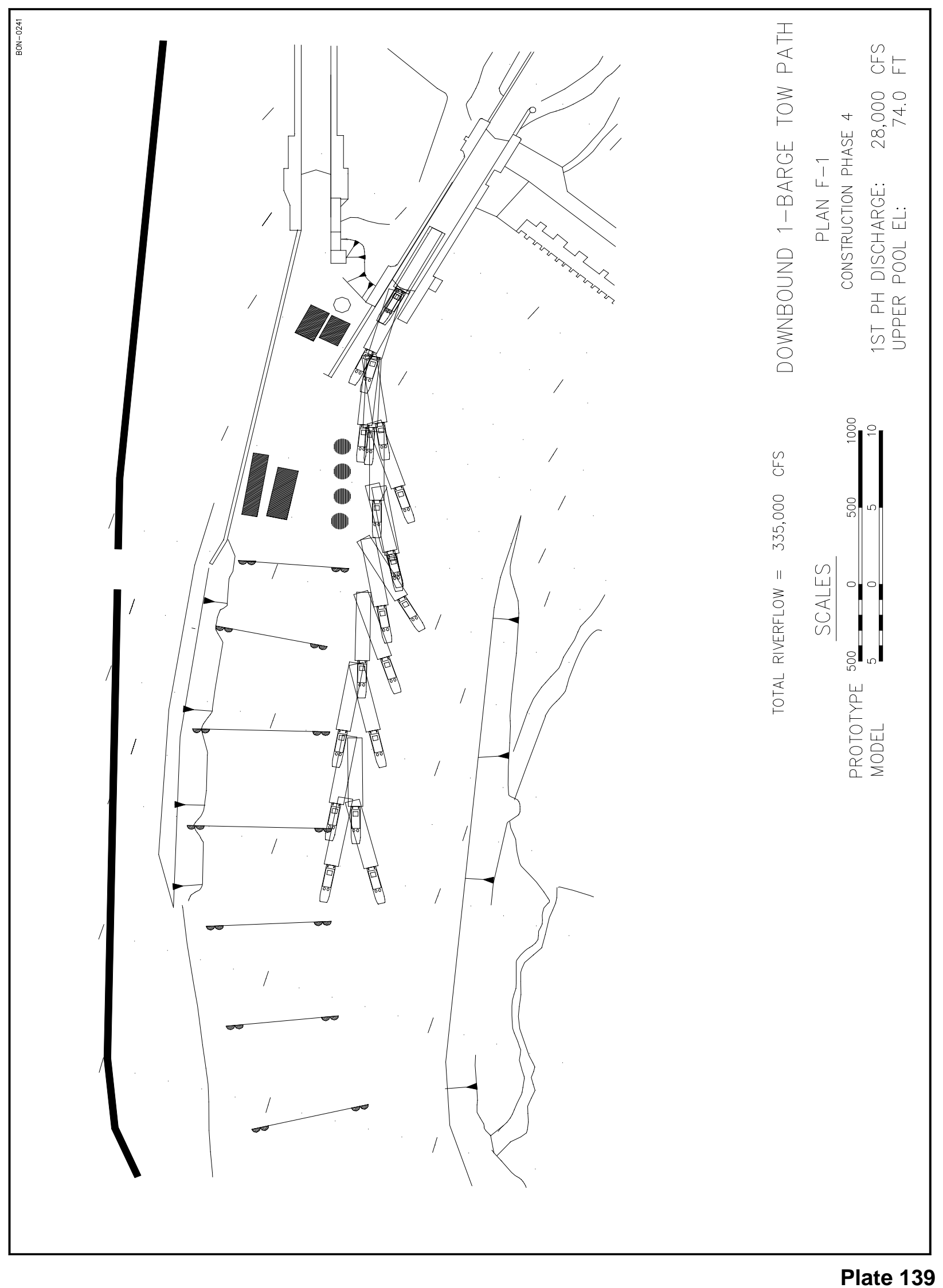




$$
10
$$




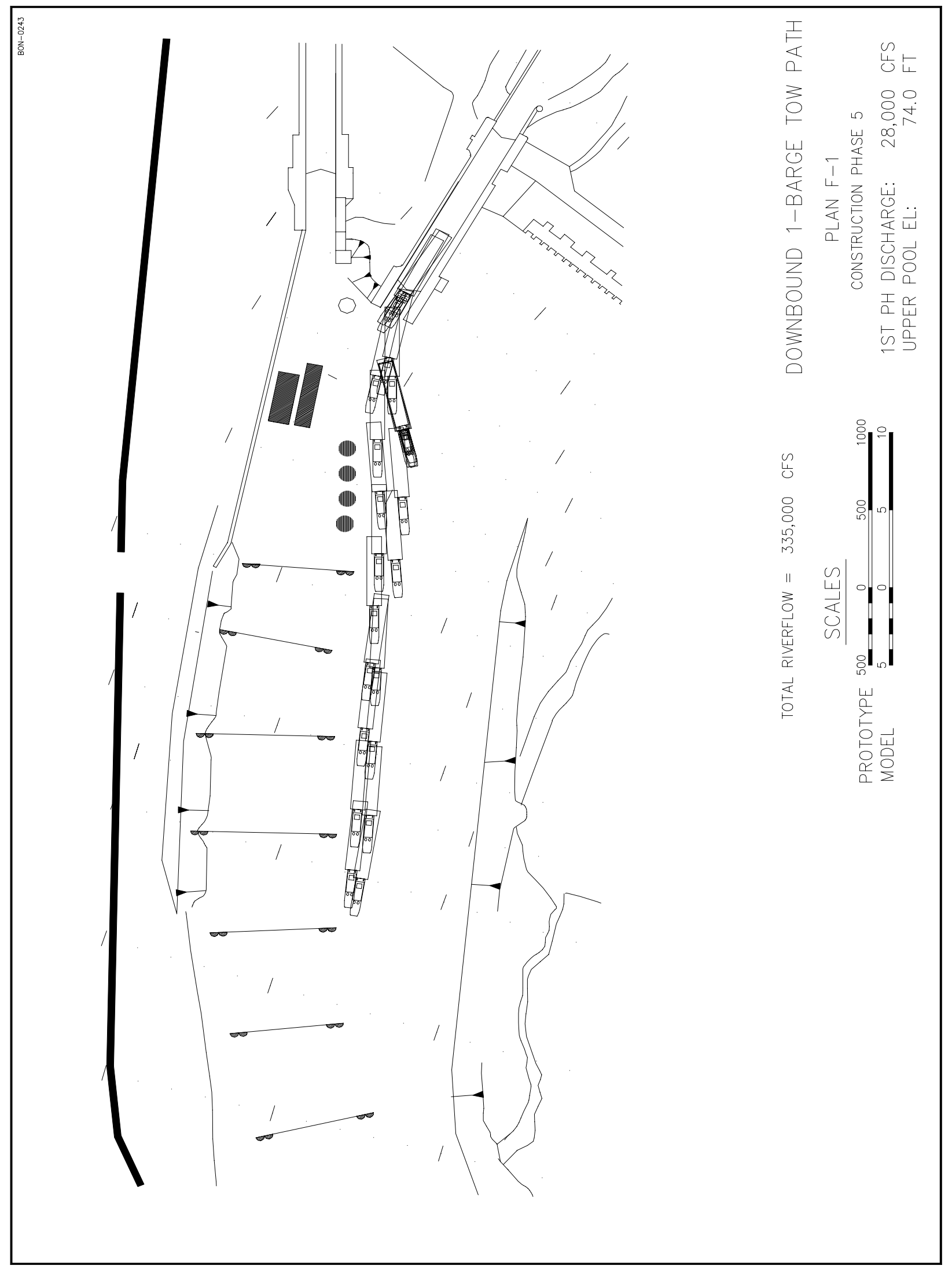

Plate 141 


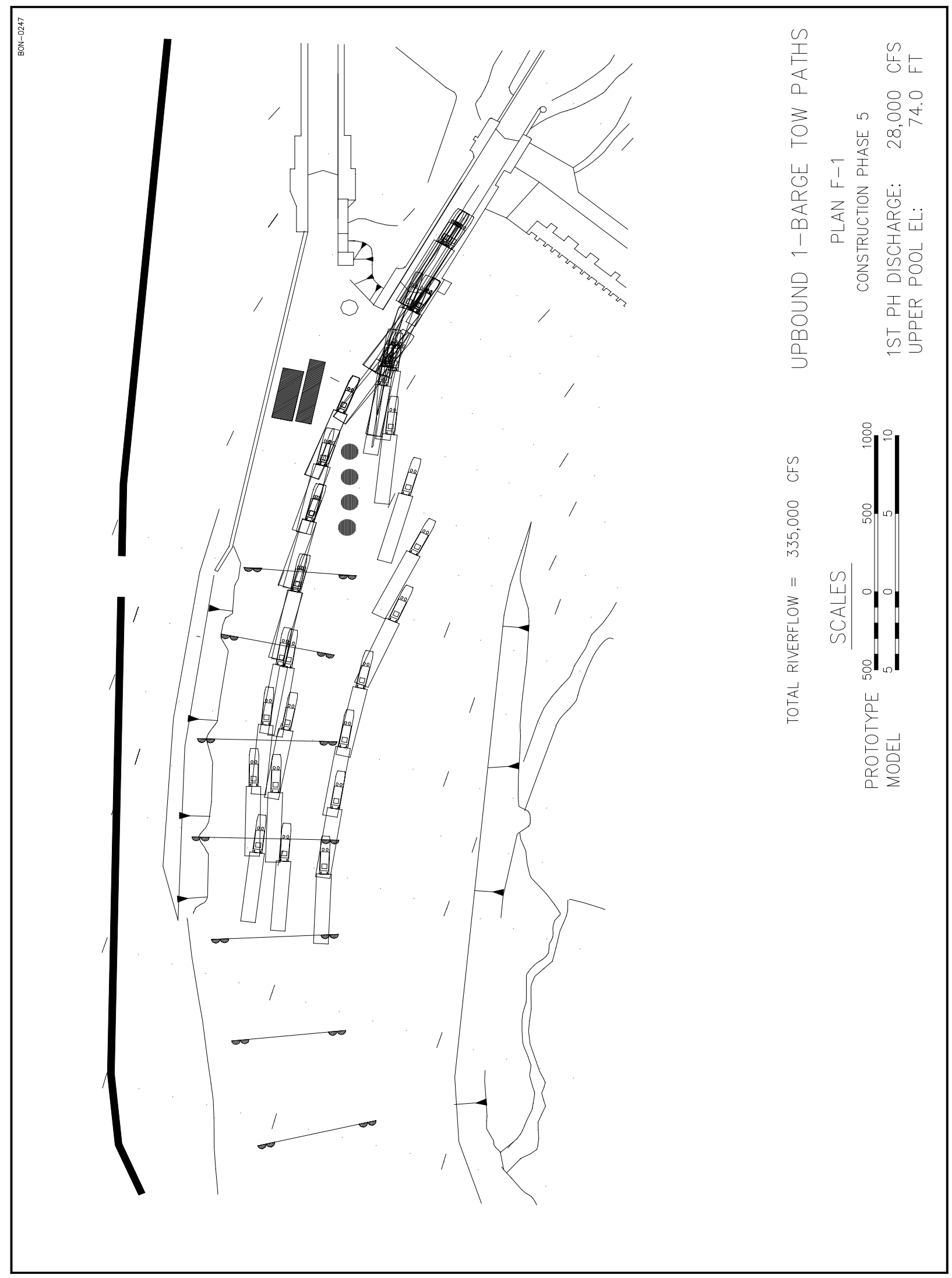

Plate 142 


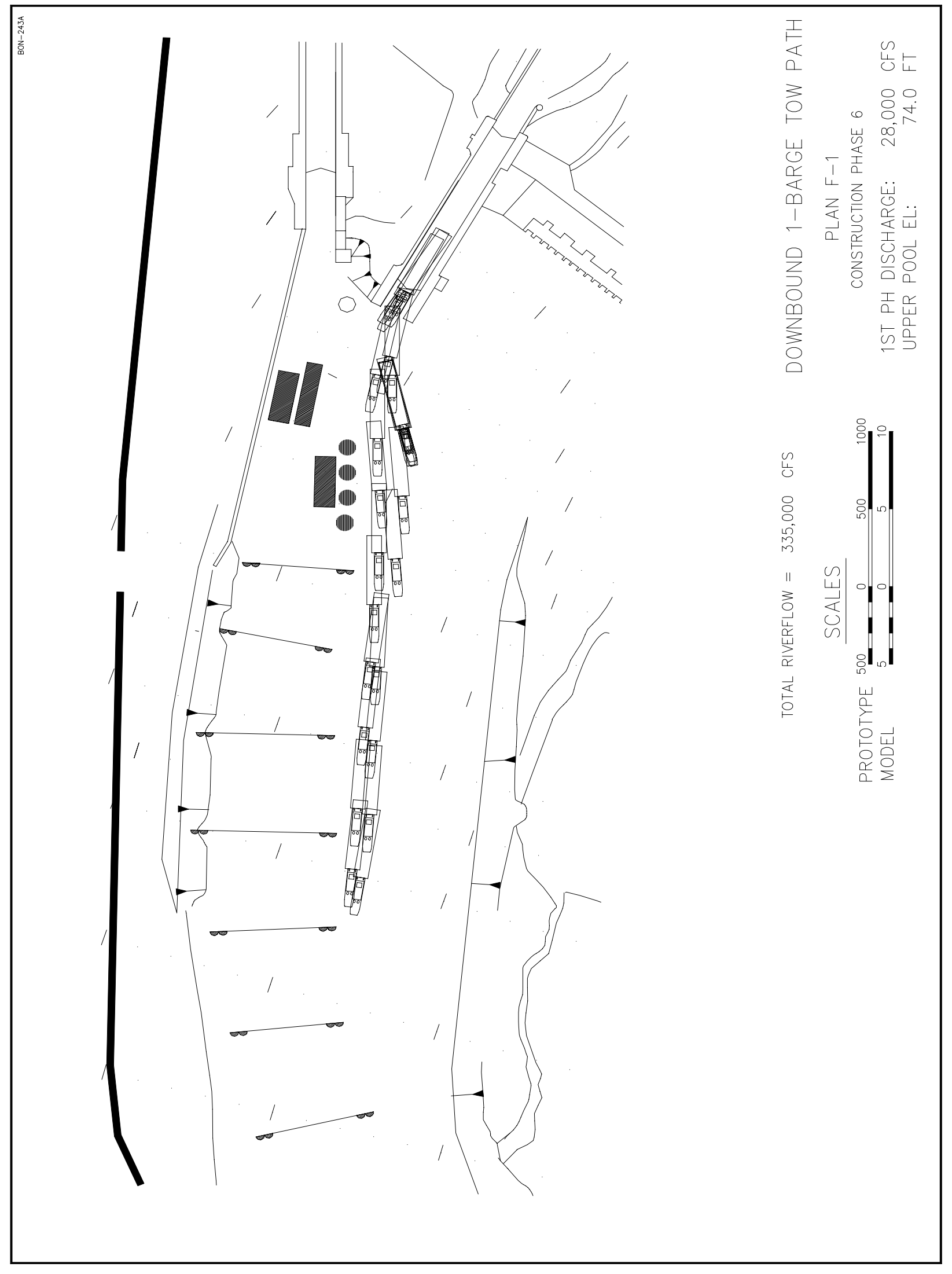

Plate 143 


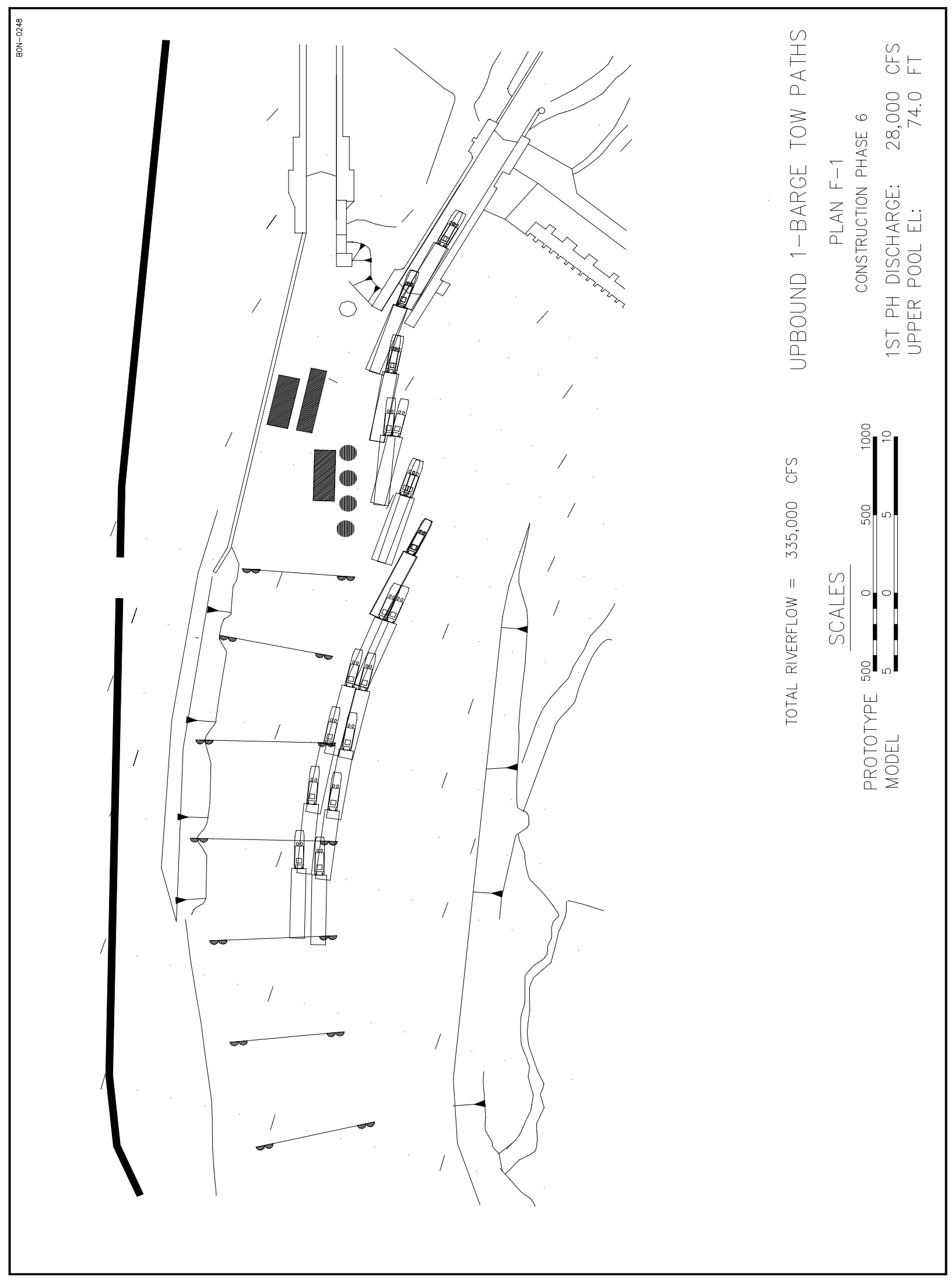

Plate 144 


\section{REPORT DOCUMENTATION PAGE}

Public reporting burden for this collection of information is estimated to average 1 hour per response, including the time for reviewing instructions, searching existing data sources, gathering and maintaining the data needed, and completing and reviewing the collection of information. Send comments regarding this burden estimate or any other aspect of this collection of information, including suggestions

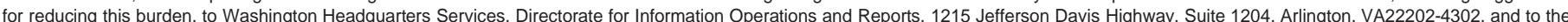
Office of Management and Budget, Paperwork Reduction Project (0704-0188), Washington, DC20503.

\begin{tabular}{|l|c|c|}
\hline 1.AGENCY USE ONLY (Leave blank) & $\begin{array}{c}\text { 2.REPORT DATE } \\
\text { February } 1998\end{array}$ & $\begin{array}{c}\text { 3.REPORT TYPE AND DATES COVERED } \\
\text { Final report }\end{array}$ \\
\hline
\end{tabular}

4.TITLE AND SUBTITLE

5.FUNDING NUMBERS

Navigation Conditions at Bonneville Locks and Dam,

Columbia River

6.AUTHOR(S)

Ronald T. Wooley

7.PERFORMING ORGANIZATION NAME(S) AND ADDRESS(ES)

U.S. Army Engineer Waterways Experiment Station

3909 Halls Ferry Road, Vicksburg, MS 39180-6199

8.PERFORMING ORGANIZATION REPORT NUMBER

Technical Report CHL-98-6
9.SPONSORING/MONITORING AGENCY NAME(S) AND ADDRESS(ES)

U.S. Army Engineer District, Portland

P.O. Box 2946

Portland, OR 97208-2946
10.SPONSORING/MONITORING AGENCY REPORT NUMBER

\section{SUPPLEMENTARY NOTES}

Available from National Technical Information Service, 5285 Port Royal Road, Springfield, VA 22161.

12a.DISTRIBUTION/AVAILABILITY STATEMENT

12b.DISTRIBUTION CODE

Approved for public release; distribution is unlimited.

13.ABSTRACT (Maximum 200 words)

The navigation system currently in use at Bonneville Locks and Dam, Columbia River, was placed in operation in May 1943. Navigation problems have resulted in damage to the guide wall and the wing wall of the lock. A new 86-ft-wide by 675 -ft-long lock has been proposed for construction immediately south of the existing lock. It was recognized that major channel modification s could be necessary to develop satisfactory navigation conditions for tows using the new lock. This report documents a comprehensive model study that was conducted to investigate conditions that could be expected with the proposed design and to develop the modifications required to ensure satisfactory navigation conditions. The effects of various plans and modifications on water-surface elevations and current directions and velocities were studied, as were the effects of the resulting currents on model towboat and tow behavior.

\section{SUBJECT TERMS}

Bonneville Locks and Dam

Columbia River

Current direction
Current velocity

Navigation conditions

Water-surface elevations
15.NUMBER OF PAGES

207

16.PRICE CODE

20.LIMITATION OF ABSTRACT OF ABSTRACT

\section{SECURITY CLASSIFICATION OF REPORT}

UNCLASSIFIED

\section{SECURITY CLASSIFICATION OF THIS PAGE}

UNCLASSIFIED

NSN 7540-01-280-5500

Standard Form 298 (Rev. 2-89)

Prescribed by ANSI Std. Z39-18 298-102 